UNIVERSIDADE DE SÃO PAULO

INSTITUTO DE PSICOLOGIA

PROGRAMA DE PÓS-GRADUAÇÃO EM PSICOLOGIA ESCOLAR E DO

DESENVOLVIMENTO HUMANO

\author{
Aline Costa Carrenho
}

ARTE, EDUCAÇÃO MUSICAL E FORMAÇÃO CULTURAL NO CONTEXTO DAS ORGANIZAÇÕES SOCIAIS: A PRÁXIS CULTURAL E SUAS CONTRADIÇÕES À LUZ DA TEORIA CRÍTICA

SÃO PAULO

2019 
ALINE COSTA CARRENHO

\section{ARTE, EDUCAÇÃO MUSICAL E FORMAÇÃO CULTURAL NO CONTEXTO DAS ORGANIZAÇÕES SOCIAIS: A PRÁXIS CULTURAL E SUAS CONTRADIÇÕES À LUZ DA TEORIA CRÍTICA}

Dissertação de mestrado apresentada ao Programa de PósGraduação em Psicologia Escolar e do Desenvolvimento Humano da Universidade de São Paulo, para a obtenção do título de Mestre em Psicologia.

Orientador: Prof. Dr. Pedro Fernando da Silva

SÃO PAULO

2019 
AUTORIZO A REPRODUÇÃO E DIVULGAÇÃO TOTAL OU PARCIAL DESTE TRABALHO, POR QUALQUER MEIO CONVENCIONAL OU EILETRONICO,

PARA FINS DE ESTUDO E PESQUTSA, DESDE QUE CTTADA A FONIE.

Catalogação na publicação Biblioteca Dante Moreira Leite

Instituto de Psicologia da Universidade de São Paulo

Dados formecidos pelo(a) autor(a)

Carrenho, Aline Costa

Arte, educação musical e formação cultural no contexto das organizações sociais:

práxis cultural e suas contradições à luz da Teoria Crítica / Aline Costa Carrenho;

orientador Pedro Fernando da Silva. - São Paulo, 2019.

$239 \mathrm{f}$.

Dissertação (Mestrado - Programa de Pós-Graduação em Neurociências e

Comportamento) - Instituto de Psicologia, Universidade de São Paulo, 2019.

1. Arte. 2. Educação musical. 3. Formação cultural. 4. Organizações sociais. 5. Teqnia Crítica. I. Silva, Pedro Femando da, orient II. Título. 


\section{DEDICATÓRIA}

Dedico este trabalho a todas as mulheres, mães e pesquisadoras acadêmicas, histórias de amor, luta e perseverança; ao meu filho, Iuri Miguel, a quem me apresentou a cura pelo amor e um recomeço; e aos meus ancestrais do sertão nordestino, histórias esquecidas de força, simplicidade e desolação. 


\section{AGRADECIMENTOS}

A Deus, pela sua imensidão que me criou, que me acolhe e abraça nos tempos de aflição, que me cuida e me cura com Amor, que me espera pacientemente acordar do sono das ilusões e das pequenezas infladas da vida matéria, por abrir em meu peito uma morada sua: de Vida, de Alegria, de Saúde e de Renascer em Amor.

Ao meu esposo, Vinícius, sem a sua inestimável presença, companheirismo e tantos esforços somados, eu não teria conseguido concluir tamanho compromisso. Obrigada por respeitar minhas escolhas e por sacrificar muitas vezes as suas para eu poder ser mãe e uma aprendiz de pesquisar, para eu poder assistir às aulas na pós-graduação e amamentar o nosso filho, coisas tão simples aos olhos alheios, mas que exigiram muito de você nos bastidores da nossa vida cotidiana nesses últimos anos. Obrigada pelo encorajamento e pelos abraços doces nos dias de meus desesperos, pelo nosso amor que amadurece e por escolher caminhar sua vida junto com a minha.

Ao Theodor Adorno, pelo comprometimento ético para com o conhecimento, pela sua “teimosia em dizer o indizível” e, por fim, pela persistência quanto à necessidade da crítica permanente. Que seu percurso teórico e, por assim dizer, sua práxis, é responsável por parte significativa do início do meu próprio e doloroso processo de desbarbarização.

Aos professores que tive a oportunidade de conhecer durante a minha graduação em psicologia, por aula a aula, pela convivência durante reuniões, grupos de estudos, grupos de trabalho de cultura e extensão e pela introdução à pesquisa, muito me ensinaram: mais que conhecimentos formais, a ética de ser, de estudar, de conviver, de investigar. Deixo aqui meu terno agradecimento principalmente aos professores e professoras José Leon Crochik, Adriana Marcondes Machado, Paulo Albertini e à Leny Sato.

Ao meu professor orientador, Pedro Fernando da Silva, que esteve solícito e que foi compreensível às minhas provações e descobertas da minha vida particular. Agradeço pela paciência, pelo respeito, pela empatia, pela caminhada conjunta para um novo conceito de esclarecimento e pelas orientações nesse meio-tempo.

Aos meus familiares e, em especial, à minha mãe, por me ajudar a iniciar a minha própria caminhada por mais que, para isso, a sua já estivesse tão cheia de fardos pesados. 
À minha sogra Maria Celeste e ao meu sogro Agnelo por sempre se fazerem tão disponíveis neste momento, por toda ajuda oferecida e por toda amabilidade. Sem vocês, talvez não teria conseguido.

À Dedê, pelo carinho que me cuida e me abraça sempre e me faz sentir tão bem em sua companhia.

Ao meu txai, Guilherme, pela amizade fraterna.

Aos meus queridos amigos Gian, Lucas e Marcos pela amizade desde os tempos de graduação, pela atenção e pela disposição genuína em revisar meu texto de dissertação.

À minha querida amiga Gabriela Milaré pela sensibilidade, pelo carinho, pela presença contínua e pelo cuidado que teve comigo. De grande importância foram os nossos encontros, cafés, conversas, abraços, risos e lágrimas, pudemos compartilhar e crescer juntas nesse caminho de aprender acadêmico, e muito criticá-lo.

Aos meus colegas de trabalho, o grupo de orientandos, que tive a oportunidade de conhecer. Agradeço pela sensibilidade, pelas importantes trocas, pelo apoio e suporte que recebi de todos vocês. Em especial, à Jéssica Ochoa, pela disponibilidade amável.

À minha mana Letícia, fada encantada, pela amizade verdadeira e cheia de ternura.

À Ana Fiori, amiga de embarcação do astral, por me acolher em meus anseios e me ajudar a seguir em frente.

Ao mestre Sombra e aos meus mais novos colegas de capoeira, pelo acolhimento respeitoso, pelas rodas de berimbau e pelas cantigas de berço. Com vocês, me sinto à vontade de ser minhas alegrias e tristezas, as virtudes e as fraquezas.

À Sandra e à Olívia, secretárias da graduação e da pós-graduação pelo departamento do PSA, por todo o significativo auxílio burocrático e informativo, pois sem vocês nem teria concluído o curso do mestrado, possivelmente, já teria sido excluída do programa por não ter lembrado dos prazos exatos das inúmeras matrículas, inscrições e preenchimentos de formulários, necessários para a minha permanência e continuidade na pós-graduação. Mas agradeço ainda mais pelo acolhimento sensível.

Ao projeto social e aos participantes da pesquisa empírica: alunos, professores e dirigência, pelo voto de confiança, pela agradável receptividade, pelas trocas e pelos encontros. Obrigada por conhecer uma linda escola de música com aconchego de casa de vó cantante! Obrigada por tanto me mostrarem. 


\section{RESUMO}

A proposta desta pesquisa empírica foi a de desenvolver uma investigação sobre a práxis cultural das organizações sociais e, mais especificamente, de projetos socioeducativos e culturais localizados em áreas de bolsões de pobreza e de desigualdades sociais, como as periferias das grandes cidades brasileiras. A atuação das mais diversas organizações sociais está diretamente relacionada às realidades sociais agravadas pelas situações generalizadas de desigualdades e vulnerabilidades sociais, pela violação de direitos universais, bem como pelo preconceito, estigmas sociais, pela violência e pela exclusão social. Nesse contexto de atuação, a arte, a cultura e a educação estética são usualmente compreendidas como campos possíveis e potentes para a transformação social, já que são referenciadas pela sua potencialidade política de autonomia, de oposição ao todo social - seja pelo caráter de crítica social, seja pela formação da consciência humana. Frente a isso, buscou-se nesta pesquisa desenvolver uma análise reflexiva e crítica sobre esse tipo de práxis e suas contradições a partir da compreensão teórica conceitual da Teoria Crítica da Sociedade, em especial, das caras contribuições de Theodor Adorno concernentes ao campo da fenomenologia social e psicológica da arte, da educação musical e da

formação cultural. E tendo-se em vista um dos pontos nevrálgicos do pensamento dialético, a relação entre o todo e o particular, e o fato de o objeto de estudo compreender um contexto da realidade contemporânea, buscou-se pensar sobre o tipo de relação estabelecida com a arte, com a cultura e com a educação no contexto das tendências organizativas dessas coletividades, por vezes institucionalizadas, em confronto reflexivo com uma escola de música situada na extrema zona sul da cidade de São Paulo e que presta serviço ao público infanto juvenil dessa região, como representação de uma unidade concreta da práxis cultural em questão. De acordo com os resultados obtidos, as potencialidades criativas humanas relacionadas à arte, cultura e à educação musical foram reunidas muitas vezes em conceitos a-históricos, como denominadores comuns neutros, e, deste modo, compreendidas por uma perspectiva ingênua de que as palavras correspondentes por si só, como fórmulas mágicas, são garantias certas e fixadas da efetivação daquilo que se intenta subjetivamente. Foi identificado nos discursos de movimentos e coletivos culturais da região mapeada, bem como de projetos socioculturais e educativos, uma justaposição entre aquilo que se objetiva realizar e aquilo que é de fato produzido, o que marca uma significativa e preocupante questão ao que diz respeito aos conceitos utilizados, aos sentidos e 
finalidades de sua práxis e à qualidade de organização da mesma, no que se refere à sua consistência e objetividade no sentido de haver comprometimento com as leis formais da arte autônoma, bem como de prover condições objetivas para uma educação emancipatória e para a formação cultural. Contudo, foram observadas sérias contradições na interioridade da própria práxis engajada: o empobrecimento do material estético; a presença da racionalidade técnicaadministrativa, racionalidade da própria dominação social; ausência de relação reflexiva entre teoria e práxis e ausência de autocrítica. Faz-se emergencial, pois, pensar a própria práxis cultural.

Palavras-chave: Arte; Educação Musical; Formação Cultural; Organizações Sociais; Teoria Crítica. 


\begin{abstract}
This empirical research proposition was to develop an investigation on the social organizations cultural praxis and, specifically, on socio-educational and cultural projects located on poverty and social iniquity dominant areas, such as peripheral zones in Brazilian large cities. The social organizations actions are directly related to the social reality aggravated by the generalized social iniquities and vulnerabilities, the universal rights violations, as by the prejudice, social stigmas, violence and social exclusion. In this context of actions, art, culture and aesthetic education are usually seen as possible and potent fields to social transformation since they are referenced by their political potential of autonomy and antagonism to the social whole - either by the social criticism characteristic, or by human consciousness formation. By this means, this research aimed a reflexive and critical analysis development about this kind of praxis and its contradictions from the theoretical conceptual comprehension of the Critical Theory of Society, in particular from Theodor Adorno's precious contributions concerning the social phenomenology and arts psychology fields, musical education and cultural formation. Taking into account one of the dialectical thinking neuralgic points, the relation between the whole and the particular and the fact that the contemporary reality is a part of the study object, it was sought to think about the kind of relationship established with art, culture and education in the context of the organizational trends of these collectivities, sometimes institutionalized, in reflexive confrontation with a musical school located in the extreme south zone of Sao Paulo city that serves the region's children and adolescent public as a representation of a concrete unit of the cultural praxis in question. According to the obtained results, the human creative potential related to arts, culture and musical education was oftentimes reunited in ahistorical concepts as neutral common denominators and, that way, understood by a naïve perspective that the corresponding words, by themselves and as magical formulas, are certain and fixed guarantees of the effectiveness of what is subjectively attempted. It was identified in the cultural collectives' speeches of the mapped region, such as educational and sociocultural projects, an overlap between what one intends to accomplish and what is actually accomplished, a fact that marks a significant and worrying issue regarding the used concepts, the senses and the purposes of the praxis and its organizational quality, with regard to its consistency and objectivity in the sense of commitment to the autonomous art's formal laws, as well as to provide objective conditions for emancipatory
\end{abstract}


education and cultural formation. However, serious contradictions were observed in the interiority of the engaged praxis itself: the impoverishment of aesthetical material; the presence of technical-administrative rationality, social domination's rationality itself; absence of a reflexive relation between theory and praxis and lack of self-criticism. It is therefore urgent to think the cultural praxis itself.

Keywords: Arts; Musical Education; Cultural Formation; Social Organizations; Critical Theory. 


\section{SUMÁRIO}

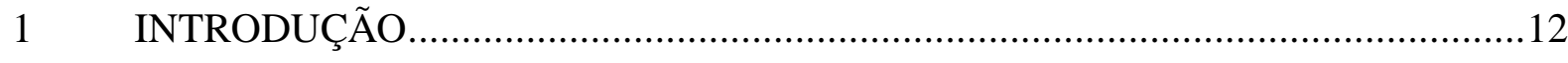

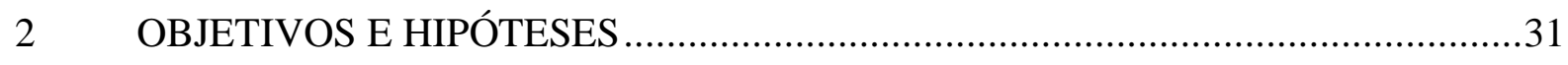

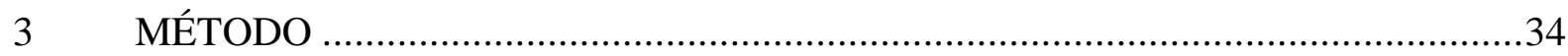

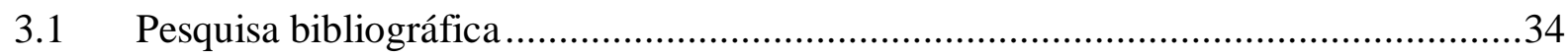

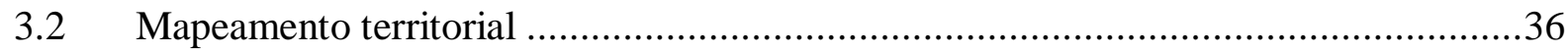

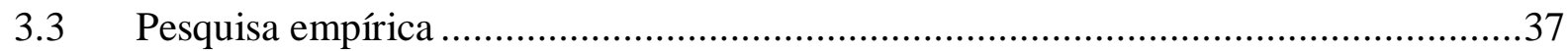

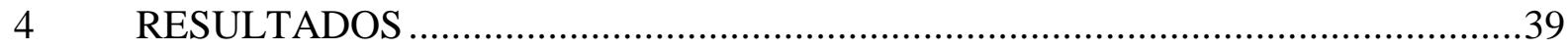

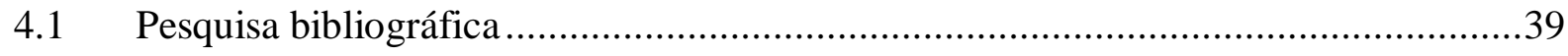

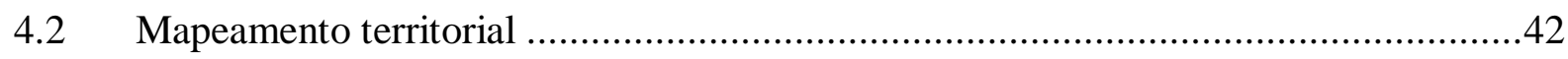

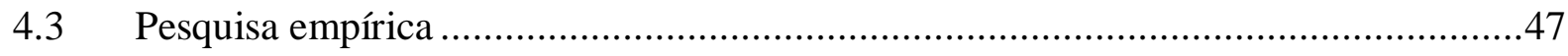

$5 \quad$ DISCUSSÃO

5.1 A periferia, as perspectivas estereotipadas e as desigualdades sociais.........................66

5.2 Estéticas marginais, resiliência e luta por reconhecimento: uma voz que ecoa............76

5.3 O funk e o rap como repertórios estéticos musicais da juventude periférica: entre estéticas

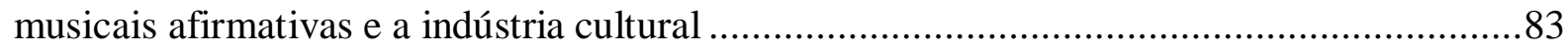

5.4 A arte engajada e a identidade cultural periférica: o risco do passo em falso ..............101

5.5 Acessibilidade ou democratização da cultura? ..........................................................127

5.6 A ambientação escolar, o direito universal e a consciência do próprio valor: um processo de socialização proponente para a formação de sujeitos? .....................................................135

5.7 As práticas das organizações socioculturais e educativas: práxis para a resiliência ou para

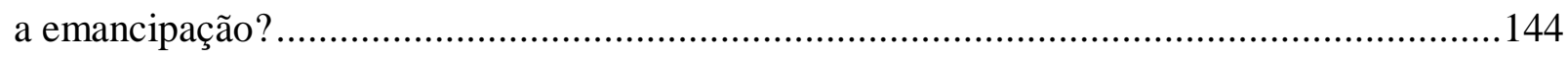

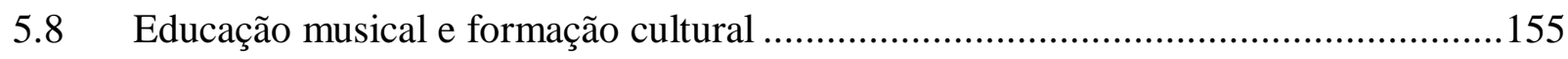

5.9 O papel do educador musical dentro do contexto de projetos sociais e a qualidade do planejamento político-pedagógico de suas propostas educativas ............................................177

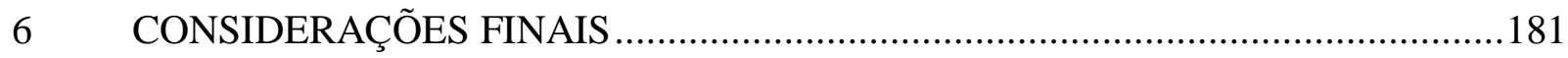




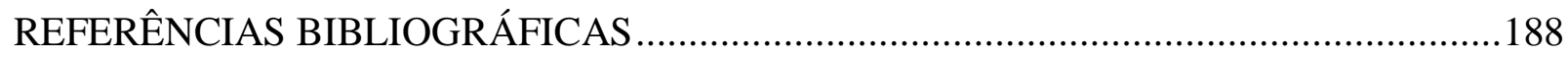

ANEXOS

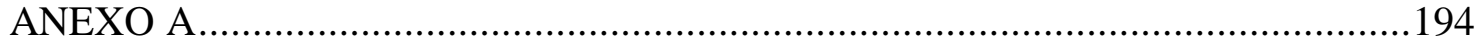

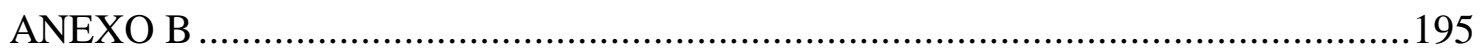

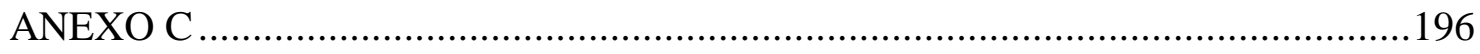

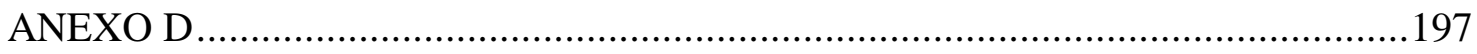

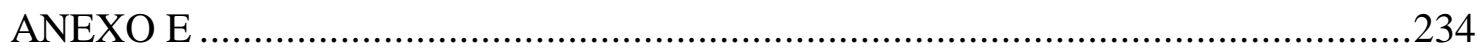




\section{INTRODUÇÃO}

A sociedade atual, resultado da dinâmica histórico-social, está organizada e estruturada pelos interesses do capitalismo tardio; a burguesia, por sua vez, se faz nascente antes dela própria, tendo-se Ulisses como o protótipo do indivíduo burguês (ADORNO; HORKHEIMER, 2006). Força dominante que determina as demais esferas de poder, de socialização e da (pseudo)formação cultural com fins, sobretudo, de manter e de expandir a si mesma, seus lucros e sua produção mercantil, ou seja, a benefício de uma pequena parcela da população. Os indivíduos, bem como a sua práxis criativa, tornam-se mercadoria e uma massa amorfa aos olhos da dominação social, é desumanizada por essa: a própria vida passa a ser administrada e coisificada a benefício dessa forma de socialização; o corpo torna-se domesticado e a consciência, alienada; a realidade passa a se constituir por um jogo de ilusões e de aparências, uma falsa vida, onde se vive em cárcere, sem sequer dar conta da própria cela que nos cerceia e nos impede de uma verdadeira liberdade (plena, prazerosa e emancipatória) (CROCHIK, 2001), pois também lhe foram tiradas as condições para a conscientização e para a individuação: a autonomia para se ir além do que está socialmente determinado, ao sempre-igual, à autoconservação.

Em decorrência, a cidadania, a igualdade social e os direitos humanos, enquanto esferas valorativas do ser humano como indivíduo autônomo, são rebaixadas aos domínios dos interesses econômicos autárquicos e de sua barbárie; assim como a educação, a arte e a cultura ficam sujeitas ao domínio totalitário e massificante da administração, reduzidas a bens de consumo (ADORNO, 2004), em detrimento da possibilidade de coexistência conciliada entre o todo social e as suas singularidades, e, assim sendo, a sua autonomia, espontaneidade e potencialidade reflexiva crítica: o que expressa a própria condição humana dominada, incapaz de autodeterminar-se, ou seja, incapaz de transpor a imagética da mera existência socialmente determinada. Isso porque lhes foram surrupiado o princípio do pensamento criador, restando-lhes, em troca, a razão dominante e os seus mecanismos sociológicos e psicológicos, os quais são introjetados heteronimamente, ou melhor dizendo, os mecanismos ideológicos da indústria cultural (ADORNO; HORKHEIMER, 2006). A arte, a educação e a cultura também apresentam em sua fenomenologia elementos da estrutura social da sua época, por mais que apresentem conteúdos de sua negação. De modo que, segundo Adorno (2004): 
Sin embargo, la administración no se le impone sólo desde fuera al ser humano supuestamente productivo. La administración se multiplica en él mismo. Que una situación temporal produce a los sujetos sintonizados a ella, es algo que hay que tomarse muy literalmente. Ante la creciente composición orgánica de los seres humanos - ante el hecho de que en ellos incluso la porción del aparato frente a lo espontáneo se extiende de manera análoga a como ocurre en la producción material, no se encuentran seguros tampoco los que producen la cultura. Quien posee un olfato sensible para tales tendencias, puede toparse con categorías administrativas disfrazadas hasta en los productos artísticos de vanguardia, hasta en las emociones más matizadas de la persona, hasta en el acento y los gestos. No han de pasarse por alto las tendencias estéticas constatables por doquier, la construcción integral. Éstas apuntan a una especie de planificación desde arriba, cuya analogía con la administración se impone. Semejantes configuraciones estarían totalmente predeterminadas (ADORNO, 2004, p.128).

Para Marcuse (1999, p.80), “o comércio, a técnica, as necessidades humanas e a natureza se unem em um mecanismo racional e conveniente. Aquele que seguir as instruções será mais bem-sucedido, subordinando sua espontaneidade à sabedoria anônima que ordenou tudo para ele". E esse mecanismo avança para além das malhas do mercado, de acordo com este mesmo autor:

A "mecânica da submissão" se propaga da ordem tecnológica para a ordem social; ela governa o desempenho não apenas nas fábricas e lojas, mas também nos escritórios, escolas, juntas legislativas e, finalmente, na esfera do descanso e lazer (MARCUSE, 1999, p.82).

A razão dominante se instalou para além da ordem sociológica mas que também resultou em uma organização psicológica de massa, de um Eu enfraquecido coletivizado, incapaz de individuar-se, pois, pela coerção, pela ameaça de ser aniquilado, pelo medo, pelo sentimento de culpa, bem como pelos mecanismos do mundo administrado, quase nada lhe resta de condições objetivas e sociais para que haja indivíduos autônomos, aptos à experiência e ao pensamento como exercício permanente de ser alguém além de um Eu genérico por meio da relação na qual o singular se oponha ao todo social (ADORNO, 2004; 2006). O que evidencia a crise da educação enquanto formação de uma consciência esclarecida reflexiva e crítica que, segundo Adorno (2006), vem a se tratar da expressão máxima da crise social como projeto âncora da dominação, uma vez que "[...] a liberdade na sociedade é inseparável do pensamento esclarecedor" 
(ADORNO; HORKHEIMER, 2006, p.13), sem os quais e diante do estado reificado da consciência é impossível superá-lo.

Na sociedade do capital, que carece de experiências formativas intelectuais, a repressão e a hostilização são compensadas pela própria sagacidade do mercado: ele produz a fome e vende o pão. O empobrecimento das experiências é compensado virtualmente pelo entretenimento, pelo fetiche e pelo falso gozo do consumo; o Eu enfraquecido se conforma no sentimento de pertença grupal e no reconhecimento identitário de uma coletivização cega, basta-se em sentir-se representado pela noção de um Eu genérico (ADORNO; HORKHEIMER, 2006); a individuação se limita a uma falsa individuação e a uma autoconfirmação compulsória narcísica e autoritária; a repressão pulsional decorrente da não-liberdade estabelecida pela condição do mal-estar social não é sublimada, mas desloca-se a uma condição anímica mais primitiva e desequilibrada: a agressividade e a compulsão à violência - compensando, deste modo, sua repressão libidinal pelo desvio pulsional e sua pseudo satisfatoriedade pela perversão da própria reprodutibilidade psicológica da dominação (ADORNO; HORKHEIMER, 2006). Pela condição exacerbada imposta pelo todo, o Eu abdica de si próprio para poder sobreviver coletivamente. Entretanto, isso se dá de modo a lhe suprir as condições imanentes à sua felicidade, e, no doloroso processo de reconhecer sua condição, nega-a (ADORNO, 2006), tornando-se muitas vezes indiferente a essa ou, então, pelo estado de coisificação ao qual possa ter chegado, conforma-se com a dominação social e com a sua racionalidade irracional, a do horror que justifica-se, como também passa a se identificar com essa, pois sequer chegou a ter a experiência de emancipação. Para Adorno:

A necessidade de uma tal adaptação, da identificação com o existente, com o dado, com o poder enquanto tal, gera o potencial totalitário. Este é reforçado pela insatisfação e pelo ódio, produzidos e reproduzidos pela própria imposição à adaptação. Justamente porque a realidade não cumpre a promessa de autonomia, enfim, a promessa de felicidade que o conceito de democracia afinal assegurara, as pessoas tornam-se indiferentes frente à democracia, quando não passam até a odiá-la. A forma de organização política é experimentada como sendo inadequada à realidade social e econômica; assim como existe a obrigação individual à adaptação, pretende-se que haja também, obrigatoriamente, uma adaptação das formas de vida coletiva, tanto mais quando se aguarda de uma tal adaptação um balizamento do Estado como megaempresa na aguerrida competição com todos. Os que permanecem impotentes não conseguem suportar uma situação melhor sequer como mera ilusão; preferem livrar-se do 
compromisso com uma autonomia em cujos termos suspeitam não poder viver, atirando-se no cadinho do eu coletivo (ADORNO, 2006, p.43, 44).

A estrutura social, correspondendo aos interesses do capitalismo tardio, configura-se historicamente pela razão dominante que, tal como expõem as caras reflexões de Adorno e Horkheimer (2006) no conjunto de teses intitulado Elementos do antissemitismo, expressa a destruição do esclarecimento enquanto princípio do pensamento autônomo e que, para justificar o injustificável, vem a se tratar do retorno da civilização esclarecida à barbárie. O que na contemporaneidade, em sua expressão máxima, evidencia-se nas guerras, na fome, na pobreza, nas chacinas etno raciais, na violência policial, nas injustiças sociais, na realidade de desigualdades sociais, no desmatamento ambiental, problemáticas tais que poderiam há muito ter sido superadas pelo progresso técnico e pelas riquezas materiais já alcançadas pela pequena parcela mais rica da população mundial. Que, em contrapartida, volta-se para a produção do lucro, às custas da própria humanidade, da sua liberdade e de suas potencialidades criativas; a indústria cultural é o grande exemplo dessa suntuosa maquinaria da lógica do capital. Para esses autores:

[...] mesmo pelo critério da ordem existente essa aparelhagem inflada do prazer não torna a vida mais humana para os homens. A ideia de "esgotar" as possibilidades técnicas dadas, a ideia da plena utilização das capacidades em vista do consumo estético massificado, é própria do sistema econômico que recusa a utilização de capacidades quando se trata da eliminação da fome (ADORNO; HORKHEIMER, 2006, p.115).

A racionalidade da sobrevivência sob a condição do mal-estar social se desvela como mentira manifesta da irracionalidade do produtivismo lucrativo às custas da própria desfiguração humana (ADORNO; HORKHEIMER, 1973; CROCHIK, 2001). Segundo Adorno e Horkheimer:

Quando o pensamento sobre o caráter e a natureza da sociedade perde de vista a tensão entre instituições e vida, e procura resolver o social no natural, não orienta o impulso de libertação no que diz respeito à pressão das instituições mas, pelo contrário, corrobora uma segunda mitologia, a ilusão idealizada de qualidades primitivas que se referiria, na verdade, ao que surge através das instituições sociais (ADORNO; HORKHEIMER, 1973, p.32). 
A promessa do progresso, pois, consiste na regressão da própria humanidade em sua miséria a ponto de que a própria diferenciação passa a ser intolerável ao espírito coisificado (ADORNO; HORKHEIMER, 2006). De acordo com esses mesmos autores:

[...] o aumento da riqueza seja, entre outras coisas, uma das causas primordiais da autonomia que as instituições e formas de socialização adotam para os homens e, pelo contrário, passou a se afirmar e consolidar independentemente deles (ADORNO; HORKHEIMER, 1973, p.33).

A ascensão da burguesia, das máquinas, da indústria e, com elas, o princípio da eficiência competitiva marcam o movimento histórico do avanço e do predomínio do poder econômico sobre os demais e, em contiguidade, do poder tecnológico como um dos meios operantes para a formação da racionalidade técnica e para a manutenção da ordem vigente, a do capital. Nessa realidade, segundo Adorno (2006, p.43):

A ordem econômica e, seguindo seu modelo, em grande parte também a organização econômica continuam obrigando a maioria das pessoas a depender de situações dadas em relação às quais são impotentes, bem como a se manter numa situação de não-emancipação. Se as pessoas querem viver, nada lhes resta senão se adaptar à situação existente, se conformar; precisam abrir mão daquela subjetividade autônoma a que remete a idéia de democracia; conseguem sobreviver apenas na medida em que abdicam seu próprio eu (ADORNO, 2006, p.43).

Marcuse (1999) denuncia a derrocada da liberdade do sujeito econômico da sociedade liberal em decorrência do processo de produção de mercadorias fomentada pelo poder tecnológico a benefício do poderio econômico. Pela rota ameaça iminente à sobrevivência, leva a formação de indivíduos autônomos a se reduzir na produção de papéis sociais determinados. Enquanto o primeiro, resultado do processo de diferenciação do todo social, "[...] extrai das suas ações os seus próprios valores; e as palavras transmitidas pela tradição só lhe são dadas através da interpretação individual" (ADORNO; HORKHEIMER, 1973, p.50); as pessoas expressam a dinâmica da psicologia de massas, sem condição para a individuação, permanecem totalmente adaptadas e ajustadas ao princípio da eficiência em detrimento do princípio do pensamento criador (ADORNO; HORKHEIMER, 1973). Isso a ponto de o incorporar e o reproduzir em suas relações (domésticas e profissionais) e até, infelizmente, alienar-se quanto a esse processo de heteronomia e coisificação. De acordo com Adorno e Horkheimer: 
A definição do homem como pessoa implica que, no âmbito das condições sociais e que vive e antes de ser consciência de si, o homem deve sempre representar determinados papéis como semelhante de outros. Em consequência desses papéis e em relação com seus semelhantes, ele é o que é: filho de uma mãe, aluno de um professor, membro de uma tribo, praticante de uma profissão. Assim, essas relações não são, para ele, algo extrínseco mas relações em que se determina a seu próprio respeito, como filho, aluno ou o que for. [...] a pessoa é, como entidade biográfica, uma categoria social. Ela só se define em sua correlação vital com outras pessoas, o que constitui, precisamente, o seu caráter social. A sua vida só adquire sentido nessa correlação, em condições sociais específicas; e só em relação ao contexto é que a máscara social do personagem também é um indivíduo (ADORNO; HORKHEIMER, 1973, p.48).

A indústria cultural, caro conceito elaborado por Adorno e Horkheimer (2006) em A dialética do esclarecimento, constitui um mecanismo perspicaz de manipulação das massas com fins de manter coesos a ordem e o progresso do programa econômico do capitalismo por meio de uma irracionalidade racionalizada, a da dominação e do principado da racionalidade técnica, expressão da regressão do esclarecimento à ideologia e da barbárie. De acordo com esses autores, “a racionalidade técnica hoje é a racionalidade da própria dominação. Ela é o caráter compulsivo da sociedade alienada de si mesma" (ADORNO; HORKHEIMER, 2006, p.100) e, por assim ser, consiste no mecanismo mantenedor das condições para a barbárie.

A sagacidade da indústria cultural é tamanha e seu alcance inimaginável, pois oblitera e ludibria as possibilidades sociais para a resistência: o esclarecimento deixa de tomar consciência de si mesmo e pouco há condições para a auto reflexão crítica. Sendo que sua extensão ideológica alcança até mesmo a educação, a arte e a cultura, as quais são convertidas em forças produtivas. A razão transforma-se historicamente, e no contexto da racionalidade tecnológica, esta se torna prática, a relação com o conhecimento passa a ser caracterizada pela sua instrumentalização: a práxis é distanciada aversivamente da reflexão teórica, o que coincide com a perda de experiência (ADORNO, 1995).

O domínio da indústria cultural atinge a formação psicológica, em suas dinâmicas mais profundas, de modo que até aqueles que se negam e buscam enfrentar o conformismo e a submissão domesticada diante da dominação social, quando não conduzidos pela conscientização e pela racionalidade objetiva quanto a tais mecanismos sociológicos e psicológicos operantes, os reproduzem em sua práxis e em suas relações mais íntimas. O pensamento reifica-se e transforma-se em outra coisa que não ele mesmo, é reduzido ao uso instrumental técnico, à 
fórmula fixada, ao mutismo do conhecimento positivista e à regência publicitária: expressões de uma falsa consciência e, por assim ser, ideológica.

A disposição sociológica da dominação social e do autoritarismo imanente expressa sua irracionalidade bárbara de forma manifesta nas realidades de violência, de desigualdades sociais, do preconceito e do estigma, da hostilização e da exclusão social. Realidades que vêm a ser esferas do próprio processo econômico, indiferente ao próprio indivíduo em sua humanidade, uma vez que esta, também pela sua potencialidade para a autonomia, “[...] torna-se um obstáculo à produção" (ADORNO; HORKHEIMER, 2006, p.167), sujeitando-os ao anonimato massificado e reduzindo-os ao interesse quanto à sua força de trabalho. Somado a isso, a constituição psicológica correspondente à dominação é o fascismo: a ânsia pela “[...] posse exclusiva, a apropriação, o poder sem limites, a qualquer preço" (ADORNO; HORKHEIMER, 2006, p.140). Sua essência é a violência que se transveste nas relações psíquicas sadomasoquistas, no fetichismo e na perversão, cuja irracionalidade racionaliza como ameaça à ordem estabelecida tudo aquilo que se diferencia dela, da sua normativização genérica e administrativa. O autoritarismo é a condição desesperada e severa para a preservação do seu Eu enfraquecido que não tolera ser descoberto, a consciência reificada é a sua moeda de troca: “[...] a impotência daquilo que poderia refreá-los, a impotência da reflexão, da significação e, por fim, da verdade. O passatempo pueril do homicídio é uma confirmação da vida estúpida a que as pessoas se conformam" (ADORNO; HORKHEIMER, 2006, p.142). O antissemitismo passado sobrevive no presente, pois não foi superado.

A formação e a reprodução deliberada de concepções estereotipadas e a ausência do reconhecimento social igualitário é decorrente do antissemitismo burguês e racista (ADORNO; HORKHEIMER, 2006), e que pode expressar a sua impessoalidade violenta nas mais diferentes formas nas relações sociais, políticas e institucionais do passado e na contemporaneidade. Na leitura de Honneth (2003, p.122), isso “[...] se dá a saber aos sujeitos pela experiência de um desrespeito, de sorte, que eles se veem levados a uma luta por reconhecimento". Isso implica na possibilidade de uma luta política pela transformação social em detrimento da própria identificação racionalizada com a dominação social e com a sua idiossincrasia violenta, uma tentativa de resistência à consciência reificada como forma de tornar consciente conteúdos da idiossincrasia e de seu absurdo (ADORNO; HORKHEIMER, 2006), por meio da qual a pessoa desrespeitada violentamente em seus direitos espera um dia "[...] estar seguro do valor social de 
sua identidade" (HONNETH, 2003, p.137), o que, diante disso, revela a expressão de elementos de uma força contrária à serventia voluntária e ao conformismo diante da opressão social, bem como revela restos de uma possível autonomia sobrevivente, mesmo que sob a condição de oprimidos (ADORNO; HORKHEIMER, 2006). Envolve, neste caso, segundo Honneth (2003), a luta pelo reconhecimento nas instâncias jurídicas, sociais e interpessoais, para que, por meio delas, também haja garantia objetiva para o reconhecimento de especificidades antes socialmente excluídas, de modo a se fazer efetiva a relação entre o universal e o individual, a universalidade coletiva pelo reconhecimento dos sujeitos de direito e a expressão positiva das "[...] diferenças individuais entre os cidadãos de uma coletividade" (HONNETH, 2003, p.139).

A luta por reconhecimento é identificada nos intentos propositivos da práxis das organizações sociais e do ativismo, muitos dos quais desenvolvem seus trabalhos dentro de campos de saberes e de produção de saberes que consideram forças políticas contrárias aos mecanismos da dominação social e da sua condição de esclarecimento alienado devido à sua potencialidade política para a formação do pensamento esclarecido: a arte, a cultura e a educação, uma vez que estas remetem ao protesto permanente do particular contra o universal (ADORNO, 2004) pela capacidade da conscientização sensível e reflexiva.

Essas organizações, apesar da sua diversidade contextual, propositiva e interventiva, apresentam uma práxis orientada pelo caráter de função social: seja a de se fazerem ouvidas as pessoas socialmente invisibilizadas e desfavorecidas; de suas vidas humanas serem respeitadas e reconhecidas pelas esferas públicas e sociais por meio da arte, da educação estética e da cultura popular, fazendo da cultura uma “arte de lutar" (MOVIMENTO CULTURAL DAS PERIFERIAS, 2018); seja por meio da formação cultural, da cidadania e da emancipação social a partir do desenvolvimento humano e do senso crítico.

No que se refere aos movimentos e coletivos culturais, esses cantam, rimam, declamam, grafitam ou mesmo gritam suas vozes negras, pardas, nordestinas e indígenas para que elas ecoem e atravessem a sua invisibilidade social e historicamente determinada desde os porões dos navios negreiros, os muros das estereotipias e dos estigmas sociais e dos discursos hegemônicos correspondentes para que, de algum modo, haja a desconstrução gradativa da hierarquia de valores sociais, para que suas próprias narrativas, estéticas e repertórios culturais sejam compreendidos, respeitados e incorporados nas normas reconhecidas socialmente enquanto 
sujeitos de iguais direitos e valor. E, no campo dos projetos socioculturais educativos, mais especificamente, a educação é compreendida como, segundo Gohn:

[...] um conjunto de práticas socioculturais de aprendizagem e produção de saberes, que envolve organizações/instituições, atividades, meios e formas variadas, assim como uma multiplicidade de programas e projetos sociais. [...] engloba saberes e aprendizados gerados ao longo da vida, de forma individual ou coletiva - a exemplo de experiências via a participação social, cultural ou política em determinados processos de aprendizagem, tais como em projetos sociais, movimentos sociais, programas de formação sobre direitos humanos, cidadania, práticas identitárias, lutas contra desigualdades e exclusões sociais etc. Elas estão no centro das atividades das ONGs nos programas de inclusão social, especialmente no campo das artes, educação e cultura. A música tem sido, por ter características de uma linguagem universal e por atrair a atenção de todas as faixas etárias, o grande espaço de desenvolvimento de programas e projetos da educação [...] (GOHN, 2015, p.16,17).

Para a superação da barbárie é preciso se lançar ao grande desafio de uma evolução psicológica e sociológica da sociedade que se contraponha à ideologia dominante que os escraviza. Segundo Honneth (2003), um dos passos fundamentais para isso consistiria em "[...] um processo de ampliação gradual dos conteúdos do reconhecimento jurídico" (p.144). Para Adorno (2005, 2006), porém, trata-se, anteriormente às competências jurídicas ou civis, da formação dos próprios sujeitos, indivíduos aptos à experiência intelectual e à auto reflexão crítica, ou seja, de sujeitos capazes de pensar a realidade à sua volta. Para a concretude da democracia, a normatização jurídica que a representa no contexto institucional formal da política não dá conta da superação da racionalidade dominante, nesta circunstância, ela é ideológica: apesar de caminhar para o seu alicerçamento, a democracia será apenas aparente enquanto não forem superados os mecanismos sociais e a psicologia profunda do fascismo, a começar pela própria conscientização de tal psicodinâmica (ADORNO, 2006). Para uma democracia verdadeira, segundo Adorno (2006), é necessária a formação de sujeitos preparados psicologicamente para tal, o que implica uma formação conscientemente planejada para a autodeterminação, por meio da qual haveria condições reais para a consistência de tais competências humanas mediante a ética do pensamento (o exercício da crítica e autocrítica permanente) em confronto com o estado deliberado da consciência alienada, da semicultura e do predomínio da adaptabilidade social coercitiva, cuja transformação somente é possível pelas vias da educação, ou melhor, de uma educação planejada para a democracia. Para Adorno: 
[...] a produção de uma consciência verdadeira. Isto seria inclusive da maior importância política; sua idéia, se é permitido dizer assim, é uma exigência política. Isto é: uma democracia com o dever de não apenas funcionar, mas operar conforme seu conceito, demanda pessoas emancipadas (ADORNO, 2006, p.141).

Ao encontrarem-se articulados com os esforços comunitários para evidenciar o genocídio da juventude pobre e preta, para debater a carência de investimentos e de políticas públicas na região, para reclamarem justiça social, bem como para a descentralização de investimentos públicos para as margens da cidade, os movimentos e coletivos culturais das periferias da zona sul de São Paulo, contexto territorial comunitário referente ao campo empírico da presente pesquisa, assim como das demais periferias da cidade, contestam e reivindicam os diferentes conteúdos correspondentes aos direitos subjetivos classificados por Honneth (2003): os direitos liberais de liberdade, os direitos políticos de participação e os direitos sociais de bem-estar, que, conforme é apresentado por Honneth:

[...] a primeira categoria refere-se aos direitos negativos que protegem a pessoa de intervenções desautorizadas do Estado, com vista à sua liberdade, sua vida e sua propriedade; a segunda categoria, aos direitos positivos que lhe cabem com vista à participação em processos de formação pública da vontade; e a terceira categoria, finalmente, àqueles direitos igualmente positivos que a fazem ter parte, de modo eqüitativo, na distribuição de bens básicos (HONNETH, 2003, p.189).

Em contiguidade a isso, e em concordância com algumas das reflexões benjaminianas em Crítica da violência --- Crítica do poder, pode-se pensar que as organizações sociais se organizam também com uma intenção para uma crítica da violência, bem como para a sua superação, tendo em vista que, segundo Walter Benjamin:

A tarefa de uma crítica da violência pode ser definida como a apresentação de suas relações com o direito e a justiça. Pois, qualquer que seja o efeito de uma determinada causa, ela só se transforma em violência, no sentido forte da palavra, quando interfere em relações éticas (BENJAMIN, 1986, p.160).

Essas diferentes organizações socioculturais e educativas, em sua potencialidade à crítica estética e a uma "arte da inclusão" (COOPERIFA, 2012), estão a todo momento enfrentando o 
desrespeito e a exclusão das periferias do tecido social da grande metrópole, das esferas públicas e privadas, políticas, sociais, econômicas e culturais, e não somente no que diz respeito à sua geografia. Identificamos, aqui, a interferência nas relações éticas de socialização e, consequentemente, na formação de indivíduos. Ao mobilizarem sua própria arte, cultura e estéticas para o alinhamento a discursos, à criação de ações e à realização de intervenções políticas de resistência e de existência - envolvendo, por exemplo, o resgate de memória de bairro, o mapeamento de seus territórios, denúncia e exigência dos direitos humanos, promoção de acesso cultural (teatro, cinema, literatura, etc.) - por meio de "[...] um espaço concreto de formação com a aprendizagem de saberes para a vida em coletivos” (GOHN, 2009, p.32), estão assim produzindo um trabalho educativo para a democratização, constatando-se, pois, um caráter de política cultural.

Todavia, cabe pensar se tais expressões artísticas e culturais, bem como as propostas educativas estéticas dessas organizações sociais, conseguem, em suas estéticas e planejamentos pedagógicos, sedimentar seus conteúdos de verdade e suas críticas sociais sem que isso seja imposto ou arquitetado de antemão à própria criação ou produção estética, sem que coincida “com a perda de experiência causada pela racionalidade do sempre-igual” (ADORNO, 1995, p.203), ou seja, sem que recaiam à ordem da cultura administrada. Para a objetividade da crítica à violência e para a construção e efetivação de projetos e práticas educativas formativas, é necessário, anteriormente a isso, a capacidade para a própria autocrítica individual, grupal e institucional quanto à objetividade de sua própria práxis política cultural, visto que "[ [...] a barbárie continuará existindo enquanto persistirem no que têm de fundamental as condições que geram esta regressão" (ADORNO, 2006, p.119).

De acordo com o trabalho conceitual benjaminiano de práxis no âmbito da arte, ao artista cabe a conquista e a transformação do imagético (BENJAMIN, 1986), o que, por sua vez, requer a experiência estética e a capacidade para a elaboração de um julgamento fundamentado: expressões de uma consciência sensível tanto do criador quanto de seu espectador. A luta por reconhecimento por meio dos movimentos e projetos socioeducativos e culturais assemelha-se a isso no sentido de intentar uma ressignificação do imaginário social quanto às estéticas estereotipadas acerca das periferias, quando a invisibilidade social de um grupo é rompida por um processo de ampliação gradual dos conteúdos do reconhecimento (HONNETH, 2003), no 
entanto, isso não é o mesmo que dizer que para a concretude desse reconhecimento social tenha ocorrido de fato a desbarbarização da consciência reificada.

A configuração que caracteriza, de modo geral, as organizações sociais, cujos conteúdos éticos, solidários, políticos e humanos se encontram estruturados em seus objetivos, valores, missões e princípios (GOHN, 2009, 2015) assemelham-se expressivamente com os sentidos e finalidades que compõem a ideia de educação política proposta por Adorno (2006), a qual, entretanto, só é possível mediante a experiência formativa e a elaboração do passado que, segundo esse mesmo autor (ADORNO, 2006), significa o reavivamento valorativo da memória, da lembrança e do tempo histórico como pressupostos insubstituíveis para a aprendizagem, para a educação emancipatória e para a formação cultural e não, como se faz crer, a proposta de uma promessa falsa da prosperidade material e de consumo de massas (ADORNO; HORKHEIMER, 1973).

Logo, significa ser uma desafiadora ruptura com o condicionamento da racionalidade vigente, a teoria de mônades, regida pela lei do valor de troca, atemporal e rítmica da produção e consumo de bens. Ou seja, trata-se de uma resistência contra a lei objetiva do desenvolvimento burguês e “[...] pelas sólidas barreiras impostas pelas condições vigentes” (ADORNO, 2006, p.35) por meio de uma educação capaz de resgatar e prover as condições para a autonomia, eliminadas pela própria sociedade burguesa.

A transformação imagética quanto à percepção social sobre as comunidades periféricas pela arte exige, anterior e simultânea a esta, um projeto de educação política no sentido de uma educação para a experiência intelectual, para a formação de uma consciência sensível e, por seu turno, para a concretização da formação cultural enquanto capacidade da apropriação subjetiva reflexiva da cultura (ADORNO, 2005). Para isso, cabe problematizar os sentidos e os tipos de relações estabelecidas com a arte nesse contexto grupal e institucional de modo a não tomá-la pelo fetichismo burguês encoberto e pela relação de uso, de forma a garantir condições consistentes e conscientes para a expressão estética de conteúdos de verdades objetivas referentes ao repertório cultural dessas comunidades (ADORNO, 1993), em detrimento do retorno à reprodutibilidade alienada de mecanismos da indústria cultural: a promessa do novo com a estrutura do sempre-igual (a estandardização musical, a função determinada, a diversão, etc.).

Por mais que haja um trabalho para a desconstrução do autoritarismo difundido na formação subjetiva das pessoas, por mais que esse seja confrontado e enfrentado pelas mais 
diversas organizações sociais político-culturais e educacionais, não podemos nos abster do fato de que todos nasceram e foram (pseudo)formados a partir do mesmo princípio de realidade, pela condição do mal-estar social e por uma educação que domestica os seres humanos e os seus sentidos para o admirável mundo novo administrado, despidos das condições para a experiência de sua liberdade, autonomia e individualidade. Se ausentes dessa conscientização, a práxis social perde sua objetividade, respondendo ilusoriamente aos anseios subjetivos pela transformação social quando, na verdade, reproduzem os mesmos mecanismos sociológicos e ideológicos da dominação social, da cultura administrada e da pseudoformação (ADORNO, 1995; 2004, 2005). Ou seja, se ausente da disposição para a auto reflexão crítica da própria práxis, esta se torna uma falsa práxis, recaindo a uma racionalidade utilitária e que mais responde às demandas anímicas e pulsionais do que às condições objetivas e sociais necessárias para uma transformação social no sentido de haver possibilidade para a autodeterminação emancipada e para a democracia operante (ADORNO, 1995, 2004, 2006). Discussão que converge com a ideia de trabalho social útil imanente à racionalidade dominante, racionalidade oculta da cultura administrada, que, conforme Adorno, "El concepto de trabajo socialmente útil no se puede separar de la socialización integral; este concepto se le presentaría necesariamente también a ese cuya utilidad se documenta exclusivamente en su negación, y la salvación bendeciría difícilmente al salvado" (ADORNO, 2004, p.126).

Corre-se o risco, pois, de se contentar com um estado psicológico identitário, a uma estética coletiva que supere imageticamente a sua invisibilidade, a sua exclusão, e a opressão sofrida, distanciados inconsciente e contraditoriamente da formação cultural e do pensamento. Desta forma, conforme Adorno:

[...] o mais importante para enfrentar o perigo de que tudo se repita é contraporse ao poder cego de todos os coletivos, fortalecendo a resistência frente aos mesmos por meio do esclarecimento do problema da coletivização. Isto não é tão abstrato quanto possa parecer ao entusiasmo participativo, especialmente, das pessoas jovens, de consciência progressista (ADORNO, 2006, p.127).

À luz da compreensão conceitual proposta por Adorno (1993, 2005, 2006), pôde-se compreender as noções de formação e cultura como campos de forças e, por assim dizer, de coexistência e tensionamentos entre os caracteres inerentes a elas: emancipação e adaptação; autonomia e dominação, pensamento e alienação. Seu “desejado equilíbrio é momentâneo" 
(ADORNO, 2005, p.4), só seria estático em seu retrato utópico ou numa esperança ingênua demais, pois a arte, a educação, a formação e a cultura transformam-se nas relações do tempo histórico, bem como sua necessidade. Essas são regidas pelas mesmas forças que regem as relações sociais e, ao mesmo tempo, são estranguladas e reificadas quando num desequilíbrio pujante da dominação, recaindo, assim, à ideologia dominante, no sentido de esta última inviabilizar e substituir o pensamento.

A era prolongada do capital desfaz-se da cultura enquanto trabalho humano criativo e assola todos os planos dinâmicos da "sociologia e psicologia da educação", enfraquecendo as possibilidades reais para a apropriação subjetiva autônoma daquela, ou seja, para a formação cultural. Consequentemente, de acordo com Adorno:

A formação cultural agora se converte em uma semiformação socializada, na onipresença do espírito alienado, que, segundo sua gênese e seu sentido, não antecede à formação cultural, mas a sucede. Deste modo, tudo fica aprisionado nas malhas da socialização. Nada fica intocada na natureza, mas, sua rusticidade - a velha ficção - preserva a vida e se reproduz de maneira ampliada. Símbolo de uma consciência que renunciou à autodeterminação, prende-se, de maneira obstinada, a elementos culturais aprovados. Sob seu malefício gravitam como algo decomposto que se orienta à barbárie (ADORNO, 2005, p.2).

Há aqui, portanto, uma dolorosa contradição imanente ao ser humano da sociedade regida pela dominação e pelo controle do capital: o enfrentamento vívido e lúdico pela arte e pela cultura contra os processos de desigualdades sociais, preconceito e opressão não necessariamente consiste em uma práxis que faça resistência contra a dominação social, o que se refere à própria subjetivação de seus mecanismos operantes pelos membros desses grupos e organizações (ativistas, educadores, lideranças políticas, artistas socialmente engajados, etc.). Para isso, o caminho árduo da autoconscientização é emergente, tendo-se que "as reflexões precisam portanto ser transparentes em sua finalidade humana" (ADORNO, 2006, p.161) para evitar, assim, o domínio oculto de mecanismos da cultura administrada, do narcisismo coletivo, da personalidade autoritária e da consciência reificada em si mesmos e nas relações grupais inerentes, não podendo subestimar a perspicácia da indústria cultural e o domínio da semicultura. É necessária a experiência de emancipação dos próprios responsáveis e organizadores desses projetos interventivos e educativos-formativos. 
Para a formação cultural, é preciso o indivíduo, a relação entre sujeito e objeto, a experiência intelectual, a qual não se dá, antes, sem a relação entre teoria e práxis, que, segundo Adorno (1995):

A razão pura prática, com todo realismo zeloso, é tão desprovida de objeto quanto o mundo é desqualificado para a manufatura e a indústria que o reduzem a material de elaboração e que, por sua vez, não pode legitimar-se senão no mercado. Enquanto a práxis promete guiar os homens para fora fora do fechamento de si, ela mesma tem sigo, agora e sempre, fechada; é por isso que os práticos são inabordáveis, e a referência objetiva da práxis, a prior minada. Até se poderia perguntar se, até hoje, toda práxis, enquanto domínio da natureza, não tem sido, em sua indiferença frente ao objeto, práxis ilusória. Seu caráter ilusório transmite-se também a todas as ações que, sem solução de continuidade, tomam da práxis o velho e violento gesto (ADORNO, 1995, p.202).

Por mais que esse protagonismo político cultural pela arte e pelo ensino das mais diversas linguagens artísticas esteja de fato contribuindo seja para a desconstrução inicial dos estigmas sociais, para a valorização, respeito e maior visibilidade dos repertórios culturais das comunidades periféricas, seja para o enfrentamento das desigualdades sociais e realidades de opressão, deve-se tomar conta e juízo de que, ao mesmo tempo que isso se trata de uma força solidária que se volta contra os processos repressivos da cultura e da desumanização, isso, contudo, não é tudo e nem é o suficiente. Cabe também a importante consciência, apesar de dura, quanto à profundidade enraizada das problemáticas sociais e interpessoais a serem enfrentadas advindas da "[...] própria organização do mundo em que vivemos e a ideologia dominante" (ADORNO, 2006, p.143) na nossa subjetividade e em nossa práxis, seja ela política, social, educacional e/ou cultural.

Para este estudo, a escolha da investigação empírica sobre a dinâmica de um projeto social que desenvolve trabalhos assistenciais e de educação musical para o público infantojuvenil da periferia da extrema zona sul da cidade de São Paulo se deu em concordância com as análises críticas de Adorno (2005) - contíguas à área do estudo da psicologia social, da educação e do desenvolvimento humano -, sobre as possibilidades reais do confronto pedagógico contra a semicultura, que, segundo ele, “[...] somente uma atuação de psicologia profunda poderia contestá-la, uma vez que, em fases precoces de desenvolvimento, se afrouxam seus bloqueios e se pode fortalecer a reflexão crítica" (ADORNO, 2005, p.17). Isso não significa, todavia, que este trabalho por si só daria conta de subvertê-la no contexto dos projetos socioculturais educativos, 
mais especificamente, mas sim de tensionar as suas relações vigentes e, por fim, problematizá-las criticamente à luz do conhecimento teórico conceitual da Teoria Crítica, em especial, das contribuições teóricas de Theodor Adorno. O que permitiu, por sua vez, a conscientização quanto à complexidade do objeto de estudo investigado no tocante às suas potencialidades e contradições de uma práxis cultural.

Seria ingenuidade científica debruçar tão somente sobre dimensões particularizadas da educação estética proposta pela escola de música participante e colaboradora desta pesquisa, sem considerar a sua relação com o todo, a práxis engajada das organizações sociais. Dentro do escopo dessa investigação, o tratamento dos dados empíricos se deu de modo a se pensar e a se problematizar questões psicossociais inerentes à educação para a emancipação e à formação cultural a partir do cenário institucional das organizações sociais, de modo que esse estudo teve como espinha dorsal a relação entre o particular e o universal (ADORNO, 1995). À vista disso, buscou-se pensar sobre o tipo de relação estabelecida com a arte e a educação nesses contextos institucionais a partir da análise de sua práxis (ADORNO, 1995, 2006) à luz da realidade da cultura administrada, da razão dominante e da condição do mal-estar social.

Mais do que o desenvolvimento de uma avaliação sobre o método pedagógico adotado, o objetivo desta pesquisa foi o de refletir sobre os seus conteúdos formativos e discutir criticamente sobre a fundamental necessidade de se "pensar no sentido e na finalidade da formação cultural" (ADORNO, 2005, p.5) na educação dos mais diversos cenários institucionais e, mais especificamente, dentro do contexto de coletivos e movimentos culturais comunitários e de projetos sociais do Terceiro Setor.

A educação estética não necessariamente viabiliza condições para a experiência estética, mas uma possibilidade objetiva para esta, a depender da qualidade de seu planejamento (ADORNO, 2006). O que envolve, por sua vez, conhecimento teórico formal para a verificação e análise estrutural do material estético de uma obra de arte, de sua consistência e harmonia entre parte e todo; como também, recursos objetivos que não se limitem ao ensino instrumental da técnica, mas que possam contribuir "[...] para o comportamento interior, para a consciência da realidade" (BECKER apud ADORNO, 2006, p.145) pelo desenvolvimento inicial da aptidão à experiência estética já na tenra infância, como, por exemplo, o tempo desmedido para a relação e contemplação desinteressada, e, a liberdade e respeito singular para a expressão segura da espontaneidade de seus alunos. Que, de acordo com Adorno (2011), diz respeito à formação 
pensante dos sentidos, para a qual, a relação direta e o envolvimento com o objeto são fundamentais (ADORNO, 1993). Significa, por sua vez, um tensionamento frente à usual práxis com sentido de utilidade social.

Talvez possa-se aqui pontuar que a educação estética seria uma condição para a possibilidade de crítica social ao longo do desenvolvimento humano e da formação cultural, conforme o tipo de socialização promovida pela instituição escolar e a possível individuação em que se encontra cada pessoa (ADORNO, 2005; ADORNO; HORKHEIMER, 1973). A pesquisa se ateve, portanto, a esse passo anterior, convocando, assim, a uma investigação sobre essa práxis formativa, cuja função social é deliberadamente determinada de antemão, convergente ao sentido do termo de engagement (ADORNO, 1993): a que fins se destina e ao que com ela, quer-se, de fato, promover. O que leva, dessarte, a caminhar conjuntamente com as reflexões críticas de Adorno (2006) em seu livro Educação e Emancipação, e que envolveu, para o avanço desse estudo, considerações acerca de alguns dos elementos componentes e fomentadores da lógica dominante, também presentes direta ou indiretamente no planejamento da educação contemporânea, destacando-se, em especial, a influência da indústria cultural sobre o processo formativo, ou melhor dizendo, da pseudoformação (ADORNO, 2004, 2005, 2006). Ao mesmo tempo, também, que a concepção de arte de Adorno (1993) orientou o desenvolvimento das compreensões acerca da relação estabelecida com a estética dentro do contexto específico de organizações socioculturais dos e nas periferias, uma vez que também as reflexões sociológicas elaboradas por Adorno sobre arte, estética e cultura, suscitaram algumas reflexões críticas sobre a realidade social vigente, levando, por sua vez, a verificar nas diferentes dimensões componentes desses grupos artísticos, culturais e educativos uma relação convergente com o termo de engagement (ADORNO, 1993) e com a conversão da estética reflexiva crítica em força estética produtiva com caráter de função social.

E a partir da compreensão dos "'[...] momentos parciais, imanentes ao sistema, que atuam em cada caso no interior da totalidade social” (ADORNO, 2005, p.2), foi possível melhor compreender reflexivamente a relação entre o particular institucional e o todo social, entre os mais diferentes tipos de organizações sociais atuantes nos territórios periféricos e as dinâmicas convergentes com o projeto socioeducativo participante da pesquisa empírica, de forma a identificar uma complexa malha de formas de enfrentamento da dominação social, da intenção 
para a superação da barbárie e, contraditoriamente, a reprodução de mecanismos da dominação, da pseudoformação e da semicultura.

Nesta pesquisa, buscou-se em sua própria práxis elaborar um trabalho escrito a partir da compreensão da perspectiva dialética, e, nesse sentido, foram desenvolvidas uma investigação e uma problematização acerca das contradições ideológicas presentes na democratização da formação cultural por meio da educação estética musical. Não para mantê-la reservada ao privilégio burguês e ao domínio da racionalidade administrada que a esvazia, mas para despir suas vestimentas íntimas e sagazes da dominação e, assim, ceifar os auto enganos ingênuos das vontades e da cegueira de determinadas práxis (ADORNO, 1995). E, por fim, buscou-se averiguar as reais possibilidades de transformação social e para a emancipação dos sujeitos ou, ao menos, problematizá-las, visto que se pode tomar por formação cultural um vislumbre desta, ou mesmo, reproduzir a dinâmica da cultura administrada. Para Adorno:

Cuantas más cosas ocurren en pos de la cultura, tanto peor para ella, sentenció Eduard Seuermann. Esta paradoja habría que desarrollarla: que es nociva cuando se planifica y administra; que, sin embargo, cuando-se la deja a su libre arbitrio, todo lo cultural amenaza perder no sólo la posibilidad de influencia, sino la existencia. Ni hay que tomar acríticamente el concepto ingenuo de cultura que se impuso hace tiempo acompañado de representaciones sectoriales, ni mantenerse en la conservadora sacudida de cabeza respecto de lo que le ocurre a la cultura en los tiempos de la organización (ADORNO, 2004, p.115).

E para a efetivação concreta da democracia, conforme opera seu conceito, faz emergente o comprometimento com a sua objetividade e não com as intenções subjetivas imanentes, por mais que essas compartilhem deveras a vontade legítima pela transformação social para a democracia. Conforme Adorno:

Isso não significa, porém, que se deva ficar cego, por medo do inevitável, diante de suas implicações, nem, sobretudo, diante do fato de que entra em contradição com as pretensões imanentes de democratizar a formação cultural. Somente uma concepção linear e inquebrantável do progresso espiritual planeja com negligência sobre o conteúdo qualitativo da formação que se socializa como semiformação. Frente a ela, a concepção dialética não se engana sobre a ambiguidade do progresso em plena totalidade repressiva. $O$ que os antagonismos enraízam é que todos os progressos em relação à consciência da liberdade cooperaram para que persista a falta de liberdade. Esta falta de liberdade é esfera global sobre a qual brilha a frase comovedoramente ilusória, extraída do antigo repertório de idéias social-democráticas e lema analisado por 
Benjamin em uma de suas teses histórico-filosóficas: "Nossa causa está ficando cada vez mais clara e o povo cada dia mais esclarecido"... Assim como na arte não existem valores aproximados e que uma execução medianamente boa de uma obra musical não expressa em termos médios seu conteúdo - pois toda execução fica sem sentido quando não inteiramente adequada -, assim também ocorre com a experiência espiritual como um todo. $\mathrm{O}$ entendido experimentado medianamente - semi-entendido e semi-experimentado - não constitui o grau elementar da formação., e sim seu inimigo mortal. Elementos que penetram na consciência sem fundir-se em uma continuidade, se transformam em substâncias tóxicas e, tendencialmente, em superstições, até mesmo quando as criticam, da mesma maneira como aquele mestre toneleiro que, em seu desejo por algo mais elevado, se dedicou à crítica da razão pura e acabou na astrologia, evidentemente porque apenas nela seria possível unificar a lei moral que existe em nós com o céu estrelado que está sobre nós. Elementos formativos inassimilados fortalecem a reificação da consciência que deveria justamente ser extirpada da formação (ADORNO, 2005, p.12,13).

Deste modo, contíguo à função da Teoria Crítica, a de analisar criticamente os princípios da formação social e da formação cultural para que deste modo seja possível de se pensar em seu devir, este estudo é o resultado de uma investigação dos bastidores, de algumas das dimensões desconsideradas enquanto conteúdos inerentes ao planejamento da educação musical. Permite reconhecer a complexidade da extensa trama social que envolve todo e qualquer fenômeno social, a produção correspondente da subjetividade, as suas sonoridades e os seus murmúrios. E que, por fim, essa dissertação de mestrado consistiu em um exercício desafiador e em uma pequena tentativa para se contribuir com a possibilidade da auto-reflexão sobre a pseudoformação, que, para Adorno (2005, p.18), vem a ser "a única possibilidade de sobrevivência que resta à cultura" e, por meio dessa, resgatar a liberdade e a humanidade, a energia que "[...] desapareceu das idéias que a formação compreendia e que lhe insuflavam vida" (ADORNO, 2005, p.11). 


\section{OBJETIVOS E HIPÓTESES}

Este trabalho teve como objetivo desenvolver uma investigação analítica reflexiva sobre a práxis formativa de um projeto sociocultural educativo localizado em uma área de periferia da extrema zona sul de São Paulo (SP), o qual apresentou como finalidade colaborar com a formação

psicossocial e cultural de crianças e adolescentes por meio da educação musical. Pretendeu-se também identificar e pensar sobre as possíveis contradições presentes em sua ambientação, organização, planejamento político-pedagógico e as práticas realizadas nesses espaços artísticos culturais, bem como investigar a real potencialidade da arte e da educação estética nos dias atuais no contexto das organizações sociais de modo geral.

Para isso, em um primeiro momento desta pesquisa, por meio da pesquisa bibliográfica e do mapeamento territorial realizados, buscou-se desenvolver uma análise panorâmica acerca das organizações sociais (movimentos e coletivos culturais comunitários e projetos sociais de modo geral) atuantes em comunidades das periferias, mais especificamente, sobre os sentidos e finalidades atribuídos à arte, cultura e educação e sobre o tipo correspondente de práticas socioeducativas e culturais desenvolvidas. Em seguida, pretendeu-se desenvolver uma investigação empírica, por meio da qual foram analisados elementos estruturantes e ideológicos inerentes à organização do projeto participantes e ao seu planejamento político-pedagógico: objetivos, princípios e valores; perspectivas discursivas; abordagens metodológicas; fundamentação dos sistemas de ensino-aprendizagem; formação dos educadores e dos demais envolvidos com a formulação desses projetos; tipo de práticas de ensino musical envolvidas e seus possíveis desafios; etc. Por fim, por meio deste trabalho, visou-se à elaboração de uma análise reflexiva fundamentada na leitura de autores da Teoria Crítica da Sociedade de modo a se orientar pela guisa da relação entre o universal e o particular, que permitisse uma compreensão dinâmica de aspectos gerais do dinamismo social e dos modos de atuação das organizações sociais nas periferias, e de aspectos mais específicos do projeto social participante, como também, a sua relação com a organização social e psicológica do capitalismo tardio.

E, tendo-se como contexto determinante a atual sociedade, mais propriamente a realidade da Grande São Paulo, objetivou-se verificar se essas práticas promovem, de fato, condições para a experiência formativa por meio de práticas interventivas e educativas estéticas e culturais, mais especificamente, por meio da educação musical, para as quais é imprescindível o envolvimento de 
seus alunos e alunas, e, portanto, a consideração e o conhecimento embasado sobre as diferentes realidades infantis e juvenis das periferias urbanas - "de sua realidade, de sua vida, de sua voz" (PIRANDELLO, 1927 apud BENJAMIN, 1975, p.22). Ou seja, é possível identificar se há potencialidade política e social nesse tipo de práxis em uma realidade social condicionada a uma cultura administrada?

Em decorrência do problema de pesquisa, algumas hipóteses foram levantadas quanto aos possíveis resultados a serem obtidos. As hipóteses em questão consistem em conjecturas referentes, sobretudo, à relação entre o princípio de realidade social dominante, a concepção de educação emancipatória de Theodor W. Adorno (2006), o planejamento pedagógico e as práticas culturais propostas por projetos e organizações sociais voltadas à estética e à educação musical infantojuvenil.

Foram formuladas, deste modo, três hipóteses:

1. No que se refere à relação da arte com a sociedade, tal como verificado pelos autores frankfurtianos, a arte deixou de ser valorizada pela sociedade burguesa em ascensão já nos séculos XVIII e XIX, em seu sentido enquanto autonomia, experiência estética e capacidades reflexivas e críticas - assim como também o foi qualquer âmbito de saber que propiciasse a formação de pensamento que ameaçasse a ordem da dominação social instaurada (ADORNO, 1993; ADORNO; HORKHEIMER, 2006). O rebaixamento da consciência sensível e intelectual à sua coisificação e a decadência da arte séria são retratos atuais da sociedade organizada pelos interesses econômicos do capitalismo tardio e pela dominação social correspondente e, possivelmente, são até mais críticos quanto ao seu consequente processo deformativo humano, tendo-se em vista a ascensão desenfreada da racionalidade tecnológica e administrativa (ADORNO, 2004) e, ao mesmo tempo, a continuidade da crise da educação, da miséria humana e a falência das experiências (BENJAMIN, 1996). Processo no qual, segundo esses autores, a arte foi reduzida ao caráter de bens culturais de diversão, de entretenimento, foi convertida em mercadoria pelo valor de troca (ADORNO, 1993; ADORNO; HORKHEIMER, 2006). Esse processo de desvalorização da arte - enquanto âmbito possível do saber e da formação cultural encontra-se, hoje, naturalizado na realidade social brasileira pela cultura administrada, pela consciência musical de massas e pelo fetichismo cultural. Encontramos expressões disso, por exemplo, nos baixos incentivos, investimentos e implementações da arte na base 
do planejamento e da fundamentação da educação e da formação cultural - seja no que se refere aos projetos e programas educacionais e pedagógicos; seja nas respectivas práticas institucionais; nas medidas e leis correlacionadas; e, até na própria produção científica.

2. Há contradições presentes nas práticas educacionais, propositivas e interventivas das organizações sociais no contexto de uma realidade marcada pela dominação social e pela supremacia da racionalidade administrativa. Pode-se supor a identificação de paradoxos quanto àquilo a que se propõem e afirmam promover e aquilo que é de fato produzido como, por exemplo, questões referentes à: arte versus entretenimento; experiência estética versus vivência aparente; formação versus pseudoformação.

3. Por fim, levando-se em conta a conceituação de arte e de música proposta por Adorno (1986; 1993; 2011), supõe-se ser ainda possível uma educação planejada para a formação cultural e, mais especificamente, o desenvolvimento humano inicial para a diferenciação e para o pensamento criativo por meio da educação estético musical, caso haja fundamentação teórica conceitual reflexiva de sua práxis e disposição para a autocrítica permanente da mesma (ADORNO, 1995; 2006). Apesar das condições operantes na realidade atual, estas não são, possivelmente, sinônimo de um processo totalizado de aniquilamento da expressão das potencialidades da arte autônoma e da educação emancipatória. Ainda subsistem condições para a formulação consistente e consciente de uma educação estética musical em seu sentido de desenvolvimento humano para individuação (ADORNO, 2006). Os elementos proponentes e constitutivos de uma educação consciente e consistente para a experiência devem estar dispostos nas mais diferentes dimensões psicossociais que a envolvem, tais como o tipo de ambientação e socialização grupal e institucional, os conceitos utilizados e o repertório técnico musical adotado.

Isto posto, nesta dissertação, buscou-se responder à seguinte pergunta de pesquisa: Projetos sociais que desenvolvem trabalhos de educação musical infantojuvenil nas periferias da cidade de São Paulo oferecem condições para a concretude de uma educação emancipatória e, assim sendo, para a formação cultural? 


\section{MÉTODO}

\subsection{Pesquisa bibliográfica}

Para a realização deste estudo, foi realizado um levantamento bibliográfico por meio da consulta dos portais eletrônicos da SciElo (Scientific Electronic Library Online), da PePSIC e da base de dados Sociological Abstracts, de modo a se ter conhecimento sobre a literatura científica produzida atualmente sobre a práxis cultural e formativa de projetos sociais. E, visando a uma síntese mais organizada e consistente dessa literatura, como também, à elaboração de uma análise sobre os resultados encontrados e sobre o panorama da produção científica - em especial, da área da psicologia no contexto brasileiro -, buscou-se estabelecer algumas estratégias dinâmicas de busca, para as quais, teve-se como referência publicações científicas sobre a qualidade metodológica desta modalidade de pesquisa (ALVES, 1992; ZOLTOWSKI et al., 2014). As bases de dados anteriormente citadas foram, por sua vez, escolhidas por apresentarem, em especial, quase a totalidade da produção psicológica indexada do país. Sendo selecionados como material de leitura artigos científicos, sem restrição de data. Além disso, como estratégia complementar de busca, foi realizada a consulta de referências bibliográficas indicadas no material lido na íntegra.

Primeiramente, foram consultados os portais eletrônicos SciELO e PePSIC, utilizando-se algumas opções de conjuntos de palavras-chaves: 1."educação estética, música, formação cultural, teoria crítica"; 2. "educação musical AND estética AND formação cultural”; 3. "educação AND música AND periferia”; 4. "educação AND música AND projeto social”; 5. "música AND projeto social AND periferia”. Essas diferentes combinações de descritores se deram em decorrência do pequeno número de resultados obtidos, a fim de também se verificar e confirmar essa pequena incidência de publicações científicas sobre a temática proposta. Contando-se, assim, com um resultado inicial de 5 artigos, havendo duplicação de alguns dos conjuntos desses descritores; tendo-se, então, 4 artigos distintos ao todo, os quais foram devidamente organizados em uma planilha de acordo com a base de dados utilizada, com o conjunto de palavras-chaves, título, ano de publicação, periódico, estrato e área de conhecimento (ANEXO A).

A partir do material encontrado, foi dada sequência à pesquisa bibliográfica por meio da base de dados Sociological abstracts, a qual configura um acervo eletrônico de diferentes tipos de 
materiais (títulos de periódicos, livros, capítulos de livros, dissertações e trabalhos apresentados em congressos, por exemplo), onde é indexada a literatura internacional concernente especialmente à área de conhecimento da sociologia, na qual, estão vinculadas algumas produções científicas da psicologia. A escolha dessa base de dados se deu, principalmente, pelo fato de termos adotado a Teoria Crítica da Sociedade, que consiste em uma linha de análise social e psicológica (ADORNO, 2004). Além disso, essa base de dados tem como principais temáticas, dentre outros assuntos, a educação, a cultura e o desenvolvimento social, âmbitos elementares para o desenvolvimento deste trabalho. Perante os diferentes conjuntos de descritores utilizados anteriormente, optou-se pelas palavras-chaves "Educação AND Música AND Projeto social AND Periferia", já que foi através da combinação, em separado, desses dois últimos conectores com os demais que obtivemos, anteriormente, resultados pertinentes à nossa temática. Como resultado inicial, foram encontrados 58 trabalhos ao todo, sem duplicação. Sendo descartados, já pelo título, aqueles que indicaram pouca ou nenhuma correspondência com o objeto de estudo da nossa pesquisa, restando apenas três artigos para a análise dos seus resumos. Estes também foram devidamente organizados em uma planilha (ANEXO B).

Os resumos dos artigos selecionados foram analisados em seus conteúdos e, em seguida, foram utilizados critérios de inclusão e exclusão, sendo eles uma adaptação realizada a partir de um estudo referencial sobre qualidade metodológica de revisões sistemáticas (ZOLTOWSKI et al., 2014), tendo sido, aqui, adotados com o intuito de melhor circunscrever o recorte e os limites do alcance investigativo da presente pesquisa. Pela análise dos conteúdos, foram eleitos materiais que dialogassem com a temática de educação estética e, ao mesmo tempo, com o seu cenário contextual e institucional (periferias e organizações sociais, respectivamente). Quanto aos critérios de inclusão, foram utilizados os seguintes:

a) ser um artigo completo;

b) estar publicado em um periódico indexado nas áreas da psicologia, da sociologia, da educação e da música.

Depois de analisados pelos critérios de inclusão, os materiais que responderam positivamente a todos eles foram, em seguida, analisados pelos critérios de exclusão, sendo eles:

a) periódicos que não abarcam estudos realizados no Brasil e/ou na América Latina; 
b) periódicos que não apresentaram foco nas áreas da psicologia, da sociologia, da educação e da música;

c) periódicos com estrato inferior a B1.

Cada periódico foi consultado em sua fonte online para que se conferisse o seu foco de publicação; como também, o estrato de cada um foi verificado por meio da avaliação da Qualis periódicos da CAPES (PLATAFORMA SUCUPIRA, 2016).

O material encontrado no PePSIC foi selecionado, uma vez que esta é uma base específica da área de psicologia; enquanto que dentre o encontrado no portal de periódicos da SciELO, por se tratar de uma base multidisciplinar, foram incluídas apenas as publicações da área das ciências humanas, tendo-se que os periódicos da psicologia, da educação e da sociologia se encontram agrupados nesta grande área de conhecimento. Foram selecionados três dos quatro artigos encontrados, os quais foram analisados em seguida pelos critérios de exclusão, tendo sido, à luz dos critérios aqui estabelecidos, avaliados como relevantes para o avanço do nosso estudo. Quanto às produções científicas encontradas na base de dados Sociological Abstracts, os três artigos selecionados responderam satisfatoriamente aos critérios do nosso procedimento, sendo eles considerados de significativa pertinência para o desenvolvimento da nossa pesquisa e, assim sendo, foram lidos na íntegra.

Cabe ressaltar, novamente, que a seleção deste material se deu, sobretudo, tendo-se em vista que o método, de acordo com a perspectiva da Teoria Crítica, é definido pelo próprio objeto e, deste modo, o principal fator orientador utilizado para o desenvolvimento desta busca bibliográfica foi a análise prévia dos próprios conteúdos apresentados nos resumos dos artigos pré-selecionados. Os critérios de inclusão e exclusão, por sua vez, foram adotados com a finalidade de serem referenciais de busca, a fim de se evitar uma amostra muito heterogênea. Isso favoreceu uma melhor delimitação do escopo investigativo dentro dessa modalidade de pesquisa.

\subsection{Mapeamento territorial}

A contextualização do território, onde a instituição participante está inserida, se fez necessária para melhor referenciá-la e, assim, para dar maior consistência para o desenvolvimento da análise dos dados coletados, especialmente, dos dados empíricos. Para isso, foram consultadas fontes de órgãos públicos como os sites da Prefeitura de São Paulo, das 
subprefeituras regionais relacionadas ao território em questão, documentos legislativos, sites de organizações civis como o da Rede Nossa São Paulo, de coletivos e movimentos culturais locais, como também, algumas reportagens jornalísticas. Foram examinados dados provenientes do Índice Paulista de Vulnerabilidade Social (IPVS), também conhecido como o mapa de vulnerabilidade do município de São Paulo. Criado pelo SEADE, esse indicador nos permitiu conhecer algumas das condições de vida nas diferentes localidades espaciais da cidade de São Paulo e de seus respectivos segmentos populacionais e compará-las às da região do extremo sul da cidade. E devido à extensão das áreas assistidas por esse projeto social (referente aos bairros onde reside a população atendida), optou-se por pesquisar os dados oficiais da subprefeitura da Cidade Ademar e de Pedreira por serem essas regiões formalmente referenciadas pelos documentos institucionais consultados, como também, pelo fato de que a administração dos bairros atendidos está sob a responsabilidade daquelas e, deste modo, trata-se de uma amostra representativa de toda a área abarcada. Além disso, por meio deste mapeamento territorial, também foi possível identificar algumas das organizações sociais existentes nas regiões de periferias da zona sul de São Paulo.

\subsection{Pesquisa empírica}

\section{a) Contexto institucional}

A coleta de informações sobre o trabalho desenvolvido pela escola de música, assim como a caracterização descritiva da ambientação dos espaços da instituição, foram realizadas para dar maior consistência à análise dos dados. Para isso, foram consultados materiais legislativos e institucionais do projeto social em questão, além dos conteúdos contidos em seu website; a descrição do cenário foi possível por meio das observações de campo realizadas durante as visitas ao projeto participante.

\section{b) Observações de campo}

Ao longo da pesquisa de campo, conjuntamente com as entrevistas, foram realizadas observações passivas, as quais foram devidamente registradas em um diário de campo depois de algumas das visitas realizadas na escola de música. Por meio delas, buscou-se descrever a ambientação do projeto: a estrutura dos espaços físicos, a dinâmica das aulas e a relação entre a equipe e os alunos. Para isso, foram realizadas uma visita guiada pela coordenadora pedagógica 
do projeto, que apresentou todos os espaços da escola de música, e observações passivas desses mesmos locais durante os intervalos das atividades; além disso, foram acompanhadas algumas das atividades propostas, dentre elas, um ensaio do coral infantil, uma atividade de prática de grupo e uma aula de teoria musical.

\section{c) Entrevistas}

Essa atividade foi organizada a partir de um modelo de entrevistas semidirigidas, tendo-se como apoio a utilização de um roteiro (ANEXO C), criado pela autora desta pesquisa, cujas perguntas foram organizadas por blocos temáticos, os quais, por sua vez, foram elencados com base no repertório conceitual de estética, música, educação e formação cultural de Adorno (1993, 2005, 2006, 2011).

Para a realização das entrevistas, inicialmente, o projeto de pesquisa foi submetido ao Comitê de Ética em Pesquisa com Seres Humanos (CEPH) do Instituto de Psicologia da Universidade de São Paulo via Plataforma Brasil, atendendo a todas as exigências deste órgão. Para isso, foram elaborados os documentos: 1. carta de autorização da instituição participante; 2. demonstrativo de existência de infraestrutura institucional; e, 3. Termo de Consentimento Livre e Esclarecido (TCLE), todos devidamente anexados juntamente com o projeto de pesquisa na Plataforma Brasil. As entrevistas foram realizadas somente após a autorização do CEPH.

Para a realização das entrevistas, foram adotadas considerações teóricas de Pierre Bourdieu (1997), as quais contribuíram para se pensar o método enquanto uma "reflexividade reflexa", buscando-se, assim, respeitar a primazia do objeto e a relação social estabelecida com os participantes deste tipo de dispositivo de pesquisa.

As entrevistas foram realizadas em salas reservadas na própria localidade da escola de música durante o ano de 2018; foram gravadas, com autorização dos participantes, transcritas e tabuladas, e os dados foram organizados a partir de uma análise horizontal entre elas. 


\section{RESULTADOS}

\subsection{Pesquisa bibliográfica}

Neste trabalho bibliográfico, como resultado inicial, foi obtido um pequeno número de publicações científicas nos portais eletrônicos SciELO e PePSIC, sendo quatro artigos científicos ao todo. Dentre os resultados obtidos, dois deles são oriundos da área da Educação, um da Psicologia e um da Música, tendo sido este último eliminado depois da análise do seu resumo, pois sua proposta temática apresentou pouca interlocução com a da presente pesquisa. Os trabalhos em questão foram publicados entre os anos de 2002 e 2018. Já na busca realizada na base de dados Sociological Abstracts foram obtidas inicialmente 58 produções científicas, das quais foram selecionadas três para a leitura na íntegra, sendo um das Ciências Sociais e dois da Sociologia especificamente, cujas publicações se deram nos anos de 2016, 2010 e 2013, respectivamente.

Quanto aos conteúdos contemplados, identificamos que apenas um dos trabalhos encontrados abordou como temática central a educação musical e a formação cultural infantojuvenil nas especificidades do contexto institucional de projetos sociais e do contexto territorial de periferias. Em um segundo trabalho, houve a discussão sobre a relação entre a educação musical, a formação de sujeitos criativos e o papel dos educadores; no entanto, tratavase de um estudo voltado para o cenário institucional de escolas regulares. Em outro, foram elaboradas críticas pertinentes sobre as manifestações culturais que ocorrem nas periferias, sendo eleitas para o enfoque da análise questões como seus sentidos políticos, o papel de projetos sociais, a arte produzida nesses espaços, como também suas ambivalências, especialmente em relação aos interesses de mercado. Nas demais publicações, os autores apresentaram discussões sobre questões convergentes às do nosso estudo, mas a partir de enfoques que o tangenciam, destacando-se, como exemplo, a discussão sobre o rap e o funk e a sua relação com a juventude das periferias, com o seu processo de socialização; como também, sobre as relações sociais estabelecidas com esses estilos musicais e, por conseguinte, com seus ouvintes. Discussões que tocaram, de maneira articulada, em temas como o preconceito, o estigma e a segregação social, tendo em vista que essas produções musicais estão historicamente atreladas e associadas ao contexto social das periferias. Os resultados obtidos nos permitiram concluir que o nosso recorte 
temático foi, até então, pouco investigado pela academia científica brasileira na produção de artigos científicos, em especial pela área da Psicologia, indicando-nos a relevância deste estudo.

Em um dos artigos consultados, a educação musical em projetos sociais foi compreendida a partir da sua possibilidade para a resiliência, sendo que o desenvolvimento e transformação social do público atendido consiste, geralmente, em um dos principais objetivos das instituições filantrópicas. De acordo com o contexto das periferias, segundo a autora deste artigo, "especificamente nos projetos sociais que se direcionam aos jovens, comumente se observa a incorporação de atividades projetadas [...] para que os mesmos vivam melhor no meio social em que habitam e que operem sobre ele de um modo efetivo e transformador" (PERES et al., 2018, p.62). Para isso, as principais frentes de atuação e intervenções dos projetos sociais são a promoção da inclusão social, a oferta de cursos técnicos, o acolhimento de jovens em situação de risco e oferecimento de bolsas como fonte de renda aos jovens desempregados (BEZERRA, 2009 apud PERES et al., 2018). A educação musical, dentro deste contexto, é vislumbrada como campo possível de "vivências de enfrentamento", buscando-se, por meio dela, transformar as adversidades vividas por esses jovens em "potencialidades de crescimento" (PERES et al., 2018, p.62). Entretanto, observou-se que, no conjunto de práticas envolvidas, o sistema de ensinoaprendizagem musical usualmente restringiu-se, estabelecendo pouco diálogo com a comunidade à sua volta durante as atividades observadas.

Dentre os conteúdos elencados na discussão do material consultado, destacaram-se as problematizações acerca das culturas periféricas e do sentido político das atividades artísticas e culturais que acontecem nesses territórios: os conflitos e as denúncias estéticas, a afirmação política de pertencimento territorial e suas ambivalências, em especial, a capitalização da cultura. No contexto das periferias, a relação mercadológica com a cultura aparece inerente à necessidade expressa de subsistência individual e familiar, visto que as populações referentes compreendem "grupos sociais subalternos que geralmente têm acesso a postos de trabalho caracterizados pela baixa qualificação, remuneração e gratificação pessoal” (TOMMASI, 2013, p.17). Em decorrência disso, foi observada uma justaposição das razões sociais e políticas da cultura com as de valor de troca, posto que, segundo Tommasi (2013, p.16), o “[...] corpo que cria, que produz arte, é também um corpo que precisa se vestir, habitar, comer" (TOMMASI, 2013, p.16).

Outro aspecto relevante foi o de constatar que a efervescência cultural das áreas marginalizadas das grandes capitais está provocando um sentimento de pertencimento 
comunitário, a formação de grupos identitários, a elevação da autoestima individual e coletiva (de ser periférico) e uma "sensação de cidadania", para além da valorização e da motivação da criatividade e expressão estética dos moradores. Por outro lado, a gestão de diversos grupos, movimentos e projetos socioculturais vem se assemelhando à da gestão empresarial, à de um empreendedorismo econômico de cunho social: seja pela disputa de editais de financiamento fator dificultador para a articulação de rede entre esses trabalhos -; seja pela proliferação de cursos e oficinas - que fazem uso das diferentes modalidades artísticas com propostas que prometem 'promover o chamado 'protagonismo' juvenil, a 'elevação da autoestima' e a "conquista da cidadania" como formas de enfrentamento ao tráfico de drogas e à violência (TOMMASI, 2013, p.20) -; seja, enfim, pela transformação da identidade estética das periferias em produto de mercado, cuja identidade de "ser periférico" também se tornou um importante valor agregado.

Em três dos artigos selecionados, foi retratada uma discussão pertinente sobre estilos musicais tidos como repertórios característicos das periferias, destacando-se, entre eles, o funk e o rap. Esses estilos musicais foram caracterizados como uma expressão cultural identitária de jovens das periferias, propiciando condições para "a vivência da própria condição juvenil" (DAYRELL, 2002, p.121), tornando-se um espaço para o protagonismo juvenil em algumas circunstâncias (eventos culturais, formação de grupos musicais, shows e bailes), assim como, estéticas possíveis para o engajamento político dos jovens periféricos por meio de intervenções artísticas (TAKEUTI, 2010), o que parece colaborar para produção de um olhar sobre si mesmo e sobre a realidade à sua volta "[...] com intenção de inventividades na busca de 'vias de saída' para a sua limitada condição de vida de jovens de "periferia"” (TAKEUTI, 2010, p.14): a pequena oferta de espaços, programas e políticas públicas culturais nas áreas marginalizadas dos grandes centros urbanos. Busca-se, pois, de algum modo, desafiar o elitismo cultural e a cultura dominante; ao mesmo tempo que aderem e fomentam a estrutura de consumo de meios de comunicação de massa (DAYRELL, 2002; TAKEUTI, 2010; TOMMASI, 2013). A possibilidade para a ressignificação da trajetória de muitos jovens das periferias por meio do rap e do funk se deu a partir do próprio consumo de bens culturais como, por exemplo, CDs e shows; e que suscitaram naqueles, como alternativa, o interesse de se tornarem produtores musicais, de formar grupos musicais e de se tornarem MCs famosos como busca por reconhecimento social e legitimação identitária (DAYRELL, 2002). Além disso, possibilitam a ampliação da sua própria 
rede de relações, em que "reconhecem-se no funk, compartilham situações lúdicas, encontram-se nos bailes, sentindo-se parte de uma rede simbólica (ARCE, 1999 apud DAYRELL, 2002, p.132)", provocando a necessidade de reflexão sobre si mesmos e sobre a realidade social, em especial, da juventude pobre e negra, o que é estimulado intencionalmente principalmente pelo rap (DAYRELL, 2002; TAKEUTI, 2010). Outro aspecto social abordado dentro deste escopo temático foi a expressão do preconceito, das desigualdades e do estigma social presentes nas diferentes formas de relações com as pessoas residentes nas periferias que se desdobram na concepção social geral a respeito desses estilos musicais, sobretudo, o funk. Sobre eles recai uma conotação pejorativa, marcada pelo discurso das grandes mídias, em que foram identificadas diversas alusões associativas entre esses estilos musicais, seus ouvintes e a violência nos morros e favelas, o tráfico, a "bandidagem" e a figura do "pivete" (TROTTA, 2016). A repercussão midiática dos "rolezinhos", ocorridos no ano de 2016, foi um exemplo disso.

\subsection{Mapeamento territorial}

O projeto social referência da nossa pesquisa empírica está inserido e é atuante no distrito de Pedreira, vinculado à subprefeitura da Cidade Ademar, região periférica do extremo sul da cidade de São Paulo, localizado às margens da represa Billings. Conforme se pode localizar no mapa abaixo:

Figura 1. Identificação da localização e área de atuação da ONG na cidade de São Paulo

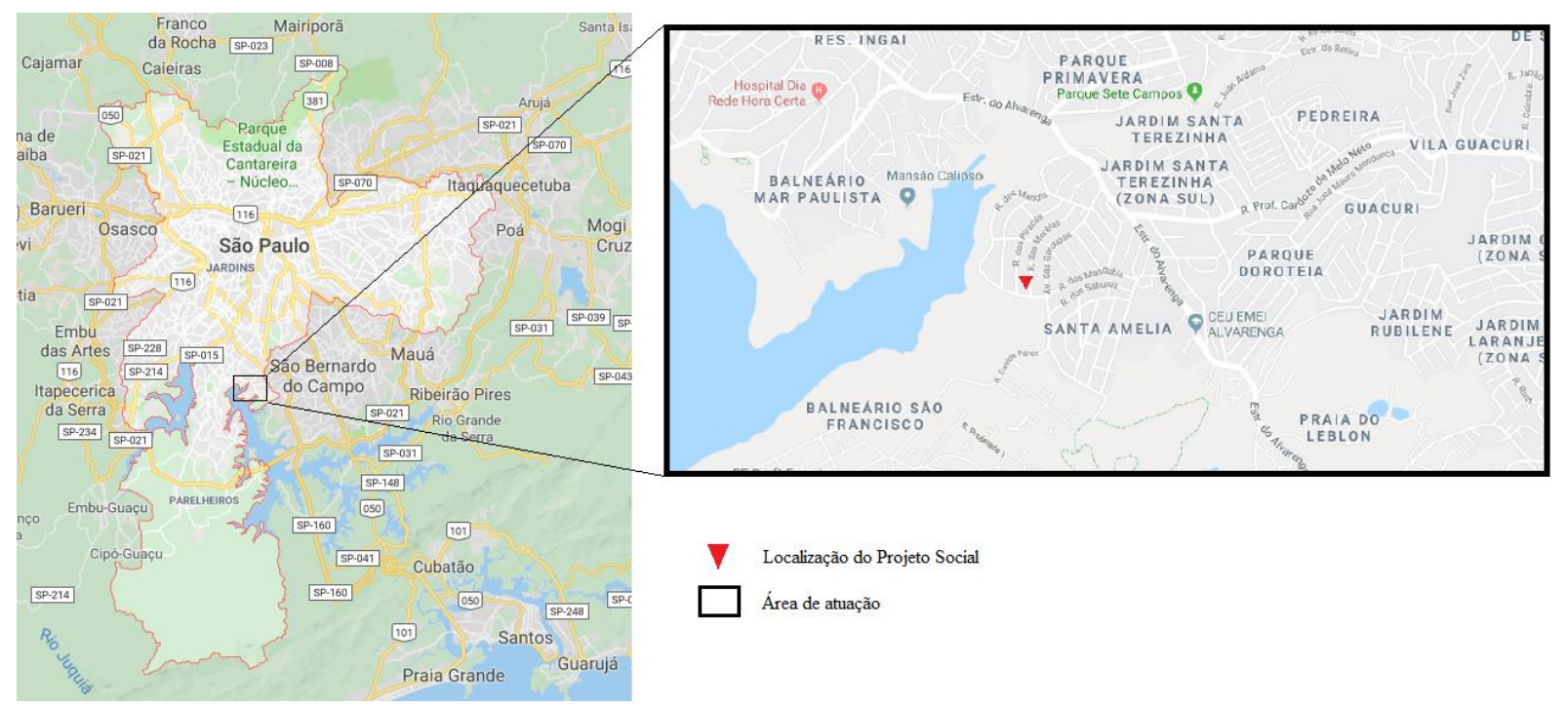

Fonte: Google Maps (2019) - (editado) 
De acordo com os dados levantados sobre essa região, o Distrito de Pedreira, juntamente com a Cidade Ademar, possuem uma população total com cerca de 410.998 habitantes (PREFEITURA DE SÃO PAULO, 2017). Até 2016, mais de 50\% da população residente era composta por pessoas autodeclaradas pretas e pardas, concentração e distribuição populacional semelhante às das demais margens da cidade de São Paulo (CEERT, 2015; REDE NOSSA SÃO PAULO, 2016). O Distrito de Pedreira apresentou IDH de 0,777 (SÃO PAULO, 2007), sendo classificado como uma área de alta vulnerabilidade social, segundo análise da Fundação Sistema Estadual de Análise de Dados (SEADE). E, de acordo com o levantamento de dados organizados pelo IPVS de 2018, identificamos, de modo geral, um quadro de vulnerabilidades sociais nessa região, referente, principalmente, à pobreza e à deficiente rede de equipamentos e de serviços públicos.

Foram verificados índices médio alto e alto de famílias, idosos, pessoas com deficiência, crianças e jovens cadastrados pelo Cadastro Único do Governo (CadÚnico) e que são assistidos pela transferência de renda de diversos programas socioassistenciais (PREFEITURA DE SÃO PAULO, 2010, 2016, 2017). A elevada concentração de pessoas e famílias que não possuem meios suficientes para o seu próprio sustento e são assistidas por meio desses programas é um indicativo de pobreza na região em questão. Além disso, foi observado um padrão quanto à distribuição dessas populações de acordo com a sua localização territorial: as maiores concentrações de pessoas atendidas por esses programas residem nas extremidades periféricas; seguidas pelo Centro e por algumas áreas da Zona Sudeste, Nordeste e Zona Leste 1; tendo as Zonas Oeste e Centro Sul os menores índices (PREFEITURA DE SÃO PAULO, 2010).

A rede de serviços e de equipamentos socioassistenciais presente no território circunscrito é contemplada por apenas sete serviços e programas dentre os cerca de 52 existentes em São Paulo (rede pública em parceria e rede pública direta) (PREFEITURA DE SÃO PAULO, 2016), sendo eles: 1. Núcleo de Convivência do Idoso (NCI); 2. Centro para crianças e adolescentes; 3. Centro para a juventude; 4. Centro de Convivência Intergeracional (CCINTER); 5. Serviço de Assistência Social à Família e Proteção Social Básica no Domicílio; 6. Serviço de Acolhimento Institucional para crianças e adolescentes e 7. Centro de Referência de Assistência Social (CRAS). 
Essa região foi também caracterizada pela questão problemática do aumento de moradias irregulares que vêm avançando e se instalando sobre mananciais e sobre outras áreas de preservação ambiental nos últimos quatro anos, em decorrência dos grandes empreendimentos imobiliários e dos exacerbados valores de mercado dos grandes residenciais - dentre essas localidades, destacam-se as áreas ambientais da Cidade Ademar, como também, a região da Capela do Socorro e Parelheiros (FOLHA DE SÃO PAULO, 2017). Pedreira e Cidade Ademar estão entre os distritos de São Paulo com as maiores porcentagens de domicílios em favelas (21,03\% e 20,73\%, respectivamente), de acordo com os dados levantados pela Rede Nossa São Paulo (2016), tendo-se como principal fonte de dados o IBGE. Além disso, no que diz respeito à questão ambiental, a Cidade Ademar apresentou o pior indicador quanto à existência de áreas verdes públicas $(0,773)$ dentre os demais distritos de São Paulo.

No campo da saúde, essa região também possui indicadores alarmantes, alguns chegando ao marco zero, como, por exemplo, o número de leitos hospitalares (públicos e privados) (REDE NOSSA SÃO PAULO, 2016).

Quanto às políticas, programas e serviços públicos de cultura, aspecto elementar para o desenvolvimento do nosso estudo, de acordo com os dados reunidos pela Rede Nossa São Paulo (2016, 2017), o Distrito de Pedreira e da Cidade Ademar apresentaram indicadores culturais zero no que se refere à disponibilidade de acervos de livros infanto-juvenis e para adultos; centros culturais, casas e espaços de cultura; cinemas (públicos ou privados); museus e salas de concertos e shows. Conta-se, apenas, com o CEU Alvarenga, o qual, com a nova gestão da prefeitura, vem sofrendo com redução de ações e projetos culturais. Conforme um estudo realizado pelo Movimento Cultural das Periferias (2017), que buscou investigar o orçamento e as políticas culturais da cidade de São Paulo, identificou-se elevada concentração de investimentos nas regiões economicamente privilegiadas e/ou visadas (Oeste, Centro e Centro Sul) em detrimento das demais, tal como se pode acompanhar no mapa a seguir: 
Figura 2 - Equipamentos públicos de cultura - SP (2018).
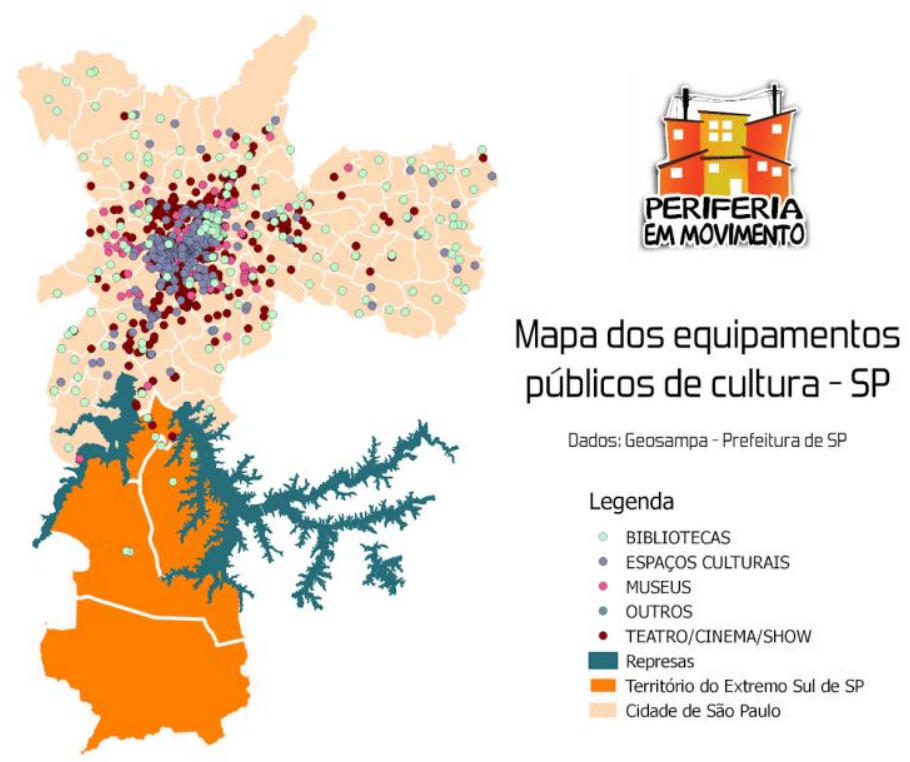

FONTE: Periferia em Movimento. Reprodução de imagem.

No que se refere à atuação dos próprios moradores das regiões mencionadas, bem como das demais comunidades periféricas da zona sul de São Paulo, foram mapeados projetos e ações coletivas e comunitárias, destacando-se aqueles voltados à arte, à cultura e à educação (em especial, aos trabalhos voltados para a estética musical, visual e literária), por meio dos quais as pessoas residentes dessas áreas apresentam seu próprio repertório cultural e estético, mediante o qual também lutam pelo cumprimento de seus direitos. Foram localizadas, ao todo, sete organizações socioculturais comunitárias, atuantes nas periferias da cidade de São Paulo, especialmente, no extremo sul da cidade (destas, quatro são oriundas da Cidade Ademar), sendo elas: Rádio Tambor; Quebrada Cultural da Cidade Ademar; Coletivo Arte Fato; CAP - Coletivos Culturais Cidade Ademar e Pedreira; Periferia em Movimento; Cooperifa e Movimento Cultural das Periferias (MCP).

De modo geral, essas organizações sociais caracterizam-se como movimentos e coletivos culturais e apresentam diferentes formatos e propostas de atuação nas comunidades periféricas. Dentre essas, destacam-se os projetos que promovem espaços de encontro e diálogos entre os jovens e músicos locais; espaços e encontros para se pensar sobre as estéticas periféricas; ações culturais educativas (cursos, oficinas, workshops sobre discotecagem e música percussiva da 
região, sobre o direito à comunicação e a representação prática nas mídias jornalísticas, por exemplo); construção de meios de comunicação midiática alternativos (rádio web e websites jornalísticos); os saraus culturais; intervenções culturais fixas e itinerantes; ocupações e exposições artísticas; fóruns populares, rodas de conversas e seminários envolvendo a articulação de diferentes coletivos e atores das periferias de São Paulo para a discussão de problemáticas sociais, políticas, culturais e sobre os direitos humanos e, consequentemente, para a promoção de um “escambo de saberes” (MPC, 2018); participação em atos, manifestações e eventos externos aos próprios movimentos; grupos de trabalhos; e participação nas audiências públicas da Câmara Municipal de São Paulo, estabelecendo diálogo entre o poder público e os movimentos culturais das periferias. Com o objetivo de fortalecer e dar maior visibilidade aos conteúdos culturais próprios da região, parte dessas organizações desenvolve um trabalho de articulação entre os coletivos artísticos culturais da região e das demais periferias da zona sul e das demais localidades marginalizadas da cidade de São Paulo, com o intuito de formar uma rede de colaboração entre os diversos grupos e as suas diferentes modalidades artísticas.

Nos anos de 2006 e 2013, foi organizado um importante evento cultural por uma rede de coletivos culturais dos distritos de Cidade Ademar e de Pedreira em parceria com a Prefeitura de São Paulo. As atividades foram realizadas, principalmente, no CEU Alvarenga, também localizado na Zona Sul. A proposta e realização dessa ação cultural evidenciaram a existência de uma rede de mais de 15 coletivos, os quais desenvolvem trabalhos com maracatu, samba de terreiro, tambor de crioula, artes visuais, cinema e música, e que têm em comum o objetivo de “ocupar o vazio cultural dos bairros" (AGÊNCIA MURAL, 2013). Outro evento que também teve destaque na Cidade Ademar foi o festival Rock na Veia, realizado pelo coletivo Arte Fato.

Comum à maioria das organizações mapeadas, o caráter político da arte e da cultura foi evidenciado e apresentado como sentido orientador de suas práticas: em vista das relações sociais marcadas pela divisão de classes, preconceitos étnico-raciais, pela heteronormatividade, e, em decorrência, pelos estereótipos, estigma social, pela hostilidade, pela opressão e pela exclusão social - fenômenos socioculturais que se estendem e também se expressam nos termos da própria cartografia urbana e que se transvestem com as especificidades das diversas problemáticas sociais - e, assim sendo, em vista, mais especificamente, do encarceramento em massa e do genocídio negro, da condição precária da mulher negra, do apagamento da memória territorial das lutas populares, do desmonte da cultura, do direito à cidade e à educação de qualidade, esses grupos e 
projetos socioculturais se relacionam com a estética, arte e cultura enquanto meios para o enfrentamento dessa realidade histórica de adversidades de modo a acreditar que por meio delas seja possível não apenas denunciar a realidade cotidiana de pobrezas, mas, sobretudo, compartilhar suas riquezas artísticas, culturais e de militância (CAP, 2014).

Esses projetos pretendem reconhecer e fazer ecoar as vozes das periferias, suas realidades, suas histórias e suas próprias narrativas a partir de "[...] uma perspectiva 'de dentro pra dentro"” (PERIFERIA EM MOVIMENTO, 2009) como forma de enfrentar o discurso das grandes mídias e a perspectiva predominante de que as periferias são áreas de pobreza, violência, tráfico de drogas e de carência, mostrando que, a contraponto das balas perdidas noticiadas nos grandes jornais, "há muita poesia solta no ar das periferias" (COOPERIFA, 2012, vídeo). Para superar a violência local, a alienação e a inércia social, buscam por fortalecer o protagonismo cultural das periferias - o qual encontra-se fortemente atrelado à história de luta dos povos pretos, caracterizando-se como uma espécie de quilombo cultural. De modo geral, pôde-se observar que o sentido político configurado à arte e à cultura nesse tipo de contexto grupal está vinculado à ideia de práticas e intervenções enquanto campo possível de luta pela visibilidade e pelo respeito social quanto aos seus repertórios culturais, a garantia de direitos, a justiça social e a descentralização de investimentos públicos para as margens da cidade (MOVIMENTO CULTURAL DAS PERIFERIAS), bem como enquanto formas educativas e formativas que possam colaborar com a formação do senso crítico. E, contíguo a isso, busca-se por resgatar a autoestima da periferia, encorajar o ser poeta de cada um e fortalecer ainda mais a cultura marginal, além de propor que sejam os moradores das periferias os próprios agentes da transformação de sua realidade social comunitária.

\subsection{Pesquisa empírica}

\section{Consulta documental e do website da escola de música}

A escola de música, projeto socioeducativo cultural participante e que contribui com o desenvolvimento dos nossos estudos, faz parte de uma Organização Não Governamental (ONG), fundada em 2005. Sua sede está localizada na zona sul da cidade de São Paulo, em uma região periférica próxima à represa Billings, no Distrito de Pedreira, que se encontra sob o domínio administrativo público da subprefeitura da Cidade Ademar (SP). Atualmente, essa instituição atende especialmente aos moradores dos bairros Balneário São Francisco, Parque Santa Amélia, 
Pedreira, Parque Dorotéia, Jardim Santa Terezinha, Santa Lúcia, Cidade Nova Pantanal e Guacurí, assistindo a cerca de 450 crianças e adolescentes. A associação atua nessa região desde Janeiro de 2006, oferecendo serviços à comunidade local, os quais foram legalmente reconhecidos pelo poder legislativo do Estado de São Paulo como de utilidade pública.

A ONG em questão atua dentro dessa região realizando atividades assistenciais, educativas, artísticas, culturais, esportivas e de educação ambiental, por meio das quais, segundo consta na sua apresentação institucional, visa colaborar com a formação psicossocial e cidadã das crianças e adolescentes em situação de vulnerabilidade social. Privilegia-se “[...] a realização de atividades lúdicas, culturais e esportivas, o desenvolvimento de competências e habilidades, o reconhecimento do microterritório, o recontar da história comunitária e individual e a construção de projetos individuais e coletivos". São realizados, por exemplo, trabalhos de reciclagem de lixo e de consumo consciente dos recursos da natureza, oficinas de artes plásticas e de musicalização infantil e aulas de capoeira e de ju-jitsu em parceria com outras associações esportivas da comunidade. Além disso, desde 2015, a ONG passou a gerir uma creche da região, destinada às crianças de quatro meses a quatro anos de idade. Esse projeto social dedica-se, principalmente, ao público infantojuvenil, mas também possui trabalhos voltados à população idosa e aos familiares das crianças e adolescentes atendidos, buscando, de maneira geral, realizar "ações socioassistenciais de forma continuada, gratuita e planejada [...]” para esses públicos. As atividades são realizadas no contraturno escolar, funcionando nos períodos da manhã e da tarde e sendo organizadas por faixas etárias (6-8 anos; 9-11 anos; 12-15 anos). Recentemente, no ano de 2016, em decorrência do envolvimento do público infantojuvenil com as atividades musicais propostas por essa ONG, devido, em especial, à formação de uma banda de alunos e alunas e às ações desenvolvidas por esse grupo (apresentações e shows), foi criada a escola de música como um novo braço da associação, tratando-se, assim, de um projeto sociocultural recente.

Atualmente, a escola de música atende mais de cem crianças e adolescentes residentes dos bairros vizinhos, de 8 a 17 anos e 11 meses de idade. Para a participação nesse projeto, é realizado antes um processo seletivo para verificar o interesse das crianças e adolescentes inscritos, que são avaliados pelos integrantes dos projetos. Geralmente, os perfis dos alunos admitidos são os de crianças e jovens da comunidade que não possuem recursos financeiros para estudarem em uma escola de música particular, muitos deles sendo considerados pelos avaliadores em situação de vulnerabilidade e exclusão social. 
Para a sua realização e manutenção, esse projeto recebe auxílio financeiro tanto público como privado, destacando-se como principais fontes de arrecadação o Fundo Municipal dos Direitos da Criança e do Adolescente (FUMCAD) da Prefeitura de São Paulo e incentivos fiscais concedidos pela Lei Rouanet (art.18), pelo Programa de Fomento Paulista de Incentivo à Cultura ProAC ICMS da Secretaria de Estado da Cultura, pelo Programa Municipal de Apoio a Projetos Culturais (ProMAC) de São Paulo e pelo Conselho Estadual dos Direitos da Criança e do Adolescente do Estado de São Paulo (CONDECA), além dos patrocínios oriundos de empresas privadas (nacionais e internacionais).

O projeto tem como objetivo geral promover a formação musical básica e intermediária dos alunos e, por meio do curso, a inclusão social e a cidadania, valendo-se, para isso, de “[ [...] um espaço de referência e de participação, de relações de afetividade e respeito, e que possam garantir a ampliação de seu universo de trocas culturais, o acesso a novos conhecimentos e à experimentação da participação na vida pública", conforme consta no material de apresentação de seu website. Quanto aos objetivos específicos, foram listados os seguintes:

i. Iniciar à prática instrumental e/ou vocal;

ii. Desenvolver habilidades perceptivas, motoras e expressivas;

iii. Enfatizar a música popular brasileira;

iv. Conhecer e experimentar a música popular de outros países;

v. Proporcionar prática musical coletiva;

vi. Favorecer o acesso às escolas de aprofundamento musical;

vii. Apresentar espetáculos musicais na comunidade e em eventos culturais da região;

viii. Facilitar os meios de profissionalização musical aos interessados;

ix. Promover o protagonismo juvenil estimulando para que sejam multiplicadores do conhecimento na comunidade.

A escola de música tem como principal referência de seu trabalho a banda de alunos, criada quando as atividades de musicalização infanto juvenil ainda eram ministradas dentro da sede da ONG. Atualmente, a banda de alunos conta com cerca de trinta adolescentes matriculados no projeto, que possui um histórico com mais de trinta apresentações realizadas na região de Pedreira, em eventos e apresentações culturais em espaços como o SESC e o CEU local, além de salões nobres como o da Câmara Municipal de São Paulo, chegando a realizar apresentações 
musicais para um público com cerca de 3 mil pessoas. A banda também contou com o intercâmbio cultural de artistas nacionais e internacionais da música popular, com os quais também fez apresentações e concertos, participou em programas televisivos e de rádio e na abertura de importantes eventos sociais, além disso, possui músicas de própria autoria. Quanto ao material audiovisual disponibilizado no website do projeto, o grupo musical exibiu performances com releituras de importantes músicas do repertório brasileiro, dentre elas: Anunciação, de Alceu Valença; Lamento sertanejo, de Gilberto Gil e Dominguinhos; e Berimbau, de Baden Powell e Vinícius de Moraes. Contam ainda com estrutura de estúdio e de palco, som e iluminação de alta qualidade para algumas dessas apresentações.

\section{Observacões de campo}

Ambientação

Da Marginal, no sentido Parelheiros, e, depois, Pedreira, a paisagem urbana troca pouco a pouco os arranha-céus espelhados pelos prédios comerciais baixos e pelos imóveis residenciais. Em algumas ruas, largas e bem pavimentadas, há casas espaçosas e calçadas arborizadas e, em uma delas, encontra-se a escola de música; logo abaixo, ainda na mesma rua, a ONG responsável por esse projeto de educação musical. Essa região é contornada por um trecho da represa Billings que, pela água vasta e pelas margens verdejantes, dá a sensação de não mais estarmos na grande metrópole de São Paulo, parecendo mais um bairro de uma cidade do interior: menos tráfego de carros e de pessoas. Ao mesmo tempo que, de maneira brusca, entre uma rua e outra, a paisagem quebra-se e abre-se em uma bricolagem de jornal: ruas estreitas, fuligem, alguns grafites nos muros descascados, casinhas espremidas umas às outras, expostas em seus tijolos cor de terra queimada. De onde se via, a sensação era de uma quentura boa e tranquila, mas, junto a ela, foi-se notando também surgir um sutil estado de alerta e um certo medo que não vieram daquela cena, mas dos pressupostos que guardamos sem se aperceber. Uma imagem de jornal sobreposta ao que se via no presente daquele dia. Nenhuma situação real havia acontecido para justificar tais desconfortos, apenas pressupostos e, em seguida, desconcerto.

A escola de música, por sua vez, cenário vivo desta pesquisa, tem a sua sede em uma casa amarela: ampla, com varanda, canteiros de flores, diversos cômodos distribuídos em dois andares. A casa é colorida por dentro, cheia de música, de crianças e jovens que ocupavam todos aqueles espaços possíveis. As paredes têm pintura nova e trabalhadas em detalhes, cômodos bem 
alocados, com cores radiantes e vibrantes (vermelho, branco, amarelo, azul); telas grandes e coloridas de um expressionismo abstrato à la Pollock, pintadas por seus alunos, dispostas como em uma exposição de arte permanente. Em alguns desses lugares, há também fotografias emolduradas de algumas das apresentações e shows da banda dos alunos da escola e pôsteres autografados por cantores (brasileiros e internacionais) que fizeram algum trabalho em parceria com eles. Havia livros de música popular, de música instrumental, de folclore brasileiro organizados em pilhas nas estantes e nas mesas - um livro aberto em uma página com uma fotografia de Stevie Wonder ao lado de um cd de Mozart -; havia também partituras, apostilas didáticas e colunas de cds sobre as mesas da sala principal, da secretaria e nas salas de aulas. Os móveis são coloridos, feitos de madeira de demolição, os utensílios e decoração eram visivelmente novos e bem cuidados. Havia também uma copa aconchegante, onde tinha café passado, potes de bolachas de maisena e de água e sal ou pão de mel Panco e algumas frutas a disposição de quem ali estivesse (alunos, professores ou visitantes).

De qualquer canto para um outro, as portas e janelas encontravam-se geralmente abertas, arejando e iluminando todo o interior da casa, fechando-se apenas aquelas dos lugares onde estavam a acontecer alguma aula ou ensaio. Dava para ver lá de fora, e de fora, lá dentro; as pessoas transitavam por lá e cá. Mais aos fundos, há um estúdio de música, onde os ensaios da banda dos alunos são realizados, sua estrutura é semelhante à qualidade de um estúdio de música profissional: com isolamento acústico, uma grande diversidade de instrumentos (cordas, sopros, metais, percussão) novos à disposição dos alunos, painel de controle de som, microfones, fones de ouvido, cabos, pedestais para microfone, monitores de estúdio, etc.

Os sons dos instrumentos, as vozes, risos e as conversas despreocupadas ocupam a escola inteira. A música se faz presente nas aulas, em seus espaços formais e, também, espontaneamente em seus interiores cotidianos. A música revestia, sutil, presente, até as entrevistas, entre uma pergunta e outra, enquanto, durante a fala dos entrevistados, melodias surgiam tímidas, arranhadas, nascentes, desajeitadas, em pequenas partes, pouco harmoniosas, vindas de alguma aula de instrumento ou de prática de conjunto musical.

Em um dos dias, observou-se um aluno dedilhando tranquilamente o seu violão no sofá da sala da recepção, parecia que estava na sala de sua própria casa, íntimo e à vontade naquele lugar, esperando a sua aula começar, próximo a uma porta aberta, que dava para fora e se via na presença colorida de arbustos e lindas flores vermelhas em contraste com a parede amarela do 
quintal. No salão central, crianças encontravam-se dispostas em um semicírculo, em volta do professor de canto, atentas (quando não, curiosas com a nossa presença) aos seus movimentos de regência, arranjando a tessitura de suas vozes durante uma aula de coral. Mais à frente, na secretaria, além das já conhecidas cores e conteúdos musicais ali dispostos, havia um enorme cronograma de papel colado à parede, com toda a sequência organizada de atividades da escola de música para o semestre por diferentes cores e legendas; na estante ao lado, inúmeras pastas onde eram guardadas as fichas dos alunos matriculados. A escola de música é também uma casa.

\section{Atividade de prática de conjunto}

Em uma das aulas assistidas, atividade de prática de conjunto, a sala era pequena. Nela, tinham um teclado, um pequeno tambor duplo, alguns xilofones e um violão, instrumento utilizado pelo professor para conduzir a prática. As crianças presentes deveriam ter entre 8 e 10 anos de idade, havendo cinco crianças ao todo (três meninas e dois meninos): uma das meninas estava no teclado; as demais, sentadas no chão, tocando os xilofones; um dos meninos estava com o tambor, também sentado no chão; o outro, encostado à parede, próximo à janela - ele era o vocalista naquela atividade. O grupo estava ensaiando uma música escolhida pelas próprias crianças - "Linda Juventude", da banda 14 Bis - para uma apresentação que iria acontecer em breve. As crianças, que pareciam à vontade com o professor, ficaram um pouco tímidas e curiosas com a minha presença. A prática seguia sem tantas formalidades, com uma relação harmoniosa entre eles, havia proximidade e tranquilidade. Vez ou outra, o professor se voltava especialmente a uma das crianças para corrigi-la e instruí-la e logo em seguida voltava para o arranjo coletivo; de vez em quando, pedia para ensaiar um trecho específico da música. Simultaneamente, enquanto a prática acontecia, nos momentos quando o professor se voltava a um dos alunos, as outras crianças conversavam entre si sobre assuntos outros e, logo depois, quando o professor voltava a tocar a música em seu violão, sem ele mesmo ter que chamar a atenção, elas voltavam para seus instrumentos. Já mais para o final da atividade, a secretária da escola entrou na sala e chamou uma das alunas, pois ela era uma das aniversariantes do mês e iriam cantar "parabéns" para ela. A intromissão pouco perturbou o grupo, a dinâmica entre as atividades formalizadas do programa da escola e esses burburinhos cotidianos parecia muito orgânica. Depois de um breve tempo, a menina retornou à sala com um embrulho colorido nas mãos - havia ganhado um presente de aniversário, o que chamou a curiosidade dos demais alunos 
-, abriu ainda lá, era uma caixa de bombons, e ela sorriu. O professor continuou com a aula, ainda fez algumas correções, voltou em algumas partes da música e indicou algumas mudanças e reforços a serem feitos pelo grupo até o dia da apresentação. Finalizou a aula, pedindo às crianças que apenas cantassem todas juntas o refrão da música, ficou bonito, o vocalista fechava os olhos enquanto cantava:

Zabelê, Zumbi, Besouro

Vespa fabricando mel

Guardo teu tesouro

Jóia marrom

Raça como nossa côr...

Nossa linda juventude

Página de um livro bom

Canta que te quero

Cais e calor

Claro como o sol raiou

Claro como o sol raiou...

\section{Ensaio do coral infantil}

Às quartas-feiras, pela manhã, a escola de música iniciou suas atividades com a prática do coral infantil e, em seguida, aula de teoria musical com as crianças mais velhas. Neste dia, em especial as crianças estavam ensaiando algumas canções para um apresentação em data próxima. Havia, naquele dia, um grupo de dezenove crianças, com idades variadas (entre 8 a 15 anos), com a presença predominante de meninas. Dentre as primeiras constatações ali realizadas, foi percebido imediatamente a presença predominante de crianças negras e pardas.

Quanto à dinâmica do ensaio, as crianças estavam dispostas em duas filas: as crianças menores na frente e as maiores ao fundo. Ao mesmo tempo, os alunos e alunas estavam em uma sequência de tal modo que atendesse à proposta musical do coral, marcada pela sobreposição de vozes. O professor estava à frente, ora assumindo papel de regente, ora fazendo a marcação das músicas com o uso de um teclado, ora com o uso de um violão clássico. O coral ensaiava três músicas para a apresentação, duas delas em inglês. Apesar do engajamento expresso do professor durante o ensaio do coral infantil, o grupo de crianças não estava muito coeso e totalmente voltado para a atividade. Algumas crianças demonstraram pouco ânimo e interesse, houve uma 
série de momentos de distrações e interrupções com as chamadas de atenção do professor para que elas voltassem a se envolver na atividade. Durante todo o ensaio, houve bocejos, conversas paralelas, sussurros, espirros encenados. Havia uma menina em particular, que deveria ter cerca de 11 anos, que, naquele dia, demonstrou pouca empolgação com a atividade, querendo se sentar repetidas vezes e insistindo em descer para poder beber água, além de puxar conversa com outros alunos durante o ensaio. O professor, em alguns momentos, demonstrou irritabilidade, mas conseguiu contornar as distrações de seus alunos. Repetiu algumas vezes que, assim como no ensaio, no dia da apresentação não poderiam se sentar quando bem quisessem, que era momento de trabalhar a voz e as canções, pois, se relaxassem, eles não saberiam como fazer no dia da apresentação, por mais que achassem que conseguiriam. Por outro lado, enquanto cantavam as músicas, os alunos se mostravam muito bem afinados e havia um diálogo musical harmônico com seu professor. As meninas mais velhas pareciam mais determinadas e envolvidas com o ensaio, e também os meninos mais novos, que, na fileira da frente, também divertiam-se com alguns passinhos combinados entre si.

De maneira geral, foi observada uma atividade mais técnica, voltada à afinação das vozes, aos seus arranjos e sobreposições, bem como ao cuidado com a harmonia e com a parte melódica da música. A sensação era a de que estava a se construir uma estrutura musical coletiva para uma música nascente, condições para que ela pudesse se apresentar em público.

\section{$\underline{\text { Entrevistas }}$}

Como parte importante desta pesquisa, foram realizadas cinco entrevistas com alguns dos integrantes da equipe de profissionais responsáveis pela criação da escola de música e de seu respectivo projeto de educação musical. Dentre eles, foram entrevistados a presidente da ONG, a coordenadora pedagógica, a assistente de coordenação e dois professores de música. Conforme a tabulação dos dados coletados, estes foram organizados por sub temáticas que serão apresentadas a seguir.

\section{Formação profissional}

Os profissionais entrevistados fazem parte da escola de música desde sua criação e todos eles contribuíram com a organização do planejamento político-pedagógico do projeto, em 
especial a coordenadora pedagógica. Dois deles são residentes de Pedreira, um dos quais, inclusive, foi atendido pela ONG quando criança; os demais não tiveram laços anteriores.

$\mathrm{Na}$ tabela abaixo, seguem os dados referentes à ocupação/papel de cada entrevistado dentro do projeto da escola de música e à formação profissional de cada um:

\begin{tabular}{|c|c|c|c|c|}
\hline Entrevistado(a) & Idade & Sexo & Ocupação profissional & Formação profissional \\
\hline A & $\begin{array}{l}38 \\
\text { anos }\end{array}$ & Feminino & $\begin{array}{l}\text { Coordenadora pedagógica e } \\
\text { professora de canto. }\end{array}$ & $\begin{array}{l}\text { Formação em canto e } \\
\text { regência; } \\
\text { Pós-graduação em } \\
\text { projetos sociais e } \\
\text { culturais; } \\
\text { Especialização em voz; } \\
\text { Mestre na área de } \\
\text { Fonoaudiologia em voz } \\
\text { cantada. }\end{array}$ \\
\hline B & $\begin{array}{l}55 \\
\text { anos. }\end{array}$ & Masculino & $\begin{array}{l}\text { Professor de música (violão, } \\
\text { teclado, musicalização infantil } \\
\text { e de prática de conjunto); } \\
\text { Membro da banda dos alunos. }\end{array}$ & $\begin{array}{l}\text { Formação em violão } \\
\text { erudito pela OLM; } \\
\text { Graduação em Artes. }\end{array}$ \\
\hline $\mathrm{C}$ & $\begin{array}{c}52 \\
\text { anos. }\end{array}$ & Feminino & $\begin{array}{l}\text { Presidente da ONG; } \\
\text { Responsável pelas funções } \\
\text { administrativas e de captação } \\
\text { de recursos; } \\
\text { Desenvolve atividades de artes } \\
\text { plásticas com os alunos. }\end{array}$ & $\begin{array}{l}\text { Formação em Direito } \\
\text { pela Universidade de } \\
\text { São Paulo (USP). }\end{array}$ \\
\hline $\mathrm{D}$ & $\begin{array}{c}23 \\
\text { anos. }\end{array}$ & Feminino & $\begin{array}{l}\text { Assistente de coordenação } \\
\text { (responsável pelo atendimento } \\
\text { dos professores, alunos e do }\end{array}$ & $\begin{array}{l}\text { Formação } \\
\text { Pedagogia. }\end{array}$ \\
\hline
\end{tabular}




\begin{tabular}{|c|c|c|c|c|}
\hline & & & $\begin{array}{l}\text { público em geral e, também, } \\
\text { realiza parte do trabalho } \\
\text { administrativo). }\end{array}$ & \\
\hline $\mathrm{E}$ & $\begin{array}{c}47 \\
\text { anos. }\end{array}$ & Masculino & $\begin{array}{l}\text { Regente de coral infantil, } \\
\text { juvenil e da terceira idade; } \\
\text { Professor de teoria musical } \\
\text { (estruturação musical } \\
\text { melódica), de musicalização } \\
\text { infantil, contrabaixo, violão e } \\
\text { de canto; } \\
\text { Membro temporário da banda } \\
\text { dos alunos. }\end{array}$ & $\begin{array}{l}\text { Formação em } \\
\text { licenciatura e formação } \\
\text { musical pela } \\
\text { Universidade Estadual } \\
\text { de São Paulo (UNESP). } \\
\text { Formação em canto e } \\
\text { regência em coral; } \\
\text { Instrumentista (violino, } \\
\text { contrabaixo e piano). }\end{array}$ \\
\hline
\end{tabular}

\section{Compreensões sobre arte}

A arte, portanto inclusive a música, foi compreendida de modos bastante diversos entre um entrevistado e outro - algumas concepções apresentaram noções mais formalizadas, outras não, utilizando-se noções mais genéricas e particulares. Mas em todas elas a arte foi caracterizada, principalmente, pelo seu caráter de expressividade: um meio possível para se dar vazão às emoções profundas e voz tanto aos pensamentos como aos sentimentos pessoais e coletivos. Acabou também sendo compreendida, nesse sentido, como "um canal de escape" (A, entrevista 1, Anexo D), tal como apontou uma das entrevistadas, servindo como "uma válvula para se livrar das tensões" (B, entrevista 2, Anexo D), como afirmou outro entrevistado. E, uma vez que isso se dá por meio da estética, formas sensoriais concretas, a arte acaba por ser uma oportunidade de comunicação, segundo eles. Além disso, foi conferido à arte um caráter de socialização e desenvolvimento individual, em que a relação com ela permite a identificação com aquilo que se aprecia esteticamente, bem como possibilita encontros, interações e trocas. Vinculada à possibilidade de expressão, a arte foi encarada como campo de formação e transformação do indivíduo, no que se refere, por exemplo, ao desenvolvimento de sua autoestima, da sua capacidade de enfrentar as adversidades da vida, da sua capacidade imagética e de formação de senso crítico. E como a relação com as diferentes modalidades artísticas requer 
um conhecimento formal e técnico, a interação com a arte apresenta uma potencialidade para o crescimento do indivíduo, segundo um dos entrevistados:

“[...] o que acho bacana da arte é que você traz para fora um crescimento muito interessante, porque você trabalha o seu cérebro inteiro para fazer a arte: você tem que ser preciso, você tem que ser técnico e, ao mesmo tempo, você vai dar vazão às sua emoções, você vai colocar a sua expressividade, você vai colocar as sua emoções. Não é um piloto automático!" (E, entrevista 5, Anexo D).

Por fim, a arte foi compreendida como algo essencial para a vida humana frente a uma realidade social repleta de tensionamentos. Para uma das entrevistadas, "a arte é o respiro do existir, a arte é o respiro da humanidade" (A, entrevista 1, Anexo D), em concordância, para outra entrevistada, ela "é uma alimentação pra alma, em todas as suas linguagens" (C, entrevista 3, Anexo D).

No material coletado, foi observada a articulação entre as compreensões sobre o que é arte e as perspectivas sobre o território periférico. Tal como foi afirmado pela presidente do projeto, o acesso à arte e à cultura são direitos universais, porém não são respeitados ou garantidos pela sociedade brasileira, em especial, pelas entidades públicas no contexto específico das periferias, tendo-se como justificativa a carência de equipamentos públicos destinados a essas esferas de conhecimento e de formação cultural. Ao mesmo tempo, foi identificada uma perspectiva geral acerca do repertório cultural (em especial, o repertório musical) das pessoas residentes desses territórios: considerado limitado, pouco rebuscado, gostos musicais mais simples e vulgares. Fala-se como se isso dependesse tão somente das condições oferecidas pelas instâncias governamentais responsáveis, somado à perspectiva de uma realidade violenta, de pobreza, de carência e de poucas oportunidades acerca das periferias, onde "a cultura não chega, não há espaço" (C, entrevista 3, Anexo D). Diante desse cenário, foram identificadas falas transversais nas quais se pode verificar como um dos sentidos propostos para a educação musical do projeto social em questão o de suprir as necessidades e direitos não garantidos pelo Estado, bem como de prover condições para que os alunos tenham um espaço de acolhimento (até mesmo, de acordo com a fala de um dos entrevistados, como um "espaço de fuga"), no qual, por meio da música, possam exprimir suas tensões, seus sentimentos e dificuldades que, segundo a perspectiva dos educadores, são decorrentes da realidade de vulnerabilidades vivenciadas por essas crianças e 
adolescentes. Para os entrevistados, se a arte se faz necessária a toda humanidade, como um respiro frente a realidade hostil e repressora, na periferia ela é emergencial.

\section{Educação musical}

\section{Princípios e valores do projeto}

De acordo com os entrevistados, a escola de música, enquanto projeto social, ainda não apresenta princípios, valores e missões formalmente instituídos pelo fato de ainda ser relativamente nova; até o momento da realização das entrevistas, o seu estatuto estava em processo de elaboração e formalização. Por outro lado, em todas as entrevistas, foi elencado um conjunto de valores e princípios informais e também de alguns já propostos pela ONG. Dentre eles, foram citados: os direitos humanos básicos; o respeito; o amor; a ambientação familiar; a amizade; o cuidado mútuo; a coletividade; a autonomia; o bom comportamento; a disciplina; o comprometimento; a dedicação; a "promoção de uma cultura da paz"; a verdade; a boa convivência; o acolhimento, tendo-se como uma das missões a de "formar jovens, adultos, crianças para que sejam ativos na sociedade, que saibam defender seus pontos de vistas, que não tenham medo de se expressar" (D, entrevista 4, Anexo D).

$\mathrm{Na}$ maioria das entrevistas, como justificativa desses princípios e valores, a educação musical é encarada como meio possibilitador do desenvolvimento humano de modo a contribuir para a formação da autonomia e da cidadania ao invés do ensino isolado do conhecimento formal de música (teórico e técnico). A musicalização do indivíduo exige dele uma conduta social por meio da qual seja possível a criação e a expressividade musical individual e coletiva, bem como, para isso, uma boa condução da técnica.

\section{Objetivos}

A partir dos dados encontrados, a educação musical encontra-se relacionada, principalmente, aos objetivos de musicalização, de socialização, de formação de cidadãos, formação cultural, de profissionalização e da replicação da educação musical em outros projetos sociais e instituições educacionais. Nas falas de todos os entrevistados, tais objetivos aparecem sobrepostos e articulados com suas perspectivas quanto às demandas comunitárias e familiares de seus alunos. De acordo com eles, frente a uma realidade de carências e de vulnerabilidades, esse projeto social busca gerar oportunidades para essas crianças e adolescentes, seja pelo acolhimento 
afetivo, seja por propiciar um espaço seguro de convivência, seja pela democratização de uma educação musical "de excelência", seja pelo acesso à cultura por meio de passeios e viagens, seja pela "ampliação do repertório musical" de seus alunos, seja pela profissionalização e pela possibilidade de entrada no mercado do trabalho, para além do processo de musicalização, proficiência e formação cultural.

No tocante à formação do indivíduo em específico, em consonância com a compreensão da música enquanto campo de saber artístico envolvido no processo de desenvolvimento de capacidades cognitivas, é atribuído à educação musical o objetivo de contribuir para a formação e para a maturação de etapas do desenvolvimento intelectual das crianças e adolescentes assistidos, vinculando-o ao objetivo de propiciar experiências positivas e satisfatórias e à possibilidade de profissionalização. Para a presidente da ONG:

[...] a música na infância, a gente sabe que é fundamental para a formação do ser humano, para a capacidade de interpretação das situações, da formação até da inteligência e das percepções de raciocínio. [...] pode se tornar uma profissão ou um momento bonito e importante que tiveram na vida, que curtiram, que agregou, que foi em grupo, que tiveram a oportunidade, que tiveram a experiência e que foi bem feliz na vida deles, né. Então, a gente quer deixar momentos felizes e criar oportunidades profissionais também $(\mathrm{C}$, entrevista 3 , Anexo D).

Em contiguidade a isso, busca-se também colaborar, por meio da educação musical, com um processo "transformador" desses indivíduos, por meio do qual os alunos desenvolvam um "bom caráter", consigam expressar seus pensamentos e sentimentos, desenvolver uma boa capacidade de comunicação, fortalecer sua autoestima, bem como lidar com as adversidades vividas, tal como é explicitado na fala a seguir:

Na verdade, eu acho que a escola, como um dos seus objetivos, tem como uma das funções que é a música e com ela, em si, promover transformações de caráter, não só a técnica da música, entendeu, que eles tenham domínio técnico do instrumento, que eles aprendam técnicas vocais, mas que a música, de certa forma, influencie dentro da casa deles, na família, no convívio social deles (D, assistente de coordenação, entrevista 4, Anexo D).

\section{Planejamento pedagógico}


No que diz respeito ao planejamento pedagógico, as atividades propostas são as de ensino e prática instrumental (sopros, cordas e percussão); aulas de canto e de coral; e de expressão corporal, privilegiando-se o repertório musical da música popular brasileira e internacional. Além disso, também são propostas outras atividades culturais, tais como viagens, passeios, shows, oficinas e workshops. O sistema de ensino-aprendizagem é fundamentado, principalmente, pelo modelo pedagógico T.E.C.L.A., desenvolvido pelo educador musical britânico Keith Swanwick, cujo trabalho incorpora algumas das formulações piagetianas, tendo como princípio norteador de sua pedagogia a compreensão de que qualquer conhecimento deve obedecer às etapas do desenvolvimento psicológico de quem o estuda, processo que deve estar articulado, por sua vez, com o desenvolvimento da criatividade. Para isso, esse modelo pedagógico foi estruturado nas seguintes etapas:

T - técnica (manipulação de instrumentos, notação simbólica, audição);

E - execução (cantar e tocar);

C - composição;

L - literatura (história da música);

A - apreciação (reconhecimento de estilos/ forma/ tonalidade/ graus).

Dentro desta proposta de ensino, a técnica, a execução e a composição foram eleitos como os principais componentes do planejamento pedagógico, sendo, assim, "um tripé que sustenta o restante" (A, coordenadora pedagógica, entrevista 1, Anexo D). Pretende-se, por meio disso, privilegiar o desenvolvimento da criatividade e da proficiência, em detrimento da reprodução técnica musical, para que, de acordo com a coordenadora pedagógica, “[...] não seja uma coisa totalmente quadrada, que eles só aprendam a nota no pentagrama e que sejam reprodutores, máquinas, reprodutores daquilo que estão aprendendo, mas eles também são estimulados a criar, a improvisar" (A, coordenadora pedagógica, entrevista 1, Anexo D).

A escolha deste método de ensino musical se deve, entre outros motivos, pelo fato de ele ser muito estudado em pesquisas e adotado em diversos trabalhos de educação musical, propiciar certa liberdade e flexibilidade de trabalho ao educador e, sobretudo, pelo fato de ser um método que privilegie o desenvolvimento do entendimento do conhecimento musical, em detrimento de um sistema de ensino-aprendizagem baseado na reprodutibilidade técnica. 
Outros trabalhos de pedagogia musical como os desenvolvidos por Carl Orff e Zoltán Kodály também são referências adotadas no planejamento pedagógico desse projeto. Além deles, trabalhos de referência no meio musical, como festivais internacionais de coros e de música orquestrada, também são tidos como parâmetro.

Com base na pedagogia de Swanwick, o programa tem duração mínima de três anos, com carga horária de 18 horas mensais, com atividades semanais, organizadas semestralmente: no primeiro semestre, o programa básico semanal consiste em aulas do instrumento principal, instrumento complementar, coral (solfejo melódico) e prática rítmica; nos demais semestres, são realizadas as aulas do instrumento principal, instrumento complementar, linguagem e estruturação musical e prática de conjunto. A escolha dos instrumentos (principal e complementar) a serem ensinados se dá de acordo com a preferência dos próprios alunos, dentro das opções disponibilizadas pela escola, buscando responder ao sentido de complementaridade (um instrumento harmônico e um instrumento percussivo, por exemplo), contando também com o auxílio da própria equipe de educadores. O programa geral para as aulas transversais (aulas de estruturação musical, aulas de prática de conjunto, teoria musical e teoria rítmica) foi organizado pela coordenação pedagógica em conjunto com os demais educadores, enquanto os programas voltados para as aulas de instrumentos foram preparados por cada professor responsável pelo instrumento, cujos programas foram estruturados com base na principal pedagogia musical adotada pela escola.

De acordo com os entrevistados, para o cumprimento das atividades pedagógicas elaboradas pela equipe, em diálogo com o método pedagógico adotado, busca-se também valorizar e incluir o discurso dos próprios alunos, levando em consideração o seu contexto comunitário e sua realidade familiar. A educação musical proposta nesta instituição se dá também a partir da consideração do gosto musical dos alunos, por meio do qual os educadores introduzem conhecimentos sobre formas e cadências, ao mesmo tempo em que também buscam, por outro lado e a partir disso, "instigá-los" para conhecerem outros estilos e repertórios musicais por eles considerados mais "formais", "ricos" e "elaborados". Conjuntamente a isso, é considerada a singularidade de cada aluno quanto à sua relação com as atividades propostas (em especial, com os instrumentos musicais), visando-se melhor colaborar com o processo de habilitação musical de cada um, buscando-se respeitar suas dificuldades de aprendizagem, bem como motivar o desenvolvimento de suas potencialidades criativas, expressivas e musicais. Tal como expõe um 
dos professores de música entrevistado, "a gente vai trabalhando conforme onde ele (aluno) está, no nível que ele está; a gente não tenta interferir, fazer ele se encaixar no esquema, a gente tenta pegá-los no ponto onde eles estão e conduzi-los para fazer as atividades" (B, entrevista 2, Anexo D).

Para conferir se o planejamento anual está sendo cumprido, os educadores musicais elaboram relatórios mensais, nos quais descrevem quais foram as atividades realizadas (aulas, apresentações, participação em eventos culturais, workshops, ensaios, etc.) e, a partir deles, a coordenação pedagógica avalia o andamento da educação musical proposta. Entretanto, com base na análise horizontal das entrevistas, foi identificado um dado discrepante referente à frequência de reuniões de equipe (formais ou informais) para se pensar, avaliar, discutir e revisar a qualidade do planejamento pedagógico. De acordo com a coordenadora pedagógica, a "roda de conversa" e "as trocas de idéias" são recorrentes para que os educadores "[...] tenham espaço, inclusive, para reformular e seguir outros caminhos, se eles acharem necessário” (A, entrevista 1, Anexo D), enquanto que, em outras duas entrevistas, essa informação é contraposta em decorrência da carga de trabalho exigida diariamente:

[...] quando tem reunião, a gente fala, mas não dá para fazer muita reunião, porque o movimento é bem..., a gente trabalha até de sábado com a banda (B, professor de música, entrevista 2, Anexo D).

[...] foram ainda poucas reuniões. A gente ainda..., não foi o suficiente. E nas demais horas, a gente trabalha muito e, às vezes, não sobra tempo para falar sobre outras coisas (D, assistente de coordenação, entrevista 4, Anexo D).

Em relação aos alunos, eles são consultados quanto às atividades desenvolvidas através de relatos pessoais - sobre como se sentiram vendo um espetáculo, um concerto ou um show, por exemplo - na forma de poemas e redações, que, de acordo com a assistente de coordenação, "é uma forma de saber o que eles estão achando" (D, assistente de coordenação, entrevista 4, Anexo D).

\section{Formação cultural}

Quando indagados sobre a possível relação entre educação musical e formação cultural, essa ficou muito atrelada à possibilidade de "formar bons seres humanos", em seu sentido mais amplo de cidadania e de autonomia. Foi destacado o processo de desenvolvimento e de 
transformação da relação dos alunos com a música: o tipo de escuta; o gosto musical; o interesse em assistir a concertos e apresentações musicais variadas; a curiosidade em conhecer outros estilos musicais e a capacidade de analisar e fazer críticas musicais. Para a coordenadora pedagógica, por exemplo, isso é observado pelas “[...] associações que eles fazem, os interesses que eles têm, as conexões que eles estabelecem" (A, entrevista 1, Anexo D). A capacidade de compreender a música, o seu sentido estético, por meio da apreciação orientada dentro do contexto da educação musical, encontra-se, inclusive, alinhada à proposta metodológica de ensino adotada, buscando, assim, contribuir para a formação de um senso crítico de seus alunos.

A formação cultural apresentou-se atrelada também ao desenvolvimento de determinadas capacidades de socialização e ao desenvolvimento individual, principalmente no que se refere às dificuldades de comunicação, expressividade, reconhecimento e autoestima, e que muitas delas vão sendo superadas pouco a pouco por meio da música e da musicalização. Segundo consta em alguns dos trechos das entrevistas realizadas:

[...] as dificuldades que, às vezes, eles tinham de falar, alunos muito tímidos de conversar entre si, mas que quando cada um pega seu instrumento, você vê um diálogo imenso acontecendo ali o tempo inteiro. Um diálogo familiar que você vê por vezes, assim, a mãe que vai na escola e só ouve reclamação do filho que não tem um bom comportamento, que não tira nota boa em matemática e, de repente, a mãe vê o filho no palco e sendo aplaudido de pé, e ver o filho cantar. Mas acho que essa formação cultural está muito além, acho que é a formação cultural deles mesmo e de todo o entorno (A, coordenadora pedagógica, entrevista 1, Anexo D).

[...] eu vejo a música, quando você entra e permite trabalhar com ela, ela tem uma função transformadora muito grande. Vale lembrar que, assim como toda produção artística, ela pode ter várias finalidades de uso: benéficas e nocivas. Há registros de que na época do nazismo, se usava música como método de tortura. Mas, a gente busca a música como oportunidade de transformação, oportunidade de crescimento, de entrega e de disciplina. São tantos benefícios que ela traz e que vão ajudar nessa construção do ser humano. Então, ela vem como que uma abertura de portas e mostra para pessoa o quanto ela é capaz de se superar, de se apresentar em público, de subir num palco e de se apresentar a uma platéia, um teatro lotado. Então, assim, uma grande oportunidade de transformação humana (E, professor de música, entrevista 5, Anexo D).

\section{Perspectivas sobre o público atendido}

Em todas as entrevistas, os alunos desta escola de música e residentes da comunidade periférica local foram caracterizados, em sua maioria, como pessoas vivendo situações cotidianas 
de precariedade e violência; com famílias desestruturadas e carentes de afeto; com poucas oportunidades (de educação, de trabalho, de lazer, por exemplo); com repertório cultural limitado e com poucos recursos para ter acesso a outros repertórios considerados mais elaborados e rebuscados. Quanto às suas preferências musicais, elas foram caracterizadas de modo pejorativo como gosto musical "simples", "limitado" e "vulgar", sendo citado o funk como o principal exemplo. Além disso, os alunos também foram caracterizados como crianças emocionalmente fragilizadas, com dificuldades de se expressarem, de se colocarem, de emitir uma opinião ou pensamento, de se sentirem pertencentes a um grupo, de reconhecerem seus direitos, com "sonhos estacionados" e com baixa estima; ao acompanhá-las durante a realização do curso, os entrevistados disseram perceber certas inquietações, tensões e ansiedades, as quais consideram serem decorrentes do ambiente familiar e do tipo de relações lá estabelecidas. Essa perspectiva comum entre os entrevistados, por sua vez, foi também por todos eles diretamente relacionada ao contexto territorial das periferias, em que a região periférica da extrema zona sul de São Paulo em específico foi descrita como uma área violenta, dominada pelo tráfico de drogas e em situação de alta vulnerabilidade social. Abaixo, alguns trechos retirados das entrevistadas para ilustrar tais perspectivas:

Sobre a comunidade periférica da extrema zona sul de São Paulo, local de residência dos alunos:

A gente vê, aqui, muitos casos, que nesse bairro aqui é pesado; a gente vê muito alunos que saíram daqui e estão perdidos por aí, e estão pelas ruas. Aqui, você não aprende coisa boa se estiver na rua $(B$, professor de música, entrevista 2 , Anexo D).

[...] a gente está em uma comunidade violenta, né, com diferentes números de problemas ligados à drogas, à álcool, a violência contra mulher também $(\mathrm{C}$, presidente, entrevista 3, Anexo D).

A comunidade é carente, extremamente carente de espaços culturais [...] A gente não consegue nem espaço para apresentar. [...] Outros espaços culturais não têm. Então, a gente se encontra em uma situação extremamente precária, dê ausência de tudo (C, presidente, entrevista 3, Anexo D).

Sobre as relações familiares dos seus alunos: 
[...] a gente tem um ambiente muito familiar aqui, até porque a gente sabe que esse núcleo familiar dos alunos do nosso contexto é muito difícil, né. Então, onde eles possam se cuidar, de amor e de amizade, isso é muito presente aqui (A, coordenadora pedagógica, entrevista 1, Anexo D).

[...] eles têm histórias pesadas em casa e muitas vezes, eles fogem pra cá, né. Tem criança que vem pra cá no sábado e não quer ir embora mais, que chegam em casa e não tem espaço para ficar (B, professor de música, entrevista 2, Anexo D).

A gente está cercado de crianças que têm, assim, muitos problemas de afetividade, ausência de figuras importantes na família, pai, mãe [...] Alunos que a gente sabe que, geralmente, têm mãe, mas que não têm pai, que têm padrasto. A gente sabe que tem situações de violência doméstica de diversos tipos e níveis. Então, são alunos que vêm de um contexto social bem complexo $(\mathrm{C}$, presidente, entrevista 3, Anexo D).

As nossas crianças são crianças da classe baixa, que moram com pais separados, geralmente, a maioria delas, que não tem muito acesso à cultura, nem a lazer, que estudam em escola pública; que vivem em uma casa que não tem uma estrutura familiar legal, que em casa, tem muitas brigas, que a família não se entende, que o pai, por ter que trabalhar para pagar as contas, não tem muito tempo para passear com o filho e que não dá muita atenção para essa criança. Então, é uma criança carente de afeto (D, assistente de coordenação, entrevista 4, Anexo D).

[...] uma vez, eu estava conversando sobre uma aluna e o presidente falou: oh, essa daí, se der uma cesta básica para ela é quase perigoso a mãe vender a cesta básica e trocar por drogas (E, professor de música, entrevista 5, Anexo D).

Sobre o repertório musical dos alunos:

Então, tem sim uma importância, mas a partir do momento que eles experimentam outras coisas, conhecem outras canções, é como se eles estivessem tendo a oportunidade de se projetar em outros lugares que eles não têm (A, coordenadora pedagógica, entrevista 1, Anexo D). 


\section{DISCUSSÃO}

\subsection{A periferia, as perspectivas estereotipadas e as desigualdades sociais}

A realidade de vulnerabilidades e desigualdades sociais, anteriormente apresentada, apesar de estar diretamente relacionada ao tipo de atuação do Estado, é, de modo inverso, associada enfaticamente aos próprios moradores das periferias enquanto responsáveis pela própria condição de precariedade, seja pela compreensão comum, seja pelo discurso das grandes mídias e meios de comunicação de massa, seja até pela produção do conhecimento científico. Ao mesmo tempo, esse conjunto de aspectos negativos é referido com um sentido de totalidade nos mais diferentes discursos, absolutizando-se por vezes pela sua repetição exaustiva e configurando-se, por fim, em uma perspectiva estereotipada generalizada, em detrimento de uma compreensão mais objetiva, que parta da experiência e de um conhecimento mais aprofundado, consistente e fundamentado acerca do dinamismo, da multiplicidade e das contradições que abrigam e organizam uma comunidade, a qual também envolveria o reconhecimento de outros elementos, como aspectos positivos dessa mesma comunidade. Não à toa, os principais bolsões de pobreza das cidades (periferias, morros e favelas) são referenciados, principalmente, pela chancela das vulnerabilidades, da criminalidade, da sua periculosidade, das chacinas, do extermínio, do tráfico de drogas, pela ameaça e pelo medo, enquanto que a alegria presente nas rodas de samba, no tambor de crioula, a ancestralidade africana viva nos terreiros e na capoeira de angola, o protagonismo social, político e cultural dos saraus e das organizações comunitárias, os músicos e poetas que lá residem, a orquestra sinfônica de Heliópolis, a história e a memória desses lugares, as intervenções artísticas itinerantes, a poesia de rua, as danças folclóricas, a discotecagem, o seu próprio repertório cultural e a sua própria voz ainda são menos evidenciadas, reconhecidas e ouvidas.

Entre festividades populares e o novo, como o funk, a discotecagem e a cultura hip hop, e entre as mais diversas formas de organizações culturais e sociais, como os saraus e coletivos culturais, há ações interventivas políticas e culturais, e projetos sociais atuantes nas periferias, cujas práticas colaborativas compõem um novo campo educacional e formativo cultural, que não o das escolas regulares e da educação formal, sendo essas ainda objeto de pouco debate nas grandes mídias e até mesmo na produção acadêmica científica atual, conforme constatado na pesquisa bibliográfica e por outros autores da área. 
A partir da atividade de mapeamento territorial do extremo sul da cidade de São Paulo, pudemos nos aproximar e melhor conhecer o que existe nessas regiões urbanas, destacando-se a diversidade de organizações culturais comunitárias e instaladas nas áreas das periferias correspondentes, e, consequentemente, nos levou a contrapor e a evidenciar alguns elementos do preconceito e da segregação social, bem como a ampliar a compreensão sobre o que vem a ser os territórios periféricos. De acordo com Trotta (2016, p.89), esta fica comprometida pelas concepções atomizadas de "falta", "carência" e "vulnerabilidade", quando, na verdade:

Periferia é uma metáfora geográfica que se refere a todo um conjunto de práticas e valores que circundam o universo popular. Incorpora tanto os habitantes de áreas marginalizadas das grandes cidades quanto suas práticas de consumo, seus produtos, gostos e estilos de vida. Fortemente atravessada por uma interpretação do popular e do periférico como construções operadas a partir da "falta" [...]. (TROTTA, 2016, p. 89)

Para melhor compreender alguns dos elementos estruturantes das relações sociais que levam a produção de concepções costumeiramente negativas e monadológicas em relação às comunidades das periferias e às pessoas que lá vivem recorremos, em um primeiro momento, a algumas das contribuições teóricas de Axel Honneth (2003, 2013), por meio das quais, foi possível fazer uma leitura reflexiva sobre alguns aspectos do processo de socialização e das construções grupais e, inerente a isso, da (pseudo)individuação. Deste modo, essa primeira análise acerca da realidade social das periferias dentro da lógica social de divisão de classes, como também sobre os discursos dominantes e os tipos de relações sociais concernentes, foi sustentada principalmente pelas noções conceituais de reconhecimento recíproco, luta por reconhecimento e direito. Também, buscamos elaborar uma leitura crítica a partir da compreensão conceitual adorniana quanto às formas vigentes da organização social e sua lei objetiva de desenvolvimento.

As comuns perspectivas sociais estereotipadas acerca das periferias estruturam-se por estigmas que se têm sobre essas comunidades: pela estética da pobreza, pela estética da fome, pela estética da violência urbana, pela estética da falta de higiene, pela estética dos barracões e das "barraqueiras" (referência às mulheres das periferias). As quais se reproduzem pelo modo como as periferias são retratadas no discurso das mídias dominantes, nos filmes, nos programas televisivos, nas novelas e, por fim, no senso comum e até mesmo no discurso de muitos 
representantes políticos brasileiros e nos sentidos que orientam determinados tipos de intervenção policial, missionária religiosa, e também de projetos sociais nessas áreas. Perspectivas tais que nos permitem pressupor o atenuamento de uma visão sócio histórica sobre a organização da sociedade, bem como o tipo de concepções componentes de sua eticidade e dos valores sociais hierárquicos imanentes que estão envolvidos e que produzem uma realidade de desigualdades sociais, claramente manifesta pela marginalização social das periferias: geográfica, política, cultural, social e humana. Revelando a fragilidade das relações entre pessoas, da garantia dos direitos básicos às populações marginalizadas e da experiência coletiva no que diz respeito ao cumprimento consistente (solidário, afetivo, institucional e jurídico) do princípio de igualdade universal, não à toa que "[...] na estranheza do povo em relação à democracia se reflete a alienação da sociedade em relação a si mesma” (ADORNO, 2006, p.36).

A estereotipia e a estigmatização social das periferias, e também a não garantia dos direitos básicos dessas comunidades, consistem em algumas das principais problemáticas sociais reclamadas pela parcela da população mais vitimada e por pessoas e organizações solidárias às suas causas. Questões políticas e sociais que são tidas como uma das principais razões precedentes pelas quais foram formados os corpos dos coletivos e movimentos culturais, bem como de muitos dos projetos sociais das periferias da zona sul da cidade de São Paulo. O direito pela sua existência, transformação social, cidadania e inclusão social são os eixos orientadores e os objetivos mais comuns desses movimentos e organizações sociais (GOHN, 2009, 2015; PERES et al., 2018; TOMMASI, 2013). Tal como se pôde observar na descrição dos grupos elencados no mapeamento territorial realizado, todos eles vincularam seus repertórios culturais e estéticos à linha de frente da luta política de enfrentamento e resistência contra a realidade de estigmatização das periferias e de desigualdades sociais sofridas em seus territórios como forma alternativa de superar o silenciamento e o ensurdecimento, socialmente determinados, de suas vozes, de suas estéticas, de suas histórias, memórias e realidades cotidianas: por uma nova ideia de estética periférica. Buscam, desta forma, passar “[...] das páginas policiais pras páginas culturais" (VAZ, COOPERIFA, 2012) das seções dos jornais e, também, em contiguidade, resgatar a autoestima de seus conterrâneos. Movimentos como esses estão aos poucos conquistando visibilidade e estão "ultrapassando as fronteiras geográficas e simbólicas" da cidade (TOMMASI, 2013, p.28). Para Takeuti (2010), a arte e a cultura popular periférica manifestam 
um intento político, visando à ressignificação social quanto às perspectivas dominantes sobre as margens sociais, segundo este autor:

A entrada ao novo milênio começou mostrando uma movimentação inédita em alguns territórios urbanos brasileiros: se, antes, a "periferia" era visível apenas como o lugar da infâmia (violências diversas, crimes, tráfico de drogas...), ela passou a expor também um cenário em que se disseminam inventividades artísticos literários-culturais-esportivos com produções que chegam a escoar para fora dela. Dir-se-ia que se trata de uma expressão de múltiplas singularidades em conexão, realizando movimentos em proliferação que efetivam ultrapassagens de fronteiras. A mise-en-scène de uma arte popular parece produzir desdobramentos peculiares na subjetividade de seus habitantes, os quais passam a ter outras posturas diante das infindáveis dificuldades e dilemas produzidos pela insistente condição de pobreza e miséria (TAKEUTI, 2010, p.14).

Somados a isso, os movimentos e projetos sociais comunitários configuram-se também por um caráter educacional e formativo, o qual, conjuntamente com práticas pedagógicas e atividades político culturais, resulta de uma rede colaborativa e específica de conhecimentos e saberes populares e territoriais. Conforme Gohn (2009), articulam-se como:

[...] novos campos de produção de conhecimento e áreas de saber que estavam invisíveis ou não tratados como conhecimento ou saber educativo - recobertos de práticas pedagógicas e processos educativos. Outras dimensões da realidade social, igualmente produtoras de saber, vieram à tona, tais como as que advêm do mundo das artes, do "mundo feminino" das mulheres, do corpo das pessoas, das religiões e seitas, da cultura popular, das aprendizagens do cotidiano, via a educação não-formal. E estas outras racionalidades estão predominantemente presentes nos trabalhos desenvolvidos no campo da educação não-formal, junto a centenas ou milhares de pessoas que participam de projetos sociais comunitários (GOHN, 2009, p.30).

De modo geral, pouco ainda se conhece a "perspectiva de dentro" (PERIFERIA EM MOVIMENTO, 2009), das pessoas que residem nas periferias, ou ainda, a história, a memória e o repertório cultural são pouco reconhecidos e respeitados em sua complexidade, especificidades e em suas reais potencialidades educativas para a transformação social, por mais que, atualmente, esse quadro venha se modificando e os movimentos culturais das periferias, assim como os seus artistas vêm conquistando e ganhando maior visibilidade que outrora (TOMMASI, 2013). Quanto ao caráter educativo dos projetos sociais, dos movimentos e coletivos culturais, tal como afirma Gohn (2009, p.31), “[...] é uma área que o senso comum e a mídia usualmente não veem e não 
tratam como educação porque não são processos escolarizáveis”. Há, deste modo, uma relação entremeada por uma perspectiva parcial e atomizada, assim sendo, generalizada e estilizada, que, de acordo com Axel Honneth (2013):

Por mais diferentes que pudessem ser essas construções de grupo típicas de cada época, elas se assemelham muito na tendência formal de sempre selecionar um dos possíveis atributos de agrupamentos sociais e estilizá-los como a característica que tudo define. Nas concepções negativas, os traços grupais regressivos, ameaçadores do $\mathrm{Eu}$, foram generalizados a tal ponto que, da multiplicidade de suas manifestações sociais, restou tão somente a tediosa massa, enquanto nas concepções positivas, os elementos civilizatórios, fortalecedores do Eu, foram idealizados a tal ponto que, imperceptivelmente, os riscos da perda de autonomia tiveram que passar despercebidos. Na forma dessas perspectivas unilaterais, tais teorias frequentemente influenciaram a consciência cotidiana comum, ao contribuírem para a formação de mitologias sociais, que logo depois estariam refletidas na literatura ou nos meios de comunicação (HONNETH, 2013, p.59).

São recorrentes as manchetes dos jornais reportarem, por exemplo, a violência nos morros, a guerra do tráfico, as chacinas, a vulnerabilidade social, as carências materiais, a pobreza, etc., nessas áreas, assimilando-as em associações diretas aos próprios moradores, lembrando aquilo pontuado já há décadas: “[...] a posição do indivíduo torna-se assim precária. No liberalismo, o pobre era tido como preguiçoso, hoje ele é automaticamente suspeito." (ADORNO; HORKHEIMER, 2006, p.124). Sendo projetados costumeiros julgamentos monadológicos, referindo-se a eles, em uma assimilação direta, como "bandidos", "criminosos", "ladrões", "traficantes", "sem cultura" ou "sem acesso à informação". Situação generalizada que vem a ser uma expressão evidente da manutenção do medo e da ameaça para além da sua necessidade real de autoconservação, mas como comportamentos economicamente racionais e psíquicos da dominação social (CROCHIK, 2001).

As generalizações populares, midiáticas e até científicas são comportamentos que têm “[...] na sua origem e manutenção essa ameaça e o consequente medo" (CROCHIK, 2001, p.21) em detrimento da própria relação entre indivíduos, uma vez que o desconhecimento, a estereotipia e o preconceito contra essas populações expõem essa não relação, bem com a consciência alienada quanto à complexidade sociológica e psicológica que as forma. O que contribui, em contrapartida com a banalização das outras histórias por detrás da história oficialmente imposta pela razão dominante e ideológica, bem como para manter a estrutura dessa 
realidade de despotencialização humana, exclusão e desigualdade social. Isso impede o conhecimento objetivo, e reforça, por fim, a ideologia da dominação, assim como retroalimenta discursos e consciências alienadas, que concebem o todo dinâmico, histórico e social dessas comunidades tão somente por "[...] um aspecto do fenômeno social” (HONNETH, 2013, p.60).

O gérmen produtor dos estereótipos, preconceitos e estigmas sociais está presente nos elementos do antissemitismo, na perspicácia da indústria cultural e na semicultura, e, consequentemente, na pseudoindividuação: o desenvolvimento de um eu enfraquecido, a regressão do esclarecimento e o medo como meios para a manutenção da dominação, o que é incompatível com a relação humana, no sentido de haver intersubjetividade, em seu lugar, a relação entre indivíduos fechados em uma consciência reificada, determinada por uma lógica exterior a eles. Segundo Adorno:

Pesquisas feitas nos Estados Unidos revelaram que a estrutura da personalidade não se relaciona tanto assim com critérios econômicos-políticos. Ela seria definida muito mais por traços como pensar conforme dimensões de poder impotência, paralisia, e incapacidade de reagir, comportamento convencional, conformismo, ausência de auto-reflexão, enfim, ausência de aptidão à experiência. Personalidades com tendências autoritárias identificam-se ao poder enquanto tal, independente de seu conteúdo. No fundo dispõem só de um eu fraco, necessitando, para se compensarem, da identificação com grandes coletivos e da cobertura proporcionada pelos mesmos (ADORNO, 2006, p.37).

O processo formativo para a emancipação é subtraído pelos mecanismos de manipulação das massas, pela educação domesticada e pela identificação, ordenadas pelas soberania do todo sobre o particular, restritas a uma malha de socialização adaptativa, marcada por renúncias individuais, com fins ilusórios de uma autoconservação quando na verdade a real finalidade extrapola a esta, passa a ser a própria dominação, não necessária à sobrevivência humana mas para a produção capitalista (ADORNO; HORKHEIMER, 2006; CROCHIK, 2001). Em decorrência disso, a racionalidade operante, a racionalidade técnica e a cultura administrada, e seus mecanismos obnubilam tudo aquilo que a ameaça, ou seja, a própria a autodeterminação, a individuação e o pensamento esclarecido, bem como de tudo aquilo que esses processos de formação dependem: liberdade, autonomia, tempo, espontaneidade, relação intersubjetiva e experiências. O que leva, consequentemente, à formação de uma socialização na qual "As relações entre os indivíduos não são relações entre sujeitos - sujeitos de sua consciência, sujeitos 
de sua ação - e, sim, entre mônadas" (CROCHIK, 2001, p.21). Tal impessoalidade, expressão da falência da experiência e do pensamento, acaba por manter a opinião pública afastada do objeto, sua relação é meramente projetiva, na qual tende a haver o deslocamento dos imperativos sociais vigentes e seus respectivos efeitos para a ordem individual, como próprias da "natureza" humana, que, para Adorno e Horkheimer (1973), refere-se à teoria das mônadas, que:

[...] oferece um modelo conceptual para a visão individualista do homem concreto na sociedade burguesa: 'que uma substância particular não atua sobre uma outra e ainda menos a sofre, se considerarmos que tudo o que acontece a cada uma delas é tão-só a consequência da sua idéia ou da sua noção completa, pois essa idéia já encerra todos os predicados ou eventos e expressa todo o universo'. 'As mônadas não têm janelas pelas quais possam entrar ou sair alguma coisa' e as modificações que nelas ocorrem não têm causas externas mas derivam, outrossim, de um 'princípio interno'. Por último, cada mônada é diferente das outras todas. A sociedade será, pois, a soma de indivíduos singulares [...]. (ADORNO; HORKHEIMER, 1973, p. 46, 47)

A tendência característica da sociedade do capital, sociedade de classes, quanto à perspectiva unilateral, ou, à luz da compreensão conceitual frankfurtiana, da perspectiva monadológica, é determinada pela racionalidade objetiva e estratégica da produção econômica, cuja lógica é própria dos negócios, e cujos interesses privados se confundem e se sobrepõem aos interesses e sentidos éticos e humanos de uma coletividade autônoma, tornando-os heterônimos aos próprios sujeitos (ADORNO, 2006; ADORNO; HORKHEIMER, 2006):

\footnotetext{
Que importa do nauta o berço

Donde é filho, qual seu lar?

Ama a cadência do verso

Que lhe ensina o velho mar!

Cantai! que a morte é divina!

(ALVES, 2008, p.16)
}

Para a manutenção da ordem dominante, o princípio de realidade é investido de uma irracionalidade racionalizada, por meio da qual elementos do antissemitismo perduram e justificam-se. Assim como no regime nazista, a violência e o horror assolaram apenas alguns grupos bem definidos e evidenciados pela campanha da destruição enquanto muitos outros viveram das benesses da sua alienação partidária, tal como indicado por Adorno: 
Para um número incontável de pessoas, a frieza do seu estado de alienação parecia eliminada pelo calor do estar em comunidade, por mais manipulada e imposta que fosse esta situação; a comunidade popular dos não-iguais e dos nãolivres, como mentira que era, também era simultaneamente a realização de um sonho burguês antigo, embora desde sempre perverso. (ADORNO, 2006, p.38)

Longe de ser superada, na verdade, ainda somos uma civilização esclarecida para a barbárie, cujo “[...] 'irracionalismo' é derivado da essência da própria razão dominante e do mundo correspondente a sua imagem" (ADORNO; HORKHEIMER, 2006, p.15): o preconceito, o estigma, a opressão, a discriminação e a exclusão social. A periferia é uma das expressões atuais mais evidentes disso, herdeira dos navios negreiros, do tráfico de pessoas negras, do mourão, da casa grande e da senzala:

Senhor Deus dos desgraçados!

Dizei-me vós, Senhor Deus!

Se é loucura... se é verdade

Tanto horror perante os céus?!

(ALVES, 2008, p.23)

Não à toa, é nas bordas sociais, nas grandes periferias, onde se contabiliza os maiores índices estatísticos alvos da violência policial, de população encarcerada, de homicídios, do genocídio negro, de pessoas com empregos subalternos, de moradias irregulares, de esgotos à céu aberto, da quase inexistência de políticas e equipamentos públicos, e para onde pouco se voltam a comoção geral, a empatia e a solidariedade humana. Na periferia acordam mais cedo para servir o café nas padarias do Jardins, de Pinheiros e de Moema. Lavam seus automóveis, limpam suas vitrines, constroem seus edifícios de luxo, cuidam de suas crianças. Tornam-se somente braços e pernas, mãos inchadas, engrenagens da maquinaria, rostos anônimos, pequenos borrões substituíveis. Homens e mulheres que todos os dias descem o morro com suas histórias e viram suco (ANDRADE, 1981), esmagados diariamente, em uma vida-morte-sina, pela hostilidade social, que, como no versinho do personagem-poeta popular Deraldo, “[...] enquanto a fortuna dorme, a desgraça não descansa" (ANDRADE, 1981). Paradoxalmente, sobrevive a imagem contrária, de que "os trabalhadores, que são na verdade aqueles que proveem a alimentação dos demais, são alimentados, como quer a ilusão ideológica, pelos chefes econômicos, que são na verdade os alimentados" (ADORNO; HORKHEIMER, 2006, p.124). 
O silenciamento é previsto, os detalhes da desgraça e a ginga da resistência nas e das periferias são amordaçados pela censura jornalística, pelo estereótipo e pelo descaso social. O estreitamento das perspectivas gerais acerca de suas condições e repertórios é artifício publicitário para salvaguardar o mecanismo operante e inflexível da oferta e da procura e de tudo aquilo que, para isso, ele venha a exigir e a submeter. Isso só é possível em uma sociedade de classes, massificada, não-emancipada, ou seja, somente pela divisão entre dominantes e dominados, pela condição da alienação cultural, papel atribuído às forças produtoras de sentido, de racionalidade, pela ação da indústria cultural. Sob a aparente promessa liberal, faz-se imperar a determinação social à custa da própria vida humana, sobretudo, a dos dominados, que como os próprios dominantes se tornam "livres de não pensar" (ADORNO; HORKHEIMER, 2006). A autonomia é destituída de seu próprio direito para, assim, garantir a então frágil existência de pessoas não-emancipadas, enquanto categorias sociais, falsos indivíduos.

Isso tudo de modo tão perspicaz e faceiro, dominador e bárbaro, que "sob o monopólio privado da cultura a tirania deixa o corpo livre e vai direto à alma" (ADORNO; HORKHEIMER, 2006, p.110), com exceção que nas bordas sociais os corpos continuam impedidos, esgarçados e rasgados, com sangue retinto, pisado e esquecido pelas páginas dos grandes jornais. E tal como é introduzida no prefácio do livro Educação e Emancipação, de Adorno (2006), "a indústria cultural obscurece por razões objetivas, aparecendo como uma função pública da apropriação privada do trabalho social. Na continuidade de seu próprio desenvolvimento, o esclarecimento se inverte em obscurantismo e ocultamento" (MAAR, 2006, p.21, 22).

A ideia de indivíduo que se forma e se constitui em si mesmo, fechado em sua "substância particular", evidencia essa irracionalidade objetiva e a sua perversidade, impede a consciência, o reconhecimento e a compreensão de que a formação subjetiva, bem como qualquer práxis humana, é também a expressão das relações socioculturais de seu tempo. Como consequência, de acordo com Adorno (2004, p.50), "La separación de los actos sociales en los que se reproduce la vida de los hombres, y ellos mismos, les impide llegar a ver el mecanismo, y los deja a merced de esa sentencia según la cual todo se reduciría al ser humano mismo [...]”. Em consequência, a irracionalidade continua a se expressar em seu perjúrio social para com a história e para com a memória dos desvalidos, gozando de uma consciência alienada, a qual tudo permite pela mítica promessa da ordem, do progresso e do bem-sucesso: 
Existe um povo que a bandeira empresta

P'ra cobrir tanta infâmia e cobardia!...

E deixa-a transformar-se nessa festa

Em manto impuro de bacante fria!...

(ALVES, 2008, p.28).

De acordo com a proposta teórico-conceitual de Honneth $(2003,2013)$ para construção de uma coletividade ética para a democracia, as perspectivas unilaterais comprometem a qualidade do seu processo de socialização, e, por conseguinte, o efetivo desenvolvimento do reconhecimento recíproco e do direito, em que, "[...] reconhecer-se reciprocamente como pessoa de direito significa que ambos os sujeitos incluem em sua própria ação, com efeito de controle, a vontade comunitária incorporada nas normas intersubjetivamente reconhecidas de uma sociedade" (HONNETH, 2003, p.138). Na verdade, a construção de uma coletividade ética só será possível mediante a sua emancipação frente ao estado bárbaro e seus correlatos. Aquilo que Honneth define por reconhecimento recíproco não coexiste dentro de uma sociedade atomizada, é ideológico: a igualdade é incondizente com a racionalidade e estrutura social da dominação (ADORNO, 2004). Para o seu real desenvolvimento, é preciso antes a consciência quanto aos fenômenos sociais e psicológicos envolvidos com a produção de perspectivas unilaterais. Em outras palavras, "a emancipação da sociedade relativamente ao antissemitismo depende da possibilidade de elevar ao conceito o conteúdo da idiossincrasia e de tomar consciência de seu absurdo" (ADORNO; HORKHEIMER, 2006, p.148)

À vista disso, e à luz do contexto e da realidade do território dos distritos de Pedreira e da Cidade Ademar - principalmente, ao que toca o âmbito de políticas públicas dessa região e, consoante a isso, às vulnerabilidades e às desigualdades sociais constatadas -, pudemos verificar a expressão da inexistência do reconhecimento mútuo e, consequentemente, o frágil entendimento quanto à noção de pessoa de direito, em especial, ao que diz respeito à esfera do reconhecimento jurídico (HONNETH, 2003). Tendo-se que este último, enquanto respeito universal, “[...] expressa que todo ser humano deve ser considerado, sem distinção, um 'fim em si" (IHERING apud HONNETH, 2003, p.184), ou seja, em sua humanidade, ao passo que, na realidade da sociedade vigente, as demandas e os interesses comunitários das periferias da zona sul não estão sendo, de fato, incorporados nas agendas e pautas do governo, muito menos parecem estar contemplados nas "normas intersubjetivamente reconhecidas", seja no âmbito jurídico ou no âmbito da cidadania. 
A confrontação entre a ausência de equipamentos públicos culturais nos distritos de Pedreira e da Cidade Ademar, por exemplo, e a concentração de investimentos públicos em cultura nas regiões "nobres" de São Paulo, evidencia um tipo de atuação do Estado, cujo respeito continua historicamente a responder aos interesses privados, subscritos em seu autovalor, a estima social (HONNETH, 2003), a qual “[...] salienta o 'valor' de um indivíduo, na medida em que este se mede intersubjetivamente pelos critérios da relevância social" (IHERING apud HONNETH, 20003, p.184). Ou seja, o desenvolvimento efetivo do reconhecimento recíproco encontra-se comprometido na sociedade contemporânea, de maneira geral, visto que a lógica do respeito social continua a ter cor, gênero, endereço e classe social. Isso leva, pois, aqueles que vivem nas periferias a uma situação de não apenas lá residirem, mas sim, de terem que resistir a isso por motivo de sobrevivência (GOG apud TOMMASI, 2013). Diante do quadro de indicadores de vulnerabilidade e desigualdade social verificados nos distritos de Pedreira e da Cidade Ademar, é possível presumir que o modo como as relações jurídicas se constituem dentro do nosso contexto social, o de que as propriedades universais do ser humano, "que faz dele uma pessoa" (HONNETH, 2003, p.187), ficam à revelia das propriedades particulares "que o caracterizam, diferentemente de outras pessoas" (HONNETH, 2003, p.187). Por conseguinte, na ausência da crítica à dominação social e ao tipo de conceito de esclarecimento por ela adotado, contribui-se para a formação de uma compreensão de igualdade social apenas aparente, ou melhor dizendo, onde o universal se impõe diante do indivíduo, massificando-o. Conforme a crítica de Adorno e Horkheimer:

A dominação defronta o indivíduo como o universal, como a razão na realidade efetiva. O poder de todos os membros da sociedade, que enquanto tais não têm outra saída, acaba sempre pela divisão do trabalho a eles imposta, por se agregar no sentido justamente da realização do todo, cuja racionalidade é assim mais uma vez multiplicada. Aquilo que acontece a todos por obra e graça de poucos realiza-se sempre como a subjugação dos indivíduos por muitos: a opressão da sociedade tem sempre o caráter da opressão por uma coletividade. É essa unidade de coletividade e dominação e não universalidade social imediata, a solidariedade que se sedimenta nas formas do pensamento. (ADORNO; HORKHEIMER, 2006, p. 30, 31)

\subsection{Estéticas marginais, resiliência e luta por reconhecimento: uma voz que ecoa}

Tentaram me calar, 
mas foi em vão...

minha voz se fez ouvir

lá no porão...

(Luana Bayô - Voz negra)

Mediante as facetas da exclusão social, essa realidade de adversidade pode não só gerar um possível conformismo a uma vida desrespeitada, de olhos ofuscados, como resposta à sua impotência; pode também incitar a subordinação voluntária ao ajustamento custoso da própria vida, buscando responder, por meio do trabalho, do consumo e da própria alma, às demandas dos mecanismos sociais de controle para que, deste modo, ilusoriamente, corresponda à estima social, deixando-se levar pelo desejo introjetado do sucesso, de que, quem sabe um dia, como os protagonistas das novelas, sejam eles também bem-sucedidos pelo acaso da sorte (ADORNO; HORKHEIMER, 2006); pode haver ainda aqueles que se entorpecem diante da Quimera em uma "embriaguez narcótica, que expia com um sono parecido à morte a euforia na qual o eu está suspenso [...]" (ADORNO; HORKHEIMER, 2006, p.39). E outros que, com ego ainda tão mais frágil, rasgam-se por dentro, implodem e gritam a loucura da barbárie em seus próprios rangeres de dente. Em todas essas dimensões determinadas e conectadas pelos mesmos determinantes sociais, por conseguinte, ocorrem a dominação dos sentidos, o empobrecimento da experiência sensível e o abandono do pensamento. Enquanto são dominados pela grande maquinaria do poder econômico e, assim sendo, pela racionalidade do mundo administrado, assim como os navegantes companheiros de Ulisses, com seus ouvidos cobertos por cera e com seus braços incessantes a remar, buscam a autoconservação às custas da própria vida sensível, da renúncia de seus sonhos e da sua autonomia, uma vez que:

Quem quiser vencer a provação não deve dar ouvidos ao chamado sedutor do irrecuperável e só alcançará se conseguir não ouvi-lo. Disso a civilização sempre cuidou. Alertas e concentrados, os trabalhadores têm de olhar para frente e esquecer o que foi posto de lado. A tendência que impele à distração, eles têm de se encarniçar em sublimá-la num esforço suplementar. É assim que se tornam práticos (ADORNO; HORKHEIMER, 2006, p.39).

Ou, então, como os lotófagos, amaldiçoados pelo sofrimento inescapável quanto à opressão e hostilidade social, há aqueles que se entregam ao esquecimento de si nas frestas de uma felicidade aparente pela "psicodelia" dos seus vícios "[...] a fim de suportar o insuportável” (ADORNO; HORKHEIMER, 2006, p.59), sendo, então, duplamente excluídos pela razão auto 
conservadora que exige a renúncia voluntária da consciência do prazer. Todavia, há aqueles que mesmo curvados pelo peso da barbárie, não se deixam estar de acordo por completo, não se entregam totalmente à lábia do negociante de diversões, à submissão voluntária ou mesmo à reificação da consciência alienada. Nessa dimensão, por assim dizer, podemos reconhecer essa postura de enfrentamento político social como objetivo cerne da práxis dos projetos sociais, os quais parecem se agarrar a uma "[...] última idéia de resistência" (ADORNO; HORKHEIMER, 2006, p.119), não deixando-se desistir da possibilidade de uma subjetividade pulsante e da possibilidade da autonomia do pensamento, tendo na arte e na cultura a possibilidade política do reencontro entres esses dois domínios: aproximando-se pois da ideia de arte engajada (ADORNO, 1993), a arte enquanto uma função social.

As organizações sociais, de um modo geral, rebelam-se contra a dominação social e contra os mecanismos e artifícios da indústria cultural e que, por mais que essa rebelião seja "o resultado lógico do desamparo para o qual ela própria o educou" (ADORNO; HORKHEIMER, 2006, p.119), e mesmo havendo uma possível reprodução de mecanismos de ajustamento dentro dessas formas de organizações grupais, não se pode afirmar categoricamente a imobilidade total das massas em relação à "lei do grande número" (ADORNO; HORKHEIMER, 2006, p.120).

A luta por reconhecimento e as práticas socioeducativas que envolvem o ensino de diferentes modalidades artísticas em projetos sociais são prova de uma tentativa ativa de enfrentamento e de crítica social. Os objetivos que norteiam os projetos sociais e suas mais diversas variantes, comunitários ou instalados nos principais bolsões de pobreza (em determinadas zonas rurais e nas periferias das cidades grandes) se caracterizam sobretudo pelo seu caráter sociopolítico cultural e educacional, visando-se à transformação social, ao desenvolvimento da cidadania e à formação do indivíduo, as quais, dentro do contexto de tais organizações, e em tese, estão intimamente relacionadas com os repertórios populares e comunitários, bem como com as suas causas sociais (GOHN, 2015).

Por meio das diferentes modalidades estéticas, da arte, da cultura e, por sua vez, de práticas educativas e formativas, as diferentes formas de organizações socioculturais tendem a articular em suas práticas os conteúdos da história e da memória local, regional, dos personagens comuns, anônimos à história formal e lacunar. Tratando-se de um resgate da memória em resposta-resistência à destruição da própria memória e, consequentemente, “[...] do desaparecimento da consciência da continuidade histórica" (ADORNO, 2006, p.32). Síntese do 
processo estrutural da pseudoformação e da semicultura como resultado operante da razão dominante e, consequentemente, do empobrecimento da experiência e do enfraquecimento social do indivíduo pelos mecanismos da indústria cultural. Contra estas forças, o resgate da memória histórica e da cultura popular se põe a frente em muitos dos projetos socioculturais educativos de modo a se fazer uma luta por reconhecimento (HONNETH, 2003) para que, por meio de práticas e intervenções de cunho formativo, se contribua para a formação de grupos e de indivíduos mais fortalecidos subjetivamente diante das forças hostis, coercitivas e opressoras do condicionamento e da adaptabilidade social, para que, assim, seja possível a transformação social no sentido de se construir uma eticidade coletiva para a concretude da democracia em seu sentido conceitual pleno e profundo: o da real possibilidade de existência e coexistência entre os processos de socialização e individuação; o reconhecimento mútuo; a humanização da consciência, a consciência sensível; a justiça social; a existência da concretude de uma relação possível entre razão e liberdade. Assim seja, por um princípio de realidade por meio do qual seja possível a emancipação do sujeito. No caso em questão do projeto participante da pesquisa empírica, mais especificamente, a educação, a arte e a cultura e, mais especificamente, a música e a educação musical, aparecem estreitamente vinculadas aos princípios básicos dos direitos humanos, da democracia e da formação de uma consciência sensível, bem como dos seus valores correlatos (respeito, coletividade, solidariedade, comprometimento, etc.) e objetivos estabelecidos (garantia de direitos básicos, educação de qualidade, formação de senso crítico e desenvolvimento de cidadania, por exemplo) de modo que, conforme a coordenadora pedagógica, seja possível "se emocionar, de a gente ter um caminho de fato que a gente possa se fazer presente mesmo, se fazer consciente" e que "[...] os alunos consigam se pontuar, se enxergar no mundo, de que eles possam ser autônomos de si e, principalmente, propagadores do que eles aprenderam aqui dentro...já têm alunos, inclusive, que atuam nos grêmios da escola, levando atividade musical, planejando atividades culturais [...]" (A., coordenadora pedagógica, entrevista 1, Anexo D).

Pelo tipo de propostas apresentadas, de modo geral, pelas organizações sociais, pelos seus objetivos, princípios e valores, essas reagem à passividade da alienação social, não se entregam ligeiras à moral e às recompensas inalcançáveis, prometidas em troca da própria alma, mas buscam responder à exclusão social não desmoronando-se ou conformando-se a essa, mas esforçam-se para resguardar a própria vitalidade sobrevivente, um puxadinho de alegria de viver e a possibilidade mínima de consciência crítica: pela solidariedade, pelo acolhimento, pela 
enfrentamento coletivo, pelo resgate e pela valorização da sua história e memória - de seus heróis anônimos, de sua herança cultural e ancestral -, pela valorização das suas próprias narrativas, pelo desenvolvimento de suas capacidades cognitivas e sensíveis, pelo lirismo popular, etc.

O modo de enfrentamento das adversidades sociais pelas diversas organizações sociais seja pela instância jurídica, pela garantia de determinados direitos, seja pela reconstrução da opinião pública, pelo resgate da memória ou pelo sentimento de pertencimento comunitário e pelo fortalecimento da autoestima -, leva-nos a reconhecer uma práxis estética, educativa e cultural marcada pela diretiva da resiliência enquanto proposta coletiva e/ou institucional de superação e de transformação de experiências negativas da comunidade local (PERES et al., 2018). Essa práxis é comum e característica dos projetos sociais, organizados com o intuito de ser soluções para problemáticas comuns da comunidade (GOHN, 2009, 2015), destacando-se, nesse sentido, a relação dos moradores e de idealizadores de projetos filantrópicos com a arte, cultura e esporte, enquanto “[...] diferentes estratégias de lidar com as adversidades cotidianas" (BEZERRA, 2009; TAKEUTI, 2010 apud PERES et al., 2018, p.62). Em contextos como os das periferias, a compreensão acerca da resiliência dialoga com aquilo que se entende, a partir de Honneth (2003, 2013), como luta por reconhecimento, visto que em ambos os trabalhos conceituais, evidenciaram-se, em seus conteúdos, as forças existentes de enfrentamento da população local e as de todos aqueles envolvidos e solidários às suas causas de luta contra as diferentes dimensões da dominação social. A resiliência é compreendida por alguns autores contemporâneos, a partir da adoção de concepções essencialistas, referindo-se:

[...] às condições de sujeitos ou coletivos que superam os efeitos das adversidades às quais são submetidos, podendo sair fortalecidos e transformados dessas experiências (Cabral \& Cyrulnik, 2015; Ferreira, Silveira \& Peixoto, 2013). Enquanto as periferias urbanas são muitas vezes naturalizadas em suas adversidades e determinadas pela forma como se conta sua história, a noção de resiliência desafia a inércia com a qual elas costumam ser compreendidas (Ferreira et al., 2013). Pelo olhar da resiliência, é possível focalizar as vivências de enfrentamento às incongruências dos espaços marginalizados urbanos (Bezerra, 2015; Takeuti, 2010) (PERES et al., 2018, p.62).

[...] algumas concepções essencialistas do termo, no presente estudo entende-se à resiliência como um processo, o qual inclui ser afetado por adversidades, enfrentando-as e transformando-as em potencialidades de crescimento (Cabral, 2012, 2015; Cyrulnik, 2001/2004, 2016; Ferreira et al, 2013). A resiliência representa não uma tentativa de apagar o que acontece ou aconteceu, mas uma 
busca por caminhos que podem ser abertos a partir do que se vive (Bezerra, 2009, 2015; Cabral, 2015; Cyrulnik, 2016, 2015) (PERES et al., 2018, p.62).

Frente a este contexto territorial periférico e, mais especificamente, aos movimentos e coletivos culturais e artísticos ali atuantes, a luta por reconhecimento está para o processo de resiliência como o próprio campo para possíveis experiências de enfrentamento e transformação (individual e social). Para crianças e adolescentes desta comunidade, em pleno desenvolvimento, essa luta pode corroborar para a qualidade do seu próprio processo de socialização e da sua possível autodeterminação no que se refere, por exemplo, ao desenvolvimento do auto-respeito e da sua autoestima - viabilizados por meio da vivência e/ou experiências grupais de relacionamento, de respeito, de solidariedade, de apoio, de reconhecimento, de motivação, de garantia de direitos, etc. - em detrimento da continuidade de relações interpessoais monadológicas, das perspectivas unilaterais negativas e da ideia decorrente do fracasso, do contentamento e do conformismo diante da situação de desigualdade social.

Mesmo que a indústria cultural já tenha transformado a imagem de Dandara dos Palmares e da negra escrava Anastácia em valor agregado, a força representativa de rebeldia, resistência e de luta ainda não se ausentou dessas personagens da história brasileira, justamente pela preservação de suas histórias nesses terreiros comunitários por meio das diferentes narrativas artísticas e produções culturais. Diferentemente do entretenimento, os coletivos e os movimentos culturais, por exemplo, buscam convoca do espectador um envolvimento e um esforço intelectual para o reconhecimento e para a compreensão quanto a uma verdade a ser denunciada ou reapresentada, que, semelhante ao engagement, a relação estabelecida com a arte, enquanto função social, caracteriza-se por uma determinação estética com intento para a reflexão e para a crítica, "[...] mediatizada relativamente à realidade enquanto sua negação determinada" (ADORNO, 2011, p.123). Ou seja, pelos seus conteúdos de uma história não legitimada socialmente em confronto com a totalidade da história única, tais forças artísticas de enfrentamento não se entregam passivas à indústria da diversão ligeira, ou mesmo da distração por vezes forçosa; inspiram, desta forma, a continuidade da história da luta, dessa vez, por meio da arte, da cultura e da educação, por mais que seja reprimida ou censurada nos livros das escolas brasileiras, como o é a história de tantos outros combatentes além de Dandara e Anastácia: mulheres negras escravas e quilombolas, intelectuais negros, índios tupiniquins e tupinambás (como de outras tantas etnias), mulheres da vida, boêmios da noite, poetisas, "flores do mal". 
Essa força social pelos diferentes movimentos artísticos e da cultura popular fícou evidenciada, por exemplo, no ano de 2019 durante uma das principais manifestações culturais brasileiras, o carnaval, no qual em sua expressão festiva popular, pôde-se sobressaltar-se pelo arrojo de sua intenção para uma crítica social quanto ao desconhecimento programado da história frutacor brasileira através, especialmente, da escola de samba Estação Primeira de Mangueira que, ao recontar a história do Brasil em seu samba-enredo e em seu desfile por meio do resgate de outros heróis da gente esquecida, das veias abertas pela colonização, confrontou a história única, a dos dominantes:

Comemoramos 500 anos de Brasil sem refazermos as contas que apontam para os mais de 11.000 anos de ocupação amazônica, para os mais de 8.000 anos da cerâmica mais antiga do continente, ou ainda, sem olhar para a civilização marajoara datada do início da era Cristã. Somos brasileiros há cerca de 12.000 anos, mas insistimos em ter pouco mais de 500, crendo que o índio, derrotado em suas guerras, é o sinônimo de um país atrasado, refletindo o descaso com que é tratada a história e as questões indígenas do Brasil. Não fizeram de Cunhambembe - a liderança tupinambá responsável pela organização da resistência dos Tamoios - um monumento de bronze. Os índios Cariris que se organizaram em uma confederação foram chamados de bárbaros. Os nomes dos caboclos que lutaram no Dois de Julho foram esquecidos. Os Índios, no Brasil da narrativa histórica que é transmitida ainda hoje, deixaram como "legado" cinco ou seis lendas, a mandioca, o balanço da rede, o tal do "caju", do "tatu" e a "peteca". [...] O fato é que a atuação de "gente comum", ou mesmo a incansável luta negra organizada em quilombos, em fugas, no esforço pessoal ou coletivo na compra de alforrias e em revoltas ou conspirações, já enfraqueciam o sistema escravocrata àquela altura. Entretanto, ensinar na escola o nome de "Chico da Matilde, jangadeiro, mulato pobre do Ceará (líder da greve que colocou fim ao embarque de escravos no estado nordestino, levando-o à abolição da escravatura quatro anos antes da princesa ganhar sua "fama" abolicionista) não serviria à manutenção da premissa de que as conquistas sociais resultam de concessões vindas "do alto" e não das lutas. A história de Chico da Matilde era inspiradora demais para o povo. Não à toa, seu nome não está nos livros (GRES ESTAÇÃO PRIMEIRA DE MANGUEIRA, 2019).

As forças populares e comunitárias, contíguas e herdeiras da história de luta da "gente comum”, fazem frente ao monopólio cultural, recontando a sua própria história através da cultura popular de modo a se resgatar a esperança e a coragem da história diante da fraqueza social do eu, da estrutura da personalidade autoritária, e, desta forma, da própria ideologia dominante (ADORNO, 2006), por mais que possuam suas limitações em relação à arte autônoma, por mais que haja pouco discernimento consciente quanto às dimensões estéticas envolvidas (a estética 
como produção cultural que aparenta a dimensão estética como reflexão crítica), e por mais que sejam ínfimas diante da perspicácia da indústria cultural e por ela sejam também cooptadas, ou até estejam fadadas ao fracasso diante à perversidade do sistema. Não se dobram à ideia de um mero espetáculo cômico como eternos consumidores, onde "a diversão favorece a resignação, que nela quer se esquecer" (ADORNO; HORKHEIMER, 2006, p.117); na verdade, muitas das intervenções dos movimentos e dos coletivos culturais não buscam produzir humor, mas sim provocar o desconcerto do automatismo, o envolvimento dos olhos antes distraídos pelo riso falso - o Teatro do oprimido, método criado pelo dramaturgo, diretor e teórico Augusto Boal, é um importante exemplo disso, o da desmecanização do corpo servil por meio de uma construção conjunta (atores e espectadores) de uma crítica sensível acerca da dominação social e de uma reconstrução da estética do oprimido.

O sofrimento denunciado desde os primeiros navios negreiros - e antes deles, o genocídio indígena -, e nas estatísticas atuais, nesses grupos, não coadunam com a intenção objetiva da moral da estética burguesa do trágico, o qual, como descrevem Adorno e Horkheimer (2006, p.125), “[...] é reduzido à ameaça da destruição de quem não coopera [...]”, mas sim expõe elementos de tal contingência ideológica, aproximando-se, por seu turno, do sentido paradoxal do trágico, fornecido pela arte, que, segundo esses mesmos autores, “[...] consistia outrora resistência desesperada à ameaça mítica" (ADORNO; HORKHEIMER, 2006, p.125). Não deixam, pois, de se opor à barbárie social, ao mesmo tempo que, porém, “[...] ao assemelhar-se às coisas reais, se adapta no entanto à reificação, contra a qual protesta" (ADORNO, 1993, p.123).

\subsection{O funk e o rap como repertórios estéticos musicais da juventude periférica: entre estéticas musicais afirmativas e a indústria cultural}

O rap e o funk são estilos musicais diretamente vinculados à cultura local das periferias enquanto forças simbólicas identitárias e reagentes estéticas do estado de exclusão social, ao mesmo tempo que também atravessaram os limites geográficos, sociais e simbólicos e atingiram outras áreas urbanas e estratos sociais (DAYRELL, 2002; TROTTA, 2016). Por outro lado, são socialmente desqualificados a um teor de ilegitimidade estética perante às concepções classicistas de arte superior (TAKEUTI, 2010) ou do que vem a ser valorizado conforme seu status e valor comercial enquanto bem cultural petrificado (ADORNO, 2005). Esses estilos musicais são objetos de percepções depreciativas, não somente em decorrência de um possível entendimento 
crítico musical quanto à sua consistência estética, mas também como extensão e desdobramentos de perspectivas estereotipadas projetadas sobre as periferias. Dados relativamente evidenciados também nas falas dos entrevistados desta pesquisa, mais propriamente em relação ao funk, cujo gosto musical foi caracterizado pela maioria dos entrevistados como sendo algo "simples", "limitado", "vulgar", "pesado":

No nosso caso, aqui, que a gente está dentro do contexto da periferia, isso (educação musical), para as crianças e para os adolescentes, tem uma importância, a gente percebe que tem uma importância muito grande, porque o contexto musical deles é um tanto limitado [...] (A., coordenadora pedagógica, entrevista 1, Anexo D).

A gente não leva, assim, eles pra ver show de funk, por exemplo. Eu não queria falar, mas tem que falar, né. Que é uma coisa que a gente não consegue aceitar. E é uma coisa que está muito forte, parece até que não tem como fugir. Não é uma música boa para se aprender (B, professor de música, entrevista 2, Anexo D).

[...] o tipo de música consumida aqui nessa comunidade e em tantas periferias é o funk, o forró ou outras formas de música mais simples, mas, é, ainda que sim, está bom ou não está bom, é o vulgar. Quem nunca viveu o que acontece na periferia, nesses funks. Então, acaba sendo muito limitado esse universo que é apresentado à criança e ao jovem, né. É o acesso que eles têm. Então, eles acabam nem tendo a possibilidade, a oportunidade, de conhecer outras propostas (C., presidente, entrevista 3, Anexo D).

O que dá indícios de elementos psicossociais inerentes ao preconceito, à desigualdade e à exclusão social que se expressa também nas instâncias da desconsideração e ausência de compreensão quanto ao percurso histórico e social dessas pessoas, bem como, em decorrência, do tipo de formação cultural resultante. Ao mesmo tempo em que isso também revela dados relativos à semicultura e à fragilidade de aptidão à experiência por essa população.

O rap e o funk, para além da opinião comum negativa, são produções musicais que se configuram como referências culturais locais dos jovens das periferias (DAYRELL, 2002; TAKEUTI, 2010), que dentro do contexto social excludente, tornam-se um espaço possível para o protagonismo juvenil, para a coletividade, e, na perspectiva de alguns autores contemporâneos, para a construção identitária dos jovens (DAYRELL, 2002; TROTTA, 2016). Desprovidos de recursos objetivos e sociais suficientes para a experiência estética e para a formação cultural por meio de políticas de educação e de uma educação política, o rap e o funk, cada um ao seu modo, 
delineiam um espaço possível de encontro, convivência, reconhecimento, identificação, solidariedade, bem como de valorização comunitária, pertencimento, ressignificação e reelaboração de experiências negativas. O que remete à ideia de resiliência, já que, segundo Juarez Dayrell (2002):

[...] o rap é um meio de que se servem para articular uma auto-imagem positiva, uma forma de se afirmarem como "alguém" numa sociedade que massifica e os transforma em anônimos. Ao mesmo tempo, através das letras das músicas, do corpo e do visual que valorizam a estética negra, na afirmação positiva do espaço da periferia, o rap possibilita a muitos desses jovens reelaborar a experiência social imediata em termos culturais, traduzida em forma de autoconsciência diante do processo de segregação espacial e dos preconceitos sociais e raciais [...] Também o funk possibilitou a esses jovens a ampliação da rede de relações. Por meio dos bailes e shows, estabeleceram uma rede de relações amplas - os conhecidos - que não possui uma estrutura de coesão tão forte entre aqueles que dela participam: reconhecem-se no funk, compartilham situações lúdicas, encontram-se nos bailes, sentindo-se parte de uma rede simbólica (DAYRELL, 2002, p.128-132).

À luz dos conceitos de reconhecimento, luta por reconhecimento e direito (HONNETH, 2003, 2013), o rap e o funk não se inserem formalmente como produções musicais resultantes de formações grupais articuladas politicamente e que visem ao confronto direto da realidade de desrespeito à população periférica, o que é próprio das organizações sociais; por outro lado, muitas das intervenções culturais que envolvem essas modalidades musicais dentro deste contexto apresentam a "[...] intenção de inventividades na busca de "vias de saída" para a sua limitada condição de vida de jovens de "periferia'” (TAKEUTI, 2010, p.14).

Esses estilos musicais surgem dentro de um contexto de enfrentamento político e social: originaram-se a partir da música negra americana com fortes influências da sonoridade africana (em especial, o ritmo e as tradições musicais orais) e do soul, característico da década de 1960, momento marcado por uma série de movimentos sociais e pela juventude revolucionária, sendo este gênero musical símbolo da consciência negra daquela época (DAYRELL, 2002). Entretanto, nenhuma dessas influências musicais, bem como o rap e o funk, ficaram imunes aos mecanismos de massificação da cultura, ao imediatismo do consumo e à regência do processo de (pseudo)formação de uma escuta de entretenimento, visto que nem a música escapa às leis do mercado (ADORNO, 2011) e o gosto musical se reduz ao prato de todos os dias (ADORNO, 1975; ADORNO; HORKHEIMER, 2006), o qual já não mais consiste em uma escolha 
verdadeiramente livre a partir da fruição estética reflexiva da música, passando a ser uma falso julgamento e uma falsa escolha, cujo critério replica a estrutura que subjaz "[...] o fato de a canção de sucesso ser conhecida de todos; gostar de um disco de sucesso é quase exatamente o mesmo que reconhecê-lo. O comportamento valorativo tornou-se uma ficção para quem se vê cercado de mercadorias musicais padronizadas"(ADORNO, 1975, p.173).

Apesar de se oporem à exclusão social das camadas urbanas mais pobres, seja pela socialização ou pela crítica social, esses estilos musicais já são resultados da decadência da consciência autônoma e, consequentemente, do empobrecimento dos materiais estéticos enquanto produtos da indústria cultural, já que "O mundo inteiro é forçado a passar pelo filtro da indústria cultural” (ADORNO; HORKHEIMER, 2006, p.104). Segundo Adorno e Horkheimer:

[...] os elementos sensíveis - que registram sem protestos, todos eles, a superfície da realidade social - são em princípio produzidos pelo mesmo processo técnico e exprimem sua unidade como seu verdadeiro conteúdo. Esse processo de elaboração integra todos os elementos da produção, desde a concepção do romance (que já tinha um olho voltado para o cinema) até o último efeito sonoro (ADORNO; HORKHEIMER, 2006, p.102).

De todo modo, tanto o rap como o funk apresentam-se como reação informal frente à realidade de ausência de políticas culturais que contemplem essa população e o seu repertório cultural, e, em consonância, os seus direitos não garantidos pelo Estado, em especial, a juventude: “[...] pelos estilos rap e funk, os jovens estão reivindicando o direito à juventude" (DAYRELL, 2002, p.134). Um respiro de existência afirmada e experimentada e uma possibilidade de sociabilidade e pertencimento grupal. Ao mesmo tempo que essa dinâmica ainda esteja longe de se alcançar as condições fundamentais para a experiência estética musical, para uma escuta pensante e como expressão de um efetivo processo de individuação autônoma, quando, na verdade, limita-se à produção de bens culturais e a novas formações grupais com pessoas excluídas pelo macrocosmo social, reproduzindo a estrutura psicodinâmica desta ao manter enfatizada a ordem do todo, do coletivo, sobre a possibilidade do singular pela individuação (ADORNO; HORKHEIMER, 2006).

Porém, mesmo diante de uma sociedade a qual pouco contribui para a formação de bons ouvintes - no sentido do tipo de escuta proposto por Adorno (2011), o de um estabelecimento de relações espontâneas criativas com a música, de forma a se produzir juízos fundamentados ao 
invés de uma mera valorização heterônoma arbitrária e que se valha de condicionamentos da adaptabilidade social forçosa (da estima e do prestígio, por exemplo) -, não podemos deixar de reconhecer a conduta inventiva dessas pessoas mesmo diante das condições sociais escassas para a sua emancipação, tratando-se, pois, de um passo para a tentativa de tensionamento contra o todo social em detrimento do conformismo imediato às forças homogeneizantes da normatização e ajustamento social. O qual não deve ser ignorado no campo do planejamento das políticas culturais e educativas (ADORNO, 2006), pois refere-se a conteúdos sociais e psicológicos próprios das comunidades periféricas dos grandes centros urbanos. $\mathrm{O}$ que permite pensar sobre a realidade social na qual se pretende organizar um projeto educacional para melhor estruturá-lo, no sentido de uma práxis formativa consciente e objetiva, tendo-se em vista que "A importância da educação em relação à realidade muda historicamente" (ADORNO, 2006, p.144).

O rap é oriundo da cultura musical black, que, conjuntamente com o grafite, o break e a discotecagem, compõem a base da cultura hip hop, “[...] fazendo da rua o espaço privilegiado da expressão cultural dos jovens pobres" (DAYRELL, 2002, p.125). Esse estilo musical mistura, num jogo de mixagens, a tradição ancestral africana com a moderna tecnologia, caracterizando-se também pelo seu teor de crítica social, “[...] produzindo um discurso de denúncia da injustiça e da opressão a partir do seu enraizamento nos guetos negros urbanos” (DAYRELL, 2002, p.125), como também se propõe "a novas maneiras de pensar, fazer e viver na própria 'periferia" (TAKEUTI, 2010, p.16). O rap, como o hip hop de maneira geral, se tornou um estilo musical comprometido como a arte engajada que, na sua própria linguagem no contexto brasileiro, buscase uma "atitude consciente" (TAKEUTI, 2010). Pode-se inferir que a relação que se intenta estabelecer com o rap é a de uma experiência musical de escuta pensante (ADORNO, 2011), por meio de seus produtores e ouvintes, não se rendendo necessariamente a uma relação imediata de consumo cultural, ao que parece; ao mesmo tempo que, contraditoriamente, assim o faz, cuja estrutura criativa e de escuta são pré-determinadas e padronizados, e cujos conteúdos de verdade, assim como na arte engajada, são evidenciados de imediato, comprometendo a espontaneidade criativa, a experiência e o pensamento (ADORNO, 1993). Tal como é evidenciado por Dayrell:

Nessa produção poética, a estrutura das letras, a fidelidade ao território e a explicitação de uma temática social são elementos identificadores do rap em qualquer lugar, seja no Brasil ou nos Estados Unidos. Ao mesmo tempo, o conteúdo poético tende a refletir o lugar social concreto onde cada jovem se situa e a forma como elabora suas vivências, numa postura de denúncia das 
condições em que vive: a violência, as drogas, o crime, a falta de perspectivas, quando sobreviver é o fio da navalha. Mas também cantam a amizade, o espaço onde moram, o desejo de um "mundo perfeito", a paz (DAYRELL, 2002, p.127, 128).

Por meio da cultura hip hop, os jovens das periferias passam a ter vez, voz e espaço para a expressão e representatividade de suas realidades sociais, além de proporcionar espaços de vivências para se repensar a própria vida. De acordo com Takeuti:

[...] nela a arte e a vida se conectam (as letras do rap e os temas gestuais e visuais falam sobremaneira da vida na adversidade e da resistência das minorias sociais). A realidade social vivida, os interesses da vida cotidiana e os desejos reprimidos vão sendo falados/cantados/dançados/desenhados num ritmo e som que os estimulam a repensar a sua existência social. Arte e experiência vão sendo resgatadas simultaneamente no viver cotidiano desses jovens (TAKEUTI, 2010, p.18).

Apesar do rap e a cultura hip hop como um todo promoverem uma estética por meio da qual se viabiliza a denúncia e se busca promover a reflexão e a crítica social, cabe questionar quanto à sua qualidade estética, as condições tanto para a possibilidade de experiência estética musical, quanto para uma escuta pensante e problematizá-las: se estão de fato a conseguir provocar a consciência de seus ouvintes, produzir pensamento ou, de modo contrário, a se introjetar um já posto e a converter tal intento de um estética reflexiva crítica a um estado de bem cultural popular (ADORNO, 1975). Para isso, cabe pensar sobre a qualidade de suas próprias propriedades estruturais e objetivas da música na relação com seu contexto e momento social (ADORNO, 2011). Caso contrário, esse estilo musical, como tantos outros, vem a estar entregue às leis da indústria cultural sem que suas leis específicas possam de fato ter condições para se expressar esteticamente em um mínimo balanço de forças.

Como se pôde observar, a partir de uma análise sucinta, o rap consiste em uma produção musical, assim como o funk, que apresenta uma tendência estilística muito marcada, que se sobrepõe à relação daquilo que viria a ser as leis específicas da arte (ADORNO, 2011). O mesmo que dizer que o seu estilo musical, as formas dominantes da universalidade da estrutura musical, se sobrepõe à possibilidade de autonomia da arte e de sua autenticidade estética. Elementos constitutivos da padronização, própria da música popular, a estandardização (ADORNO, 1986), e própria da sociedade administrada pela indústria cultural que produz a consciência das massas 
(ADORNO; HORKHEIMER, 2006). Apesar da diversidade de letras e músicas, essas se assemelham perceptivelmente umas às outras em sua sonoridade, como sucedâneo da identidade (ADORNO; HORKHEIMER, 2006). O que corresponde à compreensão de Adorno e Horkheimer quanto à significativa interferência e determinação da indústria cultural sobre o campo da arte e da cultura, para estes autores:

A indústria cultural acaba por colocar a imitação como algo de absoluto. Reduzida ao estilo, ela trai seu segredo, a obediência à hierarquia social. A barbárie estética consuma hoje a ameaça que sempre pairou sobre as criações do espírito desde que foram reunidas e neutralizadas a título da cultura (ADORNO; HORKHEIMER, 2006, p.108).

O que indica a sua discrepância com a arte autônoma, que concilia suas leis específicas com as leis gerais de um estilo, das determinações sociais de uma época, de modo a também se opor a estas na relação (ADORNO, 1993).

Embora haja conteúdos críticos pertinentes em sua estética dura e denunciativa, semelhante à relação do expert de jazz, tal como é definido na categorização elaborada por Adorno (2011), esses conteúdos de crítica social e suas formas estéticas são previstas, com o predomínio marcado do "tempo" a que todas as artes sincopadas devem obedecer. Apesar de não se tratar diretamente de uma escuta passiva e descompromissada, pois visa à reflexão do ouvinte, acaba por ser uma escuta fácil e também de entretenimento (a crítica está dada), assemelhando-se à música ligeira pela sua estrutura estandardizada (do arranjo geral às particularidades individuais), cuja relação entre forma e conteúdos é, por vezes, destituída de sentido elaborado para a experiência e, pelo seu imediatismo, não exige do ouvinte o esforço necessário para uma escuta deveras ativa e pensante, atenuando o impacto da crítica social visada na consciência de seu ouvinte (ADORNO, 1975, 1986, 1993). De acordo com Adorno e Horkheimer:

A rebeldia realista torna-se a marca registrada de quem tem uma nova ideia a trazer à atividade industrial. A esfera pública da sociedade atual não admite qualquer acusação perceptível em cujo tom os bons entendedores não vislumbrem a proeminência sob cujo signo o revoltado com eles se reconcilia (ADORNO; HORKHEIMER, 2006, p.109).

O rap evidencia o caráter de vulgaridade da música ligeira, visto que, mesmo que não estabeleça, ao que parece, uma relação totalmente alienada com os conteúdos, a disposição destes 
com a forma musical proposta demonstra uma postura sociológica de rebaixamento da consciência mediante uma postura musical de identificação a que a exigência da espontaneidade e da concentração do ouvinte (ADORNO, 1986, 2011). E pelo próprio papel atribuído à música, o de uma música engajada, esta perde sua autonomia estética, desdobrando-se nessa falsa relação a própria ideologia dominante (ADORNO, 1993). Resulta, para Adorno (2011), em uma relação cristalizada com a arte, uma não relação, de forma que "o que da linguagem artística autônoma da música resta no espírito do tempo é uma linguagem comunicativa. Esta permite algo semelhante a uma função social. Trata-se do resto que sobra da arte, quando o momento artístico nela já se diluiu" (ADORNO, 2011, p.114).

O funk, por sua vez, apresenta uma proposta mais festiva, de entretenimento, de celebração, de alegria e consiste em uma possibilidade de extravasar através do balanço corporal dançante, assim sendo, vem a ser um “[...] estilo de possibilidades de viver e expressar as pulsões, os desejos e as necessidades que caracterizam a condição juvenil” (DAYRELL, 2002, p.132). Condição juvenil que, dentro da realidade social mediada pela indústria cultural, a expressão das pulsões é a expressão da sua repressão e das poucas condições sociais para a sua sublimação e, deste modo, da condição juvenil alienada, restrita à aparente liberdade pela diversão (ADORNO; HORKHEIMER, 2006). À vista disso, esse estilo musical popular se destaca pelo seu caráter propiciador de lazer, exige poucos recursos materiais para a sua produção e para o seu consumo (custos, aparelhagens e técnica musical), estando mais vinculado a um tipo de estrutura musical auditiva atomizada, semelhante à escuta de massa, na qual "[...] a música não consiste numa estrutura de sentido, mas numa fonte de estímulo" (ADORNO, 2011, p.76).

A partir da perspectiva sociológica da música proposta por Adorno (2011), esse tipo de música atua, sobretudo, como conforto distrativo, não se lançando a qualquer tipo de escuta, tratando-se (e ainda mais a depender do tipo de modalidade de funk) de uma atitude musical descompromissada e destituída de qualquer sentido inteligível: tal como é concebida a noção de arte leve, assim como a música ligeira, o funk expressa deliberadamente "[...] a má consciência social da arte séria" (ADORNO; HORKHEIMER, 2006, p.112). O que retrata a própria condição do pensamento esclarecedor autônomo na contemporaneidade: o sentido de sua inteligibilidade é desprezado e destruído pela razão dominante.

Todavia, a diversão promovida pelo funk e pelas suas circunstâncias festivas como esperança de uma felicidade advinda de novos pertencimentos sociais e novos reconhecimentos 
identitários daqueles que são historicamente marginalizados pelo elitismo burguês, bem como por suas normas sociais subjetivadas pela coletividade, tal qual o rap, expressa o empenho de pessoas e de grupos sociais socialmente marginalizados para romper a sua invisibilidade social e cultural, mas que, contraditoriamente, contribuem para a manutenção da lógica e dos mecanismos da dominação social e da indústria cultural, que é a própria indústria da diversão (ADORNO; HORKHEIMER, 2006). Isto porque a diversão é tanto a recompensa da repressão libidinal e estratégia para a continuidade da ordem da produção e do lucro do mercado, como também embota os sentidos e a consciência quanto à " [...] antiga verdade de que a condição de vida nesta sociedade é o desgaste contínuo, o esmagamento de toda a resistência individual" (ADORNO; HORKHEIMER, 2006, p.114).

A função social de entretenimento é predominante e evidente no funk, o que, para Adorno (2011), em seu texto intitulado Função, “[...] assemelha-se então ao embuste, à falsa promessa de felicidade que se instala no lugar da felicidade mesma. Mesmo na regressão rumo ao inconsciente, a música funcional coincide ao Isso [Es] a que se dirige uma mera satisfação compensatória" (ADORNO, 2011, p.122). Quando, na verdade, o caráter da arte séria é a sua negatividade crítica, antítese social, a sua capacidade de sublimação estética não se conforma à renúncia do prazer, mas a denuncia em sua interioridade (ADORNO, 1993, 1975; ADORNO; HORKHEIMER, 2006) - "Eis aí o segredo da sublimação estética: apresentar a satisfação como uma promessa rompida. A indústria cultural não sublima, mas reprime" (ADORNO; HORKHEIMER, 2006, p.115).

O funk é exemplo manifesto da fetichização da música e, assim sendo, da consciência musical das massas, uma vez que esta se define, de acordo com Adorno (1975, p.177), “[...] pela negação e rejeição do prazer no próprio prazer". A escuta atomizada e descompromissada, característica do ouvinte de entretenimento (ADORNO, 2011), é uma representação mimética do todo social na fenomenologia da música ligeira, ou seja, da consciência coisificada: sua função de diversão é uma dimensão do ajustamento social alienado e que denuncia a ausência da aptidão à experiência, da experiência estética, visto que já não há mais relação direta entre sujeito e objeto (ADORNO, 1993, 1975; ADORNO; HORKHEIMER, 2006). Caso tivesse, a razão irracional da diversão seria desmascarada pela consciência de uma objetividade negativa e pelo seu consequente desconforto. E no que se refere à experiência estética, a arte autônoma é aquela que, além de contestar a ausência de prazer na sociedade do mal-estar e de vir a ser uma recusa social 
pela sua negatividade, é também a que transcende e se diferencia do todo pela sua autenticidade imagética, a qual propicia a possibilidade do prazer experimentado em confronto com a sociedade administrada que somente o aparenta por meios de sensações parciais e valorativas da felicidade, ou melhor dizendo, da falsa felicidade (ADORNO, 1993; ADORNO; HORKHEIMER, 2006). Sendo que, conforme Adorno:

\begin{abstract}
A arte considera negativa precisamente aquela possibilidade de felicidade, à qual se contrapõe hoje a antecipação apenas parcial e positiva da felicidade. Toda arte ligeira e agradável tornou-se mera aparência e ilusão: o que se nos antolha esteticamente em categorias de prazer já não pode ser degustador; a promesse $d u$ bonheur - foi assim que uma vez se definiu a arte - já não se encontra em lugar algum, a não ser onde a pessoa tira a máscara da falsa felicidade. O prazer só tem lugar ainda onde há presença imediata, tangível, corporal. Onde carece aparência estética é ele mesmo fictício e aparente segundos critérios estéticos e engana ao mesmo tempo o consumidor acerca da sua natureza. Somente se mantém fidelidade à possibilidade do prazer onde cessa a mera aparência (ADORNO, 1975, p.176, 177).
\end{abstract}

Diferentemente do rap, o funk possui maior apelo mercadológico, ajustando-se mais à estrutura musical padronizada, e atingindo outras populações de consumo além das periféricas: esse estilo musical é tocado tanto nas danceterias, nos programas televisivos e no rádio comercial, além do próprio circuito dos bailes funks "nos bairros, em quadras cobertas ou em escolas" (DAYRELL, 2002, p.130) das periferias - apresentando também diferentes modalidades (funk ostentação, proibidão, melody e o funk consciente). Cabendo cautela, por outro lado, quanto às generalizações totalizantes acerca deste gênero musical, uma vez que, para isto, caberia antes um trabalho de investigação e de análise mais aprofundado quanto à qualidade da experiência musical conforme cada modalidade de funk, circunstância de criação/produção, tipo de reações dos ouvintes, etc., além de se fazer a importante ponderação quanto ao desafio de transpor com objetividade "[...] o conteúdo subjetivo da experiência musical” (ADORNO, 2011, p.59). Deste modo, evita-se a reprodução do estigma social acerca desses gostos musicais.

Outro aspecto a ser debatido é o referente à maneira como o repertório musical tido como próprio das comunidades periféricas se inserem hoje nas mais diversas esferas sociais e como essas se relacionam com essa música, pois nos revela que para além do processo de conversão dessas estéticas musicais em bens culturais e de sua estandardização, essas também vêm a ser estéticas que provocam desconforto e desaprovação de parte da sociedade. O que desvela uma 
dimensão inerente às possíveis relações sociais de preconceito e de segregação, e, ao mesmo tempo, favorece a socialização, o sentimento de pertencimento e de representatividade identitária, atingindo, além disso, o gosto de outras classes sociais.

Ao contrário de uma perspectiva pejorativa usual, mais especificamente, o funk estabelece e expressa uma trama complexa de aspectos sociológicos e psicológicos, no que se refere, principalmente, ao processo de socialização dos jovens (em especial, os moradores das periferias) e, simultaneamente a isso, à discriminação social e também à influência da indústria cultural sobre esse material musical. Para Trotta:

Em quase todas as abordagens, o funk aparece como um vetor sonoro do processo de tensionamento de divisões sociais territoriais, econômicas e políticas, agente de um deslocamento de ideias sobre esse popular. (...) é uma das músicas brasileiras que mais recorrentemente tem sido associada à pobreza, favelas, marginalidades e periferias. Acionar o funk (como música, ideia, vocábulo ou estética) significa discutir diferenças de gosto e de estratos sociais, atravessadas por preconceitos e estereótipos que cercam o imaginário nacional sobre desigualdade. Ao mesmo tempo, o funk também evoca um forte componente de pertencimento etário e social, produzindo gostos compartilhados e espaço físico e imaginário para atividades de lazer de jovens de classes baixas. E, pelo viés da festa, da dança e da sedução, o funk transborda para fora de tais instáveis limites geográficos e sociais para ser experimentado também em outras esferas sociais e etárias, nos espaços de festas, shows e eventos públicos. Funk é música de "preto, pobre e favelado", mas é também música de casamentos de elite, de festas de classe média e de bailes de todas as classes. Com essa existência contraditória e sempre intensa, o funk é uma música que sempre aparece nos debates sociais como metonímia de jovens pobres em festa, disputando espaços e incomodando setores das elites nacionais (TROTTA, 2016, p.90, 91).

$\mathrm{Na}$ realidade brasileira, o funk, com sua estética musical historicamente vinculada ao contexto das periferias (DAYRELL, 2002; TROTTA, 2016), consiste em um estilo musical alvo de críticas das mais diferentes esferas sociais, especialmente quando atravessa as fronteiras marginais e morais que lhes são impostas, e quando ocupa espaços que lhe são socialmente renegados, uma vez que não se trata de um bem cultural que corresponda esteticamente aos preceitos de valor instituídos pela estima burguesa como valor de capital cultural elitizado, cuja mesma lógica contingente é também válida para as relações de segregação e de desigualdade social identificadas às comunidades periféricas, de tal modo que "[...] tudo o que não se ajustou 
inteiramente ou que fira os interditos em que se sedimentou o progresso secular tem um efeito irritante e provoca uma repugnância compulsiva" (ADORNO; HORKHEIMER, 2006, p.149).

As estéticas musicais periféricas não são ainda valorizadas como bens culturais, no sentido de se ter angariado uma importância social - de ser administrada uma atitude que "[...] vai desde o sentimento de respeito sério até um esnobismo vulgar" (ADORNO, 2011, p.63), ou seja, uma música que sirva de meio de consumo para se atingir e aparentar um certo status social -, algumas delas, em especial, o funk, atingem o gosto burguês no sentido de um uso oportuno e circunstancial quando em sua atitude musical de mero entretenimento festivo, tratando-se, pois, de uma fetichização musical ainda mais escrachada, evidenciando uma função de consumo pelo consumo de um divertimento breve e raso (ADORNO, 2011; ADORNO; HORKHEIMER, 2006). Revela-se, pois, a profundidade do alcance da indústria cultural, a qual não somente consiste nos mecanismos ideológicos do poderio econômico presentes na produção, no esgotamento e na dominação “[...] da aparelhagem inflada do prazer” (ADORNO; HORKHEIMER, 2006, p.115), como também é a expressão ideológica social interiorizada pelos seus consumidores, o interesse próprio às custas da dominação alheia pelo fetiche, a qual é também hierarquizada dentro do escopo das classes sociais, divididas hierarquicamente pelo seu poder de consumo e estima social, despedaçando qualquer possibilidade de relação e de uma intersubjetividade igualitária entre seres humanos iguais entre si por serem humanos (ADORNO; HORKHEIMER, 2006).

O funk é rebaixado valorativamente tanto pela qualidade duvidosa de sua elaboração estética musical, como também pela própria relação pautada pela ideia de hierarquia social e de fetichismo de uma mercadoria barata e irrisória, enervada também no tipo de relação estabelecida com a música de forma que o tipo burguês "comporta-se de modo hostil com relação às massas e age de maneira elitista [...] sem razão de ser, sente-se superior ao gosto da indústria cultural" (ADORNO, 2011, p.64, 65).

O caso dos "rolezinhos" que ocorreram entre dezembro de 2013 e janeiro de 2014 em shoppings centers de diversas cidades do Brasil, e que foi estreitamente atrelado ao funk pela mídia, é um outro exemplo de despeito social das pessoas residentes das periferias, bem como de seu repertório musical (TROTTA, 2016). Foram conjuntos de eventos, acompanhados pela cobertura das grandes mídias nacionais, e por elas diretamente associados ao funk, sem que isso, ao menos, tenha sido registrado efetivamente pela maioria das reportagens realizadas; bem como 
foram inferidos como algo de caráter negativo e perigoso, apresentados como ameaça de furto, violência e uso de substâncias ilícitas dentro dos espaços dos shoppings centers sem que isso tenha ocorrido de fato ou ao menos tenha sido provado (TROTTA, 2016). A partir de estudos recentes sobre o funk, foi identificada "[...] uma intensa veiculação da mídia [...]" (HERSCHMANN, 2005, p.19, apud TROTTA, 2016, p.91), por meio da qual tanto esse estilo musical como seus ouvintes foram investidos de caráter negativo, sendo associado a esses nas chamadas e manchetes jornalísticas a referência à figura do "pivete", à ameaça da onda dos "arrastões", o alarde quanto à violência generalizada dos morros. Perspectiva estereotipada que se evidencia de modo abismal, por exemplo, pela recorrente represália policial nos lugares onde se toca funk nas favelas, criminalizando-o, em que, como descrito por Trotta no caso das favelas cariocas:

\footnotetext{
Em todas as UPPs, uma das primeiras providências tomadas pelos comandantes locais é a proibição do funk (tanto dos bailes quanto também a execução pública em bares ou mesmo na porta de casa), fato que gera revolta entre os moradores jovens por aniquilar parte importante de seu repertório e atividades de lazer preferidas (Burgos et al. 2012, 68). As arbitrariedades dos comandantes das UPPs são engrenagens de um amplo processo de criminalização do funk (Lopes e Facina 2012, 197), que acompanham o gênero desde o início da década de 1990 (TROTTA, 2016, p.92).
}

Ao se sobrepor as formas predominantes de relações sociais aos dispositivos próprios dos repertórios culturais das periferias, identifica-se a constante estrutural dos mecanismos de controle e de dominação das normas sociais eleitas, que estreita a possibilidade de coexistência com o respeito, o direito e a inclusão social das especificidades da cultura popular das margens sociais. Sem contar, destarte, que parte do que se confere como da ordem do indivíduo residente das periferias é produzido pela própria estrutura da sociedade de classes e, por sua vez, da desigualdade e da exclusão social (ADORNO, 2004; ADORNO; HORKHEIMER, 1973). Estas, são previstas e transvestidas pelos mecanismos ideológicos da irracionalidade objetiva da teoria de mônades a benefício da preservação das condições para a realização dos interesses privados dos dominantes (ADORNO; HORKHEIMER, 2006). Na incapacidade do ajustamento ou do inconformismo social, a ameaça de seu aniquilamento pela discriminação, hostilidade e exclusão social se dá em prol, assim se faz crer, da ordem, segurança e bem-estar coletivo (FREUD, 2010). Deste modo que, conforme Adorno, “[...] negarse a colaborar lo convierte a uno en sospechoso y 
expone incluso a la venganza social a quien aún no necesita pasar hambre o dormir debajo de un puente" (2004, p.43).

Ao estacionar o olhar breve sobre o tipo e a qualidade dos recursos estéticos presentes nos estilos musicais do funk e do rap sem ao menos contextualizá-los, corremos o risco de ignorar ou rebaixar as necessidades que se fizeram intrínsecas a esse gosto musical, bem como de problematizá-las. A maneira como são construídos esses repertórios estéticos musicais também pode revelar, a partir da análise e da crítica sociológica de Adorno (2003, 2006, 2011), elementos da vida administrada que determinam a (pseudo)formação cultural da população das periferias e do todo social, seja por meio de uma análise histórica, seja também pela caracterização do fenômeno musical, permitindo-se, assim, uma ruptura das perspectivas monadológicas.

É necessário um estudo que permita esboçar uma compreensão integral da música, tanto das suas implicações sociais como das ideológicas, bem como a conscientização quanto à sua relação e conversão em mercadoria pela indústria cultural, fazendo dessa análise investigativa também uma crítica social. Isso deve ocorrer sobretudo na educação e na pesquisa educacional como forma de compreender as transformações profundas da formação cultural nas diferentes camadas sociais e que também se dão no interior do processo educacional de modo geral. Para tal, no tocante à infância e à juventude, mais especificamente, de acordo com Adorno (2006), esse entendimento crítico acerca da sociologia e psicologia dos comportamentos musicais específicos de uma época e de um determinado contexto sociocultural regional, como o caso das comunidades periféricas, é inerente à realização objetiva de uma educação para a experiência, enquanto conteúdos próprios do planejamento desta educação. Correlacionado a isso, para este autor:

[...] seria preciso estudar o que as crianças hoje em dia não conseguem mais apreender: o indescritível empobrecimento do repertório de imagens, da riqueza de imagines sem a qual elas crescem, o empobrecimento da linguagem e de toda a expressão (ADORNO, 2006, p.146).

Quanto ao processo de socialização das crianças e dos adolescentes, por sua vez, contíguo ao contexto territorial específico das periferias, pode-se constar que tais estilos musicais dispõemse como imagens estéticas possíveis de valorização e de reconhecimento de suas existências e de seu próprio repertório, em detrimento da flagrante invisibilidade social e da sua condenação midiática hegemônica; ao mesmo tempo, porém, que por assim ser, limita o repertório imagético 
e a sua riqueza, favorecendo, à contramão, “[...] o empobrecimento da linguagem e de toda a expressão" (ADORNO, 2006, p.146), bem como a capacidade de sua apreensão perceptiva e reflexiva sobre o mundo e sobre si mesmo.

Mesmo que não haja condições propícias e suficientes para uma criatividade e expressividade autônoma das individualidades dentro dessa coletividade, essas existências não se deixam calar, mas sim, se fazem ouvidas e vivenciadas, seja pelo som pesado e mínimo do rap, seja pelas batidas repetitivas e marcantes do funk. A sonoridade marcante e até agressiva, se assim o é, é reflexo tanto da pseudoformação e da semicultura em sua própria formação estética, como também é um modo ressentido de atacar as barreiras sociais estabelecidas que os excluem (ADORNO; HORKHEIMER, 2006). Aproxima-se de alguns dos elementos proponentes da luta por reconhecimento: a busca pelo direito à existência, pelo respeito e pela formação da autoestima por meio da criação de estéticas musicais que acolham a sua realidade enquanto juventude, enquanto comunidades periféricas, e que propiciem espaços de vivência cultural, protagonismo estético e de sociabilidade (HONNETH, 2003, 2013). Por outro lado, restringem-se ao processo de autoconservação pelo reconhecimento de sua existência coletivizada em detrimento da própria individualização pela experiência (ADORNO, 2005; ADORNO; HORKHEIMER, 2006).

Essa psicodinâmica é visibilizada e confirmada por meio de produtos culturais de um nova estética periférica, pelo fortalecimento de uma coletividade desfavorecida por meio da socialização e do entretenimento propiciados e, sendo assim, mantém o predomínio da ordem da adaptabilidade social e as mesmas condições operantes da cultura administrada. No entanto, não se pode furtar ao fato de que apesar de carregarem estigmas sociais, críticas musicais contundentes acerca de sua inconsistência estrutural e de seu caráter de rebaixamento à própria essência social (o que Adorno caracteriza como vulgar da postura musical) - recaindo à ordem da música ligeira -, resistem ao conformismo da invisibilidade e do desrespeito social pelo simples fato de existirem e, por meio delas, faz-se conhecida a juventude periférica, ou a ressignificação dos pressupostos feitos sobre esta. Afrontam pelo incômodo gerado aos consumidores culturais elitistas, ou mesmo do ouvinte do ressentimento (ADORNO, 2011), e, deste modo, tensionam o processo estrutural de sua invisibilidade social.

Para tanto, ao que diz respeito ao campo educacional formativo, não passa despercebida a ausência de condições objetivas e sociais para uma educação que propicie a conscientização e o 
pensamento criador dessa população de crianças e jovens, cujo contexto comunitário, socialmente marginalizado, encontra-se ainda mais desfavorecido de políticas públicas de educação e cultura embasadas e consistentes para a formação de sujeitos aptos à experiência (ADORNO, 2006). Os quais, distanciados violentamente da possibilidade e do direito básico à educação, ressentem-se com tudo aquilo que não pode ter garantido, inclusive a própria capacidade para a experiência formativa, negando inconscientemente as condições para tal e bastando-se a uma estética identitária em contra resposta compensatória (ADORNO, 2006; ADORNO; HORKHEIMER, 2006).

Pelo estado de exclusão vivido, esses jovens reagem a esta, porém, de modo a se distanciar ainda mais da autodeterminação e da formação cultural, compensando-as a partir do convencimento de produzirem reativamente arte e cultura por si mesmos, quando, na verdade, "Falar em cultura foi sempre contrário à cultura" (ADORNO; HORKHEIMER, 2006, p.108). O que expressa, assim sendo, uma contradição em relação à formação da consciência sensível e intelectual. De acordo com Adorno (2006), no contexto duradouro da dominação social, da semicultura e da pseudoformação:

Provavelmente em um número incontável de pessoas exista hoje, sobretudo durante a adolescência e possivelmente até antes, algo como uma aversão à educação. Elas querem se desvencilhar da consciência e do peso de experiências primárias, porque isto só dificulta sua orientação. Na adolescência desenvolvese, por exemplo, o tipo de que afirma - se posso recorrer mais uma vez à música ---: “A época da música séria já passou; a música de nosso tempo é o jazz ou o beat". Isto não é uma experiência primária, mas sim, se posso usar a expressão nietzschiana, um fenômeno de ressentimento. Essas pessoas odeiam o que é diferenciado, o que não é moldado, porque são excluídas do mesmo e porque, se o aceitassem, isto dificultaria sua "orientação existencial", como diria Karl Jaspers. Por isto, rangendo dentes, elas como que escolhem contra si mesmas aquilo que não é propriamente sua vontade. A constituição da aptidão à experiência consistiria essencialmente na conscientização e, desta forma, na dissolução desses mecanismos de repressão e dessas formações reativas que deformam nas próprias pessoas sua aptidão à experiência. Não se trata, portanto, apenas da ausência de formação, mas da hostilidade frente à mesma, do rancor frente àquilo de que são privadas. Este teria de ser dissolvido, conduzindo-se as pessoas àquilo que no íntimo todas desejam (ADORNO, 2006, p.150).

No contexto específico das periferias, vem-se observando também o avanço da apropriação mercantil sobre esses territórios - para além do que lá já está determinado e instituído no que toca à sua universalidade por meio da indústria cultural -, visto que esses estão 
conquistando maior visibilidade social, especialmente por meio das atividades artísticas e culturais promovidas, como, por exemplo, os saraus culturais e os movimentos e coletivos culturais organizados pelos seus residentes: "a periferia é hoje valorizada como lugar onde se produz cultura, e não somente violência e marginalidade" (TOMMASI, 2013, p.19).

Nesse contexto social, a arte e a cultura estão atreladas enfaticamente com o seu caráter político de formação de consciência, de resistência e de luta por reconhecimento, no entanto, essa mesma força não se exime do interesse econômico, seja no tocante à disputa pelas políticas de fomento à cultura das periferias, às formas de captação de recurso, seja pelo empreendedorismo econômico ou até pelas formas de gestão social adotadas. Foi constatado, por exemplo, nas favelas cariocas uma “[...] proliferação de cursos, cursinhos e oficinas que se utilizam de alguma linguagem artística para promover o chamado 'protagonismo' juvenil, a 'elevação da autoestima' e a "conquista da cidadania"” (TOMMASI, 2013, p.20). Em contiguidade a isso, os projetos sociais instalados nessas áreas também compartilham de alguns dos objetivos pré-estabelecidos por outros tipos de organizações sociais, reduzindo muitas vezes a arte e a cultura a meios estéticos para o enfrentamento e resolução de problemas sociais, levando, consequentemente, à sua instrumentalização (PERES et al., 2018, TOMMASI, 2013).

Quanto aos próprios moradores das periferias, diante da realidade de pobreza e das condições de trabalhos oferecidas a eles (baixos salários, trabalhos informais, direitos empregatícios muitas vezes não concedidos pelo empregador, subempregos, etc.), em especial, aos jovens, esses, em decorrência, passam a ter poucas expectativas e perspectivas positivas quanto ao seu futuro profissional (DAYRELL, 2002), vendo na música, assim como nas outras modalidades artísticas, a possibilidade não só para o entretenimento, para se alcançar status social, para a socialização e para a formação identitária, mas também como um campo de profissionalização, de possibilidade de "inserção na universidade ou nas oportunidades de emprego" (PERES et al., 2018, p.65), como também, meio para a autonomia financeira, como é o caso, por exemplo, da formação de grupos musicais de rap e de funk, dos DJs e MCs (DAYRELL, 2002; TAKEUTI, 2010).

É identificada uma relação de contraste na concretização do sentido político das atividades artísticas e culturais que acontecem nas periferias: os conflitos e denúncias estéticas, a afirmação política de pertencimento territorial, a formação cultural e a coexistência com suas ambivalências, em especial, a padronização estética, a mercantilização da cultura e a sua 
instrumentalização, como também, o desenvolvimento de práticas educativas presas "nas malhas da semiformação", impedindo a diferenciação do indivíduo (ADORNO, 2005). Dificilmente seria de outra forma, pois “[...] estas são tão fortes a partir da produção, seu estabelecimento está tão de acordo com os interesses decisivos e se adequam tanto às manifestações culturais atuais, que sua representatividade se impõe, mesmo sem a chancela da estatística” (ADORNO, 2005, p.7).

A educação musical proposta pelo projeto social participante também compreendeu, em dois dos objetivos específicos estipulados pela equipe coordenadora, e tal como foi enfatizado em todas as entrevistas, "favorecer o acesso às escolas de aprofundamento musical" e "facilitar os meios de profissionalização musical aos interessados", segundo consta em seu website, e como também se pode verificar nos conteúdos das entrevistas, como nos exemplos a seguir:

Uma outra questão, acho que está ligada à profissionalização: talvez, num futuro próximo, da própria banda dos alunos, sabe, que é onde eles têm feito cada vez mais intercâmbios com artistas, trocas muito interessantes.. É, acho que se posicionando mesmo, musicalmente, artisticamente, no mercado. Então, acho que, a partir do momento que você tem quem está afim de fazer no caso, muitas crianças estão afim de fazer, é, com recursos, com pessoas que estão aqui do lado para apoiar. Acho que isso pode ser uma possibilidade bem importante (A., coordenadora pedagógica, entrevista 1, Anexo D).

[...] é totalmente transformador, do destino até de uma criança que de repente ela iria pro tráfico, para as drogas, e vai estar sendo um professor de música (C., presidente, entrevista 3, Anexo D).

Tais objetivos estão estreitamente vinculados, em resposta, à perspectiva desses educadores quanto à realidade familiar e social de seus alunos, o que, nesse caso, diz respeito mais especificamente "à falta de oportunidades", dentre elas a de emprego e a de garantia de sustento próprio e o da família, como também parecem dispor como forma possível para compensar as desigualdades sociais. Essa situação possui certa veracidade ao corresponder com os dados do mapa da vulnerabilidade social consultado quanto à densidade de famílias beneficiárias de programas de transferência de renda (PREFEITURA DE SÃO PAULO, 2012, 2016). Entretanto, finalidades pré-estabelecidas à arte e à educação estética como as postas acima mais respondem às forças da adaptabilidade social, ao conformismo indireto em se bastar à autoconservação uniformizadora e, assim sendo, a uma falsa individuação, como também, à instrumentalidade técnica do que aos princípios ativos para uma possível experiência formativa, 
dinâmica própria da cultura administrada e da indústria cultural: a “[...] dialética da formação fica imobilizada por sua integração social, por uma administração imediata. A semiformação é o espírito conquistado pelo caráter de fetiche de mercadoria” (ADORNO, 2005, p.11).

Ao buscar romper com a realidade de privilégios burgueses quanto ao monopólio cultural por meio da popularização da cultura nas presentes circunstâncias, ou daquilo que vem a ser entendido e valorizado como democratização desta última, acaba por mantê-los, mesmo que disfarçadamente na aparente democratização cultural, uma vez que "quem compreende o que é poesia dificilmente encontrará um posto bem pago como autor de textos publicitários" (ADORNO, 2005, p.6).

A justaposição de interesses mercantis e de sobrevivência são antagônicos aos da formação cultural, de maneira que os primeiros "[...] nada têm a ver com os valores objetivos, com os sentidos dos produtos" (ADORNO; HORKHEIMER, 2006, p.102), submetendo a arte autônoma e a educação ao seu esvaziamento e à sua redução em meros aparelhos mecânicos, acessórios da manutenção da ordem dominante, ao invés de romper com esta pela formação das capacidades humanas de reflexão e crítica (ADORNO, 2006; ADORNO; HORKHEIMER, 2006).

Cabe, portanto, aqui, a mesma indagação feita por Becker em suas ricas trocas reflexivas que teve com Adorno (2006) ao pensarem sobre as condições sociais para a educação de seu tempo e sobre as possibilidades para uma educação para a formação emancipatória, de acordo com ele, replicamos tal questionamento: "Onde fica em todo este sistema aquilo que é espontâneo, aquilo que é criativo?” (BECKER apud ADORNO, 2006, p.145).

\subsection{A arte engajada e a identidade cultural periférica: o risco do passo em falso}

Pelas disposições discursivas e pelas formas de atuação e intervenção propositivas dos coletivos e movimentos culturais mapeados, pela leitura de autores contemporâneos sobre as experiências musicais dos ouvintes de funk e do rap, e pela consideração do caráter interventivo de projetos socioeducativos e culturais, pôde-se identificar que, apesar das evidentes especificidades e finalidades quanto às suas respectivas formas de relação com a arte e com a cultura, em todas essas esferas busca-se, cada qual à sua maneira, responder às problemáticas estruturais de desigualdades, invisibilidade, discriminação e exclusão social das comunidades periféricas e que, dentre os diferentes modos de enfrentamento dessa realidade hostil (da crítica 
social à ostentação estereotipada), tanto os coletivos e movimentos culturais como essas produções musicais buscam por meio da arte e da cultura criar espaços para a socialização, para a democratização dos bens culturais, para a exultação do próprio repertório local, para a construção da auto estima comunitária e individual; também, buscam desconstruir preconceitos e estereótipos sociais, prover condições para a expressividade e criatividade, para a denúncia, reflexão e crítica social, para garantia dos direitos universais não garantidos às populações das periferias. É evidente como as produções e intervenções artísticas e culturais, e suas práticas educativas correspondentes, convergem com fins específicos da luta social, principalmente no que diz respeito à luta por reconhecimento e à resiliência: a arte enquanto função social e política.

A arte e a cultura, pela sua potencialidade expressiva e de oposição ao todo social, são campos de conhecimento favoráveis para se produzir maior visibilidade, valorização e respeito tanto às causas sociais desses grupos, como aos repertórios estéticos e culturais específicos dessas comunidades (GOHN, 2009; 2015) de modo a se fazer oposição ao discurso dominante e, assim sendo, à "história única", que inviabiliza a formação de uma intersubjetividade por meio da qual seja possível "[...] reconhecer-se reciprocamente como pessoa de direito" (HONNETH, 2003, p.138), havendo, pois, pouca “[...] possibilidade duma relação entre iguais” (ADICHIE, 2009), semelhante à arte engajada.

Antagônicos às determinações sociais opressoras e excludentes, esses grupos buscam desconstruir o estigma e a invisibilidade social projetados sobre as periferias justamente pelo evidenciamento artístico do seu repertório cultural, por meio da qual fazem críticas e denúncias sociais acerca de conteúdos temáticos legítimos, como também buscam dar visibilidade às suas potencialidades comunitárias, convergindo a um processo de formação de uma identidade cultural independente da periferia. Isso de modo que a arte e a cultura são consideradas, sobretudo, por um tipo de compreensão que elege enfaticamente a sua potencialidade política social, cujos conteúdos estéticos podem manifestar imediatamente as suas intenções. Dentre essas, o evidenciamento valorativo de um conjunto de características (étnicos raciais, de gênero, da cultura popular, da história e da memória, por exemplo) socialmente hostilizadas e que, como forma de enfrentamento social, essas são condensadas em um novo produto: a identidade de "ser periférico". Sendo assim, as práticas interventivas e educativas artísticas e culturais, a identidade de ser da periferia e a arte engajada encontram-se afiliadas. 
O processo da formação identitária se constitui por meio de relações grupais nas quais seus membros se reconhecem, se sentem representados, resguardados e fortalecidos por essa coletividade, compartilhando com os demais algo em comum. No tocante ao contexto territorial do presente estudo, as comunidades periféricas compartilham entre si as realidades determinadas de desigualdades sociais, de invisibilidade e exclusão social. Essas problemáticas sociais se encontram historicamente vinculadas ao fator étnico racial, sendo as periferias onde se concentram as maiores densidades de pessoas afrodescendentes na cidade de São Paulo (IBGE, 2010 apud CEERT, 2015); isso, por sua vez, se articula com a história e com a memória do genocídio negro desde os tempos da escravidão, e também com a história de resistência dos quilombos e com a herança cultural e religiosa de matrizes africanas. São repertórios bastante evidenciados na divulgação de parte dos coletivos e movimentos mapeados, bem como da cultura hip hop, cujos conteúdos estéticos, somados às peculiaridades desses territórios, transvestiram-se fortemente em uma identidade da cultura popular periférica de modo que por sua visibilidade, valorização e reconhecimento, as próprias pessoas que lá residem também o sejam, uma vez que essa identidade, em tese, os compreende e os representa. Estabelece-se, assim, nessa relação disposta entre arte, cultura e luta social, uma mobilização identitária ativa e positivada de "ser periférico", tal como foi constatado por Tommasi:

O "fazer por nós mesmos" em vez de esperar que o poder público supra a falta de equipamentos e de serviços culturais que caracterizam os bairros de periferia; a ideia de resgate, a valorização da identidade territorial periférica; a afirmação da autonomia, que se expressa também, às vezes, na recusa a se submeter à normatização implícita nos editais, a denúncia das condições precárias dos serviços públicos da região, o tema do desemprego sempre presente, do trabalho precário, da exploração, são conteúdos importantes da produção cultural periférica paulista. Expressões como "o mundo é diferente da ponte para cá" (a ponte é a que cruza a marginal, na zona sul da cidade), ou "periferia é periferia em qualquer lugar", extraídas das letras dos Racionais Mc's, são paradigmáticas dessa postura política. Afirmar com orgulho de "ser da periferia" é uma experiência inédita. Nesse sentido, ser ou não da periferia é um dado fundamental que legitima a fala. [...] $\mathrm{O}$ acionamento identitário dos artistas periféricos paulistas opera uma afirmação política enquanto reivindicação do pertencimento territorial a uma periferia simbolicamente unificada como alteridade, contraposta ao centro dominante; apela para o reconhecimento político de uma alteridade positivada. Representa, como eles dizem, um "ato de resistência”. (TOMMASI, 2013, p.26) 
Os processos identitários das periferias, mais especificamente, ocorrem no cotidiano dos bailes funks, nos grupos musicais de rap, na cultura hip hop, na aparição exponencial de DJ's e MC's provindos das favelas, dos morros e das quebradas; na própria formação grupal dos movimentos e coletivos artísticos e culturais das periferias, nas gírias e modismos locais, nas tendências estilísticas de denúncia social e também por meio das práticas educativas propostas por projetos sociais comunitários, entre outros, além do próprio núcleo familiar, religioso etc. Dinamismos que aparecem conjuntamente atrelados aos dispositivos modernos de meio de comunicação, como as tecnologias de audiovisual e a própria internet (websites e redes sociais), bem como estruturam-se, por exemplo, nas propostas informais que visam à integração comunitária por meio da poesia de rua nos saraus culturais, onde todos têm o direito para suas declamações no modelo "microfone aberto". No entanto, concomitantemente a isso, ao determinar uma estética particular identitária independente da cultura dominante, corre-se o risco de, contraditoriamente, converter-se a esta última e reproduzi-la pelo tipo de relação estabelecida com a arte (como produção cultural) e pelo tipo de relações grupais correspondentes.

A formação identitária evidencia, pela necessidade desse tipo de movimento grupal a própria condição do Eu enfraquecido determinado pela estrutura social da dominação, que impedido de autodeterminar-se, recorre às mínimas condições de sobrevivência que mais se aproximariam de um processo de individuação, mas que, na verdade, se limitam à autoconservação. Ao mesmo tempo que a identidade consiste em uma tentativa de diferenciação grupal da sociedade massificada e excludente, esta não se dá pela consciência emancipada, mas sim por ideais exteriores coletivistas-reacionárias (ADORNO, 2006); do mesmo modo, ao buscar se opor ao ajustamento social homogeneizante, ao fazê-lo pela ideia de uma identidade positivada e valorativa, esta mais se vincula a uma contingência de reconhecimento e respeito social mediante a sua aceitação do que pela possibilidade de oposição singular ao todo social, sendo esta última possibilidade de um tensionamento elementar de uma sociedade democrática de fato e de direito. Logo, o dinamismo grupal subjacente à identidade acaba por, paradoxalmente, recair na reprodutibilidade de mecanismos da dominação social: a adaptabilidade, a indiferenciação e a racionalidade administrativa. Impõe sobre o grupo uma representatividade estática e genérica como na indústria, fixa "cada um no estágio do mero ser genérico" (ADORNO; HORKHEIMER, 2006, p.128) - em detrimento das diferenças qualitativas de cada membro e da condição da autonomia individual para autodeterminar-se dentro desse grupo. Na totalidade da identidade, o 
sujeito singular deixa de ser considerado com a devida atenção e respeito. Ou seja, a ênfase recai mais sobre a identidade do que sobre a individuação, convergindo com o domínio do aparato da racionalidade técnica como forma de se administrar os meios de um enfrentamento social. O que significa ser uma forma de resistência grupal contraditória, pois nesta não há uma verdadeira emancipação. Para Adorno, em Cultura y administración:

Las organizaciones tendentes a fines dentro de la sociedad antagónica, han de perseguir necesariamente fines particulares: al precio de los intereses de otros grupos. Por eso se ven obligadas al endurecimiento y la concretización. Si fueran a la baja, de cara a sus miembros y a las pretensiones inmediatas de éstos, siempre de un modo manifiesto, entonces no serían capaces de funcionar (ADORNO, 2004, p.117).

A frágil, ou então, a ausência de compreensão quanto à dialética entre autonomia e dominação, e quanto a tudo a que essa remete, corrobora com a cegueira das boas e legítimas intenções de reconhecimento mútuo, respeito social e autonomia humana dessas, visto que, como se pôde verificar, isso impede a autoconscientização quanto à identificação de mecanismos administrativos, próprios da racionalidade técnica (inerente à razão dominante), presentes na práxis e nas relações estabelecidas entre esses grupos e seus membros e, em decorrência, dá-se a saber uma soberania do universal sobre o particular, situação contrária ao que se propõe a resistência à dominação social pela autonomia e, assim sendo, pela emancipação. Para Adorno:

Numa democracia, quem defende ideais contrários à emancipação, e, portanto, contrários à decisão consciente independente de cada pessoa em particular, é um antidemocrata, até mesmo se as idéias que correspondem a seus desígnios são difundidas no plano formal da democracia. As tendências de apresentação de ideais exteriores que não se originam a partir da própria consciência emancipada, ou melhor, que se legitimam frente a essa consciência, permanecem sendo coletivistas-reacionárias. Elas apontam para uma esfera a que deveríamos nos opor não só exteriormente pela política, mas também em outros planos muito mais profundos (ADORNO, 2006, p.142).

Se mantida a ideia de uma identidade independente mas que funciona com base em uma estrutura das tendências, generalizações e da padronização em prejuízo à possibilidade de uma relação coerente de sentido com as particularidades individuais daqueles que compõem tais grupos e manifestações coletivas, bem como de uma psicologia que se proponha à real 
democracia, a substância de sua resistência será mais volátil do que se aparenta ser. Concordante com Adorno:

Su independización se la impone a la organización la autoconservación, mientras que ella simultáneamente se distancia mediante esta independización de sus objetivos y de los seres humanos de los que se compone. Al final entra necesariamente en contradicción con éstos para poder perseguir sus objetivos de un modo adecuado (ADORNO, 2004, p.117).

A dialética entre autonomia e dominação é o aspecto crucial para se pensar sobre a disposição histórica entre o particular e o universal e, deste modo, entre o caráter humano criador e a coisificação humana, ou seja, a própria disposição contraditória inerente à formação do indivíduo pensante enquanto diferenciação autodeterminada da coletividade. Nos levando a nos confrontar com a constatação de que, conforme Crochik (2001, p.20), “como o indivíduo só pode se diferenciar pela introjeção da cultura e essa é contraditória por envolver, em um mesmo movimento, tendências regressivas e emancipatórias, ele só pode se desenvolver mediado por essa contradição". E se tratando da realidade vigente, a do mundo administrado, não podemos nos furtar quanto aos mecanismos operantes da razão dominante; na verdade, é preciso conscientizarse quanto à sua perspicácia e alcance subjetivo, não podendo subestimá-los ao que se refere à sua influência na formação da racionalidade reacionária e ativista, a qual pode sucumbir a uma falsa consciência esclarecida e democrática e de forma oculta e subjacente a esta pode estar a operar a racionalidade administrativa. $\mathrm{O}$ mesmo pode ocorrer com a arte, a cultura e a educação.

A arte, a cultura e a educação apresentam potencialidades políticas e sociais para a formação do sujeito autônomo, para a formação do pensamento e para a formação cultural, uma vez que essas são campos de forças que reclamam a dimensão do particular contra o universal, seja quando essas dimensões estejam conciliadas entre si, fundamento de uma sociedade democrática operante; seja quando o universal se impõe sobre o singular, irreconciliável a este último, o que caracteriza a ordem da dominação social (ADORNO, 1993, 1995, 2004, 2006). Sendo que, como se pode observar, esta última disposição é incompatível à arte, à cultura e à educação quanto à condição de sua liberdade, espontaneidade, experiência, autenticidade e reflexão crítica, ou seja, sua autonomia.

Por se tratarem de objetos históricos, a necessidade desses campos de saber transformamse conforme o seu momento social, que, a depender das normas e da racionalidade do todo social, 
eles podem passar da esfera do pensamento criador, sensível e crítico para a sua conversão em outra coisa dominada e esvaziada da sua potencialidade de resistência pela autodeterminação. Deste modo, de acordo com Adorno (2004, p.121), “[...] la reproducción de la fuerza de trabajo se sigue del estándar cultural históricamente conseguido en cada caso, no es ninguna categoría natural estática". No entanto, o risco da compreensão desses conceitos é o de tomá-los de forma dissociada da história e dos seus determinantes sociais, como invariantes fixos, e, portanto, sobrepor essa compreensão à própria práxis possível, em detrimento da consciência crítica quanto à sua real objetividade e consistência, tal como ocorre no esclarecimento positivista (ADORNO; HORKHEIMER, 2006). Em relação a isso, segundo Crochik, "[...] no tocante à formação, não deve unicamente se voltar ao material cultural existente mas também ao tipo de relação que somos obrigados a desenvolver com eles" (ADORNO, 2001, p.30).

$\mathrm{Na}$ sociedade vigente, a razão dominante do capitalismo tardio opera por meio da racionalidade administrativa, a qual submete a tudo e a todos à heteronomia, ao sentido de utilidade e ao controle de fábrica (ADORNO, 2004). Nesse contexto, a arte e a cultura são convertidas em forças estéticas produtivas e em bens culturais - da autonomia estética ao entretenimento -, a potencialidade da educação para a formação de indivíduos pensantes é reduzida à pseudoformação, a uma educação domesticada e ideológica, cuja racionalidade, contraditoriamente, passa ser a mesma da racionalidade administrativa: a aptidão a experiências formativas e o pensamento esclarecido como exercício permanente deixam de ser objetivos reais, tornam-se apenas um palavrório mimético desses, fins aparentes. O que representa, neste momento da sociedade regida pelo capital, o domínio dos interesses econômicos, bem como sua irracionalidade adjacente, sobre a humanidade, segundo Adorno (2004, p.121), “[ ...] frente al beneficio en el sistema total, lo útil en sí, que no fue jamás algo inmediatamente favorable para los seres humanos, se convirtió en algo secundario, arrastrado por la maquinaria".

Isso pode ser analisado, por exemplo, pelos tipos de organizações grupais e pelas relações nelas estabelecidas, como também, pelo tipo de relação estabelecida com a arte e pela sua consistência estética. Considera-se que, em todas essas dimensões de relações e práxis, a qualidade da relação entre o universal e o particular, entre o todo e a unidade, é mediada por determinantes sociais e psicológicos - sendo que, na verdade, esses são indissociáveis entre si. Para a resistência objetiva da dominação social e do autoritarismo, é preciso não somente ter consciência dos seus aspectos sociológicos mas também conscientizar-se quanto à sua psicologia. 
Como propõe Adorno (2006) no tocante à educação após Auschwitz para o esclarecimento crítico, faz-se necessário pensar a realidade de forma a se produzir "[...] um clima intelectual, cultural e social que não permite tal repetição; portanto, um clima em que os motivos que conduziram ao horror tornem-se de algum modo conscientes" (ADORNO, 2006, p.123). Para isso, há a necessidade da própria auto reflexão para se pensar sobre a real coerência de sentido e objetividade da práxis. Questão relativa, por sua vez, ao conhecimento teórico e ao pensamento crítico para que, deste modo, seja desarmado o predomínio da irracionalidade racionalizada na práxis e para que se evite cair no convencimento quanto às realidades ilusórias da transformação social que se pretende atingir. A resistência e a transformação social objetivas não são possíveis sem a formação do Eu e sem o pensamento. Que, de acordo com Adorno:

O mundo, que a razão subjetiva tendencialmente só se limita ainda a reconstruir, na verdade deve ser continuamente transformado conforme sua tendência à expansão econômica e, contudo, sempre permanecendo o que é. O que mexe com isso é amputado do pensar: sobretudo, a teoria que quer algo mais que reconstrução. Dever-se-ia formar uma consciência de teoria e práxis que não separasse ambas de modo que a teoria fosse impotente e a práxis arbitrária, nem destruísse a teoria mediante o primado da razão prática...Pensar é um agir, teoria é uma forma de práxis; somente a ideologia da pureza do pensamento mistifica este ponto. O pensar tem um duplo caráter: é imanentemente determinado e é estringente e obrigatório em si mesmo, mas, ao mesmo tempo, é um modo de comportamento irrecusavelmente real em meio à realidade. Na medida em que o sujeito, a substância pensante dos filósofos, é objeto, na medida que incide no objeto, nessa medida, ele é, de antemão, também prático. Mas a irracionalidade sempre novamente emergente da práxis - seu protótipo estético são as ações casuais com as quais Hamlet realiza o planejado e fracassa na realização - anima incansavelmente a ilusão de uma separação absoluta entre sujeito e objeto. Quando se simula que o objeto é pura e simplesmente incomensurável em relação ao sujeito, um cego destino captura a comunicação entre ambos (ADORNO, 1995, p.204, 205).

No tocante à perspectiva sociológica da arte, por sua vez, isso se transpõe na tênue relação entre arte e ideologia, e no caso da arte engajada, na dialética entre o elemento social e do em-si das obras de arte (ADORNO, 1993). À luz da compreensão conceitual dialética em Adorno (2011), a de que "a criação artística submete-se às leis gerais de desenvolvimento social, mas possui também, como forma especial de consciência, suas particularidades, suas leis específicas" (FEDOSSEJEN et al., 1984, p.404 apud ADORNO, 2011, p.30), reflete-se sobre a estética, a arte e a cultura a partir da sua fenomenologia social, no que diz respeito, sobretudo, ao tipo de 
relações estabelecidas entre o todo social e suas particularidades (do indivíduo-criador-artista, da própria obra e da pessoa-espectador). Assim sendo, abre-se um campo investigativo vasto e complexo sobre o tipo (consistência e coerência de sentido) das relações entre a autonomia das leis específicas da arte e o uso da técnica; a real capacidade estética para a reflexão crítica e o conceito de esclarecimento adotado; seu valor de uso enquanto crítica social (além mercadoria) e o valor de troca; a experiência estética e a produção/consumo cultural, e, por fim, se há possibilidade de formação de uma consciência sensível no contexto da realidade contemporânea, marcada pelo empobrecimento da experiência e pelo predomínio das forças produtivas. Cabe, pois, indagar se a elaboração artística e as manifestações culturais autênticas ainda são possíveis na sociedade do capital, onde, segundo Adorno (2011, p.16), “apenas não se paga para respirar!”, sem que estejam totalmente entregues ao monopólio cultural burguês e à sua administração; a conversão da dimensão estética reflexiva crítica para a de produção cultural; a normatização global das estéticas; o esclarecimento pragmático; o valor de uso reduzido à utilidade de consumo e, por assim dizer, substituído pelo valor de troca; o entretenimento e a semicultura (ADORNO; HORKHEIMER, 2006). Nos levando, ademais, a também problematizar a ideia de arte engajada à luz da compreensão de arte autônoma, visto que, para Adorno:

A ambigüidade das obras de arte como obras autônomas e fenômenos sociais deixa facilmente oscilar os critérios: as obras autônomas induzem ao veredicto da indiferença social e, por fim, do espírito reacionário e sacrílego; inversamente, as que, no plano social, julgam unilateralmente e de um modo discursivo negam assim a arte e negam-se, com ela, a si mesmas. A crítica imanente deveria eliminar tal alternativa (ADORNO, 1993, p.277).

A análise sociológica do material estético permite identificar as formas pelas quais a sociedade é organizada e regida: ao compreender as formas estéticas como "conteúdo sedimentado" (ADORNO, 1993), elas se revelam enquanto microcampos históricos, permitindo identificar, em uma análise aprofundada desta questão, as reminiscências e traços ideológicos dominantes de cada período, também determinantes das tendências, estilos e das normas estéticas adotadas - além daquilo que transcorre, mantém-se e evolui ao longo da história, em uma leitura e uma análise de escopo longitudinal. No contexto social regido pela cultura administrada, a padronização estética reproduz o modo de produção em larga escala da indústria, evidenciando o empobrecimento da experiência e, por fim, a própria dominação social sobre qualquer 
possibilidade de individuação autônoma (tanto do artista, como da própria obra), rompendo com a possibilidade de coexistência dos elementos constitutivos da arte: sua liberdade, autonomia e autenticidade, o seu caráter de negação e recusa; a de conter em si o conteúdo de uma verdade e a imaginação.

Mediada pela indústria cultural, a arte é revestida pelos grilhões dos determinismos de produção, sua autonomia é tomada pela soberania da intenção subjetiva do sujeito burguês, e a relação correspondente entre forma e conteúdo é esvaziada de sentido, passando para um trabalho estético enquanto produção cultural para o entretenimento - para a embriaguez dos sentidos fustigados pelo trabalho por meio da falsa promessa de felicidade pela diversão -, que ao invés de um envolvimento ativo e refletido, para o qual exige o esforço do pensamento, é reduzido a reações manipuladas e condicionada a fins práticos por meio de esquematismos subjacentes à lógica do consumo (ADORNO; HORKHEIMER, 2006), que, para tal, adota um sistema de "mecanismos de resposta totalmente antagônico ao ideal de individualidade numa sociedade livre" (ADORNO, 2011, p.120). Tal imperativo da cultura administrada leva, assim, ao desenvolvimento de relações aparentes com a arte e com a cultura ao (pseudo)formar receptores passivos e ao produzir e administrar uma arte produto, compensatória da energia pulsante extraída como força de trabalho (ADORNO, 2011; ADORNO; HORKHEIMER, 2006).

No trato da música popular, como o funk e o rap, isso vem a se expressar pela imitação e repetição de padrões musicais tidos como hits de sucesso, o seu agenciamento, a sua promoção no mercado cultural (plugging) e a sua glamourização, provocando um estado de cristalização de estímulos e afunilando-se em uma identidade estética para o entretenimento e não mais para a espontaneidade de uma crítica social de fato, uma vez que "[...] a ideologia dominante impede a consciência de perceber que ela (a música) não é experimentada” (ADORNO, 2011, p.116), provocando o atrofiamento da capacidade de síntese musical, da percepção da música enquanto elaboração estética para a reflexão. A música passa a ser despida das condições para a sua autonomia perante o todo social, passa a ser uma música consumida e compensatória com vestes ilusórias daquilo que se pretende ou se lança ser (seja qual for o sentido destinado a ela: seja o do entorpecimento, o da diversão, o do lazer ou mesmo o da música engajada); que pela repetição do sempre igual sob as vestes do novo e das improvisações, “a função da música se reduz a criar a ilusão [...] de que algo ocorre e se transforma. Sua ideologia é, no sentido mais literal do termo, o et aliquid fieri videator" (ADORNO, 2011, p.129), do latim, para que vejam que algo está sendo 
feito. Que no caso da música engajada, das intervenções artísticas musicais e das práticas educativas que visam ao enfrentamento da situação social tal como se encontra por meio de um processo de identificação estética, de socialização e de profissionalização. E por mais que isso represente um força que resista à homogeneização heterônima, ao cansaço e ao desânimo diários do ritmo cotidiano do trabalho, da carência afetiva, dos preconceitos, do autoritarismo e da exclusão social, esse tipo de práxis musical repete a racionalidade administrativa, a lógica da função musical ideológica e da escuta determinada que, semelhante ao papel do descanso e do lazer, responde aos domínios operantes do trabalho racionalizado ao invés de superá-los. Que, desse modo, segundo Adorno:

Eles não se livram daquilo que esperam fugir. O tempo livre consagrado à soneca esgota-se na mera reprodução da força de trabalho que lança sua sombra sobre tal tempo. Pode-se entrever na música consumida o fato de que nenhum caminho conduz para além da imanência total da sociedade. [...] A atual função da música se insere nessa tendência: ela adestra o inconsciente com vistas aos reflexos condicionados (ADORNO, 2011, p.134, 135).

A arte engajada apresenta conteúdos conscientes se comparada à cultura do entretenimento e à estética do gosto, enquanto estas se encontram totalmente sob os desígnios da indústria cultural, a qual caracteriza-se pela sua irracionalidade, por uma relação destituída de experiência e sentido estético (e, sendo assim, destituída da própria relação qualitativa entre sujeito e objeto), por uma receptividade atomizada e pela atribuição de uma função entorpecente e compensatória de diversão sensorial (ADORNO, 2011; ADORNO; HORKHEIMER, 2006). A arte engajada ainda apresenta um caráter de crítica social contundente, porém como função social determinada anteriormente à própria obra ou intervenção artística (ADORNO, 1993), e que, com vistas de uma transformação social para a democracia e para a cidadania, os conteúdos de crítica social ou de afirmação cultural (no caso, de uma identidade de "ser da periferia") se sobrepõem à espontaneidade e aos próprios conteúdos de verdade da arte. Ao estabelecer esta função sobre a arte, ao tornar certa a sua potencialidade para a crítica social, a relação conjunta e compromissada com a lei formal da arte fica aquém, sem haver a mesma preocupação com a "consideração pela sua formação em si” (ADORNO, 1993, p.277), com a sua essência, o que compromete, consequentemente, o próprio conteúdo de verdade, uma vez que, enquanto sentido convergente 
ao termo de engagement, "[...] apenas se inflamam na nostalgia e na vontade de haver uma mudança" (ADORNO, 1993, p.276).

Ao antecipar o caráter de crítica social da arte de forma dissociada de sentido consciente da sua elaboração estética autônoma, as condições objetivas do em-si da arte são deslocadas. O que evidencia uma comunicação solapada entre os sujeitos organizadores desse tipo de práxis e a própria arte, que se dá, possivelmente, em decorrência da ausência de conhecimentos teóricosformais apropriados e fundamentados, bem como de recursos para a apropriação reflexiva dos mesmos, necessários para evitar recair a uma práxis arbitrária ou ilusória quanto ao seu real alcance social.

Pode-se pressupor que o termo engagement, por mais que se lance a uma disposição de enfrentamento e crítica social, contém elementos de uma consciência esclarecedora transitória, por assim dizer: apresenta uma consciência quanto aos aspectos sociológicos componentes da dominação social, porém, de modo ainda superficial, pois desconhece os aspectos psicológicos subjacentes e imanentes à própria práxis, ou melhor dizendo, as condições subjetivas da irracionalidade objetiva (ADORNO, 2004), o que exige uma relação profunda, comprometida e crítica com o conhecimento teórico para superá-las em sua práxis e nas relações estabelecidas com o mundo à sua volta de forma a ser de fato possível a oposição singular da arte, da cultura e da educação sobre o todo social, ou seja, pela sua autonomia e não pela intenção nomeada do engagement.

No caso da arte e da cultura engajada, pôde-se observar que esta opera de acordo com o esclarecimento positivista, tal como esse, os conceitos de arte e de cultura comportam um sentido a-histórico e fechados em si, ou seja, uma verdade neutralizada e fixada, cuja autonomia e potencialidade política de negação e de recusa social são carimbadas como elementos constitutivos e característicos dados como certos independentemente da consideração quanto às tendências sociais operantes (ADORNO; HORKHEIMER, 2006). Pelo tipo de relação estabelecida com esses campos de saber, tanto eles como seus conceitos são reificados. O que significa a manutenção oculta da racionalidade técnica e administrativa em sua práxis sob o discurso de enfrentamento social e desenvolvimento humano e, por sua vez, revela o seu caráter antagônico e a sua incompatibilidade: o discurso institucional dessas organizações sociais expressa sua intenção social e política de emancipação dos sujeitos e do reconhecimento social do seu repertório cultural, no sentido de uma estética e uma cultura que se oponham e que sejam 
respeitadas, em suas particularidades, frente à dominação social e ao monopólio cultural burguês, ao mesmo tempo que reproduz em sua práxis o mesmo dinamismo da cultura administrada. De acordo com Adorno:

El proceso de neutralización, la metamorfosis de la cultura de cosas en algo autónomo y enajenado de la relación con la praxis posible, permite adaptarla sin contradicciones ni peligros al mecanismo del que se limpia incansablemente. En el hecho de que hoy instituciones oficiales puedan fomentar y representar manifestaciones artísticas extremas, incluso que tengan que hacerlo para que sean en general producidas y lleguen al público, mientras que éstas denuncian, no obstante, lo institucional, lo oficial, puede entenderse algo de la neutralización de lo cultural, así como de la compatibilidad de lo neutralizado con la administración. En la medida en que él mismo en un momento del mecanismo; lo que en ello resulta inutilidad desafiante se convierte en nulidad tolerada o incluso en utilidad mala, en aceite de engrase, en algo que es por otro, en falsedad, en las mercancías de la industria cultural calculadas para los clientes. Esto se clasifica hoy como malestar en la relación entre cultura y administración (ADORNO, 2004, p.124)

Se ausente da disposição para uma análise racional da situação vigente, a práxis educativa e interventiva relativa passa a orbitar no campo de uma razão prática e ideológica, deixando-se escapar à consciência o conhecimento objetivo referente às limitações do alcance da arte engajada, para o qual se requer, antes, disposição para o exercício da autocrítica. No caso específico da identidade periférica aliada à arte engajada, pode se cair no risco de o repertório estético e cultural das periferias ser transformado em produtos culturais com a aparência ilusória de sentido reflexivo crítico, de modo a se justapor os anseios e objetivos de luta e transformação social sobre a real efetivação desta última, regredindo-a.

A relação estabelecida com a arte pelo intermédio da função social como função de necessidade se caracteriza pela não relação, ou seja, pela instrumentalização da arte - “O que as obras foram em si, isso se torna para si” (ADORNO, 1993, p.276) -, o que evidencia, por seu turno, a carência de conceito e de teoria, visto que se perde de vista a consciência reflexiva quanto às próprias disposições imanentes à arte autônoma, dentre elas, a sua liberdade. Para Adorno:

Esta questão está mal posta, porque necessidade da arte, se isso deve, no fim das contas, concernir totalmente à questão do reino da liberdade, é a sua nãonecessidade. Avaliar a arte em função da necessidade é prolongar 
implicitamente o princípio de troca, a preocupação filistina pelo que irá receber em retorno (ADORNO, 1993, p.281).

O caráter de negatividade da arte, por sua vez, não vem a se tratar necessariamente de uma espécie de pessimismo cultural, mas sim de uma denuncia sobre aquilo "[...] que foi recalcado pela cultura estabelecida" (ADORNO, 1993, p.30) e, portanto, consiste em crítica social como consciência da infelicidade, mas de modo que, diferentemente do engagement, "a crítica social deve ser erigida de forma a diminuir todo o conteúdo social manifesto" (ADORNO, 1993, p.280). O imediatismo da arte engajada, com a preocupação para o reconhecimento de fácil entendimento (por vezes, didático) da crítica inerente à sua manifestação estética, "exterioriza-se o processo de fabricação, como muitas vezes na arte, em virtude de uma disposição crescente, se exterioriza um elemento reservado" (ADORNO, 1993, p.276). O que evidencia a determinação de um caráter anti-ilusório e que, em contrapartida, tal como Adorno assinala criticamente sobre as peças de Brecht, contribui "para a decomposição da unidade de coerência do sentido" (ADORNO, 1993, p.276), visto que para a exteriorização visada de determinados conteúdos, a intenção subjetiva e a ideia de verdade do sujeito (o conceito de esclarecimento adotado por ele) se antepõem ao próprio conteúdo de verdade do objeto e, para isso, implica no empobrecimento quanto à sua elaboração estética, ou seja, da consistência estrutural para se exteriorizar a sua interioridade.

A arte autônoma possui a potencialidade de engagement, porém, diferente deste, não como caráter fixo e garantido, ou seja, não enquanto uma função social prevista e exteriorizada, pois esta leva a seu rebaixamento ao status de uma arte aparente. A arte engajada, portanto, com o intuito subjetivo de transformação social que a reveste e a orienta, corre o risco de ser uma promessa falsa para o novo mas que se mantém na antiga estrutura da cultura fetichizada e administrada; e que, com vistas para a mudança através da crítica social e da formação da consciência crítica, esta última pode se reduzir à ilusão de uma quando na verdade o que se atingiu foi a comunicação de massas com aparência de uma consciência pública (ADORNO; HORKHEIMER, 2006), evidenciando-se, por sua vez, uma relação com a arte mediada pelo anteparo de uma consciência ideológica sobre a sua potencialidade estética político social. Para Adorno: 
La negación del concepto de lo cultural mismo se prepara. Sus constituyentes: conceptos como autonomía, espontaneidad, crítica, se cancelan. Autonomía: porque el sujeto, en lugar de decidirse de forma consciente, tiene y quiere insertarse en lo previamente determinado en cada caso; porque el espíritu, que de acuerdo con el concepto tradicional de cultura debe darse a sí mismo la ley, experimenta en cada momento su impotencia frente a las exigencias desbordantes de lo que se limita a ser. La espontaneidad disminuye: porque la planificación del todo es superior a la emoción individual, la predetermina, la reduce a apariencia y no tolera ya ese juego de fuerzas del que se espera el todo libre. La crítica muere por último, porque el espíritu crítico molesta como arena en la máquina en ese proceso que ofrece cada vez más el modelo de lo cultural. Este espíritu aparece como anticuado, armchair thinking, irresponsable y no recuperable. La relación generacional se torna grotesca; la juventud recurre al principio de realidad, la vejez se entrega al vicio de los mundos inteligibles. Los nacionalsocialistas, que anticiparon todo esto violentamente y lo pusieron con ello en ridículo de forma paródica, fueron precisamente, frente a la categoría de lo crítico, mensajeros de un desarrollo en ciernes, al sustituir la crítica por su consideración del arte, en realidad por información sobre lo fáctico, en la medida en que esta información suprime cada vez más el espíritu crítico: ya una serie de publicaciones del todo vanguardistas llevan orgullosas el subtítulo de Información (ADORNO, 2004, p.129).

Apesar de tensionar os moldes da consciência reificada, a exteriorização direta desses conteúdos críticos (por meio de uma estética que aparenta de imediato a consciência quanto à realidade sobre a qual se enuncia), contudo, reduz a possibilidade de relação entre o sujeitoespectador e a obra artística e, consequentemente, a possibilidade para a experiência estética e para a reflexão crítica. Reproduz, assim, elementos proponentes da semicultura e converte-se também em uma força produtiva social, evidenciando-se, portanto, a sua ambivalência. Que, para Adorno:

Nenhuma obra de arte, porém, pode socialmente ser verdadeira se não for também verdadeira em si mesma; inversamente, a consciência socialmente falsa também não pode tornar-se algo de esteticamente autêntico. O aspecto social e imanente das obras de arte não coincidem, mas também não divergem tão completamente como desejariam o feiticismo cultural e o praticismo. Aquilo mediante o qual o conteúdo de verdade das obras, em virtude da sua complexidade estética, vai além desta, possui sempre um valor de posição social. Semelhante ambigüidade não é uma cláusula geral à qual a esfera da arte estaria abstracta e totalmente submetida. Ela é impressa em cada obra, o elemento vital da arte. Torna-se um elemento social mediante o seu em-si e torna-se um em-si pela força produtiva social nela actuante. A dialéctica do elemento social e do em-si das obras de arte é uma dialéctica da sua própria natureza, na medida em que não toleram nenhum elemento interior que se não exteriorize, e nenhum elemento exterior que não seja portador da sua interioridade - do conteúdo de verdade (ADORNO, 1993, p.277). 
Uma obra estruturalmente elaborada se caracteriza por uma cadência harmoniosa de sentido entre suas partes e o todo, em toda a execução de sua obra, um enredo estético estruturado para o envolvimento reflexivo do espectador. O fenômeno da arte se dá em uma obra quando esta guarda em-si uma “[...] objetividade própria, a sua coerência, o seu nível formal, os seus impulsos críticos e, finalmente, a sua idéia de verdade" (ADORNO, 1993, p.18), de maneira a exigir na relação com seu espectador o envolvimento pela espontaneidade, pela imaginação, pela experiência estética e pelo pensamento sensível para que este entre em contato com os conteúdos de verdade da obra, de modo que a interioridade objetiva da obra se exteriorize à consciência pensante do sujeito. Entretanto, no contexto da sociedade vigente, segundo Adorno:

Quanto mais elaborado o produto cultural, menor sua aceitação pela população envolta e ideologicamente estrangulada pelos modos de produção capitalista, de modo que, sendo menos procurados, tais objetos, vistos como produtos especializados, acabam por ocasionar incômoda fissura entre sua essência e sua própria condição de objeto. Em uma sociedade com predominância do fast food, o tempo dessas elaborações encontra-se essencialmente deslocado, imbuindo tais produtos de caráter excêntrico, disforme e não condizente com as necessidades triviais do consumo imediato, distanciando-se da superficialidade dos bens de consumo de massa (ADORNO, 2011, p.17).

A modernidade e o progresso técnico das formas de socialização propostas pelo capitalismo tardio se impõem sobre a própria vida humana criativa, mascarando os mecanismos de sua ideologia dominante pela fachada ilusória e idealizada do livre-arbítrio e da sua constituição individual a partir não mais da sua autonomia e das capacidades reflexivas e críticas, mas pela promessa da riqueza e pela propriedade privada (ADORNO; HORKHEIMER, 1973). À vista disso, esse progresso é o econômico e não o progresso da emancipação e, deste modo, não significam dispor de condições para concepções críticas mais argutas e manifestações estéticas mais elevadas em sua capacidade de experiência e de crítica social de modo a respeitar a sua espontaneidade, o tempo reflexivo e a primazia do seu em-si, pelo contrário, expõem sobre a ideologia dominante e os mecanismos da indústria cultural, antecipada e prevista pelas pesquisas de mercado, sobre o caráter criativo autônomo da obra de arte e sobre o processo de individuação. $\mathrm{Na}$ arte engajada, a sua intencionalidade prevista contraria as possibilidades reais para a liberdade da obra e para a formação cultural, cuja determinação antecipada impede a 
relação criativa entre sujeito e objeto e, consequentemente, para a experiência estética e, tal qual a dominação social, o seu sentido político de engajamento totaliza-se sobre as particularidades tanto do sujeito, como do objeto. Revelando-se, pois, uma relação pouco consciente e crítica com a arte, uma vez que, conforme Adorno (1993):

Ignora a dialéctica da qualidade estética e da sociedade funcional. $\mathrm{O}$ acento põese a priori, se não no efeito ideológico, pelo menos no caracter consumível da arte, e é dispensado de tudo aquilo em que a reflexão social da arte poderia hoje ter o seu objecto: é decidido de antemão de um modo conformista (ADORNO, 1993, p.280).

Como resultado disso, a estruturação consciente e consistente do material estético torna-se passível às leis gerais da tendência e da padronização em detrimento do seu caráter específico do não-idêntico (ADORNO, 1993), significando, dessarte, a regressão da formação cultural em semicultura: a subtração das capacidades necessárias para a experiência estética e para a consciência sensível. No caso da música popular, ao invés de estabelecer com o ouvinte uma relação de escuta pensante, promove o imediatismo do consumo por meio da diversão ou do engajamento social, do falso êxtase pela capacidade de reconhecimento (tido ilusoriamente como o mesmo que a capacidade de compreensão) e pela identificação do sempre igual - sendo que, na verdade, "a embriaguez programada e administrada deixa de ser embriaguez" (ADORNO, 2011, p.91) - e, deste modo, sentir-se pertencente ao todo estéril de sentido ou ao intento da função social da arte engajada: o (pseudo)prazer-alívio da adaptabilidade, condição-trunfo do capital, em que o hit vem a responder às demandas do apelo comercial para o seu consumo e identificação. E os hábitos de audição, por sua vez, não fogem a esse campo de relações de poder, de interesses mercantis, à ossatura de seus artifícios técnicos (a generalização, a padronização, a tendência, a identificação, etc.), bem como à própria relação ideológica. Para Adorno, em seu texto Música popular:

Os padrões musicais da música popular foram originalmente desenvolvidos num processo competitivo. Quando uma determinada canção alcançava um grande sucesso, centenas de outras apareciam, imitando aquela que obtivera êxito. Os hits de maior sucesso, tipos e "proporções" entre elementos eram imitados, tendo o processo culminado na cristalização de standards. [...] eles foram controlados por agências cartelizadas, resultado final de um processo competitivo, e rigidamente imposto sobre o material a ser promovido. $\mathrm{O}$ nãoseguir as regras do jogo tornou-se critério para a exclusão. [...] A concentração 
econômica em larga escala institucionalizou a estandardização, tornando-a imperativa (ADORNO, 1986, p.121, 122).

A liberdade de expressões estéticas diversas mais configuram os termos quantitativos (e, portanto, genérico) a que a qualidade do material estético, pois para a sua elaboração, é imprescindível a diferenciação, a liberdade e a humanidade viva e criativa, como também, conhecimentos formais, experiência estética e a consciência estrutural da lógica estética. Porém, ao invés de uma estética subversiva, antítese do todo social - ao atrelar a ideia sobre esse caráter expressivo a uma identidade cultural e ao tomá-lo como certo pela garantia de sua acessibilidade e produção ampliada, ou melhor dizendo, massificada -, na verdade, está a contrariá-lo, ao adotar a mesma estrutura da cultura administrada e da razão dominante. Conforme a análise de Adorno:

Tornou-se manifesto que tudo o que diz respeito à arte deixou de ser evidente, tanto em si mesma como na sua relação ao todo, e até mesmo o seu direito à existência. A perda do que se poderia fazer de modo não refletido ou sem problemas não é compensada pela infinidade manifesta do que se tornou possível e que se propõe à reflexão. $\mathrm{O}$ alargamento das possibilidades revela-se em muitas dimensões como estreitamento (ADORNO, 1993, p.11)

Arfantes pela esperança do reconhecimento e respeito social, pela real integração, inclusão social e cidadania, ou então daquilo que vem a ser nomeado como "outro generalizado" por Honneth (2003), podem recair em um pragmatismo alienado e nas tramas de exploração da indústria cultural, que deslumbra pela falsa promessa de pertença, de status e de estima social por meio da ostentação do consumo, iludindo-os, como a todos, quanto ao processo de identificação e de formação identitária dentro do campo fenomenológico da arte engajada, atenuando a sua potencialidade política, sobrelevando-se e agregando à sua produção artística e cultural um função (social) programada e um valor de troca, incutindo sem se perceber o caráter de fetiche: uma relação aparente com a arte. Ilustra-se, assim, alguns elementos da própria semicultura e de seu alcance subjetivo, o qual "não se confina meramente ao espírito, adultera também a vida sensorial. E coloca a questão psicodinâmica de como pode o sujeito resistir a uma racionalidade que, na verdade, é em si mesma irracional" (ADORNO, 2005, p.11).

Em uma perspectiva dialética, é ilusório pressupor a oposição aos conteúdos de desassossego e da desumanização social pela arte e pela cultura sem a condição da experiência intelectual e sem a consciência quanto à dialética entre autonomia e dominação que medeia a 
formação cultural, cabendo compreendê-las também enquanto "unidade dos contrários, mercado e autonomia” (ADORNO; HORKHEIMER, 2006, p.130) dentro da sua própria interioridade fenomenológica e estética. O valor de uso pragmático da arte e da cultura enquanto uma função programada para a crítica social ou para uma estética identitária afirmativa não é efetivo pelo combate direto da ordem econômica-social e pela exteriorização imediata de seus conteúdos, de modo que, conforme Adorno:

Enquanto o pensamento se restringe à razão subjetiva, suscetível de aplicação prática, o outro, aquilo que lhe escapa, vem a ser correlativamente remetido a uma práxis cada vez mais vazia de conceito, e que não conhece outra medida que não ela própria (ADORNO, 1995, p.204).

Que deste modo, tal como afirmam Adorno e Horkheimer:

Os que sucubem à ideologia são exatamente os que ocultam a contradição, em vez de acolhê-la na consciência de sua própria produção, como Beethoven. Este exprimiu musicalmente a cólera pelo vintém perdido e derivou das reclamações da senhoria a exigir o pagamento do aluguel aquele metafísico "Es Muss Sein" ["Tem que ser"], que tenta superar esteticamente as limitações impostas pelo mundo. (ADORNO; HORKHEIMER, 2006, p. 130)

A suposta resistência nas estéticas musicais específicas do funk e do rap, quando ausentes de autocrítica, acabam por ser "[...] uma tentativa condenada ao fracasso" (ADORNO, 2005, p.8). O mesmo pode acontecer com a luta por reconhecimento dos movimentos e coletivos artísticos e culturais das periferias, e a educação musical propiciada por diversos outros projetos socioeducativos instalados nesses territórios. No afã de sua luta, de sua resistência, de sua existência singular, inebria-se e cai trôpega, idealizada, cuja atitude estética, distanciada da relação entre teoria e práxis, acaba por recair, na verdade, à “[...] formação cultural objetivamente arruinada" (ADORNO, 2005, p.8). Na sociedade do capital, conforme Adorno:

[...] a totalitária figura da semiformação não pode explicar-se simplesmente a partir do dado social e psicologicamente, mas inclui algo potencialmente positivo: que o estado de consciência, postulado em outro tempo na sociedade burguesa, remeta, por antecipação, à possibilidade de uma autonomia real da própria vida de cada um - possibilidade que tal implantação rechaçou e que se leva a empurrões como mera ideologia. Porém, aquela identificação tende a fracassar, porque o ser singular nada recebe em relação a formas e estruturas de uma sociedade virtualmente desqualificada pela onipotência do princípio de 
troca - nada com o qual, sob certa proteção, pudesse identificar-se de alguma forma, nada sobre o qual pudesse formar-se em sua razão propriamente dita. Por outro lado, o poder da totalidade sobre o indivíduo prosperou com tal desproporção que tem que reproduzir em si esse vazio de forma. O que antes estava de tal modo configurado que os sujeitos podiam conseguir aí sua imagem, problemática, que fosse - tem essa origem; porém eles estão tão destituídos de liberdade que sua vida conjunta não se articula como verdadeira, pois lhe falta $o$ necessário apoio em si mesmos (ADORNO, 2005, p.8).

A identidade carrega em si, por sua vez, um caráter problemático, quando há desigualdade de forças entre o todo coletivo e o indivíduo: o do monopólio, o da generalização, o da padronização e da limitação determinada da própria autonomia e liberdade requeridas, colocando em segundo plano, ou até mesmo recaindo ao esquecimento, a consciência e o reconhecimento quanto à diversidade de modos de existência de cada indivíduo que compõe um grupo identitário, contrapondo-se e fazendo minguar, possivelmente, as condições reais para a diferenciação e para a emancipação dentro de um contexto comunitário ou grupal e, assim sendo, para o desenvolvimento e expressão da singularidade de seus sujeitos e, por conseguinte, para a arte autônoma e para a formação cultural. Não à toa, para Adorno (2005), a identificação é o próprio espírito da indústria cultural, sendo ela a própria semicultura, em que "a indústria cultural realizou maldosamente o homem como ser genérico" (ADORNO; HORKHEIMER, 2006, p.120). Para Adorno e Horkheimer:

A unidade evidente do macrocosmo e do microcosmo demonstra para os homens o modelo de sua cultura: a falsa identidade do universal e do particular. Sob o poder do monopólio, toda cultura de massas é idêntica, e seu esqueleto, a ossatura conceitual fabricada por aquele, começa a se delinear (ADORNO; HORKHEIMER, 2006, p.100).

As formações grupais se constroem por meio de um encapsulamento identitário e que se fortalecem e se legitimam pelas sensações de satisfatoriedade, segurança e encorajamento despertadas a partir da vivência de fazer parte de uma coletividade que possui um mesmo intento - pois, querendo ou não, diante do enfraquecimento, opressão e angústia das pessoas oprimidas e impotentes diante da dominação social, estas (nós) "sentem-se fortes quando andam de mãos dadas" (ADORNO, 1995, p.226) -, e apresentam elementos de uma atividade política de ressignificação das normas sociais, ampliando-as quanto à inclusão do respeito à diversidade de modos de ser. Entretanto, por outro lado, a tônica dada ao processo de socialização identitária dá 
margem para se passar batido a própria individuação dentro desses grupos, podendo-se deixar escapar à consciência quanto à possibilidade de um processo contrário ao da autonomia: a renúncia da própria possibilidade de individualidade e, assim sendo, da própria razão e do próprio juízo (ADORNO, 1993). Ao ser reconhecidas como pessoas melhores na medida em que reconhecem a sua boa vontade de integração e representação à totalidade dos elementos que constituem essa identidade, pelo ajustamento social dentro desse núcleo grupal, “eles se tornam partícipes de uma razão superior, coletiva; para conhecer a verdade, pelo contrário, seria imprescindível aquela razão incondicionalmente individuada" (ADORNO, 1995, p.226), da experiência de um Eu que possa continuar a existir seguramente mesmo se se opor à essa coletividade. Diante disso, podemos afirmar que a noção conceitual de identidade em qualquer contexto que seja é delicada e vem a ser uma ferramenta de socialização paradoxal no campo de socialização da luta social e da arte engajada, pois contraria a própria emancipação.

O processo de identificação pode comportar uma totalidade totalitária e, consequentemente, massificante. No âmbito da socialização como elemento inerente para a formação e para a individuação, isso significa um prolongamento do processo contrário ao da formação cultural e da transformação social, a regressão do esclarecimento à ideologia e a conversão da estética reflexiva crítica em produto cultural identitário. Enquanto unidade do todo social, essa dinâmica expressa as relações sociais nas quais "a perene sociedade do status absorve os restos da formação e os transforma em símbolos daquele" (ADORNO, 2005, p.11), de seu sucedâneo, a semiformação.

Outro aspecto a se problematizar sobre o processo de formação identitária da cultura periférica por meio da arte engajada é o de que, para além do reconhecimento social e, por assim dizer, da legitimação do seu repertório cultural, a identidade de "ser periférico", hoje, também foi transformada em valor agregado, o que evidencia aspectos de valor de uso e de valor de troca, a arte enquanto engagement e, vinculado a esse teor que passa a ser também estratégia publicitária, mercadoria. Segundo Tommasi:

[...] é através do acionamento identitário que opera essa disputa. A inclusão (no e pelo mercado da arte) ocorre através da expressão da alteridade, territorial e política. Ou seja, os artistas periféricos fazem da sua localização periférica o valor agregado vendável no mercado, que, por sua vez, estava politicamente disponível a valorizar a produção periférica, tanto do ponto de vista da busca, sempre presente no mercado da arte, pela inovação, como do ponto de vista da 
descoberta-afirmação, toda política, de um lado "bom" da periferia (TOMMASI, 2013, p.26).

Isso evidencia a inescapável influência da indústria cultural e o rebote da desigualdade social na práxis política cultural. Ao mesmo tempo que há um esforço para uma estética crítica, a sua visibilidade social é apropriada e expropriada pelo avidez do mercado, cujo poder dominante limita a rebeldia, a revolução, a fúria e a objetividade das resistências propostas pelas próprias condições de opressão e exclusão que ela determina, contra as quais essas forças reagem e frente as quais simultaneamente se submetem. O que se apresenta como potencialidade cultural e estética crítica pela sua capacidade de burlar os mecanismos de censura (ADORNO; HORKHEIMER, 2006) torna-se muitas vezes um empreendimento sociocultural que, por sua vez, com fins de resolver problemas sociais, o faz por meio da instrumentalização da arte e de um novo arranjo de estereótipos, mas dessa vez, embasado por uma perspectiva unilateral positiva. Desse modo, mais uma vez, a fome do pão e o anseio por conquistar um lugar ao sol afligem a própria vida sensível e as contingências para uma transformação social efetiva e humana, pois abdica-se da própria autonomia, ou melhor, das condições para a apropriação subjetiva da cultura, a formação cultural. Tal como afirmam Adorno e Horkheimer:

O simples fato de continuar a existir e continuar a operar converte-se em justaposição da permanência cega do sistema e, até mesmo, de sua imutabilidade. $\mathrm{O}$ que é salutar é o que se repete, como os processos cíclicos da natureza e da indústria. Eternamente sorriem os mesmos bebês nas revistas, eternamente ecoa o estrondo da máquina de jazz. Apesar de todo o progresso da técnica de representação, das regras e das especialidades, apesar de toda a atividade trepidante, o pão com que a indústria cultural alimenta os homens continua a ser a pedra da estereotipia (ADORNO; HORKHEIMER, 2006, p.122, 123).

Sob as particularidades que compõem a identidade de "ser periférico", pode-se encobrir o totalitarismo da dominação, do qual não podem escapar, de modo que o "individual reduz-se à capacidade do universal de marcar tão integralmente o contingente que ele possa ser conversado como o mesmo" (ADORNO; HORKHEIMER, 2006, p.128).

O acionamento identitário da cultura periférica pode também se expressar contraditoriamente no que diz respeito às próprias relações de socialização idiossincrática com pessoas e grupos oriundos de outros estratos sociais, os "não periféricos", e também com 
espectadores que não compartilham necessariamente do mesmo gosto estético e dos mesmos conteúdos morais, observando-se, assim, seus paradoxos: "os jovens de periferia produzem, através de táticas culturais como o hip hop, uma crítica social poderosa; ao mesmo tempo, estabelecem uma distância não negociável entre pobres e ricos, centro e periferia, brancos e pretos, articulando uma posição de enclave" (ROY, 2011, p. 232 apud TOMMASI, 2013, p.26). Nesses casos, a identidade se torna a replicação do muro da exclusão e da hostilidade ao invés do reconhecimento recíproco que reclamam para si: projeta sobre o outro a manutenção da ordem que busca combater, expondo o outro a algum tipo de repressão coletiva, como efeito de aquele não corresponder às normas inferidas por determinado grupo. Trata-se, porventura, da identidade cultural como uma espécie de "natural particular" (ADORNO; HORKHEIMER, 2006), autoafirmação de uma coletividade fechada. O que dá indícios da manutenção da ordem moral da dominação que atenta contra a autonomia, contradizendo, pois, o próprio engajamento para a democracia.

De todo modo, implícita à ideia de identidade está a padronização, a ênfase aos caracteres genéricos sobre a possibilidade de autonomia e autenticidade do sujeito, - e, portanto, sobre as possibilidades de individuação e desenvolvimento de suas singularidades enquanto indivíduo -, ressaltando conteúdos históricos, políticos e culturais ainda não reconhecidos e integrados pelo macrocosmo social e em suas leis gerais de governança e desenvolvimento social. A identidade da cultura periférica, do "ser da periferia", confronta a estrutura dominante da normatização dos ideais burgueses sobre qualquer outra que se oponha a esta, no entanto, por mais que em torno da identidade orbitem elementos da socialização, tais como o reconhecimento, o sentimento de pertencimento e a auto estima coletiva, é justamente a sua estrutura que vem a ser um dos elementos a comprometer o processo de individualização, o qual só é possível mediante a experiência de emancipação dentro da sua coletividade, ao invés de se limitar ao ajustamento grupal e a uma nova normatização na qual se sintam mais representados e pertencentes.

A identidade é da ordem do predomínio do universal, do reconhecimento e do ajustamento, em agravo à compreensão, ou seja, à capacidade do pensamento e da autoconsciência. A identidade configura-se como substrato da pseudoindividuação: o empobrecimento das experiências, a semicultura e a indústria cultural contribuem para a predominância da totalidade em detrimento do tensionamento entre o universal e o individual, entre o todo e suas partes, fazem prevalecer o fortalecimento de uma consciência ideológica e da 
formação regredida. Diante disso, a transformação social, a cidadania e a crítica estética retornam à mesma subjetividade domesticada, à cultura de massas e à pseudo individuação. Segundo Adorno e Horkheimer:

A pseudoindividualidade é um pressuposto para compreender e tirar da tragédia sua virulência: é só porque os indivíduos não são mais indivíduos, mas sim meras encruzilhadas das tendências do universal, que é possível reintegrá-los totalmente na universalidade. A cultura de massas revela assim o caráter fictício que a forma do indivíduo sempre exibiu na era da burguesia, e seu único erro é vangloriar-se por essa duvidosa harmonia do universal e particular (ADORNO; HORKHEIMER, 2006, p.128).

A integração social por meio da identidade, destacada muitas vezes como algo positivo, corre o eminente risco de ser, na verdade, o aprisionamento do sujeito e o impeditivo do desenvolvimento de suas faculdades psicológicas superiores, por assim dizer, a consciência crítica. Esta, por outro lado, implica a liberdade de oposição e de crítica a seus grupos sociais sem que estes respondam a isso com repressão, violência e exclusão, pois "outrora, a oposição do indivíduo à sociedade era a própria substância da sociedade" (ADORNO; HORKHEIMER, 2006, p.127). Paradoxalmente, no contexto da práxis das organizações sociais envolvidas com a arte engajada, "assim procura subjetivamente a possibilidade de formação cultural, ao mesmo tempo, em que, objetivamente, se coloca todo contra ela" (ADORNO, 2005, p.15).

Se não houver condição e disposição para autocrítica e para autodeterminação, aquilo que intenta à transformação social a partir do reconhecimento mútuo, do respeito à diversidade e da inclusão social por meio da arte e da cultura pode, com efeito contrário, sucumbir à ordem operante do sempre igual da cultura administrada, da mesmice do ideal genérico e heterônimo e, quando em agravos delirantes, pode caminhar para "a despersonalização do mundo" (ADORNO, 2005, p.16). Ou seja, de acordo com Adorno:

Lo que aspira por sí mismo a ser autónomo, crítico, antitético, y lo que no puede desde luego satisfacer nunca del todo esta aspiración, tiene que atrofiarse cuando sus impulsos se insertan dentro de algo heterónomo a ellos, de algo previamente pensado desde arriba; cuando, si es posible, recibe el espacio para respirar de la gracia de eso contra lo que se rebela (ADORNO, 2004, p.125).

O pensamento é um ato de resistência e condição necessária para uma práxis mais elevada (ADORNO, 1995). E pensando na possibilidade de haver um resto de autonomia mesmo sob a 
condição de oprimidos e na possibilidade de superação da barbárie, seguimos a compreensão de Adorno em Educação e emancipação (2006) quanto à real disposição da liberdade intelectual dessas pessoas e, por sua vez, quanto à qualidade objetiva de suas formas de resistências, que assemelham-se ao intento da educação política enquanto educação para a emancipação e, consequentemente, para a democracia concreta. Logo, a necessidade de autoconsciência sobre a própria condição para uma práxis emancipatória implica saber que, de acordo com Adorno (2006):

[...] às vezes me parece que a liberdade já se encontra abalada também naqueles que formalmente ainda a possuem, como se os seus hábitos intelectuais já se identificassem ao que é regressivo, ainda que este não tenha sido prescrito; como se algo nas próprias pessoas esperasse por ser dispensado do peso da autonomia, cujo significado representa tudo o que alguma vez foi valorizado e considerado verdadeiro na Europa. Na incapacidade do pensamento em se impor, já se encontra à espreita o potencial de enquadramento e subordinação a uma autoridade qualquer, do mesmo modo como hoje, concreta e voluntariamente, a gente se curva ao existente. Alguns possivelmente ainda procurarão sacramentar o próprio encantamento como sendo o que o jargão da autenticidade denomina de vínculo autêntico. Enganam-se, porém. Eles não se encontram além do isolamento do espírito autônomo, mas sim aquém da individuação, a qual por isto mesmo não conseguem superar nos termos que imaginavam (ADORNO, 2006, p.71).

Em vista dessa discussão, pode-se afirmar que os passos para a transformação são vagarosos e árduos, seguem a própria história e suas contradições, "que a história é uma senhora lenta, caprichosa, às vezes louca, muito complicada, muito misteriosa. Muito mais misteriosa do que nós cremos que seja. Que não nos dá a mínima bola. Que não nos obedece. Porque o tempo dela é um tempo infinitamente maior que o nosso (GALEANO apud TENDLER, 2009). O tempo dos nossos anseios e esperanças desejosas pelas experiências faltantes de democracia não é o tempo da transformação social objetiva, este é elíptico, tal como é a própria história, a própria sociologia e subjetividade das pessoas; trata-se de um tempo lento e paciente que abarca o tempo da desconstrução da barbárie de cada um, o tempo para a reconstrução de novas normas de socialização que possibilitem o tempo do encontro, da experiência e do pensamento, o tempo da educação formativa e da individuação, trata-se, pois, de um tempo que não corresponde ao dos nossos desesperos e impaciências. Se convencidos e inebriados pela utopia das palavras de ordem e esperança, pela emergência da transformação social, sua práxis poderá convergir em uma 
ingenuidade ideológica que suprime a própria práxis, indisposta à teoria. Pode, à contramão, caminhar para a continuidade da autodestruição do esclarecimento, para a reprodução daquilo que se visa combater (em sua ossatura ideológica), para a desintegração dos sonhos objetivos de justiça, de liberdade e igualdade social, recaindo a uma práxis aparente: que "o agir imediato, no entanto, que sempre lembra o bater com estrondo [Zuschlagen], está incomparavelmente mais próximo da repressão do que o pensamento, o qual o ajuda a respirar” (ADORNO, 1995, p.223).

As organizações sociais em questão e a arte engajada, no contexto social comunitário investigado, apresentam algo que, para Adorno (1995), é essencial para aquilo que ele considerou como "práxis oportuna": o esforço para a superação da barbárie. Sua práxis já se orienta por esse sentido, contudo, cabe ir além: a sua elaboração crítica de modo a superar de fato elementos de sua morada, elementos da dominação social, da razão ideológica imanente, da cultura administrada, da pseudoformação e até mesmo elementos do antissemitismo presentes tanto na esfera do macrocosmo social, como também, no próprio microcosmo coletivo comunitário, organizativo idealizador, das relações interpessoais componentes e, por fim, na própria subjetividade das pessoas envolvidas.

Para a relação com a arte, com a educação e com a cultura, vislumbrando-se a uma verdadeira democracia, deve-se, antes, abrir-se para o reconhecimento e enfrentamento das próprias fraquezas egóicas e grupais, como forma inicial de superá-las e, concomitantemente, chamar a atenção para a necessidade de avaliação crítica quanto à objetividade de sua práxis e quanto à qualidade de seu planejamento político, pedagógico e criativo, e quanto às condições para a relação com a arte autônoma e quanto ao respeito à sua primazia, de modo a, pela autoconsciência sustentada pelo conhecimento teórico, avaliar os substratos subjetivos e ideológicos presentes nos conceitos adotados para a organização da práxis, bem como nas relações interpessoais e intersubjetivas estabelecidas nesses grupos. O que exige, deste modo, disposição, tempo e paciência para se abrir a um doloroso processo para a formação crítica e autocrítica, para a experiência de emancipação, o qual se dará mediante a teoria e, junto com ela, a formação processual de uma consciência que se dá simultânea ao confronto e à superação das próprias forças e necessidades anímicas dos envolvidos nesse tipo de trabalho social que impedem reconhecer as limitações e contradições de sua práxis engajada e, muitas vezes, identitária (ADORNO, 1995). Logo, “a questão é que o esclarecimento tem que tomar consciência de si mesmo, se os homens não devem ser completamente traídos. Não se trata da 
conservação do passado, mas de resgatar a esperança passada" (ADORNO; HORKHEIMER, 2006, p.14). Para que, assim, possa se iniciar um processo de ruptura dos enlaces da dominação social e da barbárie, a começar pela própria reconciliação entre teoria e práxis.

\subsection{Acessibilidade ou democratização da cultura?}

A democratização da arte, da cultura, bem como da educação estética é um dos principais objetivos tanto dos movimentos e coletivos culturais e dos projetos socioculturais no contexto dos territórios de periferia, sendo um dos principais objetivos para o desenvolvimento da escola de música em questão, e que, cada um à sua maneira, busca compensar a frágil atuação pública nessas áreas urbanas. Porém, com base nos dados obtidos na pesquisa bibliográfica, no mapeamento territorial e também na pesquisa empírica, observou-se que a discussão acerca da democratização da cultura e da educação estética é indicada muitas vezes pela totalização de um dos seus aspectos fundamentais, mas não suficiente: o direito universal ao acesso à arte, à cultura e à educação.

O enfoque à acessibilidade aos bens culturais e à educação estética, em detrimento da compreensão das demais esferas que compõem o processo de democratização da cultura e da

formação, é identificado nos diversos cenários da educação mais propriamente. No que toca à educação escolar, por exemplo, essa questão é verificada nas próprias mudanças e progressos legislativos referentes à inclusão obrigatória das linguagens artísticas (dentre elas, a música) no currículo básico das escolas regulares (LDBEN/96; Lei n. 11.769/2008; PNE/2006; PMESP/2015; Lei n. 13.278/2016). Segundo consta em seus conteúdos legislativos, observou-se, em contrapartida, que o objetivo do ensino das diferentes linguagens artísticas nas escolas regulares se encontra pouco estruturado, caracterizado por definições conceituais genéricas, abrangentes e até ambíguas de arte, cultura e educação, como também, por sentidos e finalidades pouco consistentes (FIGUEIREDO, 2005; OSTETTO, 2011; PENNA, 2004, 2008). O que assemelha-se ao uso da linguagem e da palavra com caráter publicitário da cultura, no qual, o conceito esvazia-se do seu conteúdo objetivo (ADORNO; HORKHEIMER, 2006), sendo referido de modo acrítico e arbitrário, o que assinala a ausência de relação e de sujeito. Segundo Adorno e Horkheimer: 
[...] quanto mais completamente a linguagem se absorve na comunicação, quanto mais as palavras se convertem de veículos substanciais do significado em signos destituídos de qualidade, quanto maior a pureza e a transparência com o que transmitem o que se quer dizer, mais impenetráveis elas se tornam (ADORNO; HORKHEIMER, 2006, p.136).

O que gera diferentes possibilidades de interpretações ao invés de uma compreensão refletida e, consequentemente, dá espaço para práticas pedagógicas superficiais e pouco fundamentadas. A inclusão da educação musical nas escolas regulares foi avaliada como sendo um processo problemático e deficiente (FIGUEIREDO, 2005; PENNA, 2004, 2008), apesar de se reconhecer a importância do progresso legislativo favorável à ampliação do acesso a essa área de saber. Ao que se refere à educação musical, especialmente, a adoção predominante de sistemas de ensino-aprendizagem musical subsidiados minimamente por uma fundamentação teóricapedagógica consistente e os casos nos quais não havia sequer um planejamento pedagógico apropriado para o ensino desta modalidade artística foram reconhecidos, tendo-se constatada a prevalência da polivalência e do experimentalismo (PENNA, 2002, 2004, 2008), que requerem pouco conhecimento específico acerca da estética musical e da arte de modo geral. Somado a isso, os educadores responsáveis pelo ensino da música no ensino básico apresentaram, em sua maioria, formação insuficiente (formal e cultural) para a efetivação de qualidade da educação musical (PENNA, 2002; SECRETARIA DE EDUCAÇÃO À DISTÂNCIA, 2010). O que reflete o processo de racionalização irrefletida dos conceitos de arte, cultura e educação que os reduz em seus desígnios nominais tão apenas, em que pelo simples fato de nomeá-los como intenções objetivas no campo formativo é como se isso, por si só, garantisse a objetividade e a consistência de sua práxis, quando, na verdade, se tem uma práxis aparente e, por assim dizer, arte, cultura e educação estética que "[...] nada mais são do que o nome que os designa" (ADORNO; HORKHEIMER, 2006, p.136).

Quanto aos projetos socioculturais das periferias, por sua vez, foi também observado um uso conceitual ingênuo, sem as devidas compreensões sociológicas do momento social quando a arte, cultura e educação são requeridas no sentido da finalidade de sua democratização. Como porta-bandeiras de lutas sociais, a potencialidade política para a crítica social e para a emancipação dos sujeitos por meios desses campos de saber não são verificados reflexivamente e criticamente, mas tidos como fórmulas e promessas invariantes para a formação humana e cultural: "A cegueira e o mutismo dos fatos a que o positivismo reduziu o mundo estendem-se à 
própria linguagem, que se limita ao registro desses dados" (ADORNO; HORKHEIMER, 2006, p.136). O que se exprime pela toada da sua democratização pela acessibilidade, sem haver as considerações necessárias quanto às condições objetivas e sociais tanto para a autonomia da arte, da cultura e da educação, como para a formação de indivíduos autônomos e de uma consciência esclarecida. O que revela a expressão da consciência regredida como resultado das determinações sociais e dos mecanismos ideológicos da indústria cultural na interioridade desses movimentos e dos avanços legislativos em favor da formação cultura e da sua democratização. E que, diante disso, ao invés de contribuir para a formação cultural, podem mais é manter e reforçar, contrariamente, os processos ideológicos operantes da crise social e educacional, mais especificamente, “[...] porque abrandam as necessárias exigências a serem feitas aos que devem ser educados e porque revelam uma inocente despreocupação frente ao poder que a realidade extrapedagógica exerce sobre eles" (ADORNO, 2005, p.2).

Nestes diferentes contextos grupais e institucionais, os trabalhos educativos e socioculturais, como também até as produções musicais, se voltam direta ou indiretamente a benefício da democratização da arte e da cultura, ou da idéia conceitual que se têm sobre essa, por meio de estratégias para a viabilidade do acesso universal em detrimento da real democratização da arte e da cultura que, para tal, só é possível mediante a formação cultural enquanto diferenciação, enquanto capacidade reflexiva e crítica do pensamento autônomo (ADORNO, 2005, 2006; ADORNO; HORKHEIMER, 2006). Sendo necessário, por sua vez, pensar a democratização da arte, cultura e da educação a partir do tipo de relação estabelecida com a cultura, seu sentido e finalidade (ADORNO, 2005), e das condições sociais concretas para o desenvolvimento psicológico apto a fazer experiências e para a apropriação reflexiva dos conteúdos artísticos, para isso, de acordo com Adorno (2005), seria preciso "[...] a partir do movimento social e até mesmo do conceito de formação cultural, buscar como sedimenta [...] uma espécie de espírito objetivo negativo" (ADORNO, 2005, p.2). Sua exigência política é própria da educação e, por conseguinte, de seus espaços formativos.

No que se refere às instituições escolares e às suas medidas legislativas, a democratização da educação musical é mais aparente do que real pela insuficiência de seu planejamento políticopedagógico. A relação entre as normas da legislação educacional, as diretrizes dos parâmetros curriculares nacionais e as práticas institucionais escolares, referentes ao ensino de artes nesse contexto, indica uma negligência do Estado e dos autores desses documentos legislativos e das 
políticas educacionais quanto à concretude da formação cultural dos alunos, bem como dos educadores, uma vez que seus conteúdos parecem partir de um senso comum e pragmático, distanciados do comprometimento com a sua objetividade e, desta forma, do comprometimento com o conhecimento teórico que fundamentaria tal projeto de educação das diferentes modalidades artísticas. O que torna necessário, primeiramente, o questionamento quanto ao verdadeiro compromisso das entidades públicas para com a sociedade civil e, sobretudo, com a própria formação cultural, tal como é problematizado por Penna:

[...] cabe indagar se são realmente de nosso interesse determinações da sociedade política que não tenham condições de ter reflexos efetivos na sociedade civil. Pois, [...] tais determinações podem se tornar letra morta ou mesmo levar à aceitação de práticas que na verdade não contribuem para o reconhecimento do valor da educação musical (PENNA, 2008, p.61).

Quanto ao mapeamento territorial, os sentidos de resistência política, pela luta por reconhecimento e do direito democrático de acesso à arte foram eleitos como força diretiva pelos movimentos e coletivos culturais para o desenvolvimento de seus programas culturais como forma de enfrentar as desigualdades e os privilégios sociais, a que o próprio sentido de arte enquanto "veículo da Ideia" (ADORNO; HORKHEIMER, 2006). A função social determinada e a ênfase que recai sobre o alcance cultural quantitativo revelam elementos da racionalidade administrativa, da heteronomia e do predomínio do caráter genérico sobre qualquer possibilidade de singularidade e autonomia tanto do indivíduo como da obra artística, estreitando, consequentemente, as possibilidades para "a atividade intelectual do espectador" (ADORNO; HORKHEIMER, 2006, p.104), pois sua liberdade e espontaneidade são impedidas, assim como, não se foram pensadas criticamente as condições objetivas e sociais para a relação com os conteúdos culturais disponibilizados pela acessibilidade. Para Adorno e Horkheimer (2006), em relação à ampliação do acesso às obras de arte pelas camadas sociais economicamente mais desfavorecidas, esta representa a simulação da ampliação da igualdade de direitos, mas, na verdade, tal como se dá, calcifica qualquer possibilidade para a experiência formativa intelectual e sensível, reforçando o estado do espírito alienado. Mas que pela intenção subjetiva à democratização da formação cultural, isso vem a lubridiar ainda mais a consciência quanto à reificação humana, cujo processo de acessibilidade aparenta o alcance quantitativo da formação 
cultural, quando na verdade, mantém-se a semiformação socializada (ADORNO, 2005). Para esses autores:

A eliminação do privilégio da cultura pela venda em liquidação dos bens culturais não introduz as massas nas áreas de que eram antes excluídas, mas serve, ao contrário, nas condições sociais existentes, justamente, para a decadência da cultura e para o progresso da incoerência bárbara (ADORNO; HORKHEIMER, 2006, p.132).

Por mais que esses movimentos e coletivos, e também os projeto socioculturais, não se organizem pelos esquematismos com fins de entretenimento e do consumo, como faz a cultura de massas de modo geral engendrada pela indústria cultural, a sua função política acaba por recair, quando em seus possíveis desvarios irrefletidos, em uma arte administrada, em que acaba por se realizar, na verdade, "aquele idealismo sonhador que ia longe demais para o idealismo crítico" (ADORNO; HORKHEIMER, 2006, p.103) e, por assim dizer, irreal.

De modo contrário, bastar-se à acessibilidade como esta fosse a totalidade da democratização da cultura significa sobrepor o fator de quantidade estatística sobre o de qualidade objetiva da formação cultural e, assim sendo, significa acomodar-se a um estado compensatório e enganoso quanto à própria falta daquela (ADORNO, 2004). Tal como é evidenciado, mais especificamente, na relação com a música e na aparente democratização da cultura musical, sem se levar em conta as condições para a experiência estética e para um tipo de comportamento musical que comporte relações espontâneas e a capacidade para se formar juízos bem fundamentados (ADORNO, 2011), que, tal como na ascensão na racionalidade técnica, a publicidade valorativa dos mecanismos de produção de massa fez-se acreditar ser condição suficiente para a democratização da cultura. Segundo foi apontado por Adorno em seu texto Tipos de comportamento musical:

Assevera-se, por exemplo, que os meios de produção mecânicos e de massa teriam, pela primeira vez, levado a música a um número incontável de indivíduos e que, por isso, conforme os conceitos de generalidade estatística, o nível de escuta teria elevado-se (ADORNO, 2011, p.56)

Como se pode constatar, a lógica que combate o elitismo cultural assemelha-se à lógica da sua produção e os seus fins, aos da cultura de massas e à limitada caridade burguesa, uma vez que 
mais parece se orientar pelo intento de uma noção empirista a-histórica e, logo, ideológica administrativa. Trata-se, pois, de um sério autoengano o planejamento de uma práxis que considera cumprir a garantia igualitária de direitos, de prover condições para que todos passem a ter acesso aos bens culturais sem considerar a formação cultural e, sendo assim, sem considerar e evidenciar os próprios indivíduos e a sua formação no sentido de uma consciência esclarecida. Isto porque as medidas tomadas continuam ser exteriores aos indivíduos público alvo de sua ação. De modo contrário, para Adorno:

A formação tem como condições a autonomia e a liberdade. No entanto, remete sempre a estruturas pré-colocadas a cada indivíduo em sentido heteronômico e em relação às quais deve submeter-se para formar-se. Daí que, no momento mesmo em que ocorre a formação, ela já deixa de existir. Em sua origem está já, teleologicamente, seu decair (ADORNO, 2005, p.9).

Não se pode pensar em democracia sem a emancipação de seus sujeitos, sem indivíduos singulares, e nem em formação cultural sem a apropriação subjetiva reflexiva da cultura (ADORNO, 2005, 2006). Para a qual a relação imediata com a cultura não é condição suficiente, quando, na verdade, pode levar a sua conversão em uma mera relação de consumo e à manutenção da consciência alienada, já que a racionalidade e a sua psicologia imanente permanecem intocadas. De acordo com Adorno:

La política cultural que no es socialmente ingenua ha de analizar esta cuestión sin miedo a la amonestación de las mayorías. Cierto que la contradicción entre el orden democrático y la conciencia de hecho de los que a través de las relaciones siguen retenidos en la minoría de edad no puede eliminarse mediante una simple política cultural. Pero la democracia representativa, a la que a la postre deben también su legitimación los expertos en la administración de asuntos culturales, tolera una cierta compensación; permite impedir maniobras que sirven a la barbarie, corrompiendo la idea de la cualidad objetiva mediante la apelación taimada de a la volonté de tous. A la política cultural hay que aplicarle la reflexión de Benjamin sobre el crítico que ha de representar los intereses del público contra el público (ADORNO, 2004, p.134, 135).

A democracia real continuaria inexistente mesmo com a acessibilidade garantida àqueles antes excluídos dessa possibilidade se assim mantiver o poder totalitário, a adaptabilidade e coerção social, a identificação normativa e a situação de não-emancipação. O mesmo se passa com a ideia propositiva da "educação popular" destinada ao proletariado, que, de acordo com 
Adorno (2005), frente à estrutura de poder desumana instituída pelo capitalismo, na qual foi negada aos trabalhadores as condições essenciais para a formação e para o ócio, "as tentativas pedagógicas de remediar a situação transformaram em caricaturas” (p.5), cujo intento educativo “[...] nutriu-se da ilusão de que a formação, por si mesma e isolada, poderia revogar a exclusão do proletariado, que sabemos ser uma realidade socialmente constituída" (p.5). Ou seja, a democracia só é possível na "produção de uma consciência verdadeira" (ADORNO, 2006, p.141), cabendo, pois, à educação este papel político cultural, o de propiciar o desenvolvimento processual da autonomia e da liberdade, da aptidão à experiência, o envolvimento e a relação direta entre sujeito e objeto, bem como a instigação esforçosa do pensamento. Ademais, ao que diz respeito à democratização da cultura, se esta é tomada pela sua acessibilidade, então, ela é ideológica.

Se irrefletidas, essas forças para a democratização da educação estética, da arte e da cultura podem ser canalizadoras e facilitadoras da semicultura, reflexo da imposição ideológica da indústria cultural, em que, como o foi o rádio (ADORNO; HORKHEIMER, 2006) - "Radio, what's new?" (TAYLOR, 1984) -, podem, ao contrário de seus objetivos mais bem intencionados, transformar todos em receptores estéticos imediatos, submetidos ao controle das forças que sustentam e mantêm os monopólios culturais, as mesmas que dilaceram qualquer possibilidade para a formação cultural. Vertem, deste modo, as pessoas, mesmo que em sua diversidade precária ou mesmo em sua diversidade potente mas enrouquecida no esquecimento das memórias do social, às correntezas bravias da sociedade de massas, despersonalizada, cada um dos que a compõe, da sua própria subjetividade, até cair no caudaloso rio da uniformidade, onde as diferenciações não mais são que um disfarce do mecanismo de controle da determinação social: uma sociedade sem tempo, desabitada de qualquer condição para o envolvimento, para a experiência e para a linguagem do éter, para qualquer possibilidade de inebriar-se em outros estados possíveis da consciência que não o da percepção imediata e passageira, seja pela língua dos anjos ou da poesia, seja pelo êxtase de um encontro com uma obra de arte ou com a criação de uma, assim, não determinada pelos seus afins pré-estabelecidos utilitaristas ou, então, sem ter a arte como o dinheiro do pão de cada dia para saciar a barriga da fome. Entrega-se, à contramão, a um encontro desavisado e passageiro em tempo-milímetro do sinal fechado, entre palavras cortadas, corridas metálicas e telegráficas (VIOLA, 1974), às dependências do poderio da indústria cultural, e que dificilmente conseguirão, mediante suas forças desiguais, escapar de seus 
tentáculos ideológicos. Perpetua-se a ilusão de democracia, perde-se o seu real sentido de formação cultural, que se expressa pela “[...] ausência de uma totalidade justa e reconciliada com o singular" (ADORNO, 2005, p.8).

Falar sobre democratização da cultura e da formação cultural requer, por sua vez, pensar sobre as condições objetivas e sociais para a sua acessibilidade e, sobretudo, sobre os recursos operantes para que seja possível, a partir (e não somente) do acesso à arte, à cultura e à educação estética, a experiência e o pensamento crítico. Esses recursos não operam somente na ordem concreta das coisas, mas também dizem respeito à capacidade de apropriação subjetiva de cada indivíduo (ADORNO, 2005) e, deste modo, da sua atividade intelectual. De nada ou pouco adianta pensar sobre a acessibilidade aos bens culturais se os corpos estão alheios ou impedidos subjetivamente à experiência, à imaginação, à fantasia, à liberdade e ao pensamento, submetidos a "situações dadas em relação às quais são impotentes, bem como a se manter numa situação de não-emancipação" (ADORNO, 2006, p.43).

Diante dessa situação, conforme Adorno (2005, p.6), “para uma ação mais próxima é urgente uma política cultural socialmente reflexiva - e, ainda assim, pouco seria central no que diz respeito à semiformação cultural", em detrimento do pragmatismo orientado por uma razão subjetiva.

Voltamos, mais uma vez, à necessidade de se pensar sobre a qualidade do planejamento político-pedagógico de ensino, seja dos projetos socioculturais, seja das ações educativas promovidas pelos movimentos culturais ou da educação de modo geral, de modo que estejam comprometidos com o desenvolvimento das "aptidões críticas" (ADORNO, 2006), condição necessária e insubstituível para resistir, quando possível, às pressões coercitivas da adaptabilidade social e da barbárie. A democratização da cultura no sentido de formação cultural dos indivíduos de uma sociedade consiste em uma práxis indissociável do conhecimento teórico refletido, sem o qual pouco haverá a conscientização quanto à falsa práxis da acessibilidade. Que, conforme Adorno:

O mundo, que a razão subjetiva tendencialmente só se limita ainda a reconstruir, na verdade deve ser continuamente transformado conforme sua tendência à expansão econômica e, contudo, sempre permanecendo o que é. O que mexe com isso é amputado do pensar: sobretudo, a teoria a que quer algo mais que reconstrução. Dever-se-ia formar uma consciência de teoria e práxis que não separasse ambas de modo que a teoria fosse impotente e a práxis arbitrária, nem 
destruísse a teoria mediante o primado da razão prática [...] (ADORNO, 1995, p.204, 205).

Portanto, para além da disponibilização de recursos materiais que possibilitem o acesso ao rico acervo cultural dos museus, teatros, cinemas, exposições artísticas, mostras culturais e bibliotecas, como também a participação em concertos, shows e eventos culturais exteriores às localidades comunitárias, além de se oferecer instrumentos musicais novos e de qualidade, como é o caso da escola de música participante da pesquisa empírica, a formação cultural enquanto uma educação para a democracia requer condições objetivas e sociais para que todas as pessoas, sem distinção, possam desenvolver-se de modo a poder se apropriar subjetivamente da cultura (ADORNO, 2005). Por assim dizer, o acesso à cultura não é condição suficiente para a concretude de uma formação plena de sujeitos pensantes e de uma consciência sensível para o seu envolvimento com a estética e com a arte. A democratização do acesso aos bens culturais não é o mesmo que uma educação democrática, esta exige a desconstrução e reconstrução de processos sociais e psíquicos muito mais profundos (ADORNO, 2006).

\subsection{A ambientação escolar, o direito universal e a consciência do próprio valor: um processo de socialização proponente para a formação de sujeitos?}

As condições estruturais oferecidas pela escola de música participante não eram esperadas, tendo-se em consideração o referencial panorâmico de equipamentos públicos e de projetos sociais no que diz respeito às suas instalações e à qualidade de seus recursos. Geralmente, pelo tipo de distribuição de verbas e investimentos públicos nas regiões urbanas mais pobres, como as periferias, nessas áreas são encontrados poucos aparelhos públicos voltados a projetos culturais. Quanto às iniciativas civis e comunitárias, muitas vezes seus projetos de cultura e de educação estética acabam sendo subsidiados por uma infraestrutura de qualidade secundária tendo em vista a dificuldade de captação de recursos por meio dos tão disputados editais e financiamentos públicos e/ou privados (TOMMASI, 2013), a concentração de recursos públicos destinados ao desenvolvimento de projetos culturais na cidade de São Paulo (CULTURA TRANSPARENTE apud MPC, 2013), além de patrocínios e doações em dinheiro e também de materiais usados. Em decorrência desses desafios, muitos desses projetos ficam nas dependências de condições precárias, tendo que ajustar os parâmetros e alcances de seu trabalho, sem falar da qualidade do serviço prestado que também fica comprometido. 
De todo modo, pela descrição da ambientação da escola de música visitada, a qualidade dos recursos oferecidos não é habitual, no que toca, especificamente, ao acesso a recursos materiais de qualidade para o proveito da educação musical. Até onde pudemos observar, pelo contrário, foi identificada uma situação de carência de políticas públicas voltadas à cultura no distrito de Pedreira e da Cidade Ademar.

A partir dos conceitos de reconhecimento e de direito, pudemos verificar elementos componentes das diferentes esferas de socialização já pelos dados empíricos de observação. Para Honneth (2003), o reconhecimento é conceitualmente compreendido por três formas distintas para tal, sendo essas: 1) o reconhecimento pela dedicação afetiva (amor, amizade, presentes nas relações primárias, especialmente); 2) o reconhecimento jurídico (o direito, expressão das relações jurídicas) e 3) o reconhecimento pelo assentimento solidário (presente nas relações sociais pautadas pela estima simétrica entre sujeitos). Conjuntamente a essas definições, a noção de reconhecimento mútuo se orienta por dois sentidos simultâneos e indissociáveis entre si: o da universalidade e o da individualidade, em que o primeiro diz respeito ao princípio de igualdade universal, ou seja, que todo e qualquer ser humano deve ser respeitado e reconhecido como pessoa, sem distinção através de valores ou da estima social; o segundo, por sua vez, refere-se ao respeito pelas particularidades individuais, ao reconhecimento tanto das suas dificuldades como das suas contribuições para a práxis comum. Isso caracterizaria, idealmente, uma forma de eticidade democrática, que, tal como exposto por Honneth $(2003$, p.152, 153), “[ [... abriria o horizonte cultural no qual os sujeitos com direitos iguais, poderiam reconhecer-se reciprocamente em sua particularidade individual pelo fato de que cada um deles é capaz de contribuir, à sua própria maneira, para a reprodução da identidade coletiva".

Primeiramente, quanto às disposições sociais gerais, nos deparamos com a nossa sociedade orientada (jurídica e socialmente) pelas ideias de status e de estima social, cuja construção racional e subjetiva do respeito social é mediada por um valor social, o qual, em decorrência, compreende em seu sentido a ideia de um reconhecimento individualizado, ou seja, que se dá a partir de realizações tidas como "valiosas" pelo conhecimento público justamente pelo fato de não serem, elas, partilhadas "[...] de maneira indistinta com todos os demais" (HONNETH, 2003, p.204). Em seguida, passamos a pensar sobre a estrutura e as condições oferecidas pelo projeto social participante e a sua relação com a ideia de respeito universal, naquilo que concerne ao reconhecimento de seus alunos enquanto sujeito de direito. 
Como detalhadas na seção de resultados, as condições materiais do projeto participante rompem com o cenário habitual caracterizado por poucos recursos destinados aos serviços e equipamentos públicos estatais ou angariados por projetos filantrópicos destinados às populações desse território. A qualidade da ambientação institucional, por mais que não pareça, nos revela dados significativos quanto ao investimento não somente material mas afetivo dos idealizadores e da equipe do projeto, no que diz respeito ao envolvimento e ao comprometimento deles com o projeto de educação musical, tal como é relatado por um dos entrevistados, segundo este, “[...] o pessoal viaja muito procurando recurso para conseguir manter o nível da escola" (B., professor de música, entrevista 2, Anexo D).

Frente à realidade de naturalização do sucateamento público da educação e da cultura, principalmente nas comunidades mais pobres, a disposição dos espaços, o seu cuidado, as suas cores, a disponibilização de instrumentos musicais novos, por exemplo, irão incitar sem dúvida as percepções imediatas de seus interlocutores (alunos do projeto e comunidade) quanto ao seu direito universal de acesso à educação artística. Não que projetos sociais e assistenciais, públicos ou privados, que possuam estrutura secundária e fazem uso de materiais reutilizados, de segunda mão ou que até construam os seus próprios instrumentos musicais com sucata, não tenham o seu valor, pois o têm, visto que os recursos materiais disponibilizados não são condições suficientes para a efetivação de uma educação formativa, a qual depende, sobretudo, da capacidade para a experiência e para o pensamento (ADORNO, 2006). Entretanto, isto não subtrai o fato de que esse costumeiro panorama referencial pode vir a reforçar e a naturalizar, mesmo que não se queira, cada vez mais condições estruturais determinadas pela nossa sociedade de classes e que pode interferir negativamente no processo de formação do auto respeito e da auto estima das crianças e dos adolescentes atendidos por esses serviços. Ou seja, reforçar cotidianamente, nos traços mais sutis daquelas vivências institucionais de educação, uma realidade posta e determinada socialmente: a de que eles, filhos das comunidades periféricas, têm menos direitos e devem contentar-se com pouco.

Para além da educação estética que se propõe, essa instituição contribui para o desenvolvimento de um importante aspecto para a formação humana: a consciência do seu próprio valor, um elemento essencial para a possibilidade da autonomia e da liberdade, condições inerentes ao processo de formação de indivíduos singulares (ADORNO, 2005). Este valor foi expressado nas cores das paredes da escola de música, nos esforços da equipe gestora para obter 
instrumentos e equipamentos novos e de boa qualidade, com professores com formação apropriada e específica em música, no ambiente limpo e bem cuidado e ao assegurar a seus alunos e alunas a continuidade e regularidade quanto à grade de atividades pedagógicas e culturais propostas. Tudo isso colabora coadjuvantemente com a formação do auto respeito, que só é possível mediante o reconhecimento de seu grupo social, de sua coletividade, no caso, das relações grupais presentes nesta escola. Trata-se, segundo Honneth, de:

[...] uma atitude positiva para consigo mesmo que um indivíduo pode adotar quando reconhecido pelos membros de sua coletividade como um determinado gênero de pessoa. Por sua vez, o grau de auto-respeito depende da medida em que são individualizadas as respectivas propriedades ou capacidades para as quais o sujeito encontra confirmação por parte de seus parceiros de interação; visto que "direitos" são algo por meio do qual cada ser humano pode saber-se reconhecido em propriedades que todos os outros membros de sua coletividade partilham necessariamente com ele, eles representam para Mead uma base muito geral, embora sólida, para o auto-respeito: "É muito interessante recorrer à própria consciência mais íntima e buscar aquilo de que depende a preservação de nosso auto-respeito. Naturalmente, há fundamentos profundos e sólidos. Manter a palavra, cumprir as obrigações. Isso já dá uma base para o auto-respeito. Mas trata-se aqui de propriedades que devem ser atribuídas à maioria dos membros de nossa comunidade. Todos nós falhamos às vezes, mas no geral respondemos por nossa palavra. Pertencemos a uma comunidade, e nosso auto-respeito depende de que nós nos vejamos como cidadãos seguros de si (HONNETH, 2003, p.137, 138).

Por outro lado, não podemos nos abster quanto ao tipo de percepção dos responsáveis e organizadores do projeto sobre o valor da qualidade da infraestrutura escolar oferecida na própria qualidade da educação musical proposta, uma vez que, a depender, a preocupação com a qualidade técnica-instrumental e da ambientação não somente tem a ver com uma forma de expressão de uma dimensão do reconhecimento e respeito a seus alunos enquanto sujeitos de direitos, mas também, pode dizer respeito a uma supervalorização desta alçada como pressuposto básico de ser uma das condições mais importantes para garantir uma educação musical de excelência quando, na verdade, não é, pois para isso, depende primordialmente da qualidade do planejamento educacional no que diz respeito à qualidade do planejamento de conteúdo (ADORNO, 2006). Ou seja, neste caso, não nos passa despercebida uma possibilidade factível de fetichização subjacente e estruturante da educação idealizada. O que, no âmbito dos aspectos materiais disponibilizados aos alunos do projeto, isso pouco foi possível de ser averiguado no discurso dos entrevistados. 
Além do respeito ao caráter de humanidade, imanente ao respeito e à materialização do princípio de igualdade universal, pudemos também verificar um apreço afetivo - além da generalização concreta do direito - que se aproxima da estima social igualitária, sem distinção em grau de valores sociais. Isso foi identificado em vários pontos da pesquisa: nas observações passivas, isso se expressou, por exemplo, tanto pelo fato de a escola de música residir em uma casa localizada em um bairro doméstico, pelo esforço da equipe coordenadora de manter uma dinâmica de livre circulação por todos os seus cômodos (portas e janelas abertas), pela disposição e pela organização de seus interiores serem semelhantes aos de um lar, pelas fotografias emolduradas nas paredes, e, principalmente, pelo tipo de relações observadas nesses espaços. Visivelmente, os alunos pareciam familiarizados, à vontade, e confortáveis na escola de música, e, além disso, as relações estabelecidas entre os educadores, equipe de coordenação e os alunos era de proximidade, familiar e cotidiana.

A aula de prática de conjunto descrita anteriormente evidenciou muito bem isso: seja pelas crianças acomodadas em círculo cada uma com um xilofone, à vontade no chão da sala de aula, ora brincando, ora rindo e ao mesmo tempo, atentando-se à harmonização da atividade coletiva, em detrimento de uma ordem linear, sentadas retilíneas em cadeiras duras com o seu professor à frente; seja pela maneira como o professor de música conduzia a atividade, atencioso e amigável; seja pelo embrulho azul celeste com fitinhas da mesma cor do presente da aniversariante do dia. Recolhendo as observações realizadas e voltando-se a elas novamente, mais uma vez, a sensação gerada rompe com as formalidades dos escritos acadêmicos, apáticos e telegráficos. A escola de música participante, para além de escola e de suas formalidades pedagógicas exigidas, mais parecia, afetivamente, uma casa aconchegante de "vó cantante", daquelas que apreciam as flores rubras de seu jardim e que perfumam a casa com o aroma fresco do café preto durante uma tarde comum.

A afetividade também se revelou marcadamente nas entrevistas coletadas: ficou evidenciada pelo tipo de relato pessoalizado e de proximidade ao falarem sobre seus alunos; por considerarem importante um acompanhamento atencioso e acolhedor quanto ao ritmo de aprendizagem de cada aluno, ao mesmo tempo que buscam motivar o desenvolvimento de suas capacidades criativas e expressivas (a criação de arranjos melódicos, a experimentação de novos desafios, subir no palco e fazer apresentações em público, por exemplo); como também, por um dos objetivos expressos do projeto social, o de garantir o direito à educação, à arte e à cultura 
àqueles que parecem não ter isso assegurado; por alguns dos princípios e valores elencados pelos entrevistados - dentre eles, o respeito, o amor, a amizade, o cuidado mútuo, a boa convivência e o acolhimento -; pela empatia que os entrevistados demonstraram ter em relação à realidade de seus alunos (familiar e comunitária); e através de um outro objetivo institucional, o de contribuir para a formação das crianças e adolescentes atendidos. $\mathrm{O}$ ambiente deste projeto se torna propício para uma proposta de educação acolhedora, um modo de enfrentar determinadas carências, de forma a promover uma ambientação, uma constelação de relações afetivas e seguras para que seus alunos e alunas possam melhor lidar ("ter um respiro") com possíveis situações de adversidade, onde também possam se sentir à vontade e com liberdade para desenvolver sua sensibilidade, suas capacidades criativas e expressiva. $\mathrm{O}$ que leva a pressupor haver elementos inerentes ao assentimento solidário, em que, de acordo com Honneth:

[...] sob as condições das sociedades modernas, a solidariedade está ligada ao pressuposto de relações sociais de estima simétrica entre sujeitos individualizados (e autônomos); estimar-se simetricamente nesse sentido significa considerar-se reciprocamente à luz de valores que fazem as capacidades e as propriedades do respectivo outro aparecer como significativas para a práxis comum $(2003$, p.210).

Tanto na perspectiva de Adorno (2006) como na de Honneth (2003, 2013), encontra-se um importante aspecto em comum para a enfrentamento da dominação social e da respectiva estrutura de relações sociais, organizadas e mantidas pela desumanização, pela apatia e impessoalidade das relações: a afetividade. Para Adorno (1993, 2006, 2011), trata-se da capacidade de estar disponível subjetivamente para o encontro com o objeto e para o relacionamento com o outro de modo a ser possível a experiência; a arte e a cultura, enquanto práxis humana autônoma e em suas potencialidades estéticas críticas, apresentariam conteúdos de verdades críticas potentes para a formação, transformação, ampliação ou maturação de uma consciência sensível. Para Honneth (2003, 2013), por sua vez, a ampliação gradual de reconhecimento, o avanço de uma intersubjetividade para uma sociedade democrática, depende da afetividade, enquanto empatia e solidariedade.

Uma leitura acerca de elementos componentes do arcabouço teórico-conceitual quanto à noção de reconhecimento à luz da prismática conceitual de experiência, educação política e formação cultural proposta por Adorno (2005, 2006), nos permite também compreender tais 
elementos identificados nessas relações como componentes relevantes para o avanço gradual do desenvolvimento psicológico de seus alunos, uma vez que relações com outras pessoas e, por assim dizer, o envolvimento afetivo, são uma força de resistência contra a apatia, hostilidade e crueldade socialmente generalizadas. No entanto, o conhecimento embasado quanto àquilo que os sustenta é tão importante quanto, como forma de ter entendimento esclarecido quanto aos mecanismos sociológicos e psicológicos envolvidos na formação da consciência regredida para assim não reproduzi-los - dentre eles, a ausência de relação. De acordo com Adorno (2006) em uma de suas conferências intitulada Educação após Auschwitz:

Se existe algo que pode ajudar contra a frieza como condição da desgraça, então trata-se do conhecimento dos próprios pressupostos desta, bem como da tentativa de trabalhar previamente no plano individual contra esses pressupostos. Agrada pensar que a chance é tanto maior quanto menos se erra na infância, quanto melhor são tratadas as crianças. Mas mesmo aqui pode haver ilusões (ADORNO, 2006, p.135).

A socialização afetiva e respeitosa propicia uma subjetivação que vem a se transcorrer na consciência de si mesmo enquanto sujeito de direito por meio da experiência cotidiana do reconhecimento afetivo e solidário por parte dos educadores e educadoras e, em decorrência, pelo desenvolvimento da auto estima e do auto respeito dos seus alunos, já que, segundo Adorno (2006, p.64), "para haver formação cultural se requer amor". Mediada por essa disposição afetiva amorosa para si , para o outro e, sobretudo, para o objeto de conhecimento, ainda mais no que toca o desenvolvimento infantil. Os alunos se desenvolvem de modo a se abrir para a relação, para o interesse e para a curiosidade, para um caminho de aprendizagem vívida e, consequentemente, para um esforço desejoso e espontâneo para assim realizá-la (ADORNO, 2006). Além disso, em contraste à barbárie, o assentimento solidário e afetivo faz tomar consciência sobre essa como algo que não deve ser aceito (desrespeito, coerção, violência, etc.), desnaturalizando-a e podendo-se fazer reduzir o conformismo e a submissão diante a essa realidade de desigualdade social.

Isto não significa, no entanto, o mesmo que dizer que o projeto social, na integridade do campo intersubjetivo formado entre seus pares, com destaque para as relações entre a dirigência, os educadores e os alunos, reconheça integralmente, no seu sentido conceitual, estes últimos. Visto que, para além da semântica universal do reconhecimento de qualquer ser humano 
enquanto sujeito de direito como um “fim em si” (HONNETH, 2003), há também a questão do respeito às particularidades dessas crianças e jovens, concernente às suas próprias demandas, potencialidades, repertórios culturais e às condições necessárias à sua formação cultural. Para Adorno (2006), por sua vez, o enfrentamento e/ou a superação objetiva da defasagem cultural dos grupos populacionais socialmente mais desfavorecidos, como as populações rurais e as comunidades periféricas, como objetivo educacional "[...] pressupõe um estudo da consciência e do inconsciente da respectiva população" (ADORNO, 2006, p.126). Concordante com Adorno, no plano da elaboração de um projeto de educação, esse respeito requerido por Honneth não se daria sem a compreensão sociológica e dos mecanismos subjetivos relativos, de modo a não se deixar levar por estereotipias, mas pelo contrário, de forma a resistir à teoria de mônades para que de fato haja a possibilidade para a intersubjetividade. De acordo com Honneth (2013), esta relação é esperada das formações grupais nos seguintes termos:

A experiência de ser considerado importante nas próprias carências, na sua capacidade de julgamento e, sobretudo nas suas habilidades precisa ser renovada e reconstruída pelo sujeito sempre de novo na vida em grupo, para que ela não perca sua força e vivacidade na anonimidade do outro generalizado (HONNETH, 2013, p.65).

Todavia, para Adorno (1995), o ativismo social solidário, se não atento quanto ao panorama de seus motivadores, pode convergir em uma solidariedade unilateral, retroalimentada por ganhos narcisistas coletivos. O envolvimento e o relacionamento humano, bem como reconhecer-se verdadeiramente como iguais, são imprescindíveis para a solidariedade genuína, no sentido de ser movido pela objetividade de uma situação concreta (desrespeito, desigualdade, injustiça social, por exemplo) de modo a se envolver e a se empenhar para a elaboração de uma práxis objetiva, ou seja, que não esteja fadada ao fracasso ou ao assistencialismo continuado, enquanto uma práxis que mais responde aos anseios de uma mudança a que a concretude de um mudança e, por assim ser, que sem se dar conta, vem a desembocar novamente na manutenção da engrenagem social que se busca romper (ADORNO, 1995, 2004).

A solidariedade como causa social é falsa e ideológica, pois, assim como no dinamismo do engagement, antecipa a própria relação, no caso em questão, com os indivíduos público alvo da ação social institucional correspondente, resultante, na verdade e contraditoriamente, da ideia que se têm sobre essas pessoas ao invés do próprio envolvimento intersubjetivo, consistindo, 
pois, em uma falsa relação ou, então, nos termos conceituais propostos por Adorno e Horkheimer (1973), em uma relação entre mônadas. Além disso, a solidariedade vem a ser convertida ilusoriamente em uma força produtiva, expressando a ausência de consciência quanto aos seus pressupostos subjetivos, os quais não se dão na medida que as decisões profissionais são tomadas nas circunstâncias de uma reunião de escritório, e sim pela própria emancipação dos sujeitos (pelo caminho da auto reflexão crítica). Esses requerem capacidades de se emocionar, de amar, ou seja, de "levar a cabo experiências humanas diretas [...]" (ADORNO, 2006, p.129), o que infere uma formação individual que supere uma estruturação subjetiva fechada ao outro, reprimida, disposição psíquica comum na sociedade imperativa da dominação social, da domesticação dos corpos e da consciência reificada.

A partir do material teórico consultado, pode-se inferir que a noção de intersubjetividade adotada por Honneth $(2003,2013)$, não obstante, pressupõe de imediato uma relação afetiva entre sujeitos, mesmo que essa se valha de uma hierarquia de estima social, quando, na verdade, tais afetos são decorrentes do próprio indivíduo coisificado e inapto à experiência. A afetividade, seja ela qual for, não necessariamente advém de uma relação, como parece se supôr, mas também de sua supressão, mesmo que haja o contato respeitoso entre pessoas e o seu acolhimento. O modelo de pensamento deste autor é interessante e permitiu fazer uma leitura analítica sobre o tipo de atuação das organizações sociais contemporâneas, bem como nos levou a concordar quanto à necessidade de ampliação gradual dos conteúdos de reconhecimento para a transformação das normas sociais que visem à coexistência entre o universal e o particular. No entanto, este autor pareceu ignorar ou, então, atenuou as implicações psicológicas da realidade organizada pela dominação social no que diz respeito à falência da aptidão às experiências e à da capacidade de pensar a realidade, ou seja, ao processo formativo humano que se converteu em pseudoformação. E por mais que haja elementos constitutivos da solidariedade e estes, dentro do contexto institucional, contribuíram para uma socialização mais igualitária, isso não significa que tenha havido uma relação entre indivíduos no sentido de haver intersubjetividade, mas com a perspectiva correspondente a um Eu generalizado identitário, além de ser uma tentativa de concretizar aquilo que foi idealizado de antemão, antes mesmo da relação direta.

Em relação à perspectiva crítica de Adorno e Horkheimer (1973) quanto à noção de indivíduo autônomo, pode-se concluir que, no escopo do material consultado, Honneth não compreendeu a teoria de mônades no desenvolvimento teórico dos conceitos de reconhecimento e 
luta por reconhecimento, correndo-se o risco de conduzir o leitor a um olhar deslumbrado tão somente para frente sem se levar em conta tudo aquilo que é preciso antes ser superado (ADORNO, 2005, 2006). Ao invés de resistir à mônada psicológica, conforma-se a ela ao se perpetuar a alienação quanto a essa na própria produção de conhecimento. Para o reconhecimento mútuo, cabe mais que respeito, mas também, a compreensão e a crítica quanto aos determinantes sociais envolvidos na formação psicológica daqueles que são socialmente marginalizados. Deste modo, para o cumprimento do processo de transformação social para a democracia, tal como sugerido por este autor, é preciso antes propiciar condições para a intersubjetividade (uma vez que esta não está dada), superando a psicologia e os determinantes sociais que a impedem. Para isso, segundo é constatado por Crochik, "O estudo da mônada é necessário como crítica à ideologia, no sentido de negação determinada" (CROCHIK, 2001, p.21).

\subsection{As práticas das organizações socioculturais e educativas: práxis para a resiliência ou para a emancipação?}

A partir do material empírico e bibliográfico investigado, identificou-se um conjunto similar e constante de sentidos atribuídos à arte, todos eles marcados pela tônica de uma dimensão política social: a da resiliência, a da socialização e a do desenvolvimento humano. Essas dimensões foram compreendidas como fenômenos viabilizados pela educação e pela arte de modo a contribuir com a transformação social e para o desenvolvimento humano para a cidadania, seja pelo tipo de relações grupais inerentes a esses processos (afetivas, acolhedoras, solidárias, amigáveis e familiares), seja pelo tipo de valores, princípios morais e condutas enfatizados para o convívio grupal musical e para o desenvolvimento da relação de aprendizagem musical (respeito, atenção, disciplina, comprometimento, responsabilidade, por exemplo), seja pela compreensão quanto à potencialidade da arte para a sublimação de sentimentos e emoções e para a desconstrução de estereótipos e preconceitos sociais por meio da ressignificação afirmativa de novas estéticas locais e, por meio desta, da visibilidade do repertório cultural das periferias em contraste com as noções de falta, pobreza e de carências, seja também pela tônica do reconhecimento, da identificação e da autoestima.

Apesar da diversidade de concepções de arte e de música apresentadas pelos entrevistados, mais especificamente, estes destacaram elementos em comum de sentido conferidos a esses campos de saber, todos eles organizados e orientados pela diretiva de um 
sentido de função social e assistencialista. Em todas as falas, a arte e a educação musical foram compreendidas como formas possíveis de se responder às adversidades e problemáticas familiares e comunitárias das periferias. Assim como nas demais organizações sociais (GOHN, 2015), tais concepções são definidas, dentro do escopo contextual institucional, a partir das perspectivas (e, também, motivações e causas sociais e assistenciais) que se têm sobre os seus principais territórios de atuação (áreas urbanas e rurais pobres, periferias e favelas, principalmente). Foram destacados pelos entrevistados, por sua vez, o caráter de expressividade, de comunicação e de socialização, da sensibilidade e do desenvolvimento de senso crítico, como se pode observar nas seguintes conceituações de arte e de música a seguir:

[...] a arte é o respiro do existir, a arte é o respiro da humanidade. Acho que, assim, todos nós temos situações na vida boas e muito ruins e que a gente tem a necessidade de se expressar, de se fazer valer, de se emocionar, de a gente ter um caminho de fato que a gente possa se fazer presente mesmo, se fazer consciente. Acho que qualquer pessoa, em qualquer situação, precisa ter um canal de escape ou onde se possa identificar e aonde possa absorver aquilo que vê e equilibrar, acho que é isso. Acho que a arte equilibra a existência humana. [...] ela acaba atravessando a vida das pessoas...(A, coordenadora pedagógica, entrevista 1 , Anexo D).

A arte é um alimento pra alma, para se poder expressar uma coisa mais profunda, mais interior do ser humano, e acho que só mesmo através da arte que se consegue esta manifestação. Então, tanto pra mim, como na comunicação com as crianças e os jovens, é estimular essa forma de expressão neles. Eu acho que é extremamente importante em qualquer contexto, mas principalmente neste contexto onde a gente atua, porque as crianças vêm de situações, de famílias, às vezes, assim, muito maltratadas, com uma bagagem muito pesada. Então, entendo que a cor, a sonoridade, tudo isso, acho que vai como que limpando todos esses traumas, todos esses pesos que estão em vidas tão jovens. Acho que, realmente, vejo a arte como transformadora do ser humano, do seu interior $(C$, presidente, entrevista 3, Anexo D).

A arte é uma oportunidade de você se expressar, é uma oportunidade de você se comunicar, é uma linguagem! [...] uma forma também de crescimento! [...] eu vejo a música como um fenômeno transformador [...] oportunidade de transformação, oportunidade de crescimento, de entrega, de disciplina. São tantos benefícios que ela traz que vão ajudar nessa construção do ser humano (E, professor de música, entrevista 5, Anexo D).

Para além de se ter identificada uma relação com a arte convergente com a ideia de arte engajada, verificou-se também que esse entendimento sobre a arte fora empregado como uma 
solução possível para o enfrentamento de uma realidade compreendida a partir de um conjunto de pressupostos e perspectivas estereotipadas - e, portanto, ideológicas - acerca do que vem a ser periferia, cujos conteúdos foram consonantes às perspectivas unilaterais negativas e à teoria de mônades, discorridas no primeiro tópico dessa discussão, em detrimento de um conhecimento consistente e sociológico crítico acerca da periferia enquanto comunidade também ativa e produtiva. Isso foi evidenciado pelo desconhecimento quanto aos movimentos e coletivos culturais comunitários atuantes nas regiões de Pedreira e da Cidade Ademar, mais especificamente, e da extrema zona sul de São Paulo, de modo geral; como também, pelo pouco contato, comunicação e relação estabelecidas com a comunidade periférica à sua volta (questão pouco referenciada durante as descrições das atividades do projeto social e pouco verificada durante as observações de campo). E que, consequentemente, implica em uma contextualização pouco precisa acerca da região periférica atendida, somada ao fato de que tais perspectivas estereotipadas acerca das periferias foram, certo modo, ratificadas pelo conhecimento referente aos dados de vulnerabilidades sociais, citado por parte dos entrevistados, que, apesar de consistir em dados empíricos validados (e que também foram consultados e confirmados durante a atividade do mapeamento territorial), esses se referem a informações parciais sobre tais territórios, deixando-se à margem a necessidade do conhecimento quanto à própria psicologia dessa população e quantos aos aspectos sociológicos envolvidos em sua formação (ADORNO, 2006).

Esse tipo de entendimento parcial e total sobre as periferias reforça, todavia, as noções de falta, carências e violência, ao mesmo tempo que também foi observado, por vezes, um atenuamento da consciência quanto aos determinantes sociais inerentes a essa realidade, estabelecendo-se relações onde a ênfase casuística de tais problemáticas recaiu equivocadamente sobre a própria região periférica e sobre os que lá residem, como se parte dessas questões se devessem a um estado de ser-assim enquanto natureza própria, "como um dado imutável e não como resultado de uma formação" (ADORNO, 2006, p.132). O que, por fim, dá-se a identificar um estado de condicionamento da consciência dos responsáveis pelo planejamento e efetuamento da práxis educativa proposta; muito possivelmente, isso se dá também pela influência dos meios de comunicação de massa sobre as suas formas gerais de entendimento, em detrimento do próprio envolvimento e relacionamento com a comunidade vizinha. 
De forma geral, coincidente com o tipo de racionalidade que sustenta uma práxis de engagement, característica das organizações sociais, os sentidos conferidos à arte e os que compuseram os conteúdos dos objetivos, princípios, valores e missões do projeto em questão são comuns ao que se espera de uma educação enquanto práxis oportuna para o enfrentamento da barbárie social, porém, ao contrário desta, a função política social empregada diz mais respeito ao processo de resiliência do que ao processo de emancipação, visto que foram destacadas preocupações voltadas sobretudo às demandas emergenciais relacionadas às questões de sobrevivência e autoconservação física e subjetiva de seus alunos, e menos acerca das condições necessárias para a qualidade do sistema de ensino-aprendizagem da música e para a auto reflexão crítica. Ou seja, o caráter assistencialista e a intenção subjetiva para a resiliência comprometem a própria qualidade da educação no sentido de ser uma práxis consciente e consistente que garanta experiências estéticas formativas iniciais que possam contribuir para o processo de socialização para a individuação e para o desenvolvimento das capacidades inerentes à formação cultural: para o desenvolvimento e maturação possíveis de uma consciência sensível futura de modo a se colaborar com o esclarecimento e com uma formação psicológica para a autodeterminação e que, por meio da qual, já não seja mais possível a continuidade da atomização do gosto musical, da consciência moral reificada, da pseudocultura e, por fim, que a barbárie não mais se repita. Desta maneira, pode-se identificar nessa racionalidade a sua irracionalidade frente à primazia do objeto, que se perde: tanto a arte em sua autonomia, como a educação em sua potencialidade formativa planejada para a emancipação (ADORNO, 2006). Sendo assim, quanto a esse tipo de práxis e, mais especificamente, ao tipo de conceito que pouco a fundamenta teoricamente, de acordo com Adorno (1995):

[...] desmascara-se como desacertada e contraditória em si. A 'ratio' não pode ser menos que autoconservação, a saber, a da espécie, da qual literalmente depende a sobrevivência de cada indivíduo. Passando pela autoconservação, ela decerto alcança o potencial daquela auto-reflexão que algum dia poderia transcender a autoconservação, a que ela foi reduzida por sua limitação ao nível do meio (ADORNO, 1995, p.222, 223).

Quanto à qualidade conceitual de arte, a partir da perspectiva dos educadores entrevistados, pudemos pressupor que os sentidos de arte eleitos por eles corresponderam tanto a essa função social determinada e prevista à arte e à educação, como também, pela própria 
observação, nesse sentido, da evolução pessoal de cada aluno no que se refere ao envolvimento e progresso da aprendizagem musical, e ao desenvolvimento pessoal de cada um - capacidades de socialização e de expressividade, sobretudo.

As noções apresentadas pelos entrevistados pouco indicaram uma fundamentação teórica e que, inerente a isso, pouco consideraram elementos constitutivos de sua lei formal (ADORNO, 1993), na verdade, em nenhum dos entrevistados, tal comprometimento foi evidenciado. A concepção de arte dos entrevistados foi diversa, apresentou entendimentos bastante genéricos e simplistas, na maioria dos casos, tais noções conceituais tinham caráter de senso comum: as definições de arte e de música partiram de conteúdos mais informais e romantizados; três deles apresentaram compreensões superficiais ("a arte é o respiro do existir"; "uma alimentação pra alma"; "arte é tudo"), os demais trouxeram alguns poucos elementos conceituais formais inerentes ao campo do estudo da arte (belo, linguagem artística, elaboração estética) e, mais especificamente, da música (material sonoro, caráter expressivo). Não coincidentemente, ao longo das entrevistas, esses dois últimos entrevistados demonstraram maior apropriação conceitual inerente ao contexto de suas práticas pedagógicas e um entendimento mais reflexivo sobre o método utilizado pela escola, bem como a sua relação com uma educação musical que promova condições para a formulação de percepções mais críticas; sendo também observados relatos mais detalhados e compreensões mais coesas de sentido sobre o tipo de educação musical proposta, sobre o sistema de ensino-aprendizagem e sobre o desenvolvimento de seus alunos nesse espaço formativo em questão. Como se pode verificar no trecho a seguir:

[...] ela te leva a entender a construção da música, não só "pega e ensaia", vai lendo, sai rezando. Ninguém merece isso! Não. Eu entendo que essa metodologia, ela te leva a entender a parte teórica e a parte prática, pensando não só na construção musical, mas no entendimento da linguagem que é a música, que é você entender o que é trabalhar com um material sonoro, que é vocè entender que essa música tem uma forma, que é você entender que ela também tem um caráter expressivo e entender que ela tem um valor para você (E., professor de música, entrevista 5, Anexo D).

Os objetivos, princípios, missões e valores enumerados pelos entrevistados também apresentaram pouca objetividade - simples, genéricos e óbvios dentro de uma sociedade que vise ao bem-estar coletivo e individual, ou seja, dentro de uma ordem social idealmente democrática , os quais foram indicados de forma desvinculada de considerações necessárias quanto à 
complexidade dos processos sociológicos e psicológicos inerentes a cada um deles e da caracterização de uma práxis consistente e planejada para a sua efetivação no sentido de contribuir, de fato, para a formação de sujeitos sensíveis e autônomos e, deste modo, capazes de estabelecer relações fomentadas por uma intersubjetividade cidadã e democrática. Os conteúdos variaram desde valores básicos para a democracia, a garantia de direitos universais, elementos constitutivos de uma socialização afetiva e o assistencialismo.

Dentro desse panorama, a educação musical deixou de ser um fim para se tornar um meio para outra coisa: um enfrentamento positivo e sensível das adversidades sociais e, contíguo a isso, meio para se ensinar valores morais da conduta humana. Os quais, apesar de serem fundamentais em qualquer que seja a circunstância das relações, deveriam estar situados intrinsecamente e espontaneamente nas relações dentro do contexto da educação, no campo da própria experiência de amor, respeito, amizade e de modo a se tê-los em conta conjuntamente por um processo educativo (ainda mais se pensando na importância da educação na infância) - e se assim for possível verdadeiramente -, e não como intento subjetivo a ser pregado enquanto uma outra estrutura de caráter e que, assim melhor viabilizaria uma "cultura da paz", tendo-se que, na verdade, "o incentivo ao amor - provavelmente, na forma mais imperativa, de um dever constitui ele próprio parte de uma ideologia que perpetua a frieza" (ADORNO, 2006, p.135).

Pela ênfase nos conteúdos elencados, a música, enquanto conteúdos estéticos, torna-se, contraditoriamente, o objetivo principal formal, porém, objetivo secundário no campo da perspectiva subjacente à práxis do projeto em questão, tal como se pode identificar nos seguintes trechos das entrevistas realizadas:

A música, sem dúvida alguma, que é o nosso objetivo principal, mais que pensar em formar músicos profissionais e que possam despontarem na carreira, a gente pensa, sem dúvida alguma, em formar melhores pessoas: que possam ter disciplina consigo, que possam saber andar em conjunto, que tenham paciência, que saibam escutar. E isso é uma coisa que a gente trabalha diariamente em todas as aulas e em todas as atividades. A música precisa, mais que precisa, ela tem essa disciplina, então, assim, mesmo que subjetivamente, os alunos também estão absorvendo isso (A., coordenadora pedagógica, entrevista 1, Anexo D).

A gente fala muito sobre o respeito com eles, do bom comportamento que o músico deve ter, de ter disciplina. Não é fácil ser músico, tem que estudar muito. A gente fala sobre isso com eles, e a gente fala da relação que eles vão ter com o trabalho também, que o que eles aprenderem aqui, eles vão levar pro trabalho também. [...] Os meninos estão ficando bons! Mas não é por isso que a gente faz 
música, a gente quer que eles sejam bons cidadãos, que eles cresçam e saibam respeitar os outros, que ajudem a construir uma sociedade melhor (B., professor de música, entrevista 2, Anexo D).

Enquanto instituição, a gente tem ali a nossa missão, visão e valores, e esses permeiam todos os nossos projetos. Então, assim, nós entendemos a promoção de uma cultura de paz. É isso que a gente entende que a arte também está promovendo, né, tanto através das artes plásticas, como da música, como de todas as outras atividades que a gente faz. Que a gente está numa comunidade violenta, com diferentes números de problemas ligados à droga, ao álcool, à violência contra a mulher..então, assim, entre esses valores institucionais, tem a paz e a verdade. [...] A gente está cercado de crianças que têm muitos problemas de afetividade, ausência de figuras importantes na família, pai, mãe, enfim..e, aí, a gente acaba também sendo presente nesse sentido, a gente se torna a segunda família, muitas vezes, a primeira família. Então, é um espaço que acolhe, que abraça, que acompanha os problemas (C. presidente da associação, entrevista 3, Anexo D).

À luz da compreensão de estética e de arte em Adorno (1993), considerando, sobretudo, o caráter de liberdade e autonomia da própria obra como condição para a expressão autêntica de conteúdos de verdade, de negação e de experiência estética, pensar sobre a arte engajada e sobre a educação engajada por meio da música nos leva ao encontro de alguns paradoxos, uma vez que estas passam a conter intenções subjetivas (ou seja, determinadas pelo sujeito) em detrimento do próprio objeto (a arte e a educação musical). As quais são anteriores à própria música, antecipando-a com sentidos de uso político e social e, consequentemente, comprometendo a sua primazia e, por sua vez, a sua consistência objetiva e estética, as condições para o contato inicial enquanto uma musicalização para a experiência formativa.

Tendo-se a ênfase sobre fins de resiliência, a educação para a democracia se esvazia de sentido objetivo, limitando-se, dessarte, a essa; contrariando, pois, a própria efetividade da função social prevista à arte. O que dá indícios de uma práxis regressiva, no sentido de que, movida por idealismos e esperanças ideológicas, a subjetividade que a organiza se nega a reconhecer a sua própria debilidade e impulsos maníacos, negando a própria realidade objetiva e a sua impotência diante a essa (ADORNO, 1995). E que, pela ausência da auto reflexão, impede, consequentemente, o planejamento consciente e objetivo de uma educação para a emancipação de fato. Isso ocorre de forma a se avaliar que, ainda hoje, se mantém contundente a compreensão crítica de Adorno (2006) quanto à real possibilidade de uma mudança social, a qual só se daria mediante a capacidade de consciência das pessoas quanto ao estado deliberado do fascismo 
inerente ao processo da dominação social. Para este autor, portanto, "é extremamente limitada a possibilidade de mudar pressupostos objetivos, isto é, sociais e políticos que geram tais acontecimentos, as tentativas de se contrapor à repetição de Auschwitz são impelidas necessariamente para o lado subjetivo" (ADORNO, 2006, p.121).

Segundo Gohn (2009, 2015), o núcleo orientador desse tipo de projeto é constituído pelos próprios pressupostos incorporados em seus princípios e objetivos e, consequentemente, elementos também presentes e enfatizados na conceituação de arte e de música - os quais também orientam, conforme esta autora, o próprio planejamento político-pedagógico -, o que, por sua vez, antecede a prática de ensino-aprendizagem, cenário possível para a verificação da relação entre os alunos e a música: “O conteúdo desse conjunto, principalmente no que se refere às crenças, usualmente é anterior à existência de um grupo, extrapola seus limites e fronteiras" (GOHN, 2015, p.24). Tal entendimento se reforça, no caso desta análise empírica, ao se resgatar a questão da perspectiva estereotipada dos educadores em relação aos seus alunos e a relação da arte para com aquela que passa a ganhar um sentido de solução para as problemáticas periféricas evidenciadas nas entrevistas, ou seja, a arte é transformada em uma estratégia sociopolítica interventiva dos projetos sociais, passando a configurar em um uso instrumental da arte. A educação, contíguo a isso, de acordo com Gohn, “[...] é construída por escolhas ou sob certas condicionalidades, há intencionalidades no seu desenvolvimento, o aprendizado não é espontâneo [...]” (GOHN, 2015, p.16). Isso faz sentido na lógica de atuação destas organizações (GOHN, 2009, 2015), porém, tratando-se de educação e de arte, e a partir da leitura desses conceitos em Adorno (1993, 1995, 2006, 2011), nos defrontamos com algumas significativas contradições. Primeiro, no que diz respeito à compreensão quanto à autonomia da arte, esta vem a ser, diante disso, “[...] a crítica da práxis enquanto não-liberdade” (ADORNO, 1995, p.206), como já discorrido na seção anterior. Segundo, há uma séria contradição no que diz respeito à superação da crise social pela educação: a barbárie só será superada mediante a desbarbarização das pessoas por meio de uma educação emancipatória e não pela conversão dos próprios campos educativos formativos em forças produtivas (ADORNO, 2006).

Por mais que as concepções de arte e de música verificadas também sejam oriundas de considerações desse tipo de práxis pelos entrevistados e por mais que tenha sido verificado esse potencial transformador da arte e da educação musical em alguma instância de sua práxis, esse sentido da arte passa a ser fixado e totalizado e por fim, passa a ser previsto, significando, 
consequentemente, o seu esvaziamento, a morte da sua primazia, tendo-se em consideração que, para Adorno (1993), a partir da perspectiva de que todo objeto é histórico, também a “[...] arte tem o seu conceito na constelação de momentos que se transformam historicamente; fecha-se assim à definição" (p.12). Ao que parece, a arte tornou-se figurativa de si mesma, cuja performance em seu sentido político cultural foi determinada e fixada anteriormente à própria possibilidade de experiência estética e formativa, a qual só se dá mediante a sua própria liberdade, espontaneidade e autonomia (ADORNO, 1993, 2011).

Pelo tipo de conceituação apresentada, a arte perde a sua potencialidade objetiva para a formação de uma consciência sensível, recaindo nas malhas dos mecanismos da cultura administrada ao cumprir uma função política social de engagement, revelando seu sentido de uso que, mesmo não sendo determinado pela lógica do lucro, reproduz a lógica da racionalidade administrativa e acaba por ser revertida em uma força estética produtiva com caráter ilusório de transcendência do espírito humano em detrimento da real espiritualização da arte e do indivíduo. Segundo Adorno:

O momento da práxis objectiva, que é inerente à arte, torna-se intenção subjetiva quanto a antítese da arte à sociedade se torna irreconciliável, pela sua tendência objectiva e pela reflexão crítica da arte. $\mathrm{O}$ nome corrente para isso é o termo de engagement. $\mathrm{O}$ engagement é um grau de reflexão mais elevado do que a tendência; não quer apenas melhorar situações pouco apreciadas, embora quem se empenhe simpatize demasiado facilmente com as medidas tomadas; visa a transformação das condições conjunturais e não proposições estéreis; nesta medida, o engagement inclina-se para a categoria estética da essência. A autoconsciência polêmica da arte pressupõe a sua espiritualização; quanto mais intolerante se torna à imediatidade sensível à qual, antes, era equiparada, tanto mais crítica se torna a sua atitude perante à realidade bruta que, prolongamento do estado natural, é alargada e reproduzida pela sociedade. Não é de um modo apenas formal que o carácter criticamente reflexivo da espiritualização reforça a relação da arte ao seu conteúdo material (ADORNO, 1993, p.275).

Assim como a arte engajada, a educação estética no contexto das organizações sociais é reduzida por um entendimento dissociado da teoria, por um entendimento dirigido pelos anseios subjetivos (de ajudar o próximo, de resistência, da transformação social, etc.) e, em decorrência pela tendência do pragmatismo. Não mais se relacionam com a arte e com a educação: para isso a teoria e a conscientização esclarecida decorrente quanto à autonomia da primeira (ADORNO, 1993), quanto aos mecanismos sociais e psicológicos da dominação social e da semicultura 
presentes na própria ordem da instituição educacional e quanto ao esclarecimento acerca do papel de uma educação política e das condições para tais (ADORNO, 2006). No entanto, o que ocorre é uma formulação de práxis sustentada nos pressupostos ou em conhecimentos formais mínimos que se têm sobre a arte e a educação, cuja potencialidade política é tida como garantida por si só, ficando à margem a necessária conscientização quanto aos princípios elementares do pensamento criador. $\mathrm{O}$ que evidencia a ausência de auto reflexão quanto à própria práxis, a sua ingenuidade e o risco eminente de se tornar uma práxis aparente para a educação musical no sentido de contribuir para a formação de indivíduos autônomos, quando, na verdade, se limita ao assistencialismo resiliente e que pode estar apenas correspondendo a um pretexto ideológico inconsciente - e do mesmo modo, permanecem inconscientes os mecanismos subjetivos proponentes que o operam -, além de não se ter em vista as perspectivas concretas de sua ação para a formação cultural. Isso é expressão das condições sociais objetivas do mundo administrado (da supremacia da racionalidade técnica instrumental), às quais os projetos sociais e os seus idealizadores não estão imunes por mais que estejam conscientes quanto aos fenômenos de desigualdades e de injustiças sociais decorrentes dessa mesma realidade. Na ausência da apropriação reflexiva de um conhecimento teórico (sociológico e psicológico) mais aprofundado, pois, a práxis social engajada da educação é reduzida ao que Adorno (1995) irá denominar como pseudo-atividade:

[...] práxis que se tem por tanto mais importante e que se impermeabiliza contra a teoria e o conhecimento tanto mais assiduamente quanto mais perde o contato com o objeto e o sentido das proporções" (ADORNO, 1995, p.217).

Tal como o termo de engagement, a educação musical é compreendida pelos entrevistados como uma prática que pretende gerar emancipação, mas que, pela pouca apropriação teóricaconceitual reflexiva apresentada por esses, o sentido de emancipação é reduzido a conteúdos essencialistas de resiliência, vinculados a uma conceituação mítica e dogmática de arte, cultura e educação (ADORNO, 2004), limitando-se a uma prática voltada predominantemente para a adaptabilidade social ("deixar momentos bons, momentos felizes"; "vai como que limpando todos esses traumas"); socialização e comunicação; pertencimento grupal; apresentações musicais em shows e concertos com função de entretenimento; profissionalização e possibilidade de 
entrada no mercado de trabalho, etc., a que para o início de um processo educativo formativo para a conscientização sensível e para o desenvolvimento inicial de uma racionalidade individual.

Tendo-se em vista o estado deliberado da dominação social, da condição do mal-estar evidenciada, da semicultura e da pseudo individuação que caracterizam a sociedade vigente, cujos mecanismos são herdeiros históricos do fascismo ainda não superado, cabe à educação tomar consciência de si de modo a se ter "[...] neste momento de conformismo onipresente muito mais a tarefa de fortalecer a resistência do que de fortalecer a adaptação" (ADORNO, 2006, p.144), por mais que esta seja também necessária para o viver coletivo. Como resistência, pois, não se trata apenas de impedir a derrocada de uma formação ou um estado psicológico já enfraquecido, mas de conscientizar-se quanto à realidade que nega a sua individuação de forma a deixar-se de subestimar a perspicácia dos mecanismos de controle e da dominação social, sobretudo, que isso se torne consciente na e por meio da educação para a experiência e, deste modo, para a emancipação (ADORNO, 2006).

Portanto, pensar sobre a práxis educativa e formativa que envolve a arte e o ensino das suas diferentes modalidades no contexto das organizações sociais infere refletir criticamente quanto aos sentidos conceituais, aos princípios e valores, aos objetivos institucionais e aos métodos empregados, pois, como se pôde verificar, os projetos sociais se identificam com o caráter político cultural dos processos formativos, o que pode, na ausência de uma práxis (auto)reflexiva crítica, restringir-se ao pragmatismo e limitar-se à recorrência do papel social da arte e da educação enquanto conceito de resiliência, em detrimento do desenvolvimento de uma planejamento político-pedagógico comprometido objetivamente com o processo de formação e emancipação de seus alunos, com o exercício constante do pensar. De acordo com Adorno:

En primeiro lugar, no se podrá exigir otra cosa que una política cultural muy pensada en sí misma, consciente de todas esas dificultades, que no se imponga el concepto de cultura de forma cósica, dogmática, como entramado fijo de valores, sino que acepte y desarrolle consideraciones críticas; una política cultural que ni se confunda a sí misma como designio divino, ni se suscriba sin el menor reparo a la fe en la cultura, pero que tampoco se conforme con la función de mero órgano administrativo (ADORNO, 2004, p.133).

Diante disso, os processos educativos para a resiliência e para a emancipação distinguemse pelo alcance de suas propostas (objetivos mais pontuais versus objetivos processuais, contínuos à consciência quanto ao próprio desenvolvimento humano), pela necessidade imanente 
e consciente quanto à essencialidade da experiência estética e formativa a qual, por fim, se dá mediante a relação entre sujeito e objeto e entre teoria e práxis.

\subsection{Educação musical e formação cultural}

Em relação a todo o material empírico coletado, os conteúdos referentes à educação musical proposta pelo projeto social participante são os que aparecem melhor estabelecidos, organizados e fundamentados conscientemente pela equipe profissional responsável, tendo-se que ao caracterizá-la, todos os entrevistados discorreram sobre essa com maior apropriação e segurança em suas falas. De modo geral, os objetivos institucionais formalizados, elencados e apresentados no website do projeto, diferentemente dos indicados nas entrevistas, dão destaque para a musicalização infantojuvenil no sentido do desenvolvimento e da habilitação da prática instrumental, especialmente; como também, por meio dessa, buscam apresentar um repertório musical ampliado da música popular brasileira e internacional. Em nenhum desses objetivos, o estudo da teoria musical foi indicado, ao contrário, foi pouco mencionado nas entrevistas. Ademais, a teoria musical está disposta em segundo plano na estruturação do método pedagógico adotado. De acordo com o material investigado, o modelo T.E.C.L.A é organizado pelas etapas da Técnica, Execução, Composição, Literatura e Apreciação, e dentre essas, o ensinoaprendizagem se baseia, principalmente, pelas três primeiras etapas.

Essa primeira disposição do planejamento pedagógico já indica uma relação de disparidade cisória entre teoria e práxis, o que, por sua vez, nos leva a questionar quanto ao tipo de sentido e finalidade estabelecidos para a educação musical por esse projeto: será que esta educação de fato compreende o sentido amplo e cultural da educação (COSTA, 2017)? Para qual requer uma práxis reflexiva, que é indissociável do conhecimento teórico como substrato para se desenvolver uma percepção musical reflexiva acerca dos conteúdos sociais e culturais imanentes da estética musical (ADORNO, 1993, 1995, 2011).

Como já dito anteriormente, apesar de as formações humana e cultural terem aparecido em todas as falas como um dos sentidos atrelados à educação musical, o sentido e a finalidade da resiliência se sobrepôs a esta, o que infere que esta educação musical esteja mais planejada para corresponder a uma função social assistencialista a que com o comprometimento com uma educação musical planejada para a formação cultural. Deste modo, restringindo a sua potencialidade para a formação de uma consciência sensível, cujo princípio do pensamento 
criativo (ADORNO, 2006), na verdade, deveria ser a pedra angular de qualquer educação estética. De acordo com Costa, baseado nas ideias de Adorno, essa educação: :

[...] é pautada na consciência das percepções culturais e sociais como princípio formativo. Reconhecer os pontos de tensão existentes na relação entre universal e particular, objetividade e subjetividade, sujeito e objeto é fundamental. Nessa proposta educativa, o sujeito deve refletir sobre si mesmo e sobre o contexto social. E sendo a música mediadora desse processo, o caminho percorrido deve ter como intenção proporcionar o reconhecimento de como forma e conteúdo são of erecidos como estímulos a novas percepções, ou, como possibilidade de emancipação e alienação. Dessa forma, o sujeito deve compreender a essência da obra artística em sua aparência, o que se daria com o desenvolvimento da criatividade e da crítica, com o momento da interpretação e a apreciação. $\mathrm{O}$ objetivo é alcançar a emancipação em uma consciência (est)ética da sociedade, do indivíduo, da cultura e da vida (COSTA, 2017, p.11).

Retomando os dados empíricos, com a orientação dessa conceituação de educação estética, verificou-se o intento de uma educação musical que viabilize uma percepção musical dotada de juízos críticos em detrimento de uma educação que se limite à reprodução instrumental mecânica, conforme é indicado nos seguintes trechos das entrevistas realizadas:

[...] mas que não seja uma coisa totalmente quadrada, que eles só aprendam a nota no pentagrama e que sejam reprodutores, máquinas, reprodutores daquilo que estão aprendendo, mas eles também são estimulados a criar, a improvisar (A., coordenadora pedagógica, entrevista 1, Anexo D).

Outra preocupação que é nossa não é tanto quanto tipo assim: o aluno tirou 8, isso não é interessante. O aluno entendeu? Bem mais que "ah, mas eu tirei quanto?" - Sei lá quanto você tirou! Você entendeu isso daqui? Você vai conseguir usar isso daqui na sua prática de conjunto? Isso aqui que você está estudando, você vai conseguir usar quando você subir no palco? Pode até ser que a gente pense em nota para fechar, quanto eu vou atribuir de nota. Mas, você consegue compreender que há uma preocupação de que o aluno realmente compreenda aquilo e saiba usufruir daquelas ferramentas. Muito mais do que você prendê-lo: “oh, é aqui e vai!". Eu passei por esse tipo de estudo, ninguém merece! Não, trabalhamos aqui de forma mais ampla, de modo que leva o aluno a compreender a música, a manipular o seu material sonoro, entender que ela tem forma, que o material sonoro vem desde a escala, tudo que é o som, o ritmo, a tonalidade.. Mas eu vou entender que essa música tem uma forma, eu consigo envolver essa apreciação, essa formação cultural que desenvolva intérpretes e apreciadores. Que é diferente do "ah, põe uma música aí! Ah, eu ouvi, Ah, eu decorei a letra desta música". Não! Você entendeu a forma desta música, você consegue compreender esta música, como ela é. E se você tiver que interpretar? E o valor que a música tem pra você? Então, essa formação musical que não 
forma tão somente o músico, que pode se tornar um profissional futuramente, ou não, mas que forma um ser humano! (E., professor de música, entrevista 5, Anexo D).

Apesar disso, foi observado que o sentido configurado ao objetivo da formação de uma escuta pensante pelos entrevistados se distingue do sentido de escuta estrutural proposto por Adorno (2011), segundo o qual:

[...] compreende-se aquilo que se apreende em sua necessidade, que decerto nunca é literalmente casual. O lugar dessa lógica é a técnica; para aquele que também pensa com o ouvido os elementos se tornam imediatamente atuantes como elementos técnicos, sendo que nas categorias técnicas se revela essencialmente, a interconexão de sentido (ADORNO, 2011, p.60).

O sentido de senso crítico apresentado pelos educadores foi referenciado pelas capacidades que se limitam ao reconhecimento técnico-estrutural estético da música, à interpretação das letras de músicas, a pensar sobre as sensações despertadas pelos alunos ouvintes e a fazer algumas associações perceptivas; não sendo evidenciada em nenhum momento a preocupação quanto ao desenvolvimento de percepções críticas quanto às relações de sentido e à consistência estética entre as partes e o todo da obra musical, entre forma e conteúdo, essência e aparência (ADORNO, 1993, 2005, 2011; COSTA, 2017), assim como também não foi identificada a preocupação quanto à contextualização histórica da música e quanto à reflexão sobre os possíveis aspectos sociológicos inerentes à formação musical, bem como sobre as possíveis implicações sociais e ideológicas da linguagem musical (ADORNO, 2011). O que demonstra, no trato com a música, ausência de considerações filosóficas sobre a arte, mais especificamente, no sentido de haver capacidades para se pensar a realidade, ou seja, de haver uma análise sociológica da música de modo a se pensar sobre a "[...] dinâmica histórica dos objetos, seu próprio "teor de verdade" (ALMEIDA, 2007, p.345). Tendo-se em vista essa compreensão da estética e da educação estética como proponentes da formação humana, segundo a leitura adorniana por Costa:

A necessidade da estética, mais especificamente da experiência estética, para a formação humana, se torna evidente para Adorno (2008a) quando se percebe o quão profundas são suas reflexões e críticas em relação a como o homem tem se posicionado diante da natureza e de outros, no que se refere ao domínio de condições para sua subsistência ou ao domínio social (ADORNO; 
HORKHEIMER, 1985). A estética se revela como algo necessário (ADORNO, 2008a). Por esse princípio, “[...] a necessidade da arte não é aceitar que a estética prescreva normas quando ela se encontra em causa, mas desenvolver na estética a força da reflexão que, por si só, dificilmente poderia levar a cabo" (ADORNO, 2008a, p. 517). A estética compreendida por essa via se configura como algo importante por dar condições ao indivíduo de refletir e criticar de forma consciente a obra e o contexto em que está inserida, sua essência. Conclui-se então a importância de uma Educação Estética, no que Adorno apresenta como fundamental para a formação humana (COSTA, 2017, p.135).

De maneira geral, percebeu-se um entendimento de ensino de música pautado centralmente na sua relação instrumental, alheia ao exercício reflexivo quanto à essência estilística da arte e quanto à formação de juízo fundamentado acerca da consistência de uma obra musical. Na verdade, foi identificado o predomínio de atividades que privilegiam a experimentação, a reprodução técnica e a improvisação musical, buscando-se, nessa musicalização, segundo um dos entrevistados:

[...] ensinar a marcação de compasso, a reconhecer e a tocar as notas, a usar a baqueta nas técnicas de baqueta, usa os teclados também para aprender a usar os dedos certos, muitas coisas. Mas o objetivo é bem simples assim: marcar o tempo, conseguir tocar no tempo e tocar uma escala de cinco notas, um pentacorde. E, em coisas bem simples assim acaba acontecendo coisas bem legais, uma sonoridade legal (B., professor de música, entrevista 2, Anexo D).

A relação com a música torna-se mecânica e, portanto, falsa: ela passa a ser um mero instrumento para a formação de um entendimento atômico pedagogicamente determinado por meio do reconhecimento fragmentário das melodias isoladas (ADORNO, 2005), em detrimento da liberdade para o envolvimento com a música, pelo interesse em conhecer aquilo que ela é, desviando-se da sua essência, reservada ao entendimento reflexivo e individual da sua estrutura formal, de seu todo harmonioso - no caso da música vívida, autêntica e que possui consistência, tal qual a boa música séria (ADORNO, 1986, 2005, 2011). O que compromete a experiência estética e, por sua vez, a formação cultural, recaindo à semicultura. Conforme Adorno:

A experiência - a continuidade da consciência em que perdura o ainda não existente e em que o exercício e a associação fundamentam uma tradição no indivíduo - fica substituída por um estado informativo pontual, intercambiável e efêmero, e que se sabe que ficará borrado no próximo instante por outras informações (ADORNO, 2005, p.15). 
Observou-se que a tentativa dos educadores de se aproximar do repertório musical, trazido pelos próprios alunos, possuía apenas a finalidade de aplicá-lo para ensinar música. Segundo alguns dos entrevistados, esses são utilizados como forma de se obter o envolvimento e o interesse dos alunos e para que, a partir disso, possam dissecar tais estruturas musicais a fim de que sejam apresentadas suas unidades estéticas mais básicas e, dessa forma, os alunos possam iniciar uma leitura de identificação musical, tal como se segue no trecho a seguir:

Então, a música mais simples que eles possam conhecer, dentro do ambiente deles - dentro da família, da comunidade -, a gente explica pra eles que essa música tem forma, que essa música tem cadência. Então, aproveita esses elementos para ensiná-los musicalmente, principalmente, para instigá-los para conhecer outras coisas, né. (A., coordenadora pedagógica, entrevista 1, Anexo D).

Mesmo havendo a afirmação de alguns dos entrevistados sobre o reconhecimento e a inclusão do repertório musical de seus alunos, foi observada, ao mesmo tempo, a sua depreciação estereotipada por parte daqueles, e esse se restringiu, na verdade, a uma estratégia de transição para novos repertórios musicais considerados mais elaborados pela equipe profissional responsável pelo projeto de educação musical; com exceção de um dos professores de música, que mostrou ao menos uma iniciativa de problematizar algumas das preferências musicais de seus alunos mais novos devido à incompatibilidade dos conteúdos de realidade apresentados, em algumas letras de música, com a capacidade de elaboração infantil pressuposta. Tal como se segue nas falas a seguir:

[...] a gente pensa também num estudo, num repertório entre aspas um pouco mais formal, mas que também é utilizado bastante pelas escolas de música que a gente vê por aí, ampliando repertório (A., coordenadora pedagógica, entrevista 1, Anexo D).

Quando a gente encontra um aluno que gosta disso [refere-se ao funk], a gente tenta entrar na dele e trabalhar junto no universo que ele está, a gente não exclui, né, mas eu sempre tento puxar a sardinha para o nosso lado, tento mostrar outras coisas, que eles não gostam porque, na verdade, não têm oportunidade, as coisas acontecem muito longe (B., professor de música, entrevista 2, Anexo D).

Hoje, lamentavelmente [...] já mudou muito, mas nos primeiros dias era bem complicado, porque os repertórios que vinham era sobre tragédia, era o repertório da realidade, nem vou falar que era repertório da realidade deles, é 
repertório que eles ouvem, que a família ouve. Ah, aí, tem o funk num sei lá das quantas, tem o da mulher que saiu com o cara... Músicas muito adultas, na verdade. A mulher que saiu com o cara e que se matou depois. É bem sinistro! Crianças pedindo para tocar isso! Aí, depois, a história do aborto. Não só o funk, mas principalmente o funk, entendeu. [...] De você cair o queixo, de você falar assim: "como eu vou fazer para sugerir algo diferente?". E algumas crianças até insistiam e eu quieto. Daí, 'você não vai tocar essa música?'. E eu tentando uma forma de não passar aquela música, porque... porque, 'ah, mas é a realidade', mas essa música não tá muito forte? 'Ah, mas a realidade é essa!'. 'Mas não é essa a realidade das coisas?' Estou falando de crianças de dez anos falando isso! Eu dizia: 'é uma realidade, mas será que a gente não pode construir uma realidade diferente? Então, se você está vendo tanta coisa ruim, vamos tirar um momento para a gente ver coisas mais bonitas? Basta de sofrimento, se a vida está tão sofrida, vamos achar um espaço pra gente sofrer menos e tornar a coisa mais divertida?'. E, aí, claro, partir para a seleção de um repertório bem definido, bem direcional, né, e que conquistasse eles pelo prazer de fazer as músicas. Alguns pelo desafio de uma música nova, de uma música em um outro idioma, muitas vezes, em inglês, ou em hebraico, cantos simples que são possíveis de serem feitos. E, aí, aos poucos, ir ganhando essa nova situação. E, hoje, graças a Deus, é possível trazer um repertório diferenciado (E., professor de música, entrevista 5, Anexo D).

O que nos levou a constatar que, nesse planejamento educacional, tanto não houve a organização de um estudo investigativo sobre o contexto social e psicológico do público atendido (ADORNO, 2006), muito menos a sua consideração objetiva - o que iria favorecer uma compreensão mais adequada quanto ao tipo de gosto musical de seus alunos a ser trabalhado e, por meio disso, poderia colaborar com a desconstrução das perspectivas estereotipadas dos próprios educadores acerca das comunidades periféricas e de seus alunos que lá residem - como já indicado anteriormente; como também, esses repertórios musicais deixaram de ser trabalhados e problematizados reflexivamente com seus alunos de modo que eles pudessem ser introduzidos ao exercício de reflexão, tanto sobre os seus estilos musicais preferidos (rap, funk e forró), quanto à possibilidade de ser iniciado o exercício da auto reflexão a respeito do próprio comportamento musical (ADORNO, 2011). O que indica uma educação musical dissociada da dimensão histórica (e, consequentemente, do próprio objeto), da compreensão das particularidades culturais de seus alunos e que está vinculada a uma noção conceitual limitada de consciência, enquanto capacidade formal de pensar (ADORNO, 2006; ADORNO; HORKHEIMER, 2006). O que contraria a perspectiva adorniana de uma educação para a formação do indivíduo autônomo. Para Adorno:

[...] aquilo que caracteriza propriamente a consciência é o pensar em relação à realidade, ao conteúdo - a relação entre as formas e estruturas de pensamento do 
sujeito e aquilo que este não é. Este sentido mais profundo de consciência ou faculdade de pensar não é apenas o desenvolvimento lógico formal, mas ele corresponde literalmente à capacidade de fazer experiências. Eu diria que pensar é o mesmo que fazer experiências intelectuais. Nesta medida e nos termos que procuramos expor, a educação para a experiência é idêntica à educação para a emancipação. (ADORNO, 2006, p.151).

Para Adorno, a compreensão de conhecimentos musicais, como de qualquer outro, não se limita à sua capacidade de apreensão pela identificação e reconhecimento das unidades estéticas, da abstração dos conceitos de estilos ou das considerações ontológicas sobre a música (ALMEIDA, 2007), mas se lançam à "[...] consideração sobre a obra singular e a história de formas [...]" (ALMEIDA, 2007, p.363). Nesta perspectiva, o conhecimento é a capacidade ativa do pensamento enquanto capacidade de relação e, assim sendo, é intrínseco à aptidão para a experiência estética musical e para a noção que compreende a sua mutabilidade e o seu dinamismo dialético histórico (COSTA, 2017). Ou seja, a educação estética que vise a formação de indivíduos pensantes não parte, ela própria, da adoção e replicação de conceitos atemporais e de classificações estilísticas nominalistas por momento histórico, uma vez que isso organiza antemão e de modo artificial uma percepção identitária do ouvinte, configurando um caráter definitivo e um núcleo imutável das estéticas, como também, o próprio curso histórico não se organiza em rupturas bruscas e acabadas entre um momento e outro (ADORNO, 1993).

Contrária a um sistema de ensino-aprendizagem, que se limita ao desenvolvimento das capacidades de reconhecimento e identificação musical, que se restrinja ao patamar de uma racionalidade genérica e que faz perdurar a coisificação humana, a educação estética para a formação cultural requer condições para que os alunos possam não somente apreender conteúdos teóricos formais e os mecanismos referentes às habilidades de tocar um instrumento musical, mas que, também, possam apropriar-se deles de modo a estabelecer relações de sentido e a tensionálos reflexivamente (ADORNO, 1995).

A experiência estética é o campo no qual os alunos poderiam compreender uma obra por ela mesma e não mediada por conceitos fechados, de modo a que se faria possível o início do desenvolvimento de uma consciência que compreenda os seus próprios antagonismos e a sua relação com o todo social. A arte enquanto práxis humana pode tanto expressar uma força criativa autêntica e ser, ao mesmo tempo, ideológica (ADORNO, 1993). À educação musical caberia, pois, a formação de uma escuta pensante no sentido de se ter no horizonte o 
desenvolvimento processual de uma lógica musical concreta e consciente quanto aos seus determinismos sociais e históricos imanentes à própria disposição técnica musical (ADORNO, 1993, 2011), de modo a vir a ser um campo de superação do domínio ideológico da indústria cultural pelo desenvolvimento formativo das capacidades crítica e reflexiva estética, tendo-se como uma das principais finalidades política-pedagógicas a formação de juízos estéticos bem fundamentados (ADORNO, 1995, 2006). Para os quais, a análise estética da arte, enquanto fenômeno social, e a crítica musical decorrente vêm a ser também crítica social.

A partir da consideração da perspectiva da Teoria Crítica, a dialética entre autonomia e dominação, inerente à dialética entre o particular e o universal, é campo de conhecimento e pensamento reflexivo indispensáveis para a formação de uma consciência crítica, a qual compreende os tensionamentos e ambivalências presentes nas relações humanas, políticas, culturais e sociais, como também em sua própria práxis decorrente. Diante disso, pensar em uma educação musical para a formação humana emancipatória implica o comprometimento com a filosofia da música enquanto pensamento crítico (ADORNO, 2006; ALMEIDA, 2007). O planejamento pedagógico, por sua vez, deve compreender a sua dialética e ter como objetivo a formação de uma consciência dialética. Para a qual é fundamental o julgamento estético musical embasado na análise da relação entre as unidades estéticas e o todo musical, isso devido a duas principais razões: primeiramente, porque "O que valida uma obra de arte é o modo com que os elementos se articulam dentro da estrutura musical" (COSTA, 2017, p.28); segundo, porque a arte, enquanto práxis, expressa a condição humana na sua relação com o todo social, sendo a sua própria condição diante das leis gerais sociais a mimese da dinâmica psicossocial da dominação sobre a autonomia, além de que a capacidade para a formulação de um juízo estético sobre a arte pode, também, vir a ser um entendimento crítico social (ADORNO, 1993). O que reforça a relevância da educação estética com o sentido e a finalidade de uma educação para a formação de uma consciência sensível e crítica e, assim sendo, para a emancipação e para a individuação, que, segundo Adorno (2006), trata-se do único caminho possível para a resistência objetiva contra o estado da dominação social mantido pela consciência reificada.

No tocante ao desenvolvimento de uma leitura reflexiva quanto à forma estética, essa infere no campo educativo musical a construção processual de uma análise dinâmica, a qual venha a compreender: 1) uma análise sobre a qualidade de articulação entre as suas partes e o todo musical, pautada na sua coerência de sentido, uma vez que a forma consiste na organização 
objetiva imagética dos conteúdos, ou assim o é em uma obra de arte (ADORNO, 1993); 2) uma análise sobre o tipo de relação estabelecida entre forma e conteúdo, ao que se refere à profundidade elaborativa estética dos conteúdos de verdade de uma obra (ADORNO, 1993), tendo-se que "A essência da obra de arte necessita da reflexão pelo caráter transgressor inerente a ela" (COSTA, 2017, p.27), em detrimento da dissociação entre conteúdo e forma e o consequente rebaixamento da consciência na música administrada e no seu fetichismo (ADORNO, 1975, 2005, 2011); e, por fim, 3) uma análise sociológica sobre os possíveis determinantes sociais e os mecanismos da razão dominante que organizam as produções musicais com as quais se tiveram contato, no que diz respeito ao tipo de lógica que a estrutura (ADORNO, 2004, 2011).

No entanto, como estamos a tratar propriamente da iniciação musical infantojuvenil, devemos nos voltar, primeiramente, às condições iniciais para uma educação musical emancipatória, ou seja, que favoreça a formação de ouvintes pensantes e, portanto, de indivíduos autônomos. A educação musical infantojuvenil, como etapa processual primária para a futura individuação e formação de pensamentos crítico, possivelmente e idealmente, quando no estágio de jovens adultos, para além da introdução reflexiva e historicamente contextualizada do conhecimento teórico e técnico formal, do ensino orientado pelo exercício perceptivo e da construção de relação de sentidos entre formas e conteúdos, deve expressar em seu planejamento a conscientização quanto às condições objetivas e sociais imanentes à aptidão da experiência estética: a relação entre sujeito e objeto e, assim sendo, a espontaneidade e a contemplação desinteressada do objeto pelas crianças e jovens mediante o processo educativo (ADORNO, 1993, 2006); como também, a introdução de um repertório musical que compreenda uma estética musical reflexiva, cuja unidade estética da aparência, da forma, corresponde e protege a interioridade da obra, a sua essência, na síntese estética de seus conteúdos de verdade, em detrimento ou em confronto analítico, por sua vez, da música padronizada destinada ao consumo, fechada à possibilidade do comportamento valorativo reflexivo, vinculada ao gosto atomizado e, por assim dizer, ao empobrecimento das capacidades críticas e reflexivas, estabelecendo-se, no lugar da relação, a sua fetichização (ADORNO, 1975, 2005, 2011). Isto porque já "Não podemos mais contar melancolicamente com a audição de uma sonata de Beethoven da sala ao lado, mas é preciso contar com a probabilidade de isto não ocorrer" (BECKER apud ADORNO, 2006, p.147). Na contramão, estamos diante de uma realidade social em que, sob o império ideológico da indústria cultural, "O comportamento valorativo tornou-se ficção para quem se vê cercado de 
mercadorias musicais padronizadas" (ADORNO, 1975, p.173). Além disso, a experiência estética deve ocorrer sem que seja determinada ou estipulada a priori, uma vez que recairá, contravia, no modus operandi da racionalidade administrativa e, consequentemente, comprometerá a profundidade da experiência musical dessas crianças e adolescentes (ADORNO, 2004, 2006).

A partir disso, a educação estética para a emancipação e para a formação cultural deve ter, como um dos seus objetivos fundamentais, o desenvolvimento da aptidão à experiência estética de modo a se contrapor à pseudoformação e à semicultura, no sentido de se opor a tudo aquilo que possa se interpor pedagogicamente e ideologicamente entre os alunos e aquilo a ser experimentado (ADORNO, 2006) e, deste modo, à própria organização social que impede a diferenciação do indivíduo no coletivo. Para Adorno, "a constituição da aptidão à experiência consistiria essencialmente na conscientização e, desta forma, na dissolução desses mecanismos de repressão e dessas formações reativas que deformam nas próprias pessoas sua aptidão à experiência" (ADORNO, 1995, p. 150 apud COSTA, 2017, p.137).

Isto posto, podemos refletir sobre a possibilidade desse confronto e o planejamento político-pedagógico objetivo para a efetivação de uma educação musical que possibilite experiências estéticas intelectuais mediante o tipo de racionalidade pedagógica empregada: o tipo de relação entre teoria e práxis educacional e a possível influência da racionalidade administrativa que revestem a relação com o método pedagógico adotado. Ou seja, requer pensar sobre o tipo de relação com o método pedagógico adotado pela equipe responsável pela organização do projeto de educação musical, de modo a se verificar, analiticamente, se esta consiste em uma relação verdadeira entre os sujeitos idealizadores do projeto e o método e que, assim sendo, caracteriza-se por uma conduta ativa e pensante sobre este último de modo a não se perder de vista o objeto, a educação musical para a emancipação e para a formação cultural; ou se a relação com o método é meramente uma falsa relação, caracterizada, por seu turno, pela reprodutibilidade técnica-administrativa.

De acordo com os entrevistados, a escolha do método T.E.C.L.A se deu pelo fato de este ser considerado o modelo pedagógico mais apropriado para se organizar o curso de música, de modo a corresponder idealmente com as finalidades e objetivos elencados. Entretanto, essa decisão não coube necessariamente a todos os profissionais envolvidos, ela foi definida a partir de uma consultoria externa e pela coordenadora pedagógica, sendo depois partilhada entre os demais. A opção por esse método também se deu pelo fato deste ser bastante referenciado nas 
pesquisas acadêmicas, o que dá indícios quanto à sua validade, que, de acordo com um dos entrevistados, ao relatar sobre alguns fatores dessa escolha:

[...] oferece uma estrutura bacana e ampliada pra você poder trabalhar, ele te leva a entender a construção da música, não só, tipo "pega e ensaia, vai lendo, sai rezando". Ninguém merece aquilo! [...] Eu entendo que essa metodologia, ela te leva a entender a parte teórica e a parte prática, pensando não só na construção musical, mas no entendimento da linguagem que é a música, que é você entender que é trabalhar com um material sonoro, que é você entender que essa música tem uma forma, que é você entender que ela também tem um caráter expressivo e entender que ela tem um valor para você" (E., professor de música, entrevista 5, Anexo D).

Diante da leitura reflexiva desses dados empíricos, é possível constatar a sua complexidade devido às contradições presentes na dinâmica desse projeto de educação musical (desde as formas de sua organização e a efetivação de sua práxis), tendo-se que, ao mesmo tempo em que há considerações essenciais quanto à finalidade de uma educação para a formação de uma consciência sensível, ainda é duvidosa a questão relativa à objetividade de sua práxis para o cumprimento daquela. Isto porque, dentro dos alcances investigativos da pesquisa de campo, foram observadas desiguais formas de apropriação reflexiva desse método pedagógico por diversos motivos, dentre eles, como já indicado, o tipo de formação dos profissionais entrevistados, a forma de divisão e estruturação das aulas, e o fator de influência dos determinantes exteriores em relação ao da própria análise reflexiva dos membros da equipe de direção, coordenação pedagógica e dos educadores.

Ao que se refere à questão da formação profissional, percebeu-se que os entrevistados que têm formação continuada e voltada à arte e à educação apresentaram descrições mais extensas e maior domínio reflexivo sobre o método adotado (no caso, os entrevistados A. e E.), enquanto que os demais apenas os descreveram de forma mais sucinta. A estruturação do curso de música com base no modelo de Swan Swanwick não se deu conjuntamente, sendo que o programa geral de aulas transversais (aulas de estruturação musical, aulas de prática de conjunto, teoria musical e teoria rítmica) foi organizado pela coordenadora pedagógica, enquanto a estruturação das aulas práticas instrumentais, por cada professor de música, correspondendo às suas especialidades; somado a isso, foi constatada pouca integração e planejamento conjunto da educação musical proposta pela equipe, que se expressou pela presença unívoca do método em questão e que, 
simultaneamente, gera uma sensação de liberdade de ensino dos educadores quando, na verdade, esta última está orientada pelos pressupostos conceituais e pelos conteúdos especializados fixados daquele a que pela relação entre sujeito educador e objeto música vinculada à relação entre teoria e práxis de forma que o educador possa pensar sobre a fenomenologia da música e da educação musical a partir da sua própria aptidão à experiência e, após isso, do seu próprio domínio teórico conceitual e, por meio deste, tensionar as contradições e fundamentar reflexivamente a sua práxis.

A valorização do método pedagógico, como uma entidade independente à reflexão do mesmo pelos responsáveis pelo planejamento desse projeto, converge com a tendência à burocratização e às práticas administrativas da educação, bem como com a alienação quanto a essas (ADORNO, 2004), expressando, pois, elementos constitutivos da própria racionalidade econômica e, devido à essa reprodutibilidade no campo do planejamento e da práxis educativa estética, a deformação da própria consciência crítica (ADORNO, 2006; ADORNO; HORKHEIMER, 2006), assemelhando-se ao todo social de modo que, conforme Adorno:

Un mecanismo representado según el modelo liberal no es meditado o penetrado ya por las administraciones, sino que éstas han adquirido tal sobrepeso frente a los ámbitos de libertad, que poco a poco éstos parecen sólo tolerados; algo que anticipó Karl Mannheim ya en la era del prefascismo (ADORNO, 2004, p.118).

O risco da predileção por um método pedagógico específico é o de sua reprodutibilidade técnica irrefletida, como se este fosse, ele próprio, uma autoridade especialista, cujo conhecimento, abarcado por esse, coisifica-se, sendo convertido ao valor de técnica produtiva. Por mais que esse apresente conteúdos relevantes ao desenvolvimento de uma consciência sensível, estes se enrijecem quando na ausência da relação ativa do pensamento de quem o utiliza. Pode-se considerar que no caso de um método ser tomado por sinônimo de planejamento pedagógico e ser interposto administrativamente na relação entre sujeito e objeto, a educação musical com a finalidade para a formação humana e cultural já falhou, visto que ela própria é inapta à experiência e demonstra uma vinculação questionável entre teoria e prática (ADORNO, 1995, 2004, 2006).

Ao confiar a um método pedagógico invariante a tamanha responsabilidade do domínio teórico que fundamenta a práxis educativa musical, sem ao menos as necessárias ponderações quanto às circunstâncias sociais e momentâneas que o contextualizam na situação de sua 
aplicabilidade, essa última mais consistirá em uma aparente práxis teoricamente fundamentada a que de fato vem a ser, uma vez que "Isto tem a ver com o fato de que, neste contexto, a tradução da teoria para a prática não é tão direta como talvez esperássemos em termos estritamente sistemáticos" (BECKER apud ADORNO, 2006, p.152), sendo que o pensamento é fundamental e o pensar o pensamento (ADORNO, 2006), neste caso, mais ainda. Ademais, por mais que haja teoria, se a racionalidade pedagógica que a elege não se dá pela autonomia reflexiva, esta vem a ser, na verdade, expressão de uma irracionalidade pedagógica mediatizada por uma relação atomizada entre teoria e práxis, ou seja, é resultado de uma consciência coisificada. E que o planejamento pedagógico torna-se ele mesmo em uma pseudo-atividade (ADORNO, 1995), cuja práxis organizativa se distancia da relação com a teoria, em que o método é importante por si próprio, substituindo a própria relação entre o sujeito idealizador do projeto educacional e o objeto educação musical.

Essa contraditoriedade no campo da educação é produto e reflexo das condições sociais objetivas do mundo administrado, cujas competências burocráticas não são próprias apenas do plano econômico burguês mas se estendem "[...] entretanto del mismo modo que la administración misma dentro de la sociedad" (ADORNO, 2004, p.118) e que, assim sendo, seu imperativo racional ideológico se impõe e determina a pseudoformação, a consciência alienada e a massificação de todos os estratos humanos e criativos, inclusive, a própria cultura. Sua pseudoatividade resgata a sua racionalidade mecânica, que, sob as vestimentas da liberdade e do pensamento aparente, faz perdurarem as regulamentações, as etapas programadas, os procedimentos formais e as medidas de controle de produtividade, bem como a preocupação com a garantia de que um certo tipo de educação funcione de modo a se atingir os resultados estipulados (ADORNO, 1995, 2004). A instrumentalização da racionalidade pedagógica destitui a possibilidade de emancipação da própria educação, tal como segue a ordem de todas as coisas submetidas à dominação social e à sua razão operante. Conforme Adorno, "Na pseudo-atividade, assim como a revolução fictícia, a tendência objetiva da sociedade liga-se, sem fissuras, à involução subjetiva. Parodisticamente, a história universal produz outra vez os tipos de homens de que necessita" (ADORNO, 1995, p.218).

O evidenciamento do método sobre qualquer possibilidade de relação entre sujeito e objeto infere também o predomínio da generalidade totalitária de um conhecimento prefigurado antemão sobre as especificidades sociais e psicológicas da população comunitária atendida pelo 
projeto social, configurando em uma pedagogia de modo inverso à própria contingência relacional da arte, da cultura e da educação estética enquanto campos de força que se opõem à dominação e ao ajustamento social pelo seu caráter de potencialidade emancipatória (ADORNO, 1993, 2004, 2006), ou melhor dizendo, contrária ao próprio sentido de individuação, finalidade da educação para a formação emancipatória (ADORNO, 2006).

Diante disso, pelo campo de análise da esfera da sociologia da educação, pode-se constatar que as caras reflexões críticas de Adorno são válidas ainda hoje. A especificidade dos dados empíricos coletados expressam uma dimensão particular pouco diferenciada do todo social determinado: a convalescência do espírito humano criativo, a conversão das forças criativas singulares e autônomas em forças produtivas e a decadência do pensamento crítico, inclusive nas próprias esferas das potencialidades humanas e emancipatórias, resultado da uniformização e massificação da psicologia das unidades singulares pela indústria cultural e pela racionalidade administrativa (ADORNO, 2004, 2006; ADORNO; HORKHEIMER, 2006). Tal como é explanado analiticamente por Adorno a partir de sua leitura de Weber quanto aos desdobramentos soberanos e planificadores da racionalidade tecnológica-administrativa e da heteronomia do pensamento especializado:

[...] dice Weber que la posesión de patentes educativas reprime de forma creciente el don - el carisma -; <<pues los costes "intelectuales" de las patentes educativas son siempre pequeños y no crecen, sino que decrecen con la masificación>>. Según lo cual se va privando al espíritu mismo de forma creciente de esa determinación irracional, no demasiado planificadora, que le es propia de acuerdo con el punto de vista tradicional. Weber destaca esto en un excurso: <<Detrás de todas las consideraciones del presente relativas a los fundamentos del sistema educativo se halla en algún punto decisivo la lucha del tipo especialista contra la vieja "humanidad da cultura", lucha que penetra en todas las cuestiones culturales por íntimas que éstas sean, y que está condicionada por la imparable propagación de la burocratización de todas las relaciones de dominio públicas y privadas y por la importancia siempre creciente del saber especializado>>. Weber se enfrenta aquí a la $<<$ humanidad especializada $>>$ en la forma en que era habitual en la sociedad del liberalismo tardío desde el Hedda Gabler de Ibsen. Resulta inseparable de ello, sin embargo, el aumento forzoso de competencias administrativas allí donde nos les corresponde objetivamente jurisdicción alguna. Los especialistas han de ejercer la autoridad en ámbitos en los que no pueden estar cualificados técnicamente, mientras que se precisa de su aptitud especial abstracto-técnico administrativa para que el mecanismo funcione y se mantenga en marcha (ADORNO, 2004, p.119). 
No contexto da sociedade contemporânea, a educação para a emancipação e, por assim dizer, para a individualidade, no entanto, não é um pressuposto evidente, muito menos, vem a ser uma tarefa fácil, tendo-se que ainda hoje “[...] existe uma ampla carência de possibilidades sociais de individuação, porque as possibilidades sociais mais reais, ou seja, os processos de trabalho, já não exigem mais as propriedades especificamente individuais" (ADORNO, 2006, p.152). O que, por sua vez, está diretamente associado à qualidade da práxis educacional, no sentido de ser uma práxis consistente quanto à objetividade e à consciência de seu planejamento. Que como resultado da falta de condições sociais para a expressão da força humana criativa e criadora, a pseudo-atividade, de acordo com Adorno:

[...] é provocada pelo estado das forças produtivas técnicas, estado que, ao mesmo tempo, a condena à ilusão. Assim como a personalização é um falso consolo diante do fato de que o indivíduo carece de importância no mecanismo anônimo, do mesmo modo a pseudo-atividade constitui um engano em relação à despotenciação de uma práxis que pressupõe um agente livre e autônomo, que já não mais existe. (ADORNO, 2006, p.218).

Como, então, educar para a individuação se nem os próprios indivíduos educadores não experimentaram a sua emancipação e nem tomaram consciência quanto à psicodinâmica social da dominação, da barbárie e da cultura administrada dentro do escopo da arte e da educação estética?

A objetividade da educação para a formação humana requer a formação da consciência esclarecida dos futuros educadores e demais responsáveis pela organização e planejamento dos conteúdos pedagógicos (ADORNO, 2006), o que significa também dizer das suas formas pedagógicas que possibilitem a liberdade, a espontaneidade, a afetividade, o envolvimento e a experiência estética. Isso requer, por sua vez, a conscientização quanto aos aspectos próprios da sociologia e da psicologia da educação, desde o âmbito das suas tendências históricas, transformações e reificações, como também, das suas particularidades contextuais de atuação. E, deste modo, segundo Costa:

É importante reforçar que para Adorno (1995a) um dos principais objetivos da educação é alcançar uma condição social que possa combater a barbárie. Por esse pensamento, qualquer prática educativa deve caminhar tendo esse princípio como direcionador. A estética, ou melhor, um processo de Educação Estética por meio da música pode alcançar esse objetivo se vislumbrar uma formação 
humana em que o sujeito possa desenvolver a sensibilidade e a crítica de modo a perceber a realidade como se apresenta para nela poder agir combatendo a dominação e a desumanização (COSTA, 2017, p.138).

Em se tratando da educação musical, mais especificamente, é preciso também avaliar o repertório musical proposto pelos educadores e coordenadores pedagógicos para o desenvolvimento da práxis educativa, como forma para se pensar o tipo de comportamento musical tido como referência para o aprendizado de seus alunos e para a sua respectiva formação perceptiva enquanto ouvinte. Como já referido, pouco foi verificado nas entrevistas e nas observações de campo um trabalho analítico reflexivo sobre a estética musical tanto do repertório proposto pela escola, como do próprio repertório musical trazido pelos alunos no sentido de se desenvolver um trabalho inicial para “[...] promover a autorreflexão crítica das relações sociais com o objetivo de modificá-las" (COSTA, 2017, p.138). Somado a isso, a escolha formalizada da música popular brasileira e internacional como repertório estético norteador da educação musical proposta é algo para ser problematizado, ainda mais com base na leitura crítica adorniana, por vezes muito dura, sobre o teor da música ligeira (ADORNO, 2011), a qual é resultado do declínio da música elevada, em decorrência da ascensão do poderio da racionalidade técnica-econômica e da indústria cultural, e expressão do rebaixamento das capacidades reflexivas e críticas, além da decorrente decadência do gosto musical (ADORNO, 1975).

A estética musical pode ser tanto uma expressão crítica e de negação social, como uma expressão destoada de sentido reflexivo. No primeiro caso, a crítica social pode advir tanto de uma obra de arte elevada, no que diz respeito à sua consistência estética (relação entre conteúdo e forma; aparência e essência; relação de autonomia e de sentido estruturado entre unidades estéticas e o todo musical, etc.), ao seu caráter imaginativo, ao pensamento estético que resguarda a interioridade da obra e, por assim dizer, os conteúdos de verdade, etc. (ADORNO, 1993), assim como pode ser uma manifestação estética imediata nos termos de função social do engagement (ADORNO, 1993). No segundo caso, o da música ligeira, a sua estruturação estética deformada pela racionalidade administrada, que transforma qualquer coisa em mercadoria, acaba por ser também uma crítica social, pois contém em sua produção estandardizada o mesmo mecanismo da esfera econômica de circulação e da indústria de confecção (ADORNO, 2011): a sua conversão em produto de diversão e consumo pré-fabricado; sua padronização, em que o hit vem a responder aos apelos comerciais; a aparência é seccionada de sua essência, tornando-se agente 
publicitário que ilude quanto à promessa do novo e do autêntico, mas que, na verdade, retorna ao "[...] triste prato de todos os dias" (ADORNO, 2011, p.91). O que retrata não mais a essência da arte, da sua autonomia e dos seus conteúdos de verdade, mas sim a própria essência do social: a banalização da experiência, do pensamento e da individualidade e, consequentemente, do prazer e da felicidade humana. Assim como Adorno, em seu texto O fetichismo na música, enfatiza:

Todavia, o que então se emancipa da lei formal não são mais impulsos produtivos que se opõem às convenções. $\mathrm{O}$ encanto, a subjetividade e a profanação - os velhos adversários da alienação coisificante - sucumbem precisamente a ela. Os tradicionais fermentos antimitológicos da música conjuram, na era do capitalismo, contra a liberdade, contra esta mesma liberdade que havia sido outrora a causa de sua proibição, devido às afinidades que os uniam a ela. Os porta-bandeiras da oposição ao esquema autoritário se transformam em testemunhas da autoridade ditatorial do sucesso comercial. $\mathrm{O}$ prazer do momento e da fachada de variedade transforma-se em pretexto para desobrigar o ouvinte de pensar no todo, cuja exigência está incluída na audição adequada e justa; sem grande oposição, o ouvinte se converte em simples comprador e consumidor passivo. Os momentos parciais já não exercem função crítica em relação ao todo pré-fabricado, mas suspendem a crítica que a autêntica globalidade estética exerce em relação aos males da sociedade. A unidade sintética é sacrificada aos momentos parciais que já não produzem nenhum outro momento próprio a não ser os codificados, e mostram-se condescendentes a estes últimos (ADORNO, 1975, p.176).

Diante da análise histórica e sociológica de Adorno (1975, 1986, 1993, 2011) quanto à regressão da estética musical reflexiva para a sua coisificação enquanto mercadoria e, simultaneamente, quanto ao enfraquecimento da consciência musical crítica e a sua alienação, que caracteriza a consciência musical contemporânea das massas, é preciso pensar em uma formação dos ouvintes dentro de um plano educacional que a tenha em conta, visto que o conhecimento teórico e crítico da sociologia da música também permitirá uma práxis consciente quanto ao tipo de trato com a música popular, bem como sobre os riscos do fetichismo na música.

Ao que diz respeito sobre o material empírico, até onde se pode constatar, a música popular referenciada foi caracterizada pelos entrevistados de forma positivada, a qual, em relação comparativa com o repertório musical dos seus alunos, foi por eles considerada "mais elaborada" no sentido correspondente ao aspecto musical referente ao seu aparente nível de complexidade e sofisticação, em detrimento da análise reflexiva estética quanto à consistência da relação entre forma e conteúdo, e quanto à qualidade de inter-relação de sentido entre os detalhes e a totalidade musical (ADORNO, 1986). O que leva a inferir uma relação acrítica quanto à sua 
estética e que, consequentemente, irá reverberar no próprio campo educativo e formativo do gosto musical dos seus alunos, comprometendo, por certo, um dos principais objetivos da educação para a emancipação: o juízo estético fundamentado e a autorreflexão (ADORNO, 2006, 2011). Ao invés da formação do gosto musical no sentido de uma elaboração musical, essa práxis educativa irá apenas aparentá-la, quando, na verdade, o desenvolvimento do gosto musical continuará a ser mediatizado pelo consumo e pelo entretenimento (ADORNO, 2011), mas, agora, por estilos musicais considerados mais elevados aparentemente, mas que - assim como aquele repertório musical considerados mais "simples", "vulgar" e "limitado" - também se caracterizam por sua estrutura estandardizada, tendo-se que, segundo Adorno, "Toda a estrutura da música popular é estandardizada, mesmo quando se busca desviar-se disso" (ADORNO, 1986, p.116).

Por outro lado, a educação musical que compreenda apenas música séria e, sobretudo, a música "pura", aquela que se aparta do uso verbal, e que "[...] orienta-se por critérios que se aproximam muito dos conhecimento: o lógico e o ilógico, o verdadeiro e o falso" (ADORNO, 1975, p.173), pode vir a ser tão ideológica quanto a que se efetiva por meio da música popular, uma vez que deixa de considerar a influência desta última na contemporaneidade, como também, pode desconsiderar a própria (pseudo)formação cultural inicial e a história de seus alunos enquanto indivíduos e, consequentemente, tanto a nega artificialmente tal qual o consumidor cultural - o tipo burguês "[...] frequentador de óperas e concertos", “[...] que é bem informado e coleciona discos" (ADORNO, 2011, p.63) e que busca forçosamente aparentar ser um expert -, como impede a necessidade da crítica social imanente à sua fenomenologia estética (ADORNO, 1986). Ademais, um projeto de educação musical que apenas compreenda um repertório musical clássico e, em especial, a boa música séria, não garante por si só a formação de uma escuta pensante, pois, para esta, a relação espontânea e direta, o envolvimento afetivo, a curiosidade, a experiência estética e a percepção estrutural são fundamentais (ADORNO, 2011).

A educação musical que apresenta como repertório musical a música popular, como é o caso da escola de música participante, infere uma planejamento pedagógico estético pouco apropriado de uma lógica musical concreta e um gosto musical, dos próprios idealizadores e educadores, comprometido quanto à sua capacidade reflexiva estética, cuja consciência quanto à estandardização, tanto da estrutura geral (forma) deste tipo de música quanto dos próprios detalhes (ADORNO, 1986), não parece ter sido estabelecida por eles. O que, possivelmente, deixará passar adiante, na própria formação do comportamento musical de seus alunos, tais 
esquematismos padronizados, acentuando o efeito de seu automatismo musical sobre o ouvinte: uma leitura perceptiva rudimentar e que pouco estabelece relações reflexivas entre as partes e o todo musical, já que pouco há relação de sentido entre eles, de modo que, para Adorno, como efeito primário dessa relação:

Sua captação do todo não reside na experiência viva dessa peça concreta de música que ele tenha acompanhado. O todo é preestabelecido e previamente aceito, antes mesmo de começar a real experiência da música; por isso, quase não parece influenciar a reação dos detalhes, exceto em conferir-lhes graus variados de ênfase (ADORNO, 1986, p.117).

Isso, por sua vez, se contrapõe à finalidade da formação do senso crítico, visto que a música popular é manipulada para o entorpecimento dos sentidos e, por isso, para o seu consumo como diversão e falso prazer (ADORNO, 1975); da mesma forma que a mesma, pelo seu esquematismo padronizado - caracterizado pela definição de estímulos que chamem a atenção do ouvinte e por fórmulas musicais de sucesso e, por assim ser, cristalizadas pela indústria manipula a audição dos ouvintes num contingente de reflexos condicionados, ou seja, “ [...] num sistema de mecanismos de resposta totalmente antagônico ao ideal de individualidade numa sociedade livre, liberal" (ADORNO, 1986, p.120). O ouvinte em formação é motivado, assim, pela percepção estética no sentido do reconhecimento dos modelos padronizados, por mais que estes se encontrem disfarçados em uma falsa complexidade estilística e que, ao mesmo tempo, gere a sensação de uma escuta pensante, ao invés do devido esforço reflexivo e crítico para tal. Segundo Adorno, sobre a música popular e a sua influência da formação do ouvinte:

Ela não somente dispensa o esforço do ouvinte para seguir o fluxo musical concreto, como lhe dá, de fato, modelos sob os quais qualquer coisa concreta ainda remanescente pode ser subsumida. A construção esquemática dita o modo como ele deve ouvir, enquanto torna, ao mesmo tempo, qualquer esforço no escutar desnecessário. A música popular é "pré-digerida", de um modo bastante similar à moda dos digest de material impresso (ADORNO, 1986, p.121).

A educação musical, que possui como repertório musical base a música popular para a experiência estética (se essa, assim também, for considerada como elemento fundamental para a formação da escuta estrutural), legitima a estandardização musical, cujo correspondente psicodinâmico, segundo Adorno (1986), é a pseudoindividuação , a qual contraria o princípio 
formativo da autonomia, da liberdade e da diferenciação. Tal como a estandardização, a pseudoindividuação é a expressão do ajustamento das unidades ao todo, do domínio do genérico e da indiferenciação sobre o particular, mas que são tidos ilusoriamente como algo novo e aparentemente original, pela falsa sensação de liberdade experimentada, cujos limites são impostos exteriormente pelo todo: na estandardização musical, a rigidez da estrutura musical padronizada delimita os intervalos de liberdade da capacidade estética dos detalhes, tal como acontece nas improvisações do jazz, que, de acordo com Adorno (1986, p.123), os improvisos "[...] são confinados dentro das paredes do esquema harmônico e métrico"; do mesmo modo a pseudoindividuação, dinâmica psicossocial na qual a liberdade do indivíduo é uma falsa liberdade, sob a condição do mal-estar social, a renúncia objetivamente necessária para a autoconservação no coletivo social é apropriada com fins ao progresso da dominação não necessária - “[...] a decisão de perseguir apenas fins privados” (ADORNO; HORKHEIMER, 2006, p.128), tendo-se a não individuação como condição para a manutenção de sua irracionalidade, a qual passa a ser também a do indivíduo (ADORNO, 2004; CROCHIK, 2001). Segundo Adorno:

Por pseudo-individuação entendemos o envolvimento da produção cultural de massa com a auréola da livre-escolha ou do mercado aberto, na base da própria estandardização. A estandardização de hits musicais mantém os usuários enquadrados, por assim dizer escutando por eles. A pseudo-individuação, por sua vez, os mantém enquadrados, fazendo-os esquecer que o que eles escutam já é sempre escutado por eles, "pré-digerido" (ADORNO, 1986, p.123).

A ousadia e subversão criativa e imagética, possíveis pela possibilidade da autonomia reflexiva, são reprimidas socialmente pelos mecanismos ideológicos da indústria cultural há muito tempo, sendo substituídas pelo contentamento por um "prazer artístico" estimulatório, fictício e o encantamento passageiro pela novidade e pelas canções da moda, tão passageiro quanto o tempo da programação publicitária dos novos hits de sucesso que, na verdade, são sempre os mesmos (ADORNO, 1975, 1986, 2011; ADORNO; HORKHEIMER, 2006). A passagem para a consciência musical das massas retrata o processo sociológico e psicológico do esvaziamento do $\mathrm{Eu}$, devido ao empobrecimento das experiências estéticas e da falência da consciência crítica, e, por assim dizer, a crise da educação estética e a relação fragmentária (senão a sua cisão) entre teoria e práxis - em que o ensino musical passa a priorizar a prática e a 
ênfase sobre elementos técnicos musicais dissociados do necessário envolvimento reflexivo com a teoria musical (ADORNO, 2005; COSTA, 2007), a qual deveria compreender por certo a sociologia da música. E que, conforme foi asseverado por Adorno (1975, p.177), "O fascínio da canção da moda, do que é melodioso, e de todas as variantes da banalidade exerce a sua influência desde o período inicial da burguesia”.

A educação pode tanto exercer um papel de resistência objetiva ao estado da consciência massificada pela individuação, como pode sucumbir alienadamente aos domínios ideológicos da indústria cultural, ajustando-se à esta e reproduzindo a sua racionalidade em sua própria práxis formativa. No primeiro caso, de acordo com Costa:

[...] o processo educativo deve priorizar a consciência artística associando e tencionando teoria e prática em lugar de enquadrá-lo em uma modelagem. A defesa desse tipo de educação ressalta a importância do conteúdo musical estruturado, para além da prática por ela mesma, para que o indivíduo seja capaz de fazer relações entre a obra e o contexto no qual se insere (COSTA, 2017, p.139, 140).

No segundo caso, ao invés de se propor a uma formação verdadeiramente humana e cultural, a educação que se estrutura com a mesma racionalidade da administração econômica a reduz em um estado de mercadoria, passa a ser "[...] um mero instrumento a serviço da ordem existente" (ADORNO; HORKHEIMER, 2006, p.12). E que, em vez de superá-la através da reflexão e do pensamento esclarecedor, ao conscientizar-se quanto aos elementos responsáveis pela regressão da consciência crítica e, em decorrência, pela barbárie, este tipo de educação os incorpora nas mais diferentes dimensões de sua organização e de sua práxis, tratando-se, pois, do caminho inverso ao proposto por Adorno (2006): a integração se sobrepõe à emancipação; o fetichismo na música se impõe diante da mínima possibilidade real para um comportamento musical estruturado.

A educação estética, ao atribuir valores culturais à música ligeira, passa a ser uma ilusão compensatória das necessidades humanas, fomentando, com essa, a tendência para o desenvolvimento de uma escuta passiva e para o seu consumo (ADORNO, 1975; ADORNO; HORKHEIMER, 2006), corroborando, por fim, com a própria dominação, mesmo sem se ter tal intenção, sendo que "[...] limita-se a se alimentar com o que lhe é dado de cima" (ADORNO, 1975, p.177). O que evidencia a problemática de uma educação que coaduna com os efeitos que a 
música popular pode provar em seus ouvintes, tendo-se em vista que "[...] as propriedades estruturais e objetivas da música determinam, por certo, as reações dos ouvintes" (ADORNO, 2011, p.58) e, consequentemente, de acordo com Costa (2017, p.143), “[...] o risco de um processo de alienação do sujeito, por estar inserido em uma sociedade de mercado que tem se incumbido de manipular o comportamento".

Na contramão da educação estética, que se proponha à formação de um comportamento musical consciente, a educação musical que se vincula à música popular acaba por direcionar seus alunos à escuta de massa, ao gosto da indústria cultural, à escuta atomizada (ADORNO, 1975, 1986, 2011). Segundo Adorno:

O ouvinte é psicologicamente encorajado pela inexorável presença desses tipos a saltar o que lhe desgosta e a deter-se no que lhe agrada. A limitação inerente a essa escolha e a alternativa claramente delineada que ela contém acarretam padrões de comportamento do tipo gosto/não gosto (ADORNO, 1986, p.125).

Ao pensá-la a partir da tipologia de comportamentos musicais proposta por Adorno (2011), em seu texto Tipos de comportamento musical, essa educação mais corresponderia aos que já não há mais relação direta com a música, que não há a capacidade para se "[...] pensar a música em seu sentido propriamente dinâmico, como algo que se desenvolve livremente [...]" (ADORNO, 2011, p.74), ou mesmo, aos que tomam a música como mera projeção catártica ou como somente uma fonte de estímulo sensório - tais como, por exemplo, o ouvinte emocional, o ouvinte do ressentimento, o fã de jazz e o ouvinte de entretenimento. O que compromete o seu conteúdo ético do processo formativo, em decorrência de sua própria determinação social (ADORNO, 2006). Que na própria relação com a música popular, tanto seu planejamento como sua práxis serão orientadas pela tônica da identificação, do entretenimento e da diversão, refletindo a própria lógica de manipulação da indústria cultural e, assim sendo, faz embotar o constructo do pensamento estético, cujas capacidades reflexivas e críticas são contrárias à diversão, pois requer atenção, seriedade e esforço de apreender novas percepções por meio da experiência estética (ADORNO, 1993, 1975). Segundo Costa:

[...] se deve tratar a experiência estética como algo que proporcione uma relação estreita com a produção de conhecimento e de uma consciência verdadeira com relação ao que se está percebendo. Qualquer música sendo escutada com 
atenção, buscando compreender seu contexto, deixa de ser relaxante para instigar o ouvinte em busca do "novo" (COSTA, 2017, p.144).

Assim, para a experiência estética e para a formação de uma consciência musical verdadeira, a educação musical deve se valer de uma dinâmica vívida em todo o seu curso, de modo a propiciar a liberdade perceptiva, a contemplação desinteressada, o interesse pelas obras, a instigar o esforço de uma escuta atenta e séria tal como requer o conhecimento pelo pensamento. Para isso, também se faz necessária uma práxis motivada pela potência objetiva da teoria (ADORNO, 1995), bem como "[...] é preciso que a música seja vivida, proporcionando uma verdadeira experiência estética" (COSTA, 2017, p.147). O que, para tanto, requer a autorreflexão da própria práxis educativa para que, assim, não sucumba aos mecanismos ideológicos da dominação social e à administração imediata da cultura, mas que volte a resgatar a dialética da formação, o princípio da educação para a emancipação e, contíguo a isto, a possibilidade de formação cultural enquanto diferenciação.

Logo, a educação musical que se vale subjetivamente de conceitos isolados de arte, cultura e educação e da ilusão quanto à sua potencialidade emancipatória concedida pelos desígnios de uma verborragia repetida, sem compreendê-las criticamente em sua sociologia, bem como na subjetivação de seus elementos, os mesmos das leis gerais sociais, deixa de tomar consciência de si mesmo e, deste modo, segundo Adorno (2005, p.3), "A formação que se esquece disso, que descansa em si mesma e se absolutiza, acaba por se converter em semiformação".

\subsection{O papel do educador musical dentro do contexto de projetos sociais e a qualidade do planejamento político-pedagógico de suas propostas educativas}

Tendo em vista o contexto propositivo dos projetos socioeducativos culturais musicais, mais propriamente, a habilitação em música não é condição suficiente para a elaboração de propostas político-pedagógicas que garantam a experiência formativa por meio de uma educação musical, mas sim uma formação do educador que supere possíveis deformações profissionais no que se refere à ilusória conclusão de se bastar em uma atuação docente centralizada no ensino de conhecimentos técnicos-formais profissionalizantes e de reproduzir categoricamente normas e métodos já estipulados e consolidados - pela capacidade reflexiva de ir além por meio da autoconscientização do acadêmico-docente, e na qual se possa apreender o sentido e o potencial 
formativo das disciplinas e cursos assistidos (ADORNO, 2006). Como base sólida para uma educação emancipatória, e uma vez que cabe aos educadores tamanha responsabilidade do desenvolvimento intelectual e da consciência sensível de seus alunos, é indispensável a formação da consciência dos próprios educadores, tendo-se que "as chances para uma tal atuação são tanto mais favoráveis quanto mais conscientes forem eles próprios" (ADORNO, 2006, p.45). Isso exige deles árdua disposição para o caminho individual e institucional para a autocrítica e, por sua vez, para a formação de uma consciência esclarecida - caso contrário, "a própria falta de emancipação é convertida em ideologia" (ADORNO, 2006, p.35) - e, simultaneamente a isso, exige capacidade para se construir um sentido de educação musical que articule as suas diferentes dimensões de ensino-aprendizagem, conhecimentos teóricos-conceituais e prática instrumental com as diferentes formas de organização e estruturação de cada instituição educacional, com a compreensão crítica acerca dos mecanismos da (pseudo)formação e da semicultura, com a consciência elaborada quanto às condições de mediar o condicionamento social e adaptativo com a possibilidade objetiva para a experiência estética musical formativa. De acordo com a concepção de Figueiredo (2005), a formação profissional do educador musical, hoje, implica idealmente em uma busca de "equilíbrio" entre a formação musical, a formação pedagógica e, por fim, a dimensão sócio institucional, necessária no sentido de aproximar "os educandos daquilo que os mesmos encontrarão em suas atividades reais como educadores musicais nas escolas e em diversos espaços educativos" (FIGUEIREDO, 2005, p.22). Desse modo, uma formação que torne possível se debruçar e avançar sobre os diversos desafios e dificuldades concretas presentes no contexto da educação e da pseudoformação por meio de um conhecimento e de práticas de ensino-aprendizagem conscientes e consistentes (ADORNO, 2006). No caso do projeto social participante desta pesquisa, isso se infere, de modo geral, na dificuldade de articular planejadamente estratégias de enfrentamento frente às esferas-problemáticas relacionadas à trama educacional formativa sem que se recaia ao assistencialismo. Anterior à práxis docente pontual, especializada e interventiva, para a formulação de um projeto institucional, segundo Adorno (2006), é necessário o retorno para o espírito filosófico enquanto “autoconscientização viva do espírito" (p.55).

Mais especificamente no que se refere ao escopo de projetos sociais educativos que visam promover a inclusão social por meio de um trabalho educativo formativo, a realização efetiva dessa finalidade só é possível mediante a escolha adequada de seus meios, a começar pela 
experiência de inclusão social dentro dos seus próprios espaços e relações entre os educadores e alunos, sendo a forma de planejamento político-pedagógico um dos principais meios para que isso se dê de forma consistente.

Uma vez que usualmente defendem uma proposta de educação no sentido de se fazer valer e se reconhecer o direito das pessoas socialmente marginalizadas enquantos cidadãos de direito, como para a organização social comunitária para o enfrentamento de problemáticas locais cotidianas, para além de outros processos de auto-aprendizagem e aprendizagem coletiva, como a capacitação de habilidades técnicas e profissional de seus alunos para a entrada no mercado de trabalho (PERES et al., 2008; GOHN, 2009), tal como verificado na fala dos entrevistados desta pesquisa, cabe aos educadores um "papel ativo, propositivo e interativo" (GOHN, 2009, p.33), que compreenda a perspectiva comunitária, papel próprio do educador social. Essa desafiadora tarefa envolve no exercício do planejamento educacional formativo a importante consideração de que, conforme Gohn:

A escolha dos temas geradores dos trabalhos com uma comunidade não pode ser aleatória ou pré-selecionada e imposta do exterior para o grupo. Eles, temas, devem emergir de temáticas geradas no cotidiano daquele grupo, temáticas que tenham alguma ligação com a vida cotidiana, que considere a cultura local em termos de seu modo de vida, faixas etárias, grupos de gênero, nacionalidades, religiões e crenças, hábitos de consumo, práticas coletivas, divisão do trabalho no interior das famílias, relações de parentesco, vínculos sociais e redes de solidariedade construídos no local. Ou seja, todas as capacidades e potencialidades organizativas locais devem ser consideradas, resgatadas, acionadas. (GOHN, 2009, p. 33)

Para Adorno (2006), a educação para a emancipação e para a formação cultural requer uma prática docente cujo exercício se dê pela tentativa reflexiva e autocrítica permanente de modo a garantir a liberdade e certa autonomia em seu campo de trabalho e, decorrentemente, a subtrair uma dinâmica metodológica de ensino-aprendizagem, bem como os seus resultados esperados e fixados, estabelecida previamente por um conceito de esclarecimento, de ciência, heterônomo (ADORNO; HORKHEIMER, 2006) que desconsidera os próprios sujeitos participantes. Na atual conjuntura educacional, encontra-se ainda muito por fazer nisso. Tal como pensava este autor no momento histórico de sua análise: 
[...] que os futuros professores tenha uma luz quanto ao que eles próprios fazem, em vez de se manterem desprovidos de conceitos em relação à sua atividade. As limitações que, bem sei, se abatem sobre muitos, não são invariáveis. A autoreflexão e o esforço crítico são dotados por isso de uma possibilidade real, a qual seria precisamente o contrário daquela dedicação férrea pela qual a maioria se decidiu. Esta contraria a formação cultural e a filosofia, na medida em que de antemão é definida pela apropriação de algo previamente existente e válido, em que faltam o sujeito, o formando ele próprio, seu juízo, sua experiência, o substrato da liberdade (ADORNO, 2006, p.69).

À vista disso, o tipo de educação musical proposta e, inerente a isso, a qualidade de planejamento político-pedagógico vão depender também da qualidade da formação dos educadores e do comprometimento com a formação cultural de seus alunos, visto que são eles os mediadores diretos neste processo dentro do contexto escolar ou de outras instituições educacionais. Podem, assim, favorecer tanto uma relação de consumo musical, "reforçando os padrões musicais incentivados pela mídia [...]" (URIARTE, 2004, p.251, 252), como, por outro lado, ampliar e diversificar o repertório musical de seus alunos e assisti-los à formação de uma escuta na qual haja a formulação de julgamentos bem fundamentados tal como o bom ouvinte (ADORNO, 2011). Isso, por sua vez, de modo mais abrangente, revela que o papel do educador tanto pode contribuir para a manutenção da "atrofia da imaginação e da espontaneidade do consumidor cultural" (ADORNO; HORKHEIMER, 2006, p.104), como para a formação cultural. Para que isso seja concretamente viável, de acordo com Uriarte (2004, p.255), aos professores cabe "[...] estar cada vez mais atentos aos processos e às estratégias que levam à aprendizagem, e para ZABALZA (2004), somente a partir do conhecimento desses processos é que virá o aprimoramento, o ajustamento dos métodos de ensino". 


\section{CONSIDERAÇÕES FINAIS}

Por mais que as criações ou produções artísticas e culturais, bem como os projetos de educação estética da contemporaneidade, estejam sujeitos aos artificialismos e à perspicácia da indústria cultural e recaiam no estado reificado da cultura administrada, não podemos nos furtar quanto à existência de forças sociais e pessoais que se contraponham à dominação social mesmo estando sob a condição social de oprimidos: há movimentos e coletivos culturais, organizações comunitárias e projetos sociais envolvidos com a luta social e com projetos de educação para a democracia por meio de práticas artísticas interventivas e do ensino das diferentes modalidades artísticas, compreendendo a potencialidade política social da arte e da cultura pela tônica da crítica social como crítica à ideologia dominante e pelo sentido de formação cultural enquanto formação de indivíduos cidadãos e democráticos, cujos intentos aproximam-se, respectivamente, das ideias de luta por reconhecimento de Honneth (2003, 2013), da tentativa de enfrentamento e da desconstrução das relações sociais mediadas pela teoria de mônades de Adorno e Horkheimer (1973) (CROCHIK, 2001) e da educação emancipatória de Adorno (2006).

Sua práxis artística, educativa e cultural buscam contrariar o discurso dominante com criações que provocam pelo menos as instâncias mais superficiais dos estados reificados da consciência, que, ao trazer elementos novos de conhecimento pela via da arte e da cultura, no mínimo tensiona o campo de compreensão antes colonizado pela figura do herói montado e da pátria honrosa, não se conformando e nem se rendendo à totalidade homogeneizante da indústria cultural, mas sim, buscando criar, por meio da arte, condições para a experiência de uma “estrutura diversificada do poder social” (ADORNO; HORKHEIMER, 2006, p.107).

A arte e a cultura das e nas periferias, como se pode observar, estão intimamente atreladas a essa força de resistência, fazendo-se da arte um campo de luta para o reconhecimento da memória, da história de injustiças sociais, mas também de potências de seu repertório local, que, dentre a diversidade de relações estabelecidas com a estética, há uma força expressiva por meio da qual se apresenta e toca a vida. Desobediente à hierarquia social, com as forças que têm, com os conhecimentos e alienações, não se deixam vencidos e inertes em um conformismo desistente, marcham à frente da avenida, lutam pelo respeito social, pela estética que tensiona o estado acomodado, resgatando a memória e recontando a história com a sua própria voz: 
Brasil, meu nego

Deixa eu te contar

A história que a história não conta

$\mathrm{O}$ avesso do mesmo lugar

Na luta é que a gente se encontra

Brasil, meu dengo

Com versos que o livro apagou

Desde 1500, tem mais invasão do que descobrimento

Tem sangue retinto pisado

Atrás do herói emoldurado

Mulheres, tamoios, mulatos...

(GRES ESTAÇÃO PRIMEIRA DE MANGUEIRA, 2019)

Entretanto, para além disso, é importante pensar sobre o real alcance de suas práxis, bem como suas limitações, uma vez que se é a transformação social que se pretende que seja realmente efetiva. Cabe, assim, refletir sobre as diferentes esferas que compõem tais organizações sociais no contexto de periferias: as relações grupais, a qualidade das propostas interventivas e educativas, o tipo de relação estabelecida com a arte, etc.

Ao buscar compreendê-las a partir da consideração orientadora entre o todo e as unidades (entre as organizações sociais e o projeto social participante da pesquisa empírica) e da compreensão conceitual relativa ao sujeito e objeto e, inerente a esta, da teoria e práxis, foi verificada uma série de contradições nas práticas propostas. Muitas delas decorrentes da ausência de condições objetivas e sociais essenciais para uma transformação social objetiva - como foi evidenciado em todo esse trabalho de dissertação, por exemplo, elementos da dominação social, mecanismos da indústria cultural e aspectos da semicultura presentes em sua práxis -, sobretudo, no que diz respeito ao pensamento e à autocrítica sobre a própria práxis desenvolvida.

A implementação da educação musical por meio de projetos socioculturais, por sua vez, possui diversos desafios e falhas, a começar pela própria qualidade da formação dos educadores e de seu planejamento político-pedagógico, além do tipo de valor socialmente atribuído à música e ao tipo dominante de relação estabelecida com ela, bem como a reprodutibilidade alienada de ideias hegemônicas da lógica da dominação social no próprio pensamento educacional brasileiro. O predomínio da função de entretenimento e de lazer, contígua à relação de consumo, reduzindoa ao valor de produto cultural, deixa de lado a possibilidade para a experiência formativa e para o pensamento. Ou, então, no âmbito contextual dessas organizações, mais especificamente, onde o caráter político cultural da educação é evidenciada no discurso mas que, no entanto, muitas vezes, em seu próprio engajamento político por meio da educação e da arte, reproduz a ideia de uma 
pragmatismo operante, da semicultura e da pseudoformação, em que a embriaguez dos educadores e ativistas socioeducativos pelo anseio da cidadania e da transformação social para a concretização real da democracia - por uma sociedade justa, pela igualdade universal de direitos e pela autonomia do sujeito -, pode se antecipar e ocupar todo o espaço da sua práxis, comprometendo o conteúdo ético do processo formativo: o comprometimento com o próprio conhecimento e com a própria práxis, de modo a se desenvolver na realidade concreta "[...] uma figura de práxis possível mais elevada; sua descoberta necessita de reflexão teórica" (ADORNO, 1995, p.209).

A problemática da razão prática no contexto da educação, desarticulada do pensamento crítico (ou melhor, do exercício da crítica permanente), e semelhante à entoada das organizações sociais, apresenta pressupostos de um certo tipo de ingenuidade utópica, segundo a leitura crítica realizada por Adorno em Educação e emancipação:

[...] os efeitos negativos de um processo educacional pautado meramente numa estratégia de "esclarecimento" da consciência, sem levar na devida conta a forma social em que a educação se concretiza como apropriação de conhecimentos técnicos. Parafraseando Adorno no último parágrafo da Minima moralia, quanto mais a educação procura se fechar ao seu condicionamento social, tanto mais ela se converte em mera presa da situação social existente (ADORNO, 2006 apud MAAR, 2006, p.11).

O planejamento político-pedagógico não deve se reduzir a um método irrefletido, restrito ao ensino de um conjunto de técnicas e de um conhecimento especializado tão somente, mas deve compreender um entendimento crítico quanto ao papel da educação musical na formação cultural de seus alunos e alunas, “[...] preocupando-se com a coletividade, com o cotidiano e com os interesses ideológicos e políticos" (URIARTE, 2004, p.253, 254), uma vez que, ainda mais no contexto interventivo-propositivo de projetos sociais e das escolas regulares, "[...] projetos com ênfase na técnica podem algumas vezes atentar menos a objetivos sociais e de formação global [...]" (PENNA et al., 2010 apud PERES et al., 2018, p.68). Se é a transformação social que se quer atingir, enfrentando as forças produtoras de desigualdades sociais, preconceito e violação de direitos universais por meio da educação, deve-se, portanto, compreender criticamente a sua fenomenologia, de modo a ser campo de forças para a desbarbarização e, assim, de modo a não dar, contraditoriamente, continuidade "aos pressupostos sociais objetivos que geram o fascismo" (ADORNO, 2006, p.43), sendo que "é mais cômodo seguir a correnteza, ainda que declarando 
estar contra a correnteza" (ADORNO, 1995, p.208). Trata-se, pois, de uma educação pela qual se possa ser capaz de resistir à dominação social e à cultura administrada ao invés de reproduzi-las, de modo a deixar-se de ser totalmente submissa aos mecanismos da indústria cultural, que impedem o desenvolvimento intelectual e, por conseguinte, a sua autonomia, a sua liberdade e o processo de individuação, sem a qual, não existe humanidade.

Cabe pensar categoricamente a práxis interventiva e educativa-formativa na relação com a teoria de modo a se elaborar um planejamento político-pedagógico que fundamente de forma consistente e consciente a qualidade das práticas culturais interventivas e da educação das diferentes modalidades artísticas de modo a não se fechar aos desvarios da boa intenção e desatenta quanto à possibilidade de traços maníacos imanentes, contra a qual a autorreflexão contrapõe e rompe com "[...] a ação cega que tem seus fins fora de si, e o abandono da ingenuidade, como passagem para o humano" (ADORNO, 1995, p.206). É crucial, todavia, que essa relação com a teoria seja reflexiva. Deve haver, portanto, relação e experiência e não um mero uso pragmático, pois, se assim o for, mais uma vez se recairia, em falso, à lógica do mercado e à semicultura. Para isto, é emergente e "necessária uma educação dos educadores" (ADORNO, 2006, p.46), como também de todos os profissionais envolvidos na organização e planejamento político-pedagógico da educação, no sentido do resgate de uma auto-reflexão filosófica, em sua densidade e dificuldade reflexiva objetiva, enquanto autoconscientização crítica e viva de si mesmo para que, assim, seja factível a possibilidade de se produzir conhecimento e práticas conscientes, condições indispensáveis para a experiência formativa no campo do trabalho docente. Ou seja, no que se refere à formação do educador, em uma compreensão comprometida com a formação cultural, conforme Adorno (2006, p.56), “a filosofia pode ser lida como sendo o potencial de resistência por meio do próprio pensamento que o indivíduo opõe à apropriação parva de conhecimentos, inclusive as chamadas filosofias profissionais".

À educação cabe, portanto, o papel de gerir condições para a experiência formativa e, por meio dela, a possibilidade para a apropriação subjetiva da cultura e para o pensamento. Isso tudo dentro de uma estrutura social vigente na qual a ordem econômica do capital a domina e a determina, pela sua racionalidade estratégica de produção, impondo uma irracionalidade objetiva de seu funcionamento, sendo essa perpetuada pelos arroubos perspicazes da indústria cultural aparentando a sua racionalidade e pelo empobrecimento da experiência; por sua vez, "onde a 
experiência é bloqueada ou simplesmente já não existe, a práxis é danificada e, por isso, ansiada, desfigurada, desesperadamente supervalorizada. Assim, o chamado problema da práxis está entrelaçado com o do conhecimento" (ADORNO, 1995, p.204).

O desafio da educação para a emancipação é o desafio da reversão da crise social dentro da sociedade que enfraquece as possibilidades para a experiência intelectual, estética e formativa, para a formação da consciência e, assim sendo, para a formação de sujeitos emancipados (ADORNO, 2006); aquela, conforme Adorno (2006), é o caminho possível para o enfrentamento das realidades socialmente desiguais, da divisão de classes, da violência e opressão, ou seja, para a elaboração do fascismo que perdura na sociedade atual de modo que este não volte mais a se repetir.

O desafio, por assim dizer, é imenso, é a travessia do inferno de Dante, em seus círculos mais profundos de sofrimento e horror, e pelo doloroso reconhecimento que lhe é exigida, por meio do processo de (auto)consciência, no interior da sua própria constituição e da própria formação subjetiva dos idealizadores e envolvidos em projetos socioculturais e educativos, tendose em vista que a estruturação de perspectivas apolíticas e estereotipadas, bem como a perduração das mesmas, possui implicações políticas em sua práxis (ADORNO, 2006). Consiste, deste modo, no imenso desafio de romper gradualmente com a racionalidade administrativa e a irracionalidade objetiva geradora do fascismo. Uma comédia, talvez, muito longe do que vem a ser divino, em caminho pouco confesso da redenção da barbárie.

A transformação social não será objetiva se não antes tornar consciente a profundidade do agravo social, se não antes reconhecê-la em seus alcances danosos sociais e psíquicos, em seu lastro presente dentro das próprias práticas institucionais que buscam enfrentá-la. Que não caiamos inertes em sonhos ingênuos e em desvarios deslumbrados, manta que também encobre o espelho d'água do narcisismo coletivo e a consciência reificada, mas sim trabalhemos para uma possibilidade objetiva de sonhar, mediante o discernimento intelectual. O desejo pela transformação não é a transformação. Não nos rendamos ao tempo das nossas pressas e urgências por mudanças, pois o tempo da mudança é outro: o da história, o da constelação dos momentos, o da formação da consciência, o da desbarbarização e da emancipação dos sujeitos, um tempo desmedido e pouco linear, pois é mediado pela contradição entre tendências regressivas e emancipatórias. Não nos bastamos com as ilusões geradas, por ventura, com as nossas práticas de resistência, atentemo-nos antes a nós mesmos na necessidade incessante de pensá-las, 
compreendendo-se, pois, a pedagogia como uma forma de política cultural para a desconstrução da cultura massificada.

Cabe, portanto, às escolas a esperança objetiva para a transformação, ao mesmo tempo que, a partir delas, podemos pressupor que o mesmo se faz necessário para outros espaços educativos formativos destinados à elaboração de políticas culturais. Conforme Adorno, por fim:

[...] não se deve esquecer que a chave da transformação decisiva reside na sociedade e em sua relação com a escola. Contudo, neste plano, a escola não é apenas objeto. A minha geração vivenciou o retrocesso da humanidade à barbárie, em seu sentido literal, indescritível e verdadeiro. Esta é uma situação em que se revela o fracasso de todas aquelas configurações para as quais vale a escola. Enquanto a sociedade gerar a barbárie a partir de si mesma, a escola tem apenas condições mínimas de resistir a isto. Mas se a barbárie, a terrível sombra sobre a nossa existência, é justamente o contrário da formação cultural, então a desbarbarização das pessoas individualmente é muito importante. A desbarbarização da humanidade é o pressuposto imediato da sobrevivência. Este deve ser o objetivo da escola, por mais restritos que sejam seu alcance e suas possibilidades. E para isto ela precisa libertar-se dos tabus, sob cuja pressão se produz a barbárie. O pathos da escola hoje, a sua seriedade moral, está em que, no âmbito do existente, somente ela pode apontar para a desbarbarização da humanidade, na medida em que se conscientiza disto. Com barbárie não me refiro aos Beatles, embora o culto aos mesmos faça parte dela, mas sim ao extremismo: o preconceito delirante, a opressão, o genocídio e a tortura [...] $\mathrm{Na}$ situação mundial vigente, em que ao menos por hora não se vislumbram outras possibilidades mais abrangentes, é preciso contrapor-se à barbárie principalmente na escola (ADORNO, 2006, p.116, 117).

Os esforços críticos dos autores frankfurtianos e, em especial, Adorno e Horkheimer, dizem respeito a uma produção de conhecimento sustentada na proposta de um conceito de esclarecimento dialético e, inerente a isso, ao comprometimento ético desses autores para com o próprio conhecimento e, por conseguinte, para com a formação de uma consciência crítica, condição chave para a elaboração e superação da barbárie e de seu substrato, a consciência alienada. Apesar de as considerações reflexivas e críticas adornianas ressoarem como uma melancolia pessimista, aquelas, na verdade, não se rendem às defesas psíquicas de negação diante do horror do mundo administrado, mas sim persistem na afirmação quanto à necessidade da crítica permanente, sobretudo, no campo da educação política enquanto educação para a emancipação.

As questões aqui exploradas, reconhecidas e problematizadas possuem uma densidade fenomenológica muito maior do que esse estudo investigativo consegue dar conta, e apesar de, 
neste, se compartilhar os pesares críticos de autores da Escola de Frankfurt sobre a estrutura oculta sob todo o processo de (pseudo)formação social e cultural presente tanto na construção subjetiva quanto na práxis humanas e de apresentar analiticamente alguns fios emaranhados onde se encontram processos da "flagrante contradição na consciência" (ADORNO, 2006, p.35), causando ao leitor um possível desânimo e sentimento de impotência, há também, assim como para Adorno (2006, p.52), "mais amabilidade nessa indelicadeza do que numa atitude que comodamente passa ao largo daquilo que acaba obstruindo a consciência das pessoas as suas melhores possibilidades, nos termos em que tenho confiança que constituem o empenho de qualquer pessoa". 


\section{REFERÊNCIAS BIBLIOGRÁFICAS}

ADICHIE, C.N. O perigo da história única. In: TED Global. 2009. Vídeo, 18:40min.

ADORNO, T. Arte, sociedade e estética. In: Teoria estética. Lisboa: Edições 70, 1993, p.952, p.275-285.

. Cultura y administración. In: Escritos sociológicos I. Obra completa, 8. Madrid: Akal, 2004, p.114-136.

. Educação e emancipação. $4^{a}$.ed.. São Paulo: Paz e Terra, 2006. 185 p.

. O Fetichismo na Música e a Regressão da Audição. In: Os Pensadores XLVIII. São Paulo: Abril Cultural, 1975, p.173-200.

136.

Função.In: Introdução à sociologia da música. São Paulo: Editora Unesp, 2011, p.113p.85-112.

Música ligeira. In: Introdução à sociologia da música. São Paulo: Editora Unesp, 2011, p.202-229.

Notas marginais sobre teoria e práxis. In: Palavras e sinais. Petrópolis: Vozes, 1995.

. Prólogo. In: Introdução à sociologia da música. São Paulo: Editora Unesp, 2011, p.47-

54.

. Sobre a música popular. In: Sociologia. São Paulo: Editora Atica S.A, 1986, p.115-132.

Sobre la relación entre sociología y psicología. In: Escritos sociológicos I. Obra completa, 8. Madrid: Akal, 2004, p.39-78.

Teoria da semicultura. $1^{\text {a }}$ versão. Porto Velho: Editora Universidade Federal de Rondônia, 2005. 20p.

. Tipos de comportamento musical. In: Introdução à sociologia da música. São Paulo:

Editora Unesp, 2011, p.55-84.

ADORNO, T.; HORKHEIMER, M. O conceito de esclarecimento. In: . Dialética do esclarecimento. Rio de Janeiro: Zahar, 2006, p.17-46.

Excurso I: Ulisses ou mito e esclarecimento. In: Dialética do esclarecimento. Rio de Janeiro: Zahar, 2006, p.47-70.

Indivíduo. In.:__. Temas básicos da sociologia. São Paulo: Cultrix, 1973, p.45-60. 
A indústria cultural: o esclarecimento como mistificação das massas. In: . Dialética do esclarecimento. Rio de Janeiro: Zahar, 2006, p.99-138.

. Prefácio. In: . Dialética do esclarecimento. Rio de Janeiro: Zahar, 2006, p.11-16.

. Sociedade. In.: . Temas básicos da sociologia. São Paulo: Cultrix, 1973, p.25-44.

AGÊNCIA MURAL. Coletivos da zona sul de SP organizam 'Quebrada cultural'. Folha de S. Paulo, São Paulo, 22 nov. 2013. Mural. Disponível em: <https://mural.blogfolha.uol.com.br/2013/11/22/coletivos-de-cidade-ademar-e-pedreiraorganizam-quebrada-cultural/>. Primeiro acesso em: 15 jun. 2018.

ALMEIDA, J. Filosofia da música e crítica musical em Theodor Adorno. Discurso, 2007, n.37, p.343-364.

ALVES, C. O navio negreiro: tragédia no mar. São Paulo: Global editora. 2008. 27p.

ANDRADE, J.B. O homem que virou suco. Embrafilme, 1981. 1h37min.

BAYÔ, L. Voz negra. Música. 2017. 3min.43s. Disponível em: https://www.youtube.com/watch?v=rfAb6tmfOvQ>. Primeiro acesso em: 23 Out. 2018.

BENJAMIN, W. Crítica da violência --- crítica do poder. In: Documentos de cultura, documentos de barbárie: escritos escolhidos. São Paulo: Cultrix, 1986. p.160-175.

Experiência e pobreza. In: Magia e técnica, arte e política. São Paulo: Brasiliense, S.A., 1996. v.1. p. 114-119.

BOURDIEU, P. Compreender. In: A miséria do mundo. Petrópolis, RJ: Vozes, 1997, p.693713.

CAP - COLETIVOS CULTURAIS DE CIDADE ADEMAR E PEDREIRA. Estéticas da perifa. São Paulo: 13 set, 2014. Vídeo on-line. Disponível em:

<https://www.youtube.com/watch?v=ddpG3RDV-Vk>. Primeiro acesso em: 18 jun. 2018.

COOPERIFA. A arte da inclusão. Acesso em vídeo. 2012.

COSTA, C.A. Educação, estética e formação musical. In: . Educação estética, música e formação humana: contradições da cultura à luz da Teoria Crítica adorniana. Tese de doutorado na área de Educação pela Universidade Federal de Goiás. Goiânia. 2017, p.124-148.

Experiência estética em música. In: Educação estética, música e formação humana: contradições da cultura à luz da Teoria Crítica adorniana. Tese de doutorado na área de Educação pela Universidade Federal de Goiás. Goiânia. 2017, p.17-51. 
. Introdução. In: __. Educação estética, música e formação humana: contradições da

cultura à luz da Teoria Crítica adorniana. Tese de doutorado na área de Educação pela

Universidade Federal de Goiás. Goiânia. 2017, p.11-16.

CROCHIK, J.L. A resistência e o conformismo da mônada psicológica. Psicologia Social, 13(2), p.18-33, jul.-dez. 2001.

DAYRELL, J. O rap e o funk na socialização da juventude. Educação e pesquisa, v.28, n.1, p.117-136, jan./jun. 2002. Disponível em: 〈http://www.scielo.br/pdf/ep/v28n1/11660.pdf $>$. Primeiro acesso em: 14 set. 2002.

FERNANDES, J.N. Normatização, estrutura e organização do ensino da música nas escolas de educação básica do Brasil: LDBEN/96, PCN e currículos oficiais em questão. Revista da ABEM. v.12, n.10, p.75-87, mar. 2004. Disponível em:

<http://abemeducacaomusical.com.br/revistas/revistaabem/index.php/revistaabem/article/view/3 65/294>. Primeiro acesso em: 30 mai. 2017.

FIGUEIREDO, S.L.F. Educação musical nos anos iniciais da escola: identidade e políticas educacionais. Revista da ABEM, v.13, n.12, p.21-29, 2005. Disponível em:

<http://www.abemeducacaomusical.com.br/revistas/revistaabem/index.php/revistaabem/article/v iew/331>. Primeiro acesso em: 24 mai. 2017.

FREUD, S. O mal-estar na civilização (1930). In: __. O mal-estar na civilização, novas conferências introdutórias à psicanálise e outros textos. São Paulo: Companhia das Letras, 2010, p.13-122.

GOHN, M.G. Educação não-formal, educador(a) social e projetos sociais de inclusão social. Meta: Avaliação, v.1, n.1, p.28-43, 2009.

GOHN, M.G. (Org.). Cenário geral: educação não formal - o que é e como se localiza no campo da cultura. In:__. Educação não formal no campo das artes. São Paulo: Cortez Editora, 2015, p.15-27.

A educação pela arte: o papel social desempenhado na formação do jovem. In:

Educação não formal no campo das artes. São Paulo: Cortez Editora, 2015, p.67-82.

G.R.E.S ESTAÇÃO PRIMEIRA DE MANGUEIRA. Enredo "História pra ninar gente grande". Sinopse 2019. Disponível em: 〈http://www.mangueira.com.br/carnaval-2019/enredo >. Primeiro acesso: 06 de Mar. de 2019.

HONNETH, A. Atualização sistemática: a estrutura das relações sociais de reconhecimento. In: . Luta por reconhecimento: gramática moral dos conflitos sociais. São Paulo: Editora 34, 2003. p115-224.

O eu no nós: reconhecimento como força motriz de grupos. In: Sociologias. Porto Alegre, ano 15, n³3, p.56-80, mai./ago. 2013. 
MARCUSE, H. Algumas implicações sociais da tecnologia moderna. In: . Tecnologia, guerra e fascismo. São Paulo: UNESP, 1999, p.73-104.

A conquista da consciência infeliz: dessublimação repressiva. In: A ideologia da sociedade industrial: o homem unidimensional. 4.ed. Rio de Janeiro: Zahar, 1982. p. 69-91.

MOVIMENTO CULTURAL DAS PERIFERIAS. Disponìvel em: <https://www.facebook.com/MovimentoCulturaldasPeriferias/>. Primeiro acesso em: 16 jun. 2018.

OSTETTO, L.E. Educação infantil e arte: sentidos e práticas possíveis. Acervo digital Univesp. 2011, p.1-14. Disponível em: <https://acervodigital.unesp.br/bitstream/123456789/320/1/01d14t01.pdf > Primeiro acesso em: 27 dez. 2016.

Professores de música nas escolas públicas de ensino fundamental e médio: uma ausência significativa. Revista da ABEM, v.10, n.7, p.7-19, 2002. Disponível em: <http://abemeducacaomusical.com.br/revistas/revistaabem/index.php/revistaabem/article/view/4 27>. Primeiro acesso em: 26 dez. 2016.

PENNA, M. Caminhos para a conquista de espaços para a música na escola: uma discussão em aberto. Revista da ABEM. v.16, n.19, p.57-64, mar. 2008. Disponível em:

<http://abemeducacaomusical.com.br/revistas/revistaabem/index.php/revistaabem/article/view/2 59/190>. Primeiro acesso em: 10 mar. 2017.

. A dupla dimensão da política educacional e a música na escola: I - analisando a legislação e termos normativos. Revista da ABEM, v.12, n.10, p.19-28, mar. 2004. Disponível em:

$<$ http://abemeducacaomusical.com.br/revistas/revistaabem/index.php/revistaabem/article/view/3 58/287>. Primeiro acesso em: 16 mar. 2017.

PERES, J. M. at. al. Resiliência e educação musical erudita: estudo em projeto social com jovens de periferia. Psicologia da Educação, São Paulo, v.46, p.61-70, $1^{\circ}$ sem. de 2018. Disponível em: <http://pepsic.bvsalud.org/pdf/psie/n46/n46a07.pdf>. Primeiro acesso em: 14 set. 2018.

PERIFERIA EM MOVIMENTO. Disponível em: <http://periferiaemmovimento.com.br/>. Primeiro acesso em: 15 jun. 2018.

PLATAFORMA SUCUPIRA. Disponível em: 〈https://sucupira.capes.gov.br/sucupira/>. Primeiro acesso em: 05 nov. 2018.

PREFEITURA DE SÃO PAULO. Centro de Geoprocessamento e Estatística (CGEO). Observatório social, 2012. Disponível em: <http://www.prefeitura.sp.gov.br/cidade/secretarias/assistencia_social/observatorio_social/mapas /index.php?p=2012 >. Primeiro acesso em: 11 jun. 2018. 
Dados demográficos dos distritos pertencentes às prefeituras regionais. São Paulo, 11 Jan. 2017. Disponível em: <http://www.prefeitura.sp.gov.br/cidade/secretarias/regionais/subprefeituras/dados_demograficos lindex.php? $\mathrm{p}=12758>$. Primeiro acesso em: 15 jun. 2018.

Mapa da vulnerabilidade social. In: __ . Portal da tranSParência. Disponível em: <http://transparencia.prefeitura.sp.gov.br/Paginas/Mapa-da-vulnerabilidade-social.aspx $>$. Primeiro acesso em: 11 jun. 2018.

Mapa: densidade de famílias beneficiárias de transferência de renda (PBF + PRC + PRM). São Paulo: Jul. 2017. 1 mapa, orientação e cor. Escala 1: 500.000. Disponível em: <http://www.prefeitura.sp.gov.br/cidade/secretarias/upload/assistencia_social/arquivos/TRANSF DE RENDA PBF PRM PRC Jul 2017Densidade.jpg >. Primeiro acesso em: 11 jun. 2018.

Mapa: distribuição dos beneficiários do BPC pessoa com deficiência. São Paulo: 2016. 1 mapa, forma, orientação e cor. Escala 1: 100.000. Disponível em: <http://www.prefeitura.sp.gov.br/cidade/secretarias/upload/assistencia_social/Distribuicao\%20do s\%20Beneficiarios\%20do\%20BPC\%20Pessoa\%20com\%20Deficiencia\%20-\%202016.jpeg >. Primeiro acesso em: 11 jun. 2018.

Mapa: distribuição dos beneficiários do BPC pessoa idosa. São Paulo: 2016. 1 mapa, forma, orientação e cor. Escala 1: 100.000. Disponível em: <http://www.prefeitura.sp.gov.br/cidade/secretarias/upload/assistencia_social/Mapa\%20Distribuicao\%20dos\%20Beneficiarios\%20do\%20BPC\%20Pessoa\%20Idosa,\%202016.jpeg >. Primeiro acesso em: 11 jun. 2018.

Programa de fomento à cultura da periferia de São Paulo. São Paulo: 09 Ago. 2016. Disponível em:

$<$ http://www.prefeitura.sp.gov.br/cidade/secretarias/cultura/cidadania_cultural/index.php?p=2040 3 $>$. Acesso em> 16 jun. 2018.

RÁDIO TAMBOR. Quebrada cultural zona sul - Coletivos da Cidade Ademar e Pedreira. São Paulo, 08 nov. 2013. Disponível em: <http://radiotambor.blogspot.com/2013/11/quebradacultural-zona-sul-coletivos-da.html>. Primeiro acesso em: 15 jun. 2018.

REDE NOSSA SÃO PAULO. Mapa da desigualdade. São Paulo: 2016. Disponível em: <https://www.nossasaopaulo.org.br/arqs/mapa-da-desigualdade-completo-2016.pdf?v=1>. Primeiro acesso em: 04 jul. 2018.

SÃO PAULO. Disponível em: 〈https://fumcad.prefeitura.sp.gov.br/forms/conheca.aspx > . Primeiro acesso em: 19 de Dezembro de 2018.

. Decreto de lei no 135, de 2015. Decreto de utilidade pública a ACC pela assembléia legislativa do Estado de São Paulo. 
SECRETARIA DE EDUCAÇÃO À DISTÂNCIA. Formação cultural de professores. Brasília: Ministério da Educação: Ano XX boletim 07, jun. 2010.

SP Cultura. Coletivo ArteFato. Disponível em:

〈http://spcultura.prefeitura.sp.gov.br/agente/1130/>. Primeiro acesso em: 16 jun. 2018.

TAKEUTI, N. M. Refazendo a margem pela arte e política. Nómadas, Bogotá, n.32, p.13-25, abr. de 2010. Disponível em: 〈https://dialnet.unirioja.es/servlet/articulo?codigo=5484359>. Primeiro acesso em: 09 de out. 2010.

TAYLOR, R. Radio Ga Ga. In: Queen. The works. Sony/ATV Music Publishing LLC. 1984.

TOMMASI, L. Culturas de periferia: entre o mercado, os dispositivos de gestão e o agir político. Política \& Sociedade, Florianópolis, v.12, n²3, p.11-34, Jan./Abr. de 2013. Disponível em: $<$ https://periodicos.ufsc.br/index.php/politica/article/view/2175-7984.2013v12n23p11/24752>. Primeiro acesso em: 09 out. 2018.

TENDLER, S. Utopia e barbárie. São Paulo. 2009. Documentário. Disponível em: <https://www.youtube.com/watch?v=cn9li_NePro $>$. Primeiro acesso em: 18 Jun. 2018.

TROTTA, F. C. O funk no Brasil contemporâneo: uma música que incomoda. Latin American Research Review, Pittsburgh, v.51, n.4, p.86-101, 2016. Disponível em: <https://searchproquest.ez67.periodicos.capes.gov.br/socabs/docview/1851704396/fulltextPDF/DDB6A85063 4B4F2BPQ/1 ?accountid=14643>. Primeiro acesso em: 09 out. de 2018.

VIOLA, P. Sinal fechado. (1970) In: HOLANDA, C.B. Sinal fechado. Philips Records, 1974.

ZOLTOWSKI, A. P. C. et al. Qualidade Metodológica das Revisões Sistemáticas em Periódicos de Psicologia Brasileiros. In: Psicologia: Teoria e Pesquisa. Brasília, Jan-Mar 2014,Vol. 30 n. 1, p. $97-104$. 
ANEXOS

ANEXO A - PORTAIS ELETRÔNICOS

\begin{tabular}{|c|c|c|c|c|c|c|c|c|c|c|}
\hline Palavras-chaves & \begin{tabular}{|l|} 
1. Educação \\
estética, \\
música, \\
formação \\
cultural, \\
Teoria crítica \\
\end{tabular} & $\begin{array}{l}\text { 1. Educação } \\
\text { estética AND } \\
\text { música AND } \\
\text { formação } \\
\text { cultural AND } \\
\text { Teoria crítica }\end{array}$ & $\begin{array}{l}\text { 2. Educação } \\
\text { musical AND } \\
\text { estética AND } \\
\text { formação } \\
\text { cultural }\end{array}$ & $\begin{array}{l}\text { 2. Educação } \\
\text { musical AND } \\
\text { estética AND } \\
\text { formação } \\
\text { cultural }\end{array}$ & $\begin{array}{l}\text { 3. Educação } \\
\text { AND música } \\
\text { AND } \\
\text { periferia }\end{array}$ & $\begin{array}{l}\text { 3. Educação } \\
\text { AND música } \\
\text { AND periferia }\end{array}$ & $\begin{array}{l}\text { 4. Educação } \\
\text { AND música } \\
\text { AND projeto } \\
\text { social } \\
\end{array}$ & $\begin{array}{l}\text { 4. Educação } \\
\text { AND música } \\
\text { AND projeto } \\
\text { social }\end{array}$ & $\begin{array}{l}\text { 5. Música } \\
\text { AND projeto } \\
\text { social AND } \\
\text { periferia }\end{array}$ & $\begin{array}{l}\text { 5. Música } \\
\text { AND } \\
\text { projeto } \\
\text { social AND } \\
\text { periferia } \\
\end{array}$ \\
\hline Base de Dados & PePSIC (0) & SciELO $(0)$ & PePSIC (0) & SciELO (1) & PePSIC (1) & SciELO (1) & PePSIC $\left(1^{\star}\right)$ & SciELO (1) & PePSIC (1*) & SciELO (0) \\
\hline Título & & & & \begin{tabular}{|c} 
\\
Música e \\
escola: um \\
diálogo com \\
a diversidade \\
\end{tabular} & $\begin{array}{l}\text { Resiliência } \\
\text { e educação } \\
\text { musical } \\
\text { erudita: } \\
\text { estudo em } \\
\text { projeto } \\
\text { social com } \\
\text { jovens da } \\
\text { periferia. } \\
\end{array}$ & \begin{tabular}{|l} 
\\
O rap e o \\
funk na \\
socialização \\
da \\
juventude.
\end{tabular} & $\begin{array}{l}\text { Resiliência } \\
\text { e educação } \\
\text { musical } \\
\text { erudita: } \\
\text { estudo em } \\
\text { projeto } \\
\text { social com } \\
\text { jovens da } \\
\text { periferia. } \\
\end{array}$ & \begin{tabular}{|l} 
Cantando \\
junto, por \\
saúde e \\
cidadania \\
no Acre: o \\
Canto Coral \\
do IFAC em \\
Sena \\
Madureira. \\
\end{tabular} & $\begin{array}{l}\text { Resiliência } \\
\text { e educação } \\
\text { musical } \\
\text { erudita: } \\
\text { estudo em } \\
\text { projeto } \\
\text { social com } \\
\text { jovens da } \\
\text { periferia. } \\
\end{array}$ & \\
\hline Tipo de material & & & & Artigo & Artigo & Artigo & Artigo & Artigo & Artigo & \\
\hline Ano de publicação & & & & 2004 & 2018 & 2002 & 2018 & 2015 & 2018 & \\
\hline Periódico & & & & Educar & $\begin{array}{c}\text { Psicologia } \\
\text { da } \\
\text { Educação }\end{array}$ & $\begin{array}{l}\text { Educação e } \\
\text { Pesquisa }\end{array}$ & $\begin{array}{l}\text { Psicologia } \\
\text { da } \\
\text { Educação* }\end{array}$ & Per Musi & $\begin{array}{c}\text { Psicologia } \\
\text { da } \\
\text { Educação* }\end{array}$ & \\
\hline Estrato & & & & $\mathrm{A} 1$ & B1 & $\mathrm{A} 1$ & $\mathrm{~A} 1$ & - & $\mathrm{A} 1$ & \\
\hline Área de conhecimento & & & & Educação & Psicologia & Educação & Psicologia* $^{*}$ & Música & Psicologia* & \\
\hline Data de acesso & $13 / 09 / 2018$ & $13 / 09 / 2018$ & $14 / 09 / 2018$ & $14 / 09 / 2018$ & $14 / 09 / 2018$ & $14 / 09 / 2018$ & $14 / 09 / 2018$ & $14 / 09 / 2018$ & $14 / 09 / 2018$ & $14 / 09 / 2018$ \\
\hline Link & & & & $\begin{array}{l}\frac{\text { http://www.sci }}{\text { elo.br/pdf/er/n }} \\
\underline{\text { 24/n24a13.pdf }}\end{array}$ & $\begin{array}{l}\frac{\text { http://pepsic }}{\text { bvsalud.org/ }} \\
\begin{array}{l}\text { pdf/psie/n46 } \\
\text { /n46a07.pdf }\end{array} \\
\end{array}$ & $\begin{array}{l}\frac{\text { http://nuww.s }}{\text { cielo.br/pdf/e }} \\
\text { p/v28n1/1166 } \\
0 \text {.pdf }\end{array}$ & - & $\begin{array}{l}\frac{\text { http://www.s }}{\text { cielo.br/sciel }} \\
\text { o.php?script } \\
\text { =sci_arttext } \\
\text { \&pid=S1517- } \\
\text { 7599201500 } \\
0200420 \& \text { alan } \\
\text { g=pt }\end{array}$ & - & \\
\hline
\end{tabular}


ANEXO B - BASE DE DADOS

\begin{tabular}{|c|c|c|c|}
\hline Palavras-chaves & $\begin{array}{l}\text { Educação AND Música AND Projeto social } \\
\text { AND Periferia }\end{array}$ & & \\
\hline Base de dados & Sociological Abstracts (58) & & \\
\hline Título & $\begin{array}{l}\text { O funk no Brasil contemporâneo: uma } \\
\text { música que incomoda }\end{array}$ & $\begin{array}{l}\text { Culturas de periferia: entre mercado, os dispositivos } \\
\text { de gestão e o agir politico. }\end{array}$ & \begin{tabular}{|l|} 
Refazendo a \\
margem pela \\
arte e politica
\end{tabular} \\
\hline Tipo de material & Artigo & Artigo & Artigo \\
\hline Ano de publicação & 2016 & 2013 & 2010 \\
\hline Periódico & Latin America Research Review & Política \& Sociedade & Nómadas \\
\hline Estrato & $\mathrm{A} 1$ & $\mathrm{~B} 1$ & $\mathrm{~B} 1$ \\
\hline Área de conhecimento & Ciências Sociais & Sociologia & Sociologia \\
\hline Data de acesso & 09.10 .2018 & 09.10 .2018 & 09.10 .2018 \\
\hline Link & $\begin{array}{l}\text { https://search- } \\
\text { proquest.ez67.periodicos.capes. gov. br/soca } \\
\text { bs/docview/1851704396/fulltextPDF/DDB6A } \\
\text { 850634B4F2BPQ/1?accountid=14643 }\end{array}$ & $\begin{array}{l}\text { https://periodicos.ufsc.br/index.php/politica/article/view/21 } \\
7 \text { 75-7984.2013v12n23p11/24752 }\end{array}$ & $\begin{array}{l}\frac{\text { https://dialnet.u }}{\text { nirioja.es/servlet }} \\
\frac{\text { /articulo? codigo }}{25484359} \\
=54\end{array}$ \\
\hline Observações & & & \\
\hline
\end{tabular}




\section{ANEXO C - ROTEIRO DE ENTREVISTAS}

\section{Compreensão conceitual de arte:}

1. Como o(a) senhor(a) definiria arte?

2. No que se refere à proposta institucional, como a arte é definida?

*Caso não apareça na fala livre do(a) entrevistado(a), buscar verificar os seguintes elementos: - caráter popular X caráter erudito;

- formação X indústria cultural;

- arte X entretenimento.

Práticas institucionais - Intenções e ideais institucionais e seus elementos constituidores:

1. Quais são os princípios e valores norteadores das práticas institucionais envolvidas com a formação musical das crianças?

2. O que visam promover com essa proposta de trabalho?

Desenvolvimento das práticas institucionais e o seu processo (auto)crítico:

1. Quais/quem são as principais referências e inspirações utilizadas pela equipe de educadores e coordenadores para fundamentar esse projeto de musicalização infantil?

(Ex.: autores teóricos; musicólogos; arte educadores; modelos pedagógicos, etc.)

2. Como se dá a criação, organização e preparo das atividades? Como elas são pensadas?

Práticas institucionais - o que se produz de fato:

1. Quais são as atividades desenvolvidas pela equipe do projeto? Como elas se dão?

2. Encontram/enfrentam algum tipo de dificuldade e/ou limitações para a realização da proposta de musicalização infantil dessa instituição/projeto?

- Em caso AFIRMATIVO, discorra sobre isso.

\section{Musicalização infantil e formação da criança:}

1. No trabalho desenvolvido pela instituição, o(a) senhor(a) identifica relação entre arte, imaginação e formação de consciência crítica da criança?

2. Ao seu ver, a musicalização infantil pode contribuir com a formação crítica e cidadã da criança? De que modo?

*Caso não apareça na fala livre do(a) entrevistado(a), buscar verificar os seguintes fatores:

- Noção de talento;

- carreira;

- hobby;

- importância pessoal (sentido, valor, etc.). 


\section{ANEXO D - ENTREVISTAS}

\section{ENTREVISTA 1}

Realizada em 21 de Março de 2018, São Paulo.

\section{A - Coordenadora pedagógica.}

Pesquisadora - Primeiramente, gostaria de saber um pouquinho sobre a sua formação e o seu papel aqui na ONG e no projeto da escola de música. Que se apresentasse um pouquinho..

A - Meu nome é A. Eu sou formada em Composição e Regência.. é, em Música, Composição e Regência; depois, eu fiz uma pós-graduação em Projetos Sociais e Culturais; me especializei em voz e hoje, eu faço mestrado na área de Fonoaudiologia em voz cantada. Aqui, na escola de música, eu sou a coordenadora pedagógica, né, toda a parte estrutural da pedagogia de ensino, eu coordeno junto com a equipe, né. Han.. A escola de música, não sei se você vai perguntar depois, é um projeto da ONG. E eu também dou aula aqui na escola da música, sou professora de canto e ajudo também na produção da banda.

Pesquisadora - Ok. Ah, é um papel fundamental, porque também meu roteiro vai perpassar pela questão do planejamento pedagógico mais a frente. Enfim, para apresentar um pouquinho mais desta pesquisa, eu busco investigar o processo de educação musical infantil e as possíveis contribuições para a formação cultural da criança, os desafios, enfim, dentro de instituições de cunho sociocultural, porque acho que já tem muita coisa a ser levantada no contexto escolar e, ai, meu interesse veio para instituições como a ONG. Então, para começar [INÍCIO DA AULA DE VIOLÃO NA SALA AO LADO - SONS DE CORDAS] na sua concepção, na sua formação, como que você definiria arte?

A - Olha, acho que a minha concepção já ta muito atrelada.. não sei se minha concepção é devida à minha formação ou, o que ta dentro do que, na verdade. Eu acredito, de verdade, que a arte é o respiro do existir, a arte é o respiro da humanidade. Acho que assim, todos nós temos situações na vida boas e muito ruins e que a gente tem a necessidade de se expressar, de se fazer valer, han.., de se emocionar, de a gente ter um caminho de fato que a gente possa, como posso te dizer.. se fazer presente mesmo...

Pesquisadora - Uhum..

A - Se fazer consciente, sabe. Acho que qualquer pessoa, em qualquer situação, precisa ter um canal de escape ou onde se possa identificar e aonde possa absorver aquilo que vê e equilibrar, acho que é isso. Acho que a arte equilibra a existência humana, né. Então, acho que ela é fundamental para todo mundo; por mais que alguém diga que não gosta muita de arte, eu acho que, de alguma maneira, ela ta envolvida com a arte, né. A arte, ela tem, por vezes, essa ligação com o belo - a gente sabe que ela não ta só nesta questão do belo, falando formalmente -, então, eu costumo dizer que a arte, assim como a música, que é o nosso caso aqui, é muito sem educação, né, no bom sentido.. que ela acaba atravessando a vida das pessoas..

Pesquisadora - Uhum...

A - Eu acho que é um ponto primoroso, de tamanho absurdo, importantíssimo.

Pesquisadora - E, ai, pegando carona quanto à questão da música, para dar continuidade para você introduzir a música no contexto da dimensão artística e estética, e pensando nesta instituição.. 
A - A música para mim tem um valor muito pontual, sou suspeita de dizer, ela ta na minha vida o tempo inteiro, né. É, eu acho que a música, talvez, seja uma das atividades artísticas, assim, mais presente, mais democrática na vida das pessoas, né. Ela interage com diversas artes, né: com a dança, com o cinema, é.. Então, assim, dar oportunidade para as pessoas fazer música, em se musicalizar, né, é elas se apropriarem de alguma coisa assim que tá diariamente no convívio delas. No nosso caso, aqui, que a gente está dentro do contexto de periferia, isso, para as crianças e para os adolescentes, tem uma importância, a gente percebe que tem uma importância muito grande.. porque o contexto musical deles é um tanto limitado. Que a gente entende que é muito importante porque é a cultura deles, né.

Pesquisadora - Um, uhum..

A - Então, tem sim uma importância, mas a partir do momento que eles experimentam outras coisas, conhecem outras canções, é.. é como se eles estivessem tendo a oportunidade de se projetar em outros lugares que eles num.. não tem acesso, né. E nesse processo, tem muitas identificações. É, falando mais pedagogicamente, a música, sem dúvida alguma, que é o nosso objetivo principal, mais que pensar em formar músicos profissionais e que possam despontarem na carreira, a gente pensa, sem dúvida alguma, em formar melhores pessoas, né. Que possam ter disciplina consigo, que possam saber andar em conjunto, que tenham paciência, que saibam escutar, né, e, isso, é uma coisa que a gente trabalha diariamente em todas as aulas e em todas as atividades. A música precisa, mais que precisa, ela tem essa disciplina, né. Então, assim, mesmo que subjetivamente, os alunos também estão absorvendo isso, sem dúvida alguma.

Pesquisadora - Bom, pensando, agora, no contexto da instituição, quanto à proposta de ensinoaprendizagem, como a arte é aqui concebida?

A - Aqui, na escola, a gente, nosso período de estada dessas crianças aqui é de um período de 3 anos, no mínimo - se as crianças são menores, obviamente que elas ficam mais tempo com a gente. E a gente tem como base a pedagogia de um pedagogo musical que chama Keith Swanwick, e a gente é baseado no método que no inglês é $\mathrm{C}(\mathrm{L}) \mathrm{A}(\mathrm{S}) \mathrm{P}$, uma sigla, e no português, é conhecido como T.E.C.L.A. É onde a gente trabalha com conceitos de Técnica, Execução, Composição, da Literatura e da Apreciação musical. Dentro deste viés, a questão da técnica, da execução e da composição, no caso, que a gente chama de criatividade e profienciação, são as coisas mais importantes, assim, um tripé que sustenta o restante, né.

Pesquisadora - Uhumm..

A - É, a gente valoriza o discurso dos próprios alunos, o contexto que eles estão sim, e ensina música a partir deles também. Então, a música mais simples que eles possam conhecer, dentro do ambiente deles - dentro da família, da comunidade -, a gente explica pra eles que essa música tem forma, que essa música tem cadência.. Então, aproveita esses elementos para ensiná-los musicalmente, principalmente, para instigá-los para conhecer outras coisas, né. E, ai, a partir disso, a gente pensa também num estudo, num repertório, entre aspas, um pouco mais formal, mas que também é utilizado bastante pelas escolas de música que a gente vê por aí, ampliando repertório. Daí, eles aprende a parte da teoria musical; eles aprendem um pouco da história da música; entram em contato com a parte da prática de conjunto. Principalmente, trabalhando essa questão do contexto onde eles estão, de novas possibilidades, principalmente, onde envolvem a música popular, que é o nosso foco aqui, e aonde eles possam criar, ser criativos. Que não seja uma coisa totalmente quadrada, que eles só aprendam a nota no pentagrama e que sejam reprodutores, máquinas, reprodutores daquilo que estão aprendendo.. Mas eles também são estimulados a criar, a improvisar.. Acho que essa é a nossa base. 
Pesquisadora - Bacana. Acho que você já trouxe coisas de perguntas que faria mais à frente. É.. pensando nos princípios e valores, né... acho que a questão acima já apresentou um pouco, mas gostaria de saber mais sobre os valores que considera centrais na ordem, na organização, no funcionamento da escola.

A - Formalmente, a escola é relativamente nova. A ONG já tem bastante tempo, hum.. a escola é um projeto da $\mathrm{ONG}$, né, a escola de música. E a gente tá, neste momento, de formalizar a questão dos nossos valores, da nossa visão. Mas, é implícito, desde o pensamento da ONG e da nossa dinâmica, aqui, alguns valores, assim, né. Que de fato são os direitos humanos básicos, né. Então, para gente é extremamente importante. Então, a escola zela por recursos que a gente não entende como recursos, é, "fúteis", né, digamos assim, mas que são recursos necessários para que as coisas acontecem. Então, questão de estrutura, tudo o que você vê aqui ao redor, ham, os instrumentos, os equipamentos, a sala, a higiene, ham... o direito de ter um espaço bacana para você ser inspirada, para ter um fruição interessante. Acho que isso é muito importante. É, a gente zela muito pela questão de ter um ambiente muito familiar, aqui: os alunos se cuidam muito...

[INTERRUPÇÃO/ENTRADA DA SECRETÁRIA DA ESCOLA]

A - Então, assim, a gente tem um ambiente muito familiar aqui, até porque a gente sabe que esse núcleo familiar dos alunos do nosso contexto é muito difícil, né. Então, do ponto de vista, de onde eles possam se cuidar, de amor e de amizade, isso é muito presente aqui.

Pesquisadora - Uhumm..

A - Ahnn.. Eu acho que os princípios básicos, sabe, de educação, de respeito, de parceria... isso é um viés extremamente importante para aqui, para a instituição e eles visam, sim, que os alunos consigam, han.. perdi a palavra.. que consigam se pontuar, se enxergar no mundo... de que eles possam ser autônomos de si, né, e, principalmente, propagadores do que eles aprenderam aqui dentro. Isso é uma coisa que é muito falado e que a gente já tem alunos, inclusive, que atuam nos grêmios da escola, levando atividade musical, planejando atividades culturais, né. Uma garota que começou aqui e que hoje está na faculdade de música e, como contrapartida, dá aula de musicalização na creche.. Então, isso, pra gente, é muito importante também: que eles consigam replicar e levar isso pro contexto deles, né.

Pesquisadora - Bem, e ai, uma pergunta que parece simples e que você já falou um pouco sobre, mas pensando mais focalmente a educação musical. Como, com esses princípios e valores, vocês vão trabalhando a formação, esse desenvolvimento das crianças e jovens. Além disso, vocês visam promover, com essa proposta de trabalho, outras coisas? Além de tudo isso, que você trouxe, que é tão importante.

A - Sim. Eu vejo sim os nossos diretores.. eles estão sempre, assim.. eles atuam muito com um olhar diferenciado para as crianças, na verdade, para cada uma delas, né. E, eles buscam juntos aos colaboradores, com os professores, a sempre buscar alternativas onde aquela característica daquele jovem, daquele adolescente, daquela criança possa ser cada vez mais usada na onde ele se destaca, né. Então, assim, eu acho que a maneira como eles podem se encaixar melhor no mundo e no caso, principalmente, assim, profissionalmente, onde eles possam, é, conseguir falar com todas as pessoas.. Isso é uma proposta muito grande que tem aqui na instituição. Então, assim, a gente tem casos mesmo, que aconteceram recentemente, de que um menino, que tá, assim, na fase da adolescência, se mostrou muito interessado, muito curioso em reforma de instrumentos e que eles estão o encaminhando em parceria com a luthieria para que ele possa, de repente.. quem sabe, tentar uma profissão. Então, esse olhar para cada característica para os nossos alunos, principalmente, para aqueles que acabam se destacando , que são super assíduos, que tão aqui.. Isso é uma coisa que acontece bastante, né. A gente dá condições para que todos 
possam se desenvolver, né, mas eu acredito que a gente possa tratar alguns casos diferentes como iguais. Há um carinho especial para isso. Uma outra questão, acho que está ligada à profissionalização. Talvez, han, num futuro próximo, da própria banda, sabe, que.. é.. aonde eles têm feito cada vez mais intercâmbios com artistas, trocas muito interessantes. É, acho que se posicionando mesmo, né, musicalmente, artisticamente, no mercado. Então, acho que, a partir do momento que você tem, quem tá afim de fazer no caso, muitas crianças estão afim de fazer, é, com recursos, com pessoas que estão aqui do lado para apoiar.. Acho que isso pode ser uma possibilidade bem importante.

Pesquisadora - Uhum. Bacana. Bom, além do modelo pedagógico que a instituição adotou pra organizar o planejamento pedagógico, é, como autores teóricos, há outras referências? Musicólogos, arte-educadores, e outros trabalhos, por exemplo?

A - Sim, sim. Acho que o trabalho do Swan é o que de fato dá um chão pra gente, mas, assim, a gente tá muito relacionado com o trabalho do Orff, com o trabalho do Kodály, que é muito utilizado aqui.. han.. Nós temos, no ano passado, o nosso grupo de voz, o coro, teve pela primeira vez no festival nacional de coros. E é uma influência muito grande um festival que acontece lá fora, que é regido pelo Werck Lack, de Indianopolis, Estados Unidos. Então, assim, são trabalhos importantes e de referência no meio musical.

Pesquisadora - Uhum.

A - É bem importante pra gente. E que se você for pegar e começar a esmiuçar cada um deles, você vai ver que dentro deles tem também, por exemplo, o trabalho do Swan que é transverso com o trabalho do Piaget..

Pesquisadora - Hummm!

A - É! Então, são trabalhos transversos com outros teóricos de linhas correlatas, né. Então, assim, teóricos e pesquisadores ligados, principalmente, o Orff, Kodály e o Swan que acho que são os que..

Pesquisadora - Caminham juntos com vocês..

A - Caminham juntos.

Pesquisadora - Ah, bacana! E, pensando, agora, o projeto político pedagógico e a equipe existente aqui, como se deu a criação desse projeto. Sei que a escola nasceu, está nascendo, está vindo da ONG, mas esse arranjo de equipe, é, desde a criação, a organização, o preparo das atividades, aqui da escola, né.. Pensar esse processo de musicalização infantil. Como se dá com a equipe de professores e os coordenadores?

A - É, a escola, ela começou, na verdade, de onde ela começou até onde nós estamos, dentro da ONG, já havia aulas de musicalização, tinha uma oficina ou outra acontecendo lá dentro. Começou com dois professores, né, o N. e a J. que estavam no momento aqui.. Han.. E, dentro deste projeto, surgiu a banda, e cada vez mais tinha crianças interessadas em fazer aula de música. E, num determinado momento, surgiu uma oportunidade através de uma bonificação por meio de um edital, e que eles não tiveram dúvida de ampliar o projeto e ter uma escola de música. Pesquisadora - Uhum.

A - Né, essa foi a colocação dos próprios professores que estavam aqui. Tá e agora, como é que a gente vai fazer isso? Não, a gente vai fazer uma escola de música! As coisas aconteceram de um jeito muito promissor e muito rápido a ponto de a gente chegar até este espaço físico e conseguirem apoiadores e patrocinadores, que a ONG é uma ONG suíça brasileira. Conseguiram patrocinadores lá de fora para que pudessem ter essa estrutura, né.. Os professores que estavam lá vieram pra cá e, daí, eles mesmo, naquela ocasião, organizaram de forma a abrir mais vagas e inscrições para a comunidade. 
Pesquisadora - Uhumm.

A - Então, eles fizeram, assim, de uma forma bem informal, avisaram no boca a boca que teriam mais vagas e foi, assim, uma surpresa muito grande, porque vieram muitas e muitas pessoas. Fizeram uma ficha simples e conversaram com as pessoas e começou o curso aqui. Na sequiência, eu cheguei, alguns meses depois, também para contribuir com as aulas de voz, principalmente, para as meninas que faziam parte da banda. E, em seguida, os diretores, o A. e a A., eles me fizeram o convite pra, de fato, estruturar a escola.

Pesquisadora - Formalmente?

A - Formalmente, como um programa, né. Enfim, eu ofereci pra eles.. eu entendi o contexto onde a gente estava, ofereci algumas alternativas e, ai, a partir daí, a gente começou um acerto mesmo com a equipe que estava, com novos profissionais que chegaram.. e a conversa foi, principal: olha, nós temos um período de 3 anos, né, que a gente considera razoável para se ter uma marca musical, digamos assim. O que nós gostaríamos que os alunos saíssem daqui, fazendo o que? Em que ponto que gostaríamos que eles saíssem daqui?

Pesquisadora - Uhumm

A - E, ai, neste momento, foi unânime que nós gostaríamos que eles tivessem uma base musical interessante e que eles pudessem, assim, buscar no mercado outras alternativas mais formais, se eles quisessem. No caso, um conservatório, ou um curso mais especializado e, de repente, uma faculdade de música.. A gente já até tem relatos assim.. mas que eles conseguissem falar uma linguagem universal da música ai fora, além de todos os valores que a gente falou, que já foi colocado aqui, são os principais de agregar pra eles, né.

Pesquisadora - Uhumm.

A - É, a gente entendeu assim que poderia ser uma coisa extremamente lúdica, han, e um pouco mais ligada à vertente social daquele critério "ah, a criança não tá na rua, já tá aqui, já tá muito bom", a gente não queria de maneira alguma para nesse lugar.. eu acredito que, hoje, poucas pessoas pensam dessa forma, graças a Deus. É, e a gente entendeu, então, vamos aproveitar esses 3 anos, sim, e vamos apresentar a música numa linguagem que eles possam falar com qualquer outra pessoa ai fora. É nesse nível que eles vão estar, né. E, ai, foi a partir disso que a gente foi construindo o programa. Então, é, hoje, cada professor, baseado nessa pedagogia, que eu já coloquei pra vocês, fez um programa de 3 anos pro seu instrumento, e a gente fez um programa geral para as aulas transversais, que são as aulas de estruturação musical, que todo mundo tem que fazer; as aulas de prática em grupo, todo mundo tem que fazer. E, ai, fora isso, cada professor de sua especialidade - tem professor de bateria, de guitarra, de baixo - estruturou seu curso, considerando o contexto, a faixa etária, a pedagogia que a gente tem aqui pra estabelecer o que vai acontecer aula a aula. Então, a gente tem um programa aqui de quase 200 folhas, é, do que os alunos têm a cumprir, digamos assim, durante esses 3 anos.

Pesquisadora - Uhuum.

A - Que, obviamente, a gente está sempre atrelado à formação, à roda de conversa, trocando sempre idéias para que seja adequado e que eles tenham espaço, inclusive, pra reformular e seguir outros caminhos, se eles acharem necessário.

Pesquisadora - E, ai, nesta organização, pensando nas atividades do programa.. se você puder apresentar o que a escola o Q.M oferece.

A - O Q.M oferece aula de violão, de guitarra, de baixo, bateria, de canto, de percussão, de flauta transversal, saxofone, clarinete, trombone e trompete e nós também temos... isso, assim, o aluno pode escolher uma aula de um instrumento principal, dessas que eu falei, e ele também vai fazer uma aula de instrumento complementar, né, no sentido mesmo que a gente pensa a música... que 
ela tem diversas gamas e elas se completam muito entre si. Então, por exemplo, um aluno que escolheu fazer aula de bateria, como instrumento principal, a gente indica que ele faça, como instrumento complementar, algum instrumento harmônico; então, ele pode escolher lá, por exemplo, voz, que é melódica, ou, então, o violão que é harmônico, para ele não ficar só na parte percussiva, né.

Pesquisadora - Hum, uhumm.

A - O aluno que faz aula de canto, ele pode escolher ou uma aula de percussão, ou uma aula de violão, por exemplo, que ele possa se auto acompanhar. Então, nós temos uma aula com um instrumento principal, uma aula de instrumento complementar. No primeiro semestre, ele tem uma aula que a gente chama - duas aulas, na verdade: uma aula de estruturação musical melódica e uma aula de estruturação musical rítmica. É, essa aula acontece em grupo e todos os alunos fazem e, ai, são momentos em que eles aprendem a música na prática. Então, eles cantam muito e, ai, a partir do que eles cantam, a gente vai nomeando, vai dizendo o que é fraseado, o que é cadência, deixando a música acontecer no corpo pra que, depois, a gente consiga no próximo semestre nomear mais as coisas. A mesma coisa acontece numa aula de estruturação rítmica, então, eles fazem muita prática de percussão corporal, han.., trabalham muito os ritmos com a movimentação, com até alguns passos de dança, que eles possam entender a rítmica bem na prática. Então, feita essa vivência no primeiro semestre, ai, no segundo semestre, o que acontece: a gente já entende que o aluno já adquiriu um pouquinho de experiência com o instrumento que ele escolheu, já adquiriu um pouquinho de musicalidade no corpo, promovidas por essas aulas em grupo; e ai, no segundo semestre, além de continuar com as duas aulas de instrumento que ele tem, ele vai fazer, ai sim, uma aula de teoria, né, que ai a gente consegue nomear melhor as coisas e mostrar a parte mais formal da música e também, ele vai fazer uma aula prática de conjunto, então, a gente faz pequenos grupos, onde eles podem atuar em conjunto. Então, canta junto com quem toca, né, junta com a bateria, com o violão.. A gente tem aqui, acho, 8 grupos ou 10 grupos de prática de conjunto, onde os alunos praticam música. Eles fazem música de verdade desde o segundo semestre, tá.

Pesquisadora - Uhum.

A - Além disso, a gente tem os coros também. Muitos desses alunos também fazem parte do coro. A gente tem o coro infantil e o coro de adolescentes

Pesquisadora - E, aqui, as atividades, elas são voltadas ao publico infantojuvenil, e quais são as faixas etárias contempladas?

A - Hoje, a gente atende, aqui, as crianças de 8 até 17 anos e 11 meses, né, até perto de fazer 18 anos. É... mas a gente também tem um programa que abre a escola, em uma parceria, pro coral de idosos. Então, nós recebemos aqui um coral da terceira idade, que também é muito bacana de fazer uma integração entre as gerações. É muito interessante.

Pesquisadora - É. E, dentro deste projeto, das atividades, é, e dentro do seu papel na escola de música, na instituição, quais são os principais desafios que você encontra no seu trabalho?

A - Olha, acho que, hoje, aqui.. talvez há num tempo trás, talvez, eu falaria outras questões, sabe, mas, hoje, bem na prática, eu acho que assim: influências de fatores externos que, digo, nem sei se "externo" é a palavra correta, porque é interno, está dentro deles, eles trazem consigo, é, que são, às vezes, as dificuldades deles estarem aqui fisicamente, inteiros, em todas as atividades, né, no sentido de que, às vezes, han.. é.. é.. problemas em casa - ora tem que cuidar do irmão; tem que cuidar da mãe que está doente -, a questão de ocorrências que acontecem fora daqui, alguns que moram um pouco mais distantes e não têm o dinheiro da condução pra estar.. É, acho que o desafio principal é tentar arquitetar de um jeito para que eles consigam frequentar isso aqui com 
uma certa paz. E, dentro do possível, até onde a nossa mão vai, a gente tenta dar um respaldo, né. Então, acho que esse é o principal desafio pra gente. Como que a gente pode diariamente estar construindo, han, com eles, soluções e, principalmente, de fazer eles entenderem que, sim, eles podem estar aqui, que eles podem abrir mão de uma coisa ou outra sem se sentirem culpados... é... Como a gente constrói esse caminho? Como que a gente viabilize isso junto com eles? Pesquisadora - Uhum.

A - Acho que esse é um super desafio, né, porque a gente acaba lidando com questões muito, muito maiores: com problemas familiares, com situações de violência, com situações de doenças, de saúde muito frágil, de precariedade.. e que, é.. não que a gente nunca quis fechar os olhos pra isso, né, mas, a gente entende que onde a gente está aqui é um ambiente muito diferenciado do que ao seu a redor. Qual que é a realidade deles? Então, acho que intermediar isso é um grande desafio pra gente. E, pessoalmente, isso tem sido um desafio muito grande.

Pesquisadora - Uhum. Fico bastante curiosa, de pensar a experiência de vocês, né, de como fazer esse intermédio uma coisa que é tão subjetivado na criança, né. Uma criança.. não sei, pois não vou chegar a conhecer, devido ao recorte da minha pesquisa, mas quem sabe.. essa questão de as crianças subjetivarem a não garantia de direitos. E, ai, um espaço que provê algum acesso a determinados direitos e fazer que esse encontro seja possível.

A - É. De fato, assim, uma coisa.. acho que têm os dois lados: muito difícil mas, ao mesmo tempo, muito prazeroso. Acho prazerosa quando a gente consegue promover esse encontro, essa experiência. Acho que é o sentido que faz a gente tá aqui, não tem como ser diferente. É, mas que, por vezes, a gente tem esses entraves; às vezes, muito pessoais, muito psicológico, e a gente não tem uma metodologia, um respaldo, a garantia para ir em lugares tão profundos além do que a gente tem feito. E, outras vezes, muito prático, assim, que, às vezes, poderia ser mais simples e acaba sendo mais profundo, né, porque é, às vezes, escolher o dinheiro entre ou ir pra escola ou vir a aula de música, por exemplo, né, ou...são situações muito complexas. Então, cada caso é um caso. A gente tenta olhar, como eu falei lá atrás, para cada situação, é... e tenta se solidarizar com isso e proporcionar aquilo que está na nossa mão. A gente entende que nem tudo está apto, e o que a gente faz é deixar esse ambiente cada vez mais favorável para que eles possam e queiram estar aqui, né. É.. questão mesmo de energia, de recebê-los, de estrutura.. Então, a gente tenta fazer isso com o maior carinho dentro do programa, a gente tem um programa interessante; dentro da possibilidade de levá-los para ver outras coisas, que a gente faz isso mensalmente, sabe, mais vezes no mês, de a gente circular com eles para que eles tenham um respiro, um mundo lá fora..

Pesquisadora - Uhum.

A - Isso é um grande desafio! Mas tão prazeroso quanto, como eu disse pra você. Eu acho que um outro desafio que eu tenho muito falado com os professores e com os colaboradores daqui, os educadores, está num sentido que eu sinto por vezes que as crianças, essa criança aqui, que a gente tem, de instituição, que faz aula de música.. ela acaba tendo, é.., duas visões assim muito fechadas e um buraco no meio. Essa é a sensação que eu tenho, né. Ou é um mundo difícil da casa dela ou do arredor dela, que, às vezes, é muito precário, onde moram doze pessoa num cômodo 3 por 3, ali, han.. vivendo situações muito difíceis e o mundo da instituição, vivendo aqui as coisas com uma certa organização, onde as coisas funcionam, onde alguns, no caso da ONG, se alimentam, têm as suas refeições, onde, às vezes, a gente até leva para ver um espetáculo que, por vezes, eles não imaginam, enfim.. Então, esse mundo assim: muito difícil, não tenho nada, e vou lá e as coisas acontecem e pode.. A gente sabe que lá fora, no mundo, na questão 
profissional, quando a gente se depara com a vida um pouco mais adulta, a gente entende que não é nem tão "pau, pau; pedra, pedra”, digamos assim, né.

Pesquisadora - Uhum.

A - Então, o que a gente tenta zelar aqui, bastante, é de como eles podem ter uma postura em relação ao mundo que não seja nem "nossa, ganhei um monte de coisas de mão beijada", né... A gente já teve uma vez um discurso aqui, uma vez não, na verdade, algumas vezes, entra um discurso aqui na escola: "Nossa, será que eles têm idéia de quanto custa uma aula de música?", né. Até que vem de fora mesmo: "Será que eles têm idéia de quanto custa uma aula de música?". Assim, acho que não é esse o discurso, não é essa a preocupação que a gente quer impor aqui. Que eles tenham a consciência e que eles estejam aqui, porque precisam valorizar isso, não é isso! É.. Mas essa ponte de saber como funciona o mundo real, a vida lá fora, como eles têm que valorizar cada momento da vida, independente se é aqui ou na casa deles, como eles vão reagir em relação a outros lugares que eles serão colocados, acho que esse é um desafio imenso também, né, pra gente. Acho que esse papel é do educador social, que não é só o do professor de música. É, ter uma super exigência por eles, porque a gente sabe que, né, alguns professores, por exemplo, que dão aula em conservatório e que sabem, que lá, pagam uma mensalidade absurda e o aluno está indo lá, de repente, pra ter uma aula muito parecida com o que a gente dá aqui; e, de repente, o aluno que está aqui não está compreendendo esta realidade! Né?! Acho que esse rigor de pensamento, acho que não tem como existir neste lugar, mas a conscientização de como é o mundo lá fora é um papel do educador social, não do professor de música. Então, tudo isso que eu quis dizer, acho que é um desafio também, perante aos colegas, aos conselhos, de olhar pra essa criança, assim, nesse papel de educador social e a gente está usando a música pra isso de forma que eles possam se apresentar para o mundo, de como eles podem se sentir melhores com o mundo lá fora, que eles possam seguir, que eles possam respeitar as pessoas, sem achar que o mundo ou é, digamos, a dificuldade que passo na minha casa, ou então, não, se não é a minha casa, sai de lá, tudo é muito bacana como é La na instituição. Então, é, isso também é um desafio pra gente.

Pesquisadora - Então, assim, para ver se eu compreendi, é.. pensando no contexto das instituições socioculturais em relação aos conservatórios ou a uma escola especializada ou profissionalizante em música, é pensar que, aqui, um professor de música tem também o papel de educador social?

A - Total.

Pesquisadora - E, então, para finalizar a nossa conversa, eu tenho mais uma questão para fazer, em especial para você. É, pensando o projeto de educação musical infantil nesse contexto, o processo de musicalização infantil, como você o percebe para a com a formação cultural da criança? Como que ela se abre, como se desdobra, se tem ou não uma contribuição para a formação cultural.. Acho que já ao longo da nossa conversa, muitas coisas já foram levantadas.. A - Olha, o que eu sinto, assim, que tudo aquilo que você traz pro corpo, tudo aquilo que você é fazedor, digamos assim, você se sente mais zen, você se apropria muito mais!

Pesquisadora - Uhum.

A - Acho que o fato de as crianças estudarem música, não só estudar, mas serem estimuladas a fazerem música o tempo inteiro, elas já ouvem música de um jeito diferente, elas têm um interesse de assistir música de um jeito diferente, elas têm curiosidades por outros tipos de música, elas já conseguem falar daquilo com um outro jeito, com uma outra fala, digamos assim, né. É, então, assim, tudo aquilo que você consegue deixar a criança imersa, tudo de estímulo que você consegue oferecer, ainda mais em algum período da vida que você consegue intensificar, de uma maneira preparada, com uma certa facilitação desse processo, eu acho que, han, essa 
abertura pra formação cultural na área artística já aconteceu, acho que já é parte, na verdade, né. Acho que mais que estar aberta pra fazer, acho que ela já é parte nisso que acontece, ela já interfere nisso dum outro jeito.

Pesquisadora - Uhum.

A - Acho que ela já toca de um outro jeito. A gente vê muito isso com os alunos daqui: as associações que eles fazem, os interesses que eles têm, as conexões que eles estabelecem entre eles, né.. as dificuldades que, às vezes, eles tinham de falar, alunos muito tímidos de conversar entre si, mas quando cada um pega seu instrumento, você vê um diálogo imenso acontecendo ali o tempo inteiro. Um diálogo familiar que você vê, por vezes, assim, a mãe que vai na escola e só ouve reclamação do filho que não tem comportamento, que não tira nota boa em matemática e de repente a mãe vê o filho no palco tocando e sendo aplaudido de pé, né, e ver o fillho cantar. Então, assim, não sei.. Desculpa.

[A ENTREVISTADA FICA EMOCIONADA, TURVA A VOZ E DEIXA CAIR ALGUMAS LÁGRIMAS]

A - Mas, acho que essa formação cultural está muito além. Acho que é a formação cultural deles mesmo, sabe..

Pesquisadora - Uhumm.

A - E de todo o entorno. Desculpa.

[CONTINUA COM A VOZ EMOCIONADA, CONTENDO O CHORO.]

[RISOS]

Pesquisadora - É, quem está nos bastidores tem outra visão, né.

A - É!

Pesquisadora - Outra compreensão..

A - Não sei, não sei.. não sei se isso veio ao encontro do que você precisava...

Pesquisadora - Veio muita coisa. Então, assim, para finalizar...

A - Desculpe.

Pesquisadora - Imagina. Muito bonito, muito bom que tenha vida, que tenha música e dentro dessas relações.

A - Pô! É importante ter.

Pesquisadora - E que bom, que você vem de coração no que você está fazendo.. E, ai, assim, para finalizar, eu queria que você contasse um pouquinho sobre esse movimento da banda. Ela já veio com a ONG e pelo que você falou, ela está encorpando, né, a banda está amadurecendo. E, eu gostaria que você me contasse um pouquinho sobre esse movimento da banda.

A - Bom, acho que, assim, a gente tem duas pessoas muito importantes pra falar sobre a banda: uma é o nosso próprio diretor, o A., ..., e a outra é o W., que foi o fundador, aqui, da banda. É, as crianças começaram muito pequenininhas nessa banda. O que o W. sem foi muito ousado no sentido de achar que as crianças poderiam tocar desde pequenininhos, sabe. Elementos muito básicos, mas para que elas pudessem tocar juntas. Isso é um valor muito grande da escola que a gente tem até hoje. As crianças foram crescendo, hoje, elas são adolescentes e o trabalho musical foi crescendo muito junto com elas. A banda tem também um aporte, sim, do professor W. com o professor L., de sopros, que também toca na banda.. Han, é uma banda que tem quase vinte integrantes. É, na ocasião, assim, de formação, nós tínhamos aqui a professora J., que também foi uma das criadoras da banda junto com o W., com um naipe de percussão muito forte, com as cantoras, onde se desenvolve-se músicas brasileiras, músicas do mundo e composições próprias. Então, nesse processo, a gente já teve a oportunidade de receber, inclusive, músicos de fora que 
vieram pra cá interagir com a banda. E, a gente entende que esse processo todo deles se verem nesse lugar onde a música não acontece de brincadeira, digamos assim, né.

Pesquisadora - Uhum.

A - Que eles estão se divertindo, mas que não é brincadeira. É uma coisa que a gente fala muito, que precisa se divertir muito para poder tocar, mas estar nesse lugar onde eles se dispuseram estar é um lugar onde eles estão conseguindo, assim, agregar muito valor, né, a ponte de fazer arranjos muito interessantes desses convidados; a estarem em palco de instituição formal de uma maneira mais profissional como foi lá no Sesc.

Pesquisadora - Uhum.

A - É, a gente entende que esse processo todo amadurece muito, muito, muito tudo aquilo que a gente desenvolve na escola e, principalmente, no sentido de eles se sentirem capazes, né: de falar em outras línguas; de se relacionarem com outros artistas; de poder agregar os familiares, que isso é muito importante, né.

Pesquisadora - Uhum.

A - A banda continua agregando muitos parceiros. A galera que vem ver a banda, os profissionais admiram muito o trabalho, é muito bacana que todos eles querem contribuir de alguma forma, né, então assim, tocar com a banda, com workshop, com formação. Isso é um lugar de muita semente.

Pesquisadora - Uhum.

A - A banda para os outros alunos na escola é muito admirada. Então, é, tanto assim, de se projetar: oh, eu posso estar lá um dia também, tocar na banda; ou de orgulho, de se orgulhar do

amigo que está ali. É, então, a gente entende que a banda é um cartão de visita da escola. É onde a gente consegue se comunicar rápido com as pessoas, né, através da nossa música. É, então, acho que é isso.

Pesquisadora - Ok. Agradeço pela entrevista.

A - Que isso! Desculpe pelas palavras atravessadas.

\section{ENTREVISTA 2}

Realizada em 21 de Março de 2018.

\section{B - Professor de música (violão, teclado, musicalização e prática de conjunto) e membro da banda dos/as alunos/as.}

Pesquisadora - Para começarmos, gostaria que você se apresentasse: seu nome, profissão, a sua ocupação aqui na escola de música.

B - Meu nome é B. Eu sou professor de música. Aqui, tenho alunos de 9 anos e tem jovens também, de até 19 anos. Ensino vários instrumentos. A minha formação é de violão erudito, eu estudei violão erudito na OLM, ai, depois, eu fiz faculdade de educação artística, né, e me formei em Artes. Desde então, trabalho com crianças, ensinando música.

Pesquisadora - Uhum. Em específico, o violão?

B - Sim, o violão. Mas, na verdade, eu comecei em 97 aqui no bairro em uma outra instituição, e lá não eram os instrumentos. Eu que criava, eu que construía os instrumentos de sucata, né. Lá não tinha recurso nenhum. E os instrumentos, a gente criava eles todos, né. De percussão; de 
instrumentos... alguns instrumentos, pesquisando timbre.. de sucata, frascos, tudo quanto era coisa que produzisse algum som, a gente usava na banda, né. Porque não tinha dinheiro, né. Pesquisadora - Uhum. E aqui nesta escola, você dá aula de quê?

B - Aqui, eu dou aula de violão, de musicalização, de teclado e também tem a participação na banda. Eu escrevo os arranjos para os sopros, faço esse trabalho na banda, e toco com eles.

Pesquisadora - Ah, eu ví uma foto, acho, no painel ali na entrada.

B - Ah, é muito bacana! Coisa que mais gosto de fazer é ficar com eles tocando. Mesmo os alunos, assim, que eu sento com eles para dar aula, assim, e acabo tocando junto, não resisto.

Pesquisadora - Interagindo. Legal. Então, para começar a nossa entrevista, eu queria saber um pouquinho sobre como você define o que é arte, do seu ponto de vista.

B - A arte, assim, serve como uma válvula para me livrar das tensões. Para mim, é isso, né; agora, eu vejo que para eles, é muito importante na socialização, até mesmo para que eles sejam pessoas mais corajosas. Eu trabalho bastante improviso na aula, então, essa coisas, acho que torna eles mais corajosos para fazerem as coisas; e também de encarar as pessoas, quer dizer, muitos são muito tímidos quando começam, depois, eles vão melhorando, vão conseguindo interagir mais com as pessoas, né.

Pesquisadora - Uhum. E, ai, você como papel da arte, no caso, a música, nesse papel de "desabrochar", digamos assim?

B - Isso. E acho que alivia muito as tensões deles, que eles têm histórias pesadas em casa e muitas vezes, eles fogem pra cá, né. Tem criança que vem prá cá no sábado e não quer ir embora mais, que chegam em casa e não tem nem espaço para ficar, né. Eles gostam muito de ficar aqui. Pesquisadora - Pensando a definição de arte no contexto da instituição, da escola, como você a apresentaria?

B - Aqui, no caso, a música tem aberto muitas portas para investimentos de pessoas que doam mesmo dinheiro, com recursos, doam instrumentos. Sempre é levado, é filmado algumas aulas, apresentações da banda.. Então, isso daí, ajuda muito a conseguir recurso para que cada vez mais a gente possa crescer mais e sempre melhorando as condições de instrumentos, de.. até mesmo de formação deles mesmo, né. Eles vão ver muitos shows. Então, isso é tudo recurso que vem de fora, né. A gente mesmo tem convênio com a prefeitura, mas não funciona muito, né, a verba da prefeitura, é muito pouca. Então, o pessoal daqui - o presidente e a presidente -, eles viajam muito procurando recurso pra conseguir manter o nível da escola. Você vê que o nível da escola é muito alto, aqui, de aparelhagem, de instrumentos, né, muito bom. Se você ver o estúdio...

Pesquisadora - Vi. Uma vez eu vi vocês ensaiando para uma apresentação que ia ter.

B - É uma coisa muito.. É uma coisa que eu nem sonhava quando eu vim pra cá. Nem imaginava que ia acontecer tudo isso, né. Quando eu comecei com a banda, eram instrumentos velhos que já tinham ai, e eles eram pequenininhos, e a gente nem imaginava que ia chegar nesse ponto. Pra mim, a minha vitória já foi conseguida há muito tempo. Eu estou aqui antes do início da escola! $\mathrm{Na}$ verdade, eu dava aula na ONG para os alunos. Antes, eles nem queriam, nem sabiam o que era música, não queriam fazer música, eram obrigados. Ae, essa coisa foi crescendo, eu formei a banda e eles começaram a se interessar, né. Ai, eu fui com um grupo forte que começou a tocar e também fez com que os outros se interessassem. Ai, depois, a gente entrou em um projeto com a prefeitura, compramos os instrumentos e estamos trabalhando aqui. Cada vez, crescendo mais aqui.

Pesquisadora - Legal. E, pensando as práticas da escola, quais são os princípios e valores que norteiam as práticas, as atividades que são realizadas aqui? 
B - Ah, a gente fala muito sobre o respeito com eles, do bom comportamento que o músico deve ter, de ter disciplina. Não é fácil ser músico. Tem que estudar muito. A gente fala sobre isso com eles. E a gente fala da relação que eles vão ter com o trabalho também, que o que eles aprenderem aqui, eles vão levar pro trabalho também. Esse respeito entre um músico e o outro. Nas aulas, quando eu comecei na ONG, uns ficavam rindo dos outros, né, quando erravam.. Então, isso aí a gente trabalha desde o princípio assim.. Respeitar a vida do outro. A gente trabalha isso daí. Na hora do solista, todo mundo tem que tocar mais... todo mundo tem que segurar a onda, tocar mais baixinho para que o solista apareça; aí, quando for a vez desse músico solar, aí os outros vão ter tocar mais baixo. Uns vão dando espaço para os outros, porque ninguém pode tomar todo espaço sozinho, porque a música é uma coisa de conjunto. A gente trabalha em conjunto. Então, é a coisa do respeito que a gente vem trabalhando, né.

Pesquisadora - Uhum.

B - O silêncio. Quando um aluno está com alguma dificuldade, que precisa ter aquele momento de silêncio para que aquela pessoa que está com dificuldade entende melhor. Então, tudo isso a gente trabalha. Mas acho que mais é o respeito que a gente trabalha.

Pesquisadora - Tá. E, dentro desse projeto que vocês têm de educação musical, o que vocês visam promover com essa proposta de trabalho?

B - A gente tem conseguido resultados na música assim... os meninos estão ficando muito bons! Mas não é por isso que a gente faz música, né. A gente quer que eles sejam bons cidadãos. Que eles cresçam e saibam respeitar os outros, que ajudem a construir uma sociedade melhor e não que, que a gente vê aqui muitos casos, que nesse bairro aqui é pesado. A gente vê muitos alunos que saíram daqui e estão perdidos por aí e estão pelas ruas.. Aqui, você não aprende coisa boa se estiver na rua. Aqui, então, é um refúgio muito forte que resguarda muito essa parte da criança e do adolescente. Aqui é um abrigo, uma proteção muito grande, a ONG.

Pesquisadora - Uhum. Entendi. E, agora, gostaria de saber com você, é, pensando o planejamento pedagógico do projeto de vocês. Quais são as principais referências e inspirações utilizadas pela equipe para estar desenvolvendo o projeto de musicalização? Seja autores teóricos, musicólogos, arteducadores, por exemplo.

B - A gente tem o Swanwick como modelo. A gente tenta seguir o método dele. Nas minhas aulas, também, a gente trabalha com os instrumentos Orff. Mas o que impera mesmo é o Swanwick.

Pesquisadora - E há outras referências? Músicos ou outros projetos de música?

B - Sim. A gente usa muito MPB com eles. Da Música Popular Brasileira, a gente tenta fazer com que eles conheçam pra que possam ter o próprio estilo deles, né. A gente tenta mostrar de tudo. Só algumas coisas da mídia mesmo que não dá pra engolir mesmo, mas.. Já quanto à cultura MPB, a gente explora tudo. E da música instrumental também.

Pesquisadora - Por exemplo.

B - Por exemplo, a gente os levou para um show do Pipoca, do Marco Lobo, com a Virgínia Rodrigues. Então, são bons cantores. A gente não leva, assim, eles pra ver show de funk, por exemplo. Eu não queria falar, mas tem que falar, né. Que é uma coisa que a gente não consegue aceitar. E é uma coisa que está muito forte, parece até que não tem como fugir disso. Não é uma música boa para se aprender.

Pesquisadora - E há um confronto, enquanto professor de música? Porque todo mundo tem seus universos e aí, aqui, você se depara com esse confronto?

B - Sim. Quando a gente encontra um aluno que gosta disso, a gente tenta entrar na dele e trabalhar junto no universo que ele está, a gente não exclui, né. Mas eu sempre tento trazer, puxar 
a sardinha para o nosso lado. Tenta mostrar outras coisas, que eles não gostam porque, na verdade, não têm oportunidade, as coisas acontecem muito longe. Daqui para a Vila Madalena, para ver um espetáculo legal, né.. Então, o que eles ouvem é isso daqui, o que toca nos carros e o que ouvem na internet também. Quando não tem alguém que vai conduzindo, ouve-se qualquer coisa mesmo. Mas a gente, aqui, a gente tenta levá-los para um caminho legal, musicalmente falando, né. Que eles possam aprender coisas legais.

Pesquisadora - Em relação às atividades realizadas na escola, como elas se dão aqui? Como se deu a criação, a organização e o preparo das atividades que vocês propõem aos alunos?

B - Naturalmente, assim. De acordo com a necessidade de cada aluno que vem. A gente vê para qual instrumento que ele daria, o que ele poderia tocar, o nível que ele está. A gente vai trabalhando conforme onde ele está, no nível que ele está, né. A gente não tentava interferir, fazer ele se encaixar no esquema; a gente tenta pegá-los no ponto onde eles estão e conduzi-los para fazer as atividades. Mas não tinha, assim.. Agora, com a A, que ela vem interferindo mais, mas antes só estava eu aqui, eu e o professor de trombone, tinha uma professora de canto, então.. Trabalhávamos mais instintivamente. Usávamos os métodos de instrumentos; métodos de violão. Usamos sempre métodos bons, né.

Pesquisadora - E, agora, na atual disposição da escola? Hoje, como vocês organizam e pensam as atividades?

B - Agora, sim, a gente tem um planejamento mensal, onde a gente determina os objetivos. Todo mês a gente faz o relatório. Na verdade, o planejamento, a gente faz todos os meses do ano e, depois, de acordo com o relatório, a gente vê o que a gente alcançou naquele mês, onde a gente chegou.

Pesquisadora - Isso por meio de reuniões?

B - Não, de escrita mesmo, né. Depois, quando tem reunião, a gente fala, mas não dá para fazer muita reunião, porque o movimento é bem.. a gente trabalha até de sábado com a banda. Às vezes, ainda, a gente sai da banda e vai ver uma apresentação. Porque, às vezes, a gente está à tarde no ensaio e depois "ah, depois, a gente vai ver um show do Marco Lobo", então, vai.. A gente fica sabendo na hora e vai. Toda vez que o A. sabe de um show legal e possam ir, já corre já; às vezes, até compram ingresso pra levar a gente, coisas assim. Eles investem em tudo aqui. Eu trabalhei em todas as instituições aqui do bairro.

Pesquisadora - Você é daqui?

B - Eu sou do bairro. Eu moro aqui.

Pesquisadora - É que eu sinto que você fala com bastante familiaridade, assim, da região.

B - É. Eu estou em casa, né. Eu brinco com eles que o mais interessado aqui sou eu, porque, aqui, é a minha casa, né.

Pesquisadora - Ah, legal! Legal.

B - Eu nunca quis sair daqui para morar em outros lugares. Era para eu trabalhar no Estado, "ah, vou trabalhar não". Vou ficar por aqui mesmo, aqui, eu sou mais livre pra tocar com eles, pra fazer o trabalho do jeito que eu gosto.

Pesquisadora - Uma coisa mais orgânica, né, mais fluida.

B - É. Eu trabalhava em uma escola particular lá em Suzano, mas, daí, não fiquei muito tempo não, Fiquei só dois anos. Não dá não, porque você não tem muito, assim, liberdade de criação.

Pesquisadora - Aqui, você sente mais essa possibilidade?

B - É. Aqui, tem muita possibilidade, muita liberdade de criação. A gente é muito livre para trabalhar. É como se eu estivesse na minha casa. 
Pesquisadora - Que bom. É, pensando no projeto da escola de música, eu sei que ainda é recente, né, que está se formalizando..

B - É. Sim. Na verdade, a gente ainda está se formando.

Pesquisadora - A escola de música nasceu há quanto tempo?

B - Há dois anos atrás. Com o projeto, o CAD, que a gente conseguiu ganhar a verba para esse projeto. O nome do projeto era "Cidadania através da arte musical". E que também, a gente tinha que formar uma banda, só que o grupo já estava meio assim encaminhado, né. Já vinha dando aula há dois anos antes e o pessoal já conhecia, mais ou menos, a criançada. E a gente já tinha essa proposta de montar essa banda. Ai, depois que estava tudo pronto, aí, o A. que é o presidente da instituição, chegou e falou "oh, vocês gostariam de continuar com o projeto como escola ou vocês vão fazer só o projeto e depois continua só com a banda?". Daí, a gente: "Não, vamos fazer a escola!". Aí, a gente.. ai, é loucura, né, porque a gente não sabia nada. A gente não tinha informação de administração para a escola. Aí, a gente foi, se enfiou de cabeça, ficamos todos embananados.. (risos) mas deu certo! Ai, a A chegou e organizou tudo. Graças a Deus!

Pesquisadora - Quais são as atividades daqui da escola?

B - As atividades? Ah, a gente tem coral para a terceira idade também; tem a musicalização de sete e oito anos, e de 9 e 10 anos; temos aula de contrabaixo, de guitarra; aula de sopro, clarinete, de sax, de trombone. São vários instrumentos aqui dentro. Tem bastante atividade.

Pesquisadora - E, pensando especificamente o processo de musicalização infantil, como que são essas aulas e demais atividades?

B - A gente trabalha com eles, é, usando muita improvisação também. Com os instrumentos espalhados. A gente começa a tocar e não sabe o que vai acontecer na aula, só a proposta de criar alguma coisa. Então, há muita liberdade de criação. A gente tem, como um dos objetivos, o de ensinar a marcação de compasso, mas nessa marcação de compasso, vai acontecer muitas coisas, né.

Pesquisadora - Tipo o quê?

B - Aprende a reconhecer e a tocar as notas; a usar a baqueta nas técnicas de baqueta; a gente usa os teclados também para aprender a usar os dedos certos, muitas coisas... Mas o objetivo é bem simples assim: marcar o tempo, conseguir tocar no tempo e tocar uma escala de cinco notas, um pentacorde. E, em coisas bem simples, assim, acaba acontecendo coisas bem legais, uma sonoridade legal. E eles vão se motivando com isso.

Pesquisadora - Nas suas aulas, em específico, você dá aula para as crianças também?

B - Tenho alunos de 9 a 10 anos também. Há alunos do ano passado que foram encaminhados para aprender a tocar flauta, porque, de repente, descobrem também as potencialidades deles. Instrumentos de sopro, né. Ano passado, eu usei bastante flauta doce, e descobri umas três crianças aí que tenho certeza que serão bons flautistas, né.

Pesquisadora - E como se deu essa apresentação do instrumento? É, as aulas de música para elas? B - Então, aprendendo mesmo com o instrumento na mão. Têm muitas flautas, que a gente dava nas mãos deles e praticava nota por nota, conhecendo o instrumento, com melodias fáceis, e o resto vai acontecendo, né. E no decorrer das aulas, você vai descobrindo que o aluno tem uma sensibilidade mais forte pra música e você vê que vai ser bom pra ele. Que ele tem uma musicalidade forte. Têm vários alunos aí que eu acho que vão ser bons instrumentistas, apesar de a gente não falar assim "ah, você vai ser músico e é só isso que interessa pra você". A gente tenta sempre mais criar a pessoa mesmo. Acho que aqui vai ser uma usina de músicos. Tem muita criança talentosa aqui, viu. Eu sei que deixa a gente, assim, bem animado.

Pesquisadora - E como você percebe esse talento, assim? 
B - Às vezes, tem aula, assim, que a gente fala "será que eles vão conseguir fazer isso?" e eles surpreendem a gente! Alguma melodia, assim, que você passa para eles e eles começam a tocar direitinho.. E a gente prepara a aula, mas não sabe onde vai parar, porque eles acabam tomando a liberdade e criando coisas que a gente nem imaginava! E a gente percebe o aluno tocando no tempo certinho, é, inventando algumas melodias legais, gostosas de ouvir. Agora, tocar no tempo é essencial, né, porque também tem crianças que não conseguem acertar no tempo, em que não têm coordenação. Isso aí desenvolve bastante a coordenação também.

Pesquisadora - É, para o desenvolvimento desse projeto, das aulas, enfim, dentro da sua experiência aqui, você encontra dificuldades, desafios para estar fazendo esse projeto de musicalização acontecer?

B - Aqui, na escola, não. Porque, aqui, vem mais as crianças que querem vir. Não são todas que vêm. Aqui, tem a ONG do lado, né, então, só as que querem vir mesmo que vêm pra cá. Tem muita criança que experimentou, aqui, e não gostou e não quer vir mais, então, não vem, né. Mas antes, era mais difícil, porque se pegava todo mundo, a sala de 25 alunos ali, e três ou quatro que queriam fazer, o resto só bagunçava e atrapalhava os que tinham vontade de fazer música. Que têm muito esses problemas de comportamento mesmo. Tem 120 crianças, né.

Pesquisadora - Aqui, hoje, tem quantas crianças e adolescentes?

B - Acho que mais de 100.

Pesquisadora - Para estar finalizando, agora.. Ao seu ver, a educação musical para as crianças e para os jovens, ela possui uma contribuição para a formação para elas enquanto indivíduo, para a formação cultural deles?

B - Sim. A educação musical fez muita falta nas escolas, né. Acho que foi em 71 que deixou de ser aplicada nas escolas, né. Dali pra cá, você não tem, assim, uma produção musical boa no Brasil. Tem os que têm possibilidade de estudar música e que conseguem produzir uma música boa e até reconhecida lá fora, mas a massa mesmo não conhece muito de música, né. Que eu acho que a produção musical no Brasil é resultado disso daí, que a música foi tirada das escolas, né. Agora, a música voltou a entrar no currículo escolar, ai, acho que daqui pra frente, acho que daqui uns vinte anos, essas pessoas que estão produzindo, vão começar a produzir música boa, né. E a música inclui mesmo como indivíduo. Muita gente consegue alguma coisa por intermédio da música. Eu mesmo sou muito tímido, se não fosse a música, eu estava dentro de uma caverna. Gosto de ficar sozinho, não gosto de ficar assim de movimento, de muita coisa, de me relacionar com as pessoas, assim..

Pesquisadora - E pensando na escola de música, você percebe na sua experiência com os alunos, nas aulas e nas demais atividades, essa contribuição?

B - Percebo no relacionamento entre eles, eles aprendem a conviver entre si. Aqui, tem muito disso assim, vem em um sábado, o pessoal do coral, que tem da manhã e da tarde, é, tem também o dos idosos.. daí, os adolescentes têm contato com os idosos, dai, é uma vivência ampla. Têm os da terceira idade, os pequenininhos de 7 a 8 anos de idade. Então, é uma coisa como se fosse uma família mesmo. Então, esse convívio é muito bom para eles. Então, aprendem a respeitar as diferenças. Tem adolescente, aqui, que estuda em escola particular e a criança que estuda na escola do Estado, tem essa convivência também. Tem muita amizade. Eles criaram muitos amigos aqui. É um espaço que acontece muito isso: amizade. Acho que é isso.

Pesquisadora - Ok. Acho que era isso.

\section{ENTREVISTA 3}


Realizada em 28 de Junho de 2018.

\section{C - Presidente}

Pesquisadora - Primeiramente, gostaria que você se apresentasse, falar um pouco sobre a sua formação e sobre o seu papel aqui. Sei que é um papel importante, pois junto com o seu esposo, você inauguraram, criaram, a ONG e a escola de música.

C - Isso. Eu sou a C. Eu sou advogada, sou formada também pela Universidade de São Paulo. Me casei logo após que me formei com o A. e fui morar na Suíça. Na Suíça, advoguei também, fiz os exames lá, enfim, advoguei, fui advogada na Suíça. Trabalhei como advogada por vinte anos. Paralelamente, enquanto ainda morávamos na Suíça, o A. havia feito um documentário aqui nesse bairro e a gente já havia pensado em fundar um projeto social que ainda não existia, que é a ONG. Isso foi em 2002, que ele entrou em contato com essa realidade; em 2003, nós fizemos já na Suíça uma associação para apoiar e buscar recursos financeiros para estar apoiando aqui. No Brasil, a fundação foi fundada em 2005, eu e o A., mais algumas pessoas. Então, nós somos os fundadores e eu sou a presidente, atualmente, da Associação. Ela cresceu muito, né. A gente começou com um pequeno número de jovens e, hoje, a gente atende 450 crianças e adolescentes; também fazemos trabalhos com os idosos, trabalhos com a família, com a música, com a educação infantil, enfim.. Um percurso que foi crescendo bastante. Nos mudamos para o Brasil em 2010. Eu faço toda a parte administrativa e financeira da Associação, escrevo os projetos, faço captação de recursos. Enfim, tenho uma atuação $360^{\circ}$, faço de tudo.

Pesquisadora - E também está envolvida com as artes plásticas, né?

C - Também, também.

Pesquisadora - Enquanto você contava que era advogada, eu pensei: mas achei que ela fosse artista plástica.

C - Não, não. Isso é só um passatempo.

Pesquisadora - Um belo passatempo! E você trabalha também com as crianças?

C - Trabalho, trabalho. Só aos sábados. De sábado, e quando dá, durante a semana, mas é mais difícil. Aos sábados e, às vezes, aos domingos, eu faço atividades de artes com eles. O A fica na música e eu estou na Arte.

Pesquisadora - Achei mesmo que você era da Artes Plásticas.

C - Não, não. Eu sou toda administrativa, do financeiro. (Risos). Tudo, assim, toda parte burocrática, estratégica, de certificações, tudo isso sou eu que faço.

Pesquisadora - Quando me mostraram os quadros, até disse: ah, estou entendendo da onde que vem essa articulação com a cultura..

C - É, mas tudo o que é de arte, a gente gosta! E entende também ser importante para todos, das formas todas aí de arte.

Pesquisadora - Uhum. Aproveitando, então, o gancho. Para você, enquanto A., em seu universo mais individual, mas também que tenha a ver com o seu papel aqui na instituição, como você compreender o que seria arte?

C - A arte? Pra mim, assim, pessoalmente, é uma alimentação pra alma, em todas as suas linguagens. Aqui, a gente tem artes plásticas e música, né, porém, a literatura, várias formas de cultura. Dança, também. Tudo, eu acho que, realmente, é um alimento pra alma, para se poder expressar uma coisa mais profunda, mais interior do ser humano, e acho que só mesmo através da arte que se consegue esta manifestação. Então, tanto pra mim, como na comunicação com as 
crianças e os jovens, é, estimular essa forma de expressão neles.. Eu acho que é extremamente importante, e em qualquer contexto, mas, principalmente, neste contexto onde a gente atua, porque as crianças vêm de situações, de famílias, às vezes, assim, muito maltratadas, com uma bagagem muito pesada. Então, entendo que a cor, a sonoridade, tudo isso, acho que vai como que limpando todos esses traumas, todos esses pesos, né, que estão em vidas tão jovens. Acho que, realmente, vejo a arte como transformadora do ser humano, do seu interior.

Pesquisadora - E como presidente da instituição e da escola? Como a instituição, em sua formulação pedagógica, conceitua e, em meio disso, faz a arte se expressar, aqui, nas atividades, nas aulas?

C - Já nasce, no nosso estatuto, a proposta, assim, bem ampla do que envolve: a assistência social, a educação, o esporte, a arte e a cultura, né. Então, acho que, assim, no final, são vários pontos que são todos importantes. E, assim, o que a gente percebe aqui no Brasil é que, muitas vezes, não se dá o valor devido a arte em suas linguagens. O esporte, talvez, seja mais próximo das pessoas e a arte, talvez, mais distante. Até porque é difícil de você conseguir recursos, enfim. Que num primeiro momento de crise, a primeira coisa que acontece é cortar os recursos voltados para a arte e para a cultura. Então, já nasce institucionalmente, a gente já nasce com essa visão de que é parte da nossa missão essa formação, não digo a do artista, porque, né, somos e não somos todos artistas. Mas, permitir esse contato e, depois, essa descoberta, porque se nós não tivéssemos feito esses quadros, por exemplo, com o grupo de jovens, esse grupo de jovens, talvez, jamais teria esse tipo de conhecimento, porque ele não poderia comprar as telas, as tintas e não teria sabido que ele tinha esse potencial nele, né. A mesma coisa com a música. Se os meninos não tem o saxofone ou a flauta; a gente tem aqui uma menina que é muito talentosa com a flauta, e se não tivesse a flauta, talvez, ela nunca teria sabido desse potencial, nunca teria se encontrado. Então, acho que a gente vai trazendo essas possibilidades e a gente vai percebendo quanto talento a gente tem aqui dentro, né. E, é só através de botar mesmo a mão na massa, seja lá qual for a massa, que esse talento, ele emerge. Senão, talvez, ele vai ficar ali latente a vida inteira num jovem.

Pesquisadora - E como se deu essa ideia de abrir um espaço para promover esse encontro aqui na escola de música?

C - A escola de música foi muito natural, porque, desde o início, sempre teve música, e a partir da oportunidade mesmo de ter este espaço, que eu havia, na época, escrito um projeto que foi aprovado pelo Fundo da criança e do adolescente. Então, pensando no que a gente gostaria de que acontecesse: se era só cultivar o projeto de música dentro do CCA, que é o Centro de Crianças e Adolescente, ou se alguma coisa a mais. E, ai, todos que estavam envolvidos no projeto alí naquele momento, todo mundo animado: vamos fazer uma escola. E, aí, foi: fizemos a escola. E. aí, nossa, vai muito bem.

Pesquisadora - Então, a minha pesquisa, ela também se volta mais à essa questão da educação musical. Então, a educação musical dentro do contexto institucional infere pensar as práticas institucionais, o projeto pedagógico e, deste modo, eu gostaria estar conhecendo também um pouquinho sobre os princípios e valores que nortearam e que norteiam as práticas educacionais aqui, a maneira como vocês se organizam nas atividades, no planejamento, nas aulas, enfim, em tudo o que envolve a escola de música.

C - Bom, assim, o dia-a-dia da escola é a A. que coordena, né, tanto o planejamento das atividades, eu não estou envolvida nesse processo, porque é da minha competência. Enquanto instituição, a gente tem ali a nossa missão, visão e valores, né, e esses permeiam todos os nossos projetos. Então, assim, nós entendemos a promoção de uma cultura de paz, é isso que a gente 
entende que a arte que ela também está promovendo, né, tanto através das artes plásticas, como da música, como de todas as outras atividades que a gente faz. Que a gente busca, que a gente está numa comunidade violenta, né, com diferentes números de problemas ligados à droga, à álcool, a violência contra a mulher também. Então, assim, entre esses nossos valores institucionais, tem a paz, a verdade. A verdade, a gente acha que é, no nosso relacionamento com todos, né, com as crianças, com os jovens, com os funcionários, é sempre essa verdade, essa transparência. É uma troca, assim, muito construtiva e que a gente está vislumbrando, e quem são, né, essas pessoas que estão colocando isso em prática. A gente tem essa troca bem verdadeira e é uma busca, na verdade, acho que de cada um, né. E que, na verdade, se reflete aqui, nas nossas atividades, então, acho que não é só institucional, mas é pessoal também, né, de como a gente está vivendo, como a gente está trazendo aqui pro mundo, né. E, amor, obviamente. A gente está cercado de crianças que têm, assim, muitos problemas de afetividade, ausência de figuras importantes na família, né, pai, mãe, enfim.. E, aí, assim, a gente acaba também sendo presente nesse sentido; a gente se torna a segunda família, muitas vezes, a primeira família. Então, é um espaço que acolhe, que abraça, que acompanha nos problemas. A gente está bem presente mesmo. Não digo todos pelo nome, mas muitos pelos nomes. A gente viaja com eles, a gente vai ver mostras de arte juntos, a gente passeia juntos. Só não vou se tem assim um... São prioridades estar com eles.

Pesquisadora - Uhum. Sim, sim.

C - Então, acho que é por aí.

Pesquisadora - Assim, eu tenho o roteiro pelo qual vou me baseando, mas vou seguindo conforme a conversa vai se abrindo.. Vocês já trouxe alguns elementos, mais pensando no seu papel, da forma como você contribui aqui na escola de música.. dentro dos vários motivadores que você já trouxe, o que vocês visam promover com a escola de música?

C - A gente cria oportunidades, né. A música na infância, a gente sabe que é fundamental para a formação do ser humano, para a capacidade de interpretação das situações, da formação até da inteligência e das percepções de raciocínio, enfim. Essa, então, na infância. Então, assim, a gente tem a proposta de musicalização infantil aqui, - tem na creche também, que a gente faz, eles não vêm até aqui, a professora vai lá, né. Então, isso é na primeira infância, daí, a partir do momento que eles são jovens e estão já com uma idade, com uma maturidade para entender se é o que querem para a vida deles, então, pode se tornar uma profissão ou um momento bonito e importante que tiveram na vida, que curtiram, que agregou, que foi em grupo, que tiveram a oportunidade, que tiveram a experiência e que foi bem feliz na vida deles, né. Então, a gente quer deixar momentos felizes e criar oportunidades profissionais também.

Pesquisadora - Uhum.

C - Então, acho que é esse o sentido. Que, no final das contas, a gente fica pensando em possuir tantas coisas estruturadas, mas acho que pequenos momentos de felicidade tornam as pessoas felizes, né. Acho que, primeiro, para mim, são coisas que proporcionam momentos felizes e oportunidade. Quem se descobre, aqui, seu talento, provavelmente, vai seguir uma carreira profissional, mas não necessariamente, não é o que move a gente.

Pesquisadora - Uhum. É, uma sensação que tive aqui, principalmente, conversando com a A., é ver que é uma escola de música, mas também muito além disso, né. Como você já trouxe: essa coisa do afeto, do acolhimento, essa coisa mais doméstica mesmo. Isso fica muito claro quando vejo, quando já vim aqui, as crianças aqui, como realmente fosse uma casa. Essa ambientação, aqui, é uma expressão de algo que está para além mesmo da escola. Isso foi bem interessante de observar na instituição. E você trazendo isso na fala, a A. trouxe também. E é bem enriquecedor 
para a gente estar compreendendo os espaços e os atores que estão contribuindo com isso. É bem legal.

C - É! E o fato de os nossos projetos estarem todos em casas. Aqui embaixo também é casa. Acho que é bem nesse sentido mesmo: é a casa! A gente está, aqui, acolhendo uma grande família. A gente se sente bem para que eles também se sintam bem.

Pesquisadora - Agora, pensando a estrutura do projeto pedagógico, mas que não é a sua área, eu vou fazer as perguntas e, enfim, sinta-se à vontade de responder ou não. Aqui na instituição, no projeto, quais são as principais referências e inspirações utilizadas por vocês para estarem fundamentando o trabalho? A organização do projeto pedagógico, o ensino, as práticas de ensino e aprendizagem..

C - É, isso é com a A. mesmo.

Pesquisadora - Ok. Tudo bem. Sobre as atividades realizadas pela equipe, você poderia me descrever?

C - Assim, eu sei que têm as aulas de música, as oficinas, práticas em conjunto, aula teórica, têm as apresentações em alguns determinados momentos, mas não sei te falar nada de mais, assim.

Pesquisadora - Uhum. Entendi. Pensando um pouco sobre a relação entre a educação musical e a formação cultural infantil, qual é a sua perspectiva sobre a importância da educação musical, sua influência, para esse processo inicial da formação das crianças e dos jovens? E também pensando neste contexto e no contexto destas crianças.

C - Ah, assim, o tipo de música consumida aqui, nessa comunidade e em tantas periferias, é o funk, o forró ou outras formas de música mais simples, mas, é, ainda que sim, está bom ou não está bom, é o vulgar. Quem nunca viveu, o que acontece na periferia, né, esses funks.. Então, acaba sendo muito limitado esse universo que é apresentado à criança e ao jovem, né. É o acesso que eles têm. Então, eles acabam nem tendo a possibilidade, a oportunidade, de conhecer outras propostas. Aí, vindo aqui para o espaço, dos nossos professores, eles são extremamente bem formados, com conhecimento muito rico, e trás para a comunidade, que não teria uma outra forma de acesso, porque é o contexto em que eles vivem, essa riqueza da música popular, além os aspectos de músicas de outras culturas, o erudito, enfim.. abre, é, a criança, o jovem, para um universo que é muito distante do cotidiano, da vida, dessas crianças. Então, é muito difícil assim essa estatística ou esse conhecimento de quão profundo é o impacto transformador disto, né. Da mesma forma, às vezes, a gente, nos projetos sociais, tem sempre aquela pergunta: ah, fala aí os resultados qualitativos. Quantitativo é fácil, a gente faz as contas, é fácil. Qualitativo, né, qual é o impacto que estou tendo na vida de uma criança que passa aqui com a gente, de oito a nove anos, nesta fase ou talvez até mais... Qual é o impacto qualitativo que a gente está tendo na vida dessas crianças? Eu sinto qual é. Eu só acho que é muito difícil traduzir isso no papel, em palavras, porque talvez ele não vai se manifestar ainda quando a criança é jovem, mas ele é totalmente transformador, do destino até de uma criança que de repente ela iria pro tráfico, para as drogas, e vai estar sendo um professor de música. Como o são os nossos professores, o W. mesmo, amigos dele, jovens que morreram com drogas e em situações bem complicadas. Então, o que eu vejo que a música, e não só a música, é esse afeto, esse acompanhar a criança nas suas necessidades, nas suas exigências. É, onde uma família, que por tantas motivações, está ausente, eu vejo que é bem transformador. Realmente, você dá, você apresente a ele uma oportunidade, uma situação que não ele não teria isso. Então, enfim.. não só a música, né, não só a arte, mas acho que o que mais entra em todo esse processo é o afeto, a atenção pelo ser humano, a sincera preocupação por aquilo que aquele jovem, aquele menino, está sofrendo naquele momento, está presente, podendo ajudá-lo onde dá para ajudar. Então, acho que é isso a base de tudo, depois, as outras situações, 
elas vão se complementando. Elas vão fortalecendo, mas o amor, o afeto, nas ações, elas seriam vazias.

Pesquisadora - E pensando no seu percurso aqui na escola de música, há alguma cena que te remete isso? Ao ter acompanhado uma criança ou um grupo de jovens, e de você presenciar a repercussão desse encontro com a estética musical?

C - Claro. O mais fácil de tudo são os meninos que estão na banda, porque são meninos que estão desde o começo com a gente, desde lá debaixo (ONG), e hoje são meninos grandes. O O. está com dezessete anos, a X. acho que está com quinze, então, Z., enfim.. São meninos que cresceram com a gente e, hoje, eles estão mocinhos. E aí, sim, é evidente, muito claro, que pra eles foi um divisor de águas, que depois da música, é bem claro que, potencialmente, muitos deles poderão seguir mesmo a carreira musical, porque já fazem parte de um grupo, entre aspas, de "elite", digamos assim. Que é o grupo musical mais bem formado, que mais se dedica também e que a gente tem aqui na casa. E, é evidente a transformação na autoestima, na disciplina, nos interesses, na postura, no comportamento. Então, assim, é muito evidente. Sem dúvidas! E eles também têm perfeitamente a consciência disso. Quando a gente conversa com eles, eles colocam nas palavras e a gente vê as avaliações.

Pesquisadora - Bacana! Para estar finalizando a nossa conversa, e também porque, na minha pesquisa, eu não vou estar em contato direto com as crianças; de alguma forma, vou encontrá-las por meio das vozes dos educadores e dos coordenadores da escola. É, queria saber, por meio do seu olhar, quem são os alunos e alunas que ocupam, que convivem nesses espaços da escola? Seja sobre eles aqui na escola, sobre a sua realidade; daquilo que você percebe de potências e de dificuldades.

C - Então, a maior parte são alunos que frequentam o CCA, são alunos que vêm de um contexto de vulnerabilidade social elevada. Alunos que a gente sabe que, geralmente, tem mãe, mas que não tem pai, que tem padrasto; a gente sabe que têm situações de violência doméstica de diversos tipos e níveis. Então, são alunos que vêm de um contexto social bem complexo. Que ligados à Associação, eles já têm um acompanhamento e nós abrimos também espaço para alunos da comunidade para terem acesso, então, é aberto. Na escola de música, é feito uma seleção, há um processo seletivo, porque o foco é que quem entra nessa escola, pra também a gente utilizar o máximo, né, do investimento que a gente faz aqui. E que tenha interesse e demonstre. Há o teste de admissão. E, aí, tem os meninos da comunidade, que eu vejo que às vezes têm uma situação um pouquinho melhor que aqueles que estão na $\mathrm{ONG}$, e, enfim, mas são jovens, todos eles em situação de vulnerabilidade. A partir de uma certa idade, eles tem que tomar a decisão de querer fazer música. Na musicalização infantil, todos os grupos, os pequenos e médios, ali na ONG, acabam participando porque a gente entende que eles precisam ter o contato para verem se gostam ou não gostam. Então, eles fazem essa musicalização infantil e muitos deles gostam, têm bastante afinidade com a música. A gente percebe que, talvez no começo, é difícil para o professor administrar tantos alunos, mas com o tempo, vai entrando no ritmo. Os pequenininhos são bem, são bem animados assim! (Risos) Nem sempre é fácil de conter, né. Mas, assim, o perfil é esse: jovem que precisa realmente de uma oportunidade, que não poderia pagar uma escola particular de música e, então, isso não faria parte da vida dele. Até tem jovens que frequentam a escola particular, mas que a gente sabe que a família faz um grande esforço para que ele vá para uma escola particular e jamais, com esse mesmo esforço, pagar também uma escola de música. Então, já seria uma coisa que não estaria presente na vida deles.

Pesquisadora - Uhum. 
C - Então, a gente acaba abrindo não só abrindo para quem está na escola pública, mas também para quem vem da escola particular que seja da comunidade, que tem interesse, que leva a sério. É isso que a gente enxerga como proposta de oportunidade para quem está nessa situação de exclusão.

Pesquisadora - E você, dentro do papel que você ocupa na escola, junto com os demais profissionais da equipe, enfrenta dificuldades ou desafios para implementar as ações do projeto, para que aquilo que é idealizado pela equipe seja realizado? Há desafios cotidianos, digamos assim?

C - O maior desafio é o financeiro, porque é tudo gratuito, né. Eu escrevo muitos projetos, tento entender de onde estão as oportunidades pra gente conseguir financiamento. Não é fácil! Não é fácil a área da cultura, porque quando se tem uma crise, é a primeira em que o pessoal corta, né. A gente é bem pequeno, então, a gente não tem muita visibilidade; agora que está começando a ter um pouquinho, veio a televisão.. Enfim, isso, óbvio que ajuda, porque se uma empresa vai patrocinar um projeto aqui ou de outro lugar, ela vai querer visibilidade. Infelizmente, está longe de acreditar na cultura, na causa. Então, obviamente que eles querem se promoverem e a gente encontra, assim, no Brasil, uma falta de atenção a essas realidades, a esses contextos, mas uma atenção sincera, né, não só "eu vou te dar dinheiro, porque eu preciso me promover", não! "Eu vou te dar dinheiro porque eu acredito na cultura!".

Pesquisadora - Pela causa.

C - É! "De você estar transformando uma realidade aqui no meu país e está melhorando e eu quero contribuir com essa melhora. Então, a dificuldade maior aqui é a financeira. A equipe é fantástica, eles são bem dedicados, amam o que fazem. Então, deste ponto de vista, não sinto dificuldade. Eles conseguem solucionar facilmente os desafios do dia-a-dia. Nem entro no mérito, para falar a verdade, eles dão conta totalmente. Eu diria isso.

Pesquisadora - Então, para concluir, a escola estabelece contato com outros projetos da comunidade, não sei se tem, que se envolvem também com a música ou com outras modalidades artísticas?

C - Não. A gente não tem nenhuma parceria. A comunidade é carente, extremamente carente de espaços culturais. A gente tinha um bom relacionamento com o CEU Alvarenga, mas com a mudança de gestão, com o novo prefeito... que já era sucateado, sucateou de vez. Colocou uma equipe que não tem nada a ver com a cultura, colocaram uma gestora de creche, que não tem nenhum interesse e amor pela cultura. A gente não consegue nem espaço para apresentar. Antes, já era meio sucateado, mas a gente alugava ali, servia para uma apresentação musical na comunidade, que era sempre lotada, e fazia. Hoje em dia, os espaços fecham às seis horas da tarde, porque o pessoal não pode fazer hora extra ou então não está disponível e, então, é uma má vontade incrível, né. Outros espaços culturais não têm. Então, a gente se encontra em uma situação extremamente precária. De ausência de tudo. Aqui, a cultura não chega. Não há espaço. Mesmo se a gente quisesse, por exemplo, a gente tem professores aqui que também ensinam em outras ONGs da comunidade, até seria bacana de fazer um festival, alguma coisa, mas a gente não tem espaço. Então, nem se a gente quisesse, a gente não teria condições para estar fazendo nada, porque a gente está aqui, num amontoado de tijolos e cimento e não tem um espaço cultural.

Pesquisadora - É um desafio, né?

C - É!

Pesquisadora - Um grande desafio, acho.

C - Certamente! 
Pesquisadora - Bem, A., acho que era isso. Te agradeço mais uma vez por estar recebendo e colaborando para com o desenvolvimento da minha pesquisa. Obrigada!

\section{ENTREVISTA 4}

Realizada em 24 de Outubro de 2018.

\section{D - Assistente de coordenação.}

Pesquisadora - Primeiramente, gostaria que você se apresentasse, que falasse um pouco sobre você. Qual é o seu papel aqui na escola de música, qual é a sua função.

D - Bom, aqui na escola, eu sou assistente de coordenação. Eu dou suporte para os professores, faço o atendimento dos alunos, o atendimento aos professores e o atendimento ao público em geral. Eu faço mais o trabalho administrativo, apesar da minha formação em pedagogia. Eu não faço tanto esta parte pedagógica aqui dentro da escola. No dia a dia, eu tenho muito contato com os alunos e, então, eu acabo passando muita informação importante para os professores com relação às dificuldades dos alunos. De certa forma, a minha opinião influencia muito, é, o movimento dos alunos aqui dentro. Mas o meu trabalho acaba sendo mesmo o administrativo.

Pesquisadora - Ok. Queria, desta forma, pedir a sua ajuda, a sua contribuição para pensar um pouco a relação entre educação musical e formação cultural, tema da minha pesquisa. Queria, assim, pedir ajuda para pensar esse caminho de investigação no contexto de projetos sociais, dentro da escola de música. Então, a primeira pergunta que faço a você, e também conhecendo um pouco sobre o seu papel aqui, é: para você, como você compreende o que seria arte? A partir da sua opinião pessoal e profissional, da sua vida, como você definiria arte?

D - Arte, pra mim, é tudo! Seja a música, seja a dança, seja o teatro. Tudo o que você considere arte, no seu ponto de vista, depende do que você acredita, depende muito do seu ponto de vista. Se você falar para mim que um pontinho preto no chão é arte, eu vou acreditar naquilo que você tá me falando. Então, depende da criação, da construção, talvez, familiar, do seu convívio.. Porque os pontos de vistas mudam. Então, depende..

Pesquisadora - Uhum. E para você, qual é a sua relação com a arte? Como ela atua em sua vida? D - A arte é tudo. A arte é a música, é a dança, é o teatro, é a natureza.

Pesquisadora - E você percebe alguma relação da arte com o caráter de ser popular ou erudita, ou no caso da música, de ser uma música de novela, de estúdio ou ser proveniente de uma ópera.. se há nisso alguma influência para definir o que é ou não arte?

D - Não. Para mim, Arte é arte.

Pesquisadora - Ok. Pensando, agora, sobre a proposta desta escola de música, como que você delineia essa compreensão da arte? No caso, a música como arte. Para estar, assim, pensando, a partir disso, o ensino da música..

[SILÊNCIO]

Pesquisadora - Pensando, talvez, a equipe como um todo. Se você percebe uma concepção da arte em específico.

D - Na verdade, eu acho que a escola, como um dos seus objetivos, tem como uma das funções que é a música e com ela, em si, promover transformações de caráter, não só a técnica da música, entendeu. Que eles tenham domínio técnico do instrumento, que eles aprendam técnicas vocais, 
mas que a música, de certa forma, influencie dentro da casa deles, na família, no convívio social deles..

Pesquisadora - E você acredita nisso também?

D- Acredito. Eu vejo isso acontecer. Isso é muito visível. A gente tem retorno da família, retorno dos próprios alunos. Eles contam que mudou o aluno quando começou a fazer a música, que está mais disciplinado, que está mais comunicativo, que conseguiu fazer amizades, que conseguiu a conversar melhor..

Pesquisadora - Tendo uma função bastante importante aqui dentro, gostaria de saber um pouco mais sobre como você percebe o desenvolvimento da música e como que impacta as crianças e adolescentes que estão aqui no projeto. Pensar neles quando entraram na escola e o desenvolvimento deles a partir de então. E, acho que como você acompanha isso e pudesse relatar um pouco...

D - No começo, as crianças chegam, aqui, muito tímidas, retraídas. E, aí, é um processo, né: elas se adaptam, primeiro, com o espaço, com o lugar, com as pessoas e, aí, elas vão vendo que isso aqui é delas, e que elas também podem ter acesso à música, que não são apenas para as pessoas de alto nível social, que elas podem fazer isso, que isso daqui é delas, e que têm pessoas aqui por elas. E, conforme elas percebem que têm pessoas aqui por elas, elas também se entregam. E isso é muito bonito. E, a partir daí, elas começam a... não sei definir, é.. [SILÊNCIO] É uma diferença muito grande de quando eles chegam e de quando eles saem daqui. Têm pessoas que não conseguem terminar o programa daqui da escola, né, porque tem vezes que acontece alguma coisa no caminho. Mas o impacto que acontece no período de tempo que eles ficam aqui - se foi um ano, se foi dois anos, se foi seis meses - é muito grande. E, todos eles querem voltar aqui para agradecer, para falar o quanto que é importante, o quanto isso daqui significou para eles.

Pesquisadora - Você tem algum exemplo concreto, uma história de alguém, de um aluno ou aluna, que te marcou?

D - [SILÊNCIO] Ah, é que eu sou suspeita! (Risos) Eu sou suspeita para falar dos alunos. Mas tem um aluno que era muito retraído, que por diversas circunstâncias da vida, problemas na família e diversas outras coisas.. ele tinha medo de falar com as pessoas e, a partir do momento que ele entrou aqui, ele começou a desenvolver a fala, começou a perder o medo de se aproximar das pessoas e, hoje, ele é super extrovertido. Acho que foi uma das histórias marcantes pra mim. Uma das histórias bonitas.

Pesquisadora - É, e pensando, agora, a estrutura da escola de música, a parte político-pedagógica, quais são os principais valores e princípios que a escola de música carrega em si, na construção tanto das práticas, como da organização em geral mesmo do projeto?

D - Os principais? Nossa! Então, a gente ainda não tem os princípios, missões e os valores em si. Da escola de música, a gente ainda tá nesse processo, a gente ainda tá se moldando, a gente ainda não construiu, especificamente, esta questão de valores. Mas, de todo modo, é formar jovens, adultos, crianças, para que sejam ativos na sociedade, que saibam defender seus pontos de vistas, que não tenham medo de se expressar.

Pesquisadora - Uhum.

D- Acho que é isso.

Pesquisadora - Ok. Quanto às práticas da instituição, do projeto da escola de música, vocês, enquanto equipe, apresentam algumas referências que inspiraram o desenvolvimento das atividades propostas? 
D - Tem. A escola usa o modelo T.E.C.L.A, do Swanwick. E é um dos modelos dentro da música e é esse o modelo T.E.C.L.A tem cinco diretrizes para se trabalhar que, aí, a A. (coordenadora pedagógica) sabe explicar melhor.

Pesquisadora - Ok. Sendo a escola recente, você participou do processo de sua criação, da organização?

D - Eu vim trabalhar aqui depois de fundada, quando já estava funcionando. Com esse formato, eu participei sim, dessas primeiras conversas.. (inaudível). Mas, antes, de se pensar em criar a escola, não. Entrei depois.

Pesquisadora - Uhum.

D - Eu trabalhei primeiro foi na instituição (associação socioassistencial), que eu fui uma das atendidas da Casa quando pequena.

Pesquisadora - E quando você veio trabalhar aqui, do que você participou?

D - É, foi a forma de trabalhar mesmo: definir o que a gente espera e como conseguir com o nosso trabalho. Mas foram, ainda, poucas reuniões. A gente ainda.. não foi o suficiente. E nas demais horas, a gente trabalha muito e, às vezes, não sobra tanto tempo para falar sobre outras coisas..

Pesquisadora - Uhum. E daquilo que vocês já conversaram, assim, o que vocês já discutiram quanto ao que esperar do que alcançar por meio do trabalho de vocês?

D - Nós esperamos que, alguns alunos, é, sigam a carreira de música como profissão; que alguns alunos, que através desta formação, consigam, de alguma forma, trabalhar como multiplicador de música em ONGs, assim como aqui. Acho que é os principais..

Pesquisadora - Sobre as atividades que vocês oferecem aqui, se puder me descrever um pouquinho...

D - Todo aluno que entra aqui, é, precisa fazer um programa de atividades semanais, e, aí, dentro deste programa, ele vai escolher um instrumento principal, um instrumento complementar e duas aulas teóricas. E, aí, dentro das opções, de aula teórica tem instrumentos de sopro, trombone, saxofone, clarinete, trompete, tuba, tem harmonia, tem teclado, violão, contrabaixo, guitarra, tem percussão e bateria, tem o canto e o coral. O coral, a princípio, eram todos os alunos, mas, daí, a gente não estava tendo muita demanda, muito resultado e, aí, ficou aberto para os interessados e para os alunos de canto. Então, daí, tem o coral, o coral infantil e a gente tem também o coral da terceira idade. Então, os alunos vêm aqui pelo menos duas vezes na semana para fazer o instrumento principal, aí, o instrumento complementar, indicado pela escola, e, aí, eles têm o violão. E o instrumento complementar, a idéia e montar turmas grandes.

Pesquisadora - Mais para frente?

D - Não, isso já acontece.

Pesquisadora - Entendi.

D - Então, é turma que a gente encaixa até dez alunos. Nas aulas dos instrumentos principais, não, são menos alunos.

Pesquisadora - Tá.

D - E, aí, tem o violão, como complementar, percussão e canto. São essas turmas que conseguimos encaixar mais, em uma maior quantidade de alunos. E as turmas teóricas: uma teoria musical e uma teoria rítmica. Isso no primeiro semestre. No segundo semestre, a teoria rítmica vira prática de conjunto. que é onde os alunos começam a tocar em grupo. Daí, a gente monta uma pequena banda. Eles são vários grupinhos de pequenas bandas.

Pesquisadora - Uhum. E, dentre essas atividades, quais você percebe que os alunos gostam mais? Que demonstram maior animação? 
D - Eles gostam muito da prática de conjunto. (Risos). Eles gostam muito de tocar.

Pesquisadora - Desde o processo de criação da escola até o momento quanto você pode participar das atividades que se propõem, da realização das atividades, enfim, do funcionamento em geral da escola..é, ao seu ver, quais são as dificuldades que vocês enfrentam e quais as limitações que você identifica?

D - As dificuldades tem mais a ver com a frequência dos alunos. A gente tem um pouquinho de ausência dos alunos, e a gente tenta resolver, mas é uma coisa que a gente ainda não conseguiu. $\mathrm{E}$ a questão de credibilidade também, porque, às vezes, as pessoas não acreditam muito no nosso trabalho em si por conta de ser uma escola de música na periferia. E as pessoas não acreditam que um projeto assim pode acontecer.

Pesquisadora - Quanto a essa primeira dificuldade que você relatou, a questão da frequência dos alunos, você identifica algumas causas de alguns alunos não conseguirem vir a escola com certa frequência, como até exige a escola, né, já que tem um programa de três anos, com uma certa regularidade ao longo da semana, com aulas, enfim...

D - Desde o começo do curso até agora, melhorou bastante, mas muitas vezes são outros compromissos que colocam em primeiro plano.

Pesquisadora - Tipo o quê?

D - Tipo um trabalho de escola, ou, então, marcou outro compromisso no horário da escola; a mãe que levou para sair em outro lugar, aí, não tem como ir, porque é a mãe que é a voz ativa; ou, então, que passou mal, qualquer coisinha.. Motivos pequenos. E isso que era a nossa preocupação maior, esses motivos pequenos.

Pesquisadora - E quanto à essa outra dificuldade que você trouxe quanto a não acreditarem em ser possível uma escola de música aqui na periferia, quem são essas pessoas?

D - A própria comunidade. Durante o nosso período de divulgação, a gente ia panfletar e muitas pessoas não deixavam a gente cola panfleto, porque achavam que era mentira, que a gente ia enganar as pessoas, que não existe aula que é de graça.. A gente ouviu muita coisa.

Pesquisadora - Ah, é? E como vocês lideram com isso?

D - A gente não colava os panfletos. Assim, não tinha muito o que fazer. No panfleto, a gente colocou o logo da Associação, que tem mais peso, porque é mais conhecida. Mas com as pessoas que não acreditaram, a gente deixou acontecer; e, agora, as pessoas estão vendo que realmente é verdade.

Pesquisadora - A escola de música está quanto tempo em funcionamento?

D - Ah, está beirando os três anos.

Pesquisadora - E, nesse tempo, você percebeu se houve uma ressignificação, digamos assim, da opinião da comunidade?

D - Já.

Pesquisadora - Tá. Agora, tenho uma das últimas perguntas para te fazer. No seu papel aqui, enfim, acompanhando o projeto, você perceber alguma relação e a importância da educação musical para a formação cultural dos alunos?

D - Eu acho que a educação, por si só, não cumpre com esse papel de formar culturalmente. E, eu acho que os nossos jovens, hoje, não estão muito interessados na cultura, ainda mais na cultura brasileira. Eles escutam muita música, fazem, até, coisas culturais, mas eles não sabem que estão meio que se formando culturalmente. Então, quando tem um projeto que trabalha com formação musical, que ensina música, que ensina a tocar um instrumento e não só isso, porque, aqui, a gente, além de ensinar a tocar um instrumentos, de todas as aulas, busca a levar eles a passeios 
culturais, a eventos, a tudo o que tem de novo, a gente sempre procura levar eles para assistir. Então, é muito importante e influencia muito na vida deles e na sua formação.

Pesquisadora - Eu fiquei pensando, agora, a coisa de quando vocês foram panfletar, anunciando a abertura da escola de música e que muitas pessoas acharam que era mentira.. eu fico pensando que como deve ser para eles essa relação, também de ir para outros espaços culturais.. Tanto pela sua fala, como também o que a gente vê, né, que o Estado não comparece nessa área da cultura entre outras, principalmente, nas periferias. Como que é para essas crianças terem espaços para uma educação musical e terem passeios culturais nesse processo? Como você percebe esse movimento para elas?

D - Acho que é uma experiência única. Eles se sentem vistos, importantes. Eles têm mais vontade de estarem aqui, de aprenderem, de estudarem e de ver as coisas. Não só porque eles estão aqui, mas porque eles sabem que as coisas existem e que eles podem ver e fazer. E a gente tem até alguns relatos deles contando como que é essas experiências deles ao fazerem esses passeios. Eles relatam o que eles sentiram vendo um espetáculo, vendo um musical ou um show. Eles contam em forma de poema ou redação e, aí, a gente coloca no mural. É uma forma de saber o que eles estão achando.

Pesquisadora - E se você puder falar um pouco mais sobre quem são essas crianças que participam do projeto. Quem são elas? Qual é a identidade dessas crianças?

D - Bom, as nossas crianças são crianças da classe baixa, que moram com pais separados, geralmente, a maioria delas, que não tem muito acesso à cultura, nem a lazer, que estudam em escola pública, que vivem em uma casa que não tem uma estrutura familiar legal, é, que em casa, tem muitas brigas, que a família não se entende, que o pai, por ter que trabalhar para pagar as contas, não tem muito tempo para passear com o filho e que não dá muita atenção para essa criança. Então, é uma criança carente de afeto.

Pesquisadora - E em relação à comunidade onde elas vivem?

D - Bom, o distrito, aqui, no mapa de vulnerabilidade social é um lugar considerado de média alta vulnerabilidade social, é um lugar bem perigoso, não tem parque, não tem nenhum lugar cultural.. O único lugar que tem próximo, e nem é tanto, é o CEU Alvarenga que é da rede CEU, ms que fica longe para eles irem ver alguma coisa. Mas é um bairro muito perigoso, não dá para ficar na rua..

Pesquisadora - E há alguma articulação que vocês conheçam aqui na comunidade com trabalhos e projetos sociais, e se há trabalhos assim na área, que trabalhem com arte e cultura?

D - Tem um projeto de música, que não é exatamente um projeto, é um grupo de música e de dança que é o Batuque arte e que acontece em um espaço de um CCA também. Que, aí, é um grupo de dança, canto, percussão, bem legal. E, aí, eles realizam shows. Eu não sei como eles estão agora, mas projetos, assim, específicos para a cultura e para arte, não.

Pesquisadora - E as crianças trazem alguma coisa, assim, quanto ao que vem lá de fora? Culturalmente, falando.. As referências do próprio bairro, da região ou coisa assim?

D - Do próprio bairro, não. O único lugar, assim, é o CEU Alvarenga.

Pesquisadora - Entendi. Ok. E, agora, pensando na formação cultural: você vê se, para elas, assim, a música pode ter vários papéis, funções.. como você mesmo trouxe essa questão da carreira, da profissão. Se há também outras esferas da música para a formação delas? Como a música vai se configurando na vida delas?

D - Eu acho que, a partir do momento em que elas começam a vivenciar a música na prática, as que não vão seguir carreira, elas terão, sim, outro olhar para a música. Seja tocar com a família. Têm alunos que fazem música para tocar na igreja, têm muitos que querem formar grupinho de 
banda para tocar com os amigos. Então, acho que sim. Muitos deles querem a música para outras vertentes também.

Pesquisadora - E no sentido de importância pessoal, você percebe se há? Isso é expresso de alguma forma?

D - Acho que pela postura mesmo. A música fala por meio.. E eles são muito expressivos, a postura muda.

Pesquisadora - Para finalizar, sabendo que você participou do projeto social quando criança, queria saber um pouco sobre a sua experiência. Como que foi para você?

D - Bom, eu sempre fui muito tímida. (Risos). Eu sou muito tímida. E entrar na ONG foi, para mim, muito importante. É, eu cresci muito. Antigamente, eu nem abria a boca para falar e, hoje, até falo em público. (Risos). E a ONG me deu muitas oportunidades, né, tanto que, hoje, eu trabalho aqui. É, e a ONG não foi um lugar onde eu cheguei e copiava coisas, que estava lá só para ocupar espaço. Eu estive em um lugar onde tinha pessoas capacitadas e me deram materiais para explorar, para que eu pudesse explorar, para que eu pudesse criar, para que eu pudesse me desenvolver. Então, eu aprendi muito. Eu tive muitas oportunidades. Tudo o que me aparecia pra fazer, se era pra cantar, se era pra dançar, se era pra pintar, se é pra fazer aula de informática, eu fazia.. Então, eu aproveitei de tudo e acho que foi uma oportunidade única. Eu me desenvolvi muito.

Pesquisadora - E você entrou lá com quantos anos de idade?

D - Com dez anos.

Pesquisadora - E você lembra? Tem memórias da sensação de como era estar lá?

D - Sim. Várias! Na época, a ONG chegou a fazer uma parceria com o Batuque Arte e, então, naquela época também tinha música e, então, eu me lembro dos shows que eu fazia com o Batuque Arte.. Eu cantava, dançava. Me lembro dos passeios que eu nunca tinha passeado, que eu nunca tinha ido à praia. Então, todos os passeios que eu fiz, eu fiz por causa da ONG. E, então, são coisas que a gente não esquece, né.

Pesquisadora - Ah, legal. Bem, te agradeço pelo tempo e pela entrevista, por me ajudar com o desenvolvimento da minha pesquisa.

D - Magina.

\section{ENTREVISTA 5}

Realizada em 25 de Outubro de 2018.

\section{E - Regente do coral infantil, juvenil e da terceira idade, professor de teoria musical, de musicalização infantil, de contrabaixo, violão e canto.}

Pesquisadora - Primeiramente, gostaria que você falasse um pouquinho sobre você, sobre seu papel aqui na escola, sobre a sua formação..

E - Uhum. Sou músico desde garoto. Comecei com o violão, depois de um bom tempo, fui estudar canto, depois, regência em coral e, a partir daí, os estudos foram se aprofundando. Em 2004, participei do meu primeiro projeto em escola pública, era um programa de fanfarras, fiz um concurso para instrutor de bandas e fanfarras e, depois, acabei entrando em um projeto de canto e coral, que era um que tinha em São Bernardo do Campo, coral infantil dentro das escolas. A partir daí, fui para a Universidade, fiz UNESP, me formei em Licenciatura e formação musical. O 
curso tem, basicamente, as mesmas disciplinas que um curso de Composição e Regência, algumas com extensão um pouco mais curta, e não tem a parte de composição, que é especificidade do curso de CR. Somado-se a isso, tem a carga de estágios de educadores musicais e a parte de.. as disciplinas educacionais, mais a carga de estágio. A partir daí, eu trabalhei num projeto de formação de professores, mas formação dentro de escola. A gente atuava junto com o professor, junto com os alunos, 7 anos em Mogi das Cruzes. Era um projeto chamado Tocando $e$ Cantando. Era um projeto que a gente fazia com as crianças, e que foi uma parceria da Universidade com a prefeitura de lá. Isso durou 7 anos. Mas, ampliando, eu sou regente de coro há vinte anos. Coro infantil, adulto e terceira idade. Isso se ampliou também com as aulas na Universidade. E, atualmente, também atuo como regente de orquestra em igreja. Como instrumentista, sou violinista, meu principal instrumento é o contrabaixo elétrico, toco violino também, à noite em eventos, piano, também. E, aqui dentro, eu sou regente dos coros, tanto do coro infantil, como do coro juvenil e o coral da terceira idade também; sou professor de teoria, tento entrar com a estruturação musical melódica; professor de musicalização infantil, de contrabaixo, violão e canto. São as minhas atuações aqui dentro da escola.

Pesquisadora - Você tem uma atuação extensa aqui na escola, ao que parece.

E - Um pouquinho. (Risos). Tenho algumas turmas de aula de canto; regência nos três coros e alunos de contrabaixo e, também, de violão; teoria e musicalização. Um carga horária um pouquinho puxada. E, atualmente, estou atuando e preparando o próximo da banda, mas como uma questão temporária até que se tenha um aluno que assuma a função de baixista na banda da escola. Então, nesse ano, também, entrei atuando como contrabaixista na banda, mas, aí, claro, não é uma função permanente, é pra suprir uma necessidade até que se tenha alunos prontos pra assumir essa função. Essa é a minha atuação aqui dentro.

Pesquisadora - Bem, dentro do escopo da minha pesquisa, eu irei fazer algumas perguntas mais genérica e até outras para poder se pensar o projeto. Primeiro, eu queria conhecer, a partir da sua perspectiva, a sua compreensão ou como você define o que é arte.

E - É difícil definir arte, né?! Eu diria que arte é uma palavra de quatro letras, né, até porque.. (Risos).. música é uma palavra de seis e arte, uma palavra de quatro. Porque é difícil demais definir em palavras um fenômeno tão grande. Mas vamos lá! A arte é uma oportunidade de você se expressar, é uma oportunidade de você se comunicar, é uma linguagem! Poderia chamar de linguagem! Que me permite trazer, me comunicar com o mundo à minha volta, com aquilo que consigo ser capaz de fazer. Uma forma também de crescimento! Até porque, também, o que acho bacana da arte é que você traz para fora um crescimento muito interessante, porque você trabalha o seu cérebro inteiro para fazer a arte: você tem que ser preciso, você tem que ser técnico e, ao mesmo tempo, você vai dar vasão às suas emoções, você vai colocar a sua expressividade, você vai colocar as suas emoções. Não é um piloto automático! Se é que se usa esse termo: saia do automático e traz o que você quer. Então, é uma linguagem que permite, uma forma de.. Uma linguagem que permite que eu me comunique com o mundo à minha volta. Claro que de uma forma diferenciada, mas que permite uma comunicação, uma expressão e uma apresentação ao público de quem eu sou.

Pesquisadora - E, aí, pensando ainda dentro desse campo da arte, como você, então, apresentaria a música? Sendo, ela, uma das modalidades artísticas.

E - Como uma das linguagens artísticas, eu diria.. não dá para pensar nela só como uma linguagem, porque ela tem tantos códigos, cálculos e tantas outras coisas que ela tem, como regras, né. E, ao mesmo tempo, tudo aquilo que você tem que transformar e trazer o seu caráter expressivo. Você vai ver que cada construção, mesmo que não tenha uma letra.. é engraçado que 
assim como um quadro que não tem uma figura, você olha pra ele e percebe uma expressividade nele. A música sem texto, sem poema, sem nada, ela fala por si própria. Então, da mesma forma, já como uma linguagem artística, eu poderia dizer que os sons e os silêncios e que eu converso com o mundo à minha volta com os meus sons e meus silêncios, com os meus andamentos, com os meus ritmos. Eu manipulo e eu construo esses elementos, praticamente infinitos, e eu construo uma conversa, e para quem está à minha volta, eu transmito isso.

Pesquisadora - E, dentro da sua experiência de vida e também profissional, e pensando na escola, é, como você percebe a presença da música no processo de musicalização infantil, no processo da educação musical?

E - Tá. Eu vejo a música nesse ponto como um fenômeno transformador. Eu também sou professor da rede pública de São Paulo e a gente vê aqui dentro, citando até, por exemplo, a instituição, onde a gente pode trabalhar, onde a gente faz a música pra valer, você vê uma diferença gritante em relação a uma escola regular, por exemplo. Então, eu vejo a música, quando você entra e permite trabalhar com ela, ela tem uma função transformadora muito grande. Vale lembrar que, assim como toda produção artística, ela pode ter várias finalidades de uso: benéfica e nocivas. Há registros de que na época do nazismo, se usava música como método de tortura. Mas, a gente busca a música como oportunidade de transformação, oportunidade de crescimento, e de entrega, de disciplina. São tantos benefícios que ela traz e que vão ajudar nessa construção do ser humano. Então, ela vem como que uma abertura de portas e mostra pra pessoa o quanto que ela é capaz de se superar, de se apresentar em público, de subir num palco e de se apresentar a uma platéia, um teatro lotado.. Então, assim, uma grande oportunidade de transformação humana. Eu vejo desta forma.

Pesquisadora - Uhum. É, e puxando mais para o contexto da comunidade: você sente essa relação entre os alunos da escola, a comunidade, a escola de música, o processo de musicalização?

E - Olha, bom seria se o Estado tivesse projetos como este. Todos que vêm aqui e até nós, profissionais que, hoje, trabalhamos aqui, que ao chegar em um espaço como este, a surpresa é inevitável. Porque, infelizmente, a gente não encontra trabalhos com o nível e qualidade que temos por aqui. Aparelhos públicos, existem alguns, mas não com a mesma qualidade, com o mesmo cuidado, não com a mesma visão de projeção que a gente desenvolve. Aqui na comunidade existe algumas estruturas próximas, até programas do Governo do Estado, mas é bem raro você ver, assim, projetos que se preocupam mesmo, de verdade, que o aluno venha, que tenha uma transformação. E, assim, todo mundo, todos os educadores querem isso, mas vão até um certo ponto e dali pra frente: 'Oh, meu filho, muito obrigado, pode ir. E, aqui, a gente tem a preocupação de, assim, se apresentou e tudo pro aluno e de repente, ah, e aí ele chegou na adolescência: e aí?1 Ele faz o que da vida? Até nisso. E se ele pretende ser músico mesmo? Porque há um conflito, na verdade: ah, isso é lindo e maravilhoso e tal, mas chegou agora e isso aqui já não é mais lindo, já não é mais maravilhoso, você tem que procurar uma profissão de verdade.. Essas coisas acabam acontecendo. Mas eu, pelo menos, desconheço.. tem poucos, mas é assim, a maioria que, quando você conhece algum, a maioria tem parceria com alguma instituição privada.. De outra forma, aparelhos públicos aqui, próximos, tem alguma coisa mas nada que chegue nesta qualidade. Não tem uma formação para essa formação, para essa transformação toda. E até porque os aparelhos públicos, muitas vezes, depende da troca política. A troca política é o suficiente para destruí-lo. Você entendeu? Esse projeto que eu trabalhei em Mogi das Cruzes, por exemplo, ele existiu por dez anos, um projeto fantástico! E que, depois, que trocou o prefeito, que trocou a secretária, daí, acabou! Você entendeu? E isso, normalmente, acontece. Você vê uma coisa: oh! Que lindo! E, daí, pá, pá, pá: então, trocou. Não continua. Então, assim, Então, 
assim, acho que não se tem uma ideia de continuidade. Os poucos casos.. Eu conheço aparelhos públicos que, de repente, vai, é um exemplo. Ali em Heliópolis, mas aqui na comunidade mesmo, eu desconheço. Nessa região, sinceramente, eu desconheço. Sei da gente!

Pesquisadora - Sim. E outros projetos sociais, você tem algum conhecimento se existe por aqui? E - Outros projetos sociais! Mas não com essa característica! Você entendeu? De formar o músico, de ensinar, de dar estrutura.. A estrutura que se tem aqui é.. de instrumento principal, instrumento complementar, canto, coral, teoria e prática de conjunto.. é uma estrutura que pode sim levar o aluno, se ele quiser, ser um grande profissional de música. Têm alunos aqui que já tá... cê entendeu? Então, sinceramente, neste formato, eu desconheço.

Pesquisadora - Aproveitando a deixa.. é, para melhor conhecer a estrutura do projeto da escola de música, no que se refere ao seu planejamento pedagógico, digamos assim, como vocês pensaram para estruturar e organizar esse projeto com esse formato, tal como você já apresentou?

E - Tá. Olhando na estrutura pedagógica, claro, nós temos as nossas... a gente senta e foi escolhido uma, foi selecionado uma metodologia para orientar e organizar. Pensa-se em um projeto para uma formação musical de três anos. Escolheu-se uma metodologia, a metodologia do Swanwick. Ai, tem lá uma estrutura e, a partir dela, a gente organiza, planejamos neste formato. Daí, têm algumas informações para que, assim, a gente monte lá um cronograma para ser concluído em até três anos, e depois disso, vai, para alguns alunos, acaba ingressando na banda, que já têm alguns alunos que vêm há mais tempo, né, que eles já entraram nessa formação; e os outros, claro, que a gente ainda não concluiu esse processo de três anos ainda, ele ainda está em andamento, está no segundo ano, na verdade, nesta construção.. e, aí, a gente vai programar, a gente vai estudando como seria após o terceiro ano, o que pode acontecer, o que a gente pode fazer de apoio pra eles. Na parte política, aí, precisaria entrar um pouco mais na estrutura da Organização que começou no projeto da ONG e se estendeu para a abertura desta escola de música.

Pesquisadora - Uhum.

E - Na verdade, ele começa na Associação que atende na assistência social para crianças no contraturno escolar, né. Ela começa dentro deste processo. Então, começa dentro desse processo, atendendo a comunidade no contraturno escolar, em eventos. Então, crianças na escola, em horário contrário, vem pra cá.. Mas, a partir daí, surgiu essa ideia de se estender e abrir essa unidade musical. Então, a princípio, atender os alunos em seu horário de contraturno escolar e, claro, nessa segunda situação, atender alunos que não fazem parte desta primeira etapa.

Pesquisadora - Sim, sim.

E - Então, a gente atende também, aqui, pessoas da comunidade que não fazem parte desta primeira etapa. Ouvimos, durante as inscrições, várias pessoas e a gente procura atender a maior demanda possível, né. Mas atendendo mais com o intuito de construir e de dar uma estrutura diferenciada pra eles, né, dentro do conhecimento musical. Não sei se te respondi.

Pesquisadora - É a sua resposta, respondeu sim. Não temos nada direcionado. Ainda puxando o fio desta conversa, pensando a escolha do método, o que levou a escolher este método que não outro? Não sei se tem a ver, mas quais os valores da equipe, do projeto que levou a isso?

E - Há uma consultoria, né. A princípio, foi feita uma análise, foi feita uma consultoria com um músico, o C., que não é brasileiro, que é suíço. Temos esse respaldo, né, muita coisa aqui... nosso próprio presidente, aqui, ele é suíço. Então, nós temos essas parcerias que vêm de fora. $\mathrm{O}$ C. é o nosso consultor junto com a nossa coordenadora, A., que partilhou conosco esta proposta e, a partir daí, foi selecionado um método. Que, claro, ele abrange várias coisas, é, escolher um método é uma coisa complicada, porque muitas vezes, ele foi desenvolvido para um único ponto, 
para um único lugar, para uma única situação, então, a gente buscou por algo que fosse bastante abrangente e que contemple toda a nossa realidade. Então, por exemplo, o método do Swanwick, ele é um músico britânico e que têm vários educadores musicais em grandes universidades aqui no Brasil que trabalham com essa metodologia. Se ele faleceu, faleceu faz pouco tempo, porque eu acho que ele ainda tá vivo. Por exemplo, uma profissional de renome, que estava ainda numa grande universidade e que é especializada neste método, mas acho que ela não está mais lá a continuar seus estudos, é a professora Cecília Cavalieri, da Federal de Belo Horizonte, ela é uma referência internacional. E aí, claro, por ser uma metodologia bastante usada, bastante utilizada nas pós-graduações, nos mestrados e nos doutorados. E, assim, oferece uma estrutura bacana e ampliada pra você poder trabalhar, ela te leva a entender a construção da música, não só tipo: pega e ensaia, vai lendo, sai rezando.. Ninguém merece aquilo! Pega um livro em si, a forma, né. Não. Eu entendo que essa metodologia, ela te leva a entender a parte teórica e a parte prática, pensando não só na construção musical, mas no entendimento da linguagem que é a música. Que é você entender o que é trabalhar com um material sonoro, que é você entender que essa música tem uma forma, que é você entender que ela também tem um caráter expressivo e entender que ela tem um valor pra você. Olha quantas coisas vêm! E ele te proporciona isso. Então, no nosso trabalho, ele vai caminhando dentro deste formato..

Pesquisadora - E isso, também, dentro da perspectiva de que se está trabalhando com o público infantil, em que o processo de compreensão é diferente da do adulto.

E - Exatamente! E que vai até a adolescência, né, porque o nosso público, aqui, vai até os dezessete anos, acho. Então, olha quanta coisa que ele vem, não é só 'oh, pega aqui e toca', ou, então, 'oh, lê essa partitura e toca aqui'. Então, você reproduziu isso, então tá feito! Não, não é por aí.. A nossa aula teórica, muitas vezes, ela é cantada, você entendeu? A aula teórica é registrada, mas ela é bem mais cantada. Outra preocupação que é nossa não é tanto quanto tipo assim: o aluno tirou 8, isso não é interessante. O aluno entendeu? Bem mais que... 'Ah, mas eu tirei quanto?'. 'Sei lá quanto você tirou! Você entendeu isso daqui? Você vai conseguir usar isso daqui na sua prática de conjunto? Isso aqui que você está estudando, você vai conseguir usar quando você for subir no palco?'. A nossa... Pode até ser que a gente pense em nota pra fechar: olha, quanto eu vou atribuir de nota. Mas, você consegue compreender que há uma preocupação de que o aluno realmente compreenda aquilo e saiba usufruir daquelas ferramentas. Muito mais do que você prendê-lo: 'oh, é aqui, e vai..'. Eu passei por esse tipo de estudo, ninguém merece! Não, trabalhamos aqui de forma mais ampla, de modo que leva o aluno a compreender a música. A compreender ela no... manipular seu material sonoro, entender que ela tem uma forma; o material sonoro vem lá desde a escala.. Tudo que é o som, o ritmo, a tonalidade... Mas eu vou entender que essa música tem uma forma, eu consigo envolver essa apreciação, essa formação cultural que desenvolva intérpretes e apreciadores. Que é diferente do 'Ah, põe uma música aí! Ah, eu ouvi. Ah, eu decorei a letra desta música!'. Não! Você entendeu a forma desta música, você consegue compreender esta música, como ela é. E se você tiver que interpretar? E o valor que essa música tem pra você? Então, essa formação musical que não forma tão somente o músico, que pode se tornar um profissional futuramente, ou não, mas que forma um ser humano! Pesquisadora - Uhum. E, aqui, quais são os estilos musicais mais trabalhados aqui na escola? E - Então, a gente não determina um estilo musical, até porque, vou citar como exemplo as minhas aulas de canto, a gente dá uma liberdade para que o aluno use seu estilo musical. A gente apresenta muita coisa, mas há uma liberdade, né. Então, têm alunos que se identificam, vou citar alguns nomes, se identificam a Demi Lovato, ou se identificam com a Evanescence.. O que a gente evita é fica em cima da mesmice. Não! Você está estudando, não dá para ouvir um negócio 
pesado. Mas o estilo, então, o estilo musical na escola, a gente dá liberdade. Quando a gente traz um repertório é porque essa proposta tem um caráter técnico, não é de imposição. É, digo assim, porque eu já passei por isso na minha formação, ví muito isso também, de que na hora de a pessoa fazer um repertório, há uma imposição. Geralmente, o repertório do seu educador. Você entendeu? Então, essa idéia, aqui, a gente não tem, a gente sugere: olha, pesquisa tal coisa. A gente amplia o repertório do aluno, procuramos ampliar. Sugerindo pra ele ampliar: ouça mais coisas. E há outras coisas fora, aí, tem um caráter técnico em cima da música para determinado exercício, para determinada prática, ou para executar um determinado conteúdo. Mas, um estilo fixo, não, a gente abre, tanto que as nossas audições são bem variadas.

Pesquisadora - Para as apresentações que vocês fazem, pensando no trabalho que vocês desenvolvem com as crianças, no coral infantil, como se dá a escolha de repertório?

E - Na verdade, o que você viu no coro infantil, hoje, por exemplo, foi um repasse. Ali foi uma questão de escolha técnica, por que? Porque esse coro infantil se reformulou nesse ano, no início desse ano. Então, aí, vem uma construção de..(inaudível), agora, tá vindo o trabalho dos arranjos a duas vozes. Que o trabalho do arranjo de duas vozes tem que vir com propostas, não é simplesmente 'oh, você faz a segunda, você faz a primeira', não. Então, tem lá a questão da sobreposição da canção, você joga lá uma canção sobre a outra, aí, depois, você põe todo mundo nisso e coloca o discante por cima. Então, ali, você ouve aquela música que está a duas vozes, por exemplo, já faz parte deste processo da construção da habilidade deles cantarem a duas vozes.

Pesquisadora - Legal.

E - Tá. Nosso coro, também, é, assim, o infantil, por exemplo, no ano passado,participou de um evento, de um festival chamado Grand Finale e, mais aí, assim, algumas crianças foram e a maior parte já eram adolescentes, é porque a exigência nesse evento, o coro infantil vai até quinze anos. Eles usam o padrão americano, porque, normalmente, os maestros vêm dos Estados Unidos, entendeu? Então, aí, os coros infantis vão até quinze anos. A gente levou vários adolescentes de até quinze anos. E, aí, assim, esses já cantam mais a duas vozes, a três vozes e, às vezes, até quatro vozes, o nosso coro juvenil, já faz isso. Cantam até quatro vozes. Mas esse coro infantil, esse grupo, por exemplo, ele se reformulou no início deste ano. Então, a maioria é gente nova, e quem vem cantando em uníssono. E, aí, arranjos em duas vozes, mas dentro desta proposta de construção. É uma canção que um canta uma estrofe e depois o outro canta outra, né, daí, têm alguns cânones, porque é isso que a gente vai construindo e o discante: tem uma melodia e tem alguém que está fazendo aquele arranjo por cima, mas em notas mais agudos. Então, ele tá nesse processo de construção. As músicas em inglês vieram, porque eles participaram de um evento com a banda que está fazendo tributo ao ABBA. Então, eles participaram de um evento no Espaço das Américas, né, e vinham as músicas em inglês, como eles já fizeram. Então, na audição que eles vão fazer na escola em novembro, eles vão estar apresentando exatamente as mesmas músicas que eles fizeram. Então, essas duas e mais a outra que veio. Então, faz parte do processo didático de formação do coro infantil mesmo dentro desse processo de divisão vocal.

Pesquisadora - E, a partir da sua experiência com as crianças, assim, as crianças e os adolescentes, quais são os repertórios musicais que elas trazem pra cá?

E - Hoje, lamentavelmente... já mudou muito, mas nos primeiros dias era bem complicado, porque os repertórios que vinham... era sobre tragédia, era o repertório da realidade, nem vou falar que era repertório da realidade deles, é repertório que eles ouvem, que a família ouve.

Pesquisadora - Que era? 
E - Ah, aí, tem o funk num sei lá das quantas; tem o da mulher que saiu com o cara... Músicas muito adultas, na verdade. A mulher que saiu com o cara e que se matou depois. É bem sinistro! Crianças pedindo pra tocar isso! Aí, depois, a história do aborto, aí..

Pesquisadora - Isso em músicas de funk?

E - Não só funk, mas, principalmente, o funk, entendeu. Então, assim, eu diria que isso nem seja o repertório deles. O coro juvenil nem tanto, não veio tanto assim, porque já... até que não insistiram muito pra isso, foram mais tranquilos, mas o coro infantil, o que eles me pediam pra tocar era coisa absurda! De você cair o queixo, de você falar assim: 'meu, como eu vou fazer para sugerir algo diferente?'. E algumas crianças até insistiam e eu quieto. Daí, 'você não vai tocar essa música?'. E eu tentando uma forma de não passar aquela música, porque... porque, 'ah, mas é a realidade', mas essa música não tá muito forte? 'Ah, mas a realidade é essa!'. 'Mas não é essa a realidade das coisas?' Tô falando de crianças de dez anos falando isso!

Pesquisadora - E como você tentou lidar com isso?

E - Eu dizia: 'é uma realidade, mas será que a gente não pode construir uma realidade diferente? Então, se você está vendo tanta coisa ruim, vamos tirar um momento para a gente ver coisas mais bonitas? Basta de sofrimento, se a vida tá tão sofrida, vamos achar um espaço pra gente sofrer menos e tornar a coisa mais divertida?'. E, aí, claro, partir para a seleção de um repertório bem definido, bem direcional, né, e que conquistasse eles pelo prazer de fazer as músicas. Alguns pelo desafio de uma música nova, de uma música em um outro idioma, muitas vezes, em inglês, ou em hebraico, cantos simples que são possíveis de serem feitos. E, aí, aos poucos, ir ganhando essa nova situação. E, hoje, graças a Deus, é possível trazer um repertório diferenciado. Aí, dessas solicitações de música, já não encontrei mais. Eu encontrei muito isso no meu primeiro ano, nos meus primeiros meses aqui. Eu digo meses, porque eu entrei aqui no segundo semestre de 2016. Naquele primeiro momento, encontrei isso muito forte, mas, depois, a gente foi revertendo, foi revertendo aos poucos. Foi difícil no começo, mas depois deu certo. Mas essa é a realidade do que eles vêm trazendo.

Pesquisadora - E, agora, pensando um pouco a parte das dificuldades e possíveis limitações que você vivencia junto com demais educadores dentro do projeto, com as crianças?

E - Você fala de dificuldade deles em relação ao ensino?

Pesquisadora - Nas mais diferentes esferas. Na sua relação com as crianças, como professor; mas também como projeto social que se propõe à educação musical. Enfim, me refiro aos possíveis enfrentamentos da instituição.. Quais são os desafios aqui?

$\mathrm{E}$ - Eu acho que uma das grandes dificuldades, um dilema, na verdade, que a gente encontra bastante, e que é interessante isso, mas observando, também, o outro lado da moeda, por ser professor de escola pública, a gente vê eles trazendo pra cá muitos vícios da escola. Muito. Então, por exemplo, o aluno simplesmente faz o que dá vontade de fazer. 'Ah, eu não fiz', a escola reclama que eles fazem isso.. Então, por exemplo, o professor tá passando alguma coisa e 'ah, eu não trouxe caderno, eu não trouxe lápis, eu não trouxe..' e isso, às vezes, vem pra cá. 'Ah, eu não fiz, porque eu faltei', então, a falta, tipo, os torna livre de ter feito. Você entendeu? É um vício que, infelizmente, perdura dentro da escola pública. Não dá pra se libertar. Isso é uma verdade. E eles fazem o que dá vontade, infelizmente é verdade. Gostaria que fosse diferente, mas essa é a verdade. $E$, às vezes, isso vem pra cá. $E$, então, muitas vezes se encontra alunos participando de uma aula de canto e você pede uma determinada audição: 'olha, tal dia vai ter audição, tá?', 'ah, tá'. Chega no dia: 'você estudou?', 'Ah, não. Mas eu faltei! Se eu faltei, porque eu tinha que ter estudado?'. Não, peraí, 'se você faltou, porque você não procurou saber o que aconteceu?'. Você entendeu? 
Pesquisadora - Uhum.

E - E, assim, é uma posição diferente que a gente tentar fazer aqui. Eu confesso que a gente já conseguiu muita coisa, até porque isso não é uma coisa que a gente transforma da noite para o dia. Dá trabalho! E eu até confesso que a gente conseguiu muita coisa, muita! Muito mesmo! Ainda tem os alunos que simplesmente somem, desaparecem mesmo e, aí, depois, voltam. Aí, é claro, a escola entra em contato pra saber, a direção... ah, tá, às vezes, liga pra família: 'o que tá acontecendo? Por que que não está vindo?'. Daí, se voltar, como é que vai ser, se vai continuar. 'A escola não fechou as portas pra você, é você que não está vindo'. Né?

Pesquisadora - Uhum.

E - Mas a gente conseguiu reverter muita coisa. Mas ainda é uma briga um pouquinho grande. Acho que ela vai um pouquinho mais longe.

Pesquisadora - Uhum. Que é uma questão estrutural, né?

E - Muito grande! Tem, por exemplo, um caso de uma aluna, que tudo o que eu peço, ela simplesmente não faz! E, uma vez eu estava conversando sobre ela e o presidente falou: oh, essa daí, se der uma cesta básica pra ela é quase perigosa a mãe vender a cesta básica e trocar por droga. Entendeu. Então, assim, além da falta de estrutura que boa parte deles têm.. hoje, até que a gente tá com um público mais misturado com essa turma que veio que não era da $\mathrm{ONG}$, mas que veio de fora, coisa e tal. O público tá um pouco mais mesclado, mas ainda tem muita gente nesta situação. Então, a questão da estrutura familiar e esse convívio não foi transformado dentro da escola regular, até porque para a escola regular uma coisa assim não é uma coisa simples, mas que a gente conseguiu, aqui, reverter com muitos esse quadro. Né? Exigir deles um retorno, exigir deles a participação nas aulas, um desenvolvimento bacana e, não só exigir, mas proporcionar também momentos de superação, né: vai lá fazer seu solo! Vai lá fazer suas coisas e tal. É um verdadeiro show, na verdade, né. E, aí, sim, mas tem dificuldade. Acho que a educação em si no Brasil tá muito mal acostumada, está cheia de vícios nesta parte.

Pesquisadora - E isso me faz pensar, dentro da estrutura que eu acabei conhecendo e, de fato, me surpreendi muito positivamente, acaba sendo uma quebra de expectativas, né, pensando, de modo geral, na estrutura de alguns projetos sociais..

E - Sim! Porque projeto social, normalmente, é: ah, vou fazer um projetinho lá. Vou pegar uma fala da nossa direção, da nossa coordenação e tal: escuta (bate com as mãos), as crianças pobres da periferia é bonito ver até certo ponto! Dali pra frente, já não serve mais. Profissionalizar, então?! Você entendeu? Pega umas coisas lá, pega uns instrumentos lá, eles fazem uma batucada: 'ah, é bonito!'. Lindo! Ah, isso é um projeto social! É um projeto social? Bem, aqui, apesar de ser um projeto social, o projeto social cujo resultado se pega em busca pela excelência! Se busca a excelência! A gente tem tocado com músicos de nível bem considerado.

Pesquisadora - E isso acaba sendo um desafio, penso eu.. Tanto pelo que você trouxe sobre a esfera da escola regular, como a esfera familiar, comunitária e como vocês buscam articular essas diferentes referências. O que deve haver possíveis confrontos entre esses mais diferentes ambientes e seus significados.. E, aí, como articular?

E - Pô! Sim! Sim! Exatamente! Ah, por exemplo, vai, nós fomos ao show do Bocelli. Andrea Bocelli, é, Amilton de Lana, o Pipoquinha, recebemos um trio de jazz que veio da Alemanha, fizemos um workshop que está sempre aqui com a gente, o Marco Lobo.. Ah! As nossas crianças cantando com o grupo que cantam com o ABBA hoje, no palco do Espaço das Américas! Então, assim, não é só 'oh, faz lá uma apresentaçãozinha'. Não, peraí! Deve-se ter um mínimo de excelência. Os nossos alunos estavam em canais de empresas de televisão. Mas por quê? Porque não é só mostrar o projeto. 'Ah, olha lá, eu fiz uma música lá com o projeto social, tá lindo!'. É 
uma coisa que eu questiono muito e que eu já ví muitos colegas, infelizmente, partirem para esse lado.. O processo é importante. E muitas vezes, eu vejo assim: ah, mas eu não estou preocupado com o produto, eu só tô de olho no processo. E, muitas vezes, esse estar só de olho no processo é comodismo! Então, muitos projetos sociais se acomodam. Ah, e por quê? Porque ele tira da suas costas uma responsabilidade de ter um resultado de alto nível. Nós fazemos esse processo? Sim! Mas como é que eu vou fazer para que esse aluno chegue lá? Eu preciso de um produto também. E consegue! Entendeu? Então, é isso. A formação também precisa de um resultado. Não é só 'ah, mas ele teve isso'. 'Não tô preocupado com o produto que eu vou mostrar. O importante pra mim é o processo'. Então, muitas vezes, isso é uma forma de se acomodar. Aqui, não. Se preocupa com o processo? Sim. Mas o aluno não vai subir no palco e fazer pra valer.

Pesquisadora - Uhum. E, essa relação diária que você tem com os alunos, você percebe algum impacto neles?

E - Sim. Em vários níveis. É uma realidade, assim, que destoa! Destoa muito! Vou usar a minha comparação de novo: eu cheguei a apresentar com alunos da escola pública em um show que nós fizemos em um teatro. 'Meu, que banda é essa?! Que banda é essa?!'. 'É gente da periferia, meu amigo'. Da periferia, assim como vocês.. Mas por que eles conseguem dar um resultado desse? Entende? 'Oh, olha, quem é essas crianças?!'. 'Gente, galera da periferia'. Entendeu? Galera da periferia. Oh o que eles estão produzindo! Olha o que eles estão fazendo! Então, esse diferencial. E outra: você sente a diferença sim de postura, diferença de comunicação, um querer, um fazer mais. Muda. São outros garotos, são outras garotas. A transformação.. Não vou focar, porque ainda não tá concluído. Mas o que foi trilhado, foi trilhado com louvor. Com certeza.

Pesquisadora - E, acho que para estar encerrando..

E - Eu falo pra caramba, né? (Risos).

Pesquisadora - Não, para mim, isso é importante. Mas, a pergunta que vou fazer agora... é, na sua perspectiva enquanto profissional e que trabalha aqui, você vê alguma relação entre a educação musical e a formação cultural desses alunos?

E - Sim! É, olha, é impossível não ver o resultado. É impossível. Ele é muito claro. A postura que eles assumem, ou quando estão fora, claro, deslizam muitas vezes, nem todo mundo, nem todos entram na mesma linha, isso é um fato. Mas você vê, é perceptível que é um grupo diferenciado. E que estamos, realmente, formando bons apreciadores, pessoas que não só apreciam música, mas apreciam arte como um todo, e que sabem criticar, né. Eu acho que isso é uma conquista. Você formar apreciadores que tenham senso crítico. Que saibam escolher, e a gente tem notado isso sim. E, claro, em uma conjuntura maior, alguns casos com apoio familiar, e isso colabora muito; mas até aqueles com maior estrutura fora, de estrutura mesmo, de convívio familiar mais complicado, ah, a gente nota sim uma grande diferença, uma grande evolução, uma grande conquista, na verdade. A transformação é grande. Isso dai não tem como negar, é muito claro. $\mathrm{E}$ a educação musical, a formação que eles estão recebendo, ela não só está formando músicos... tá formando músicos, porque, hoje, entre naquele dilema, até porque vários aqui que querem ser músico profissional. E de vez em quando, a gente até recebendo pais aqui: 'o que eu faço? Porque meu filho que ser músico'. Nós: 'Ué, deixa!', né?! (Risos). Eu deixei o meu, não foi músico, mas deixei ele ser bailarino, então, tá bom. Ai, eles perguntam: 'Mas e o mercado?'. A gente procura esclarecer: 'Olha, o mercado é possível, o mercado existe, a gente passa as opções..'. E aí? Vai permitir? Então, assim, eu tenho sentido que a música tem conquistado eles, o estudo de música os tem conquistado. A sua formação cultural, isso é inevitável. Ele nos procuram! 'Olha, eu queria..'. Você percebe que eles ouvem coisas mais elaboradas, já sabem selecionar melhor. Então, tem atendido, tem alcançado. Às vezes, não, né, ainda como a gente gostaria que tivesse 
mais... Mas, com certeza, é clara a transformação. A transformação que eles demonstram do seu gosto, crítica, analisar.. é diferente, já mudou bastante.

Pesquisadora - E, para finalizar, se você puder me falar sobre quem são essas crianças e adolescentes que são seus alunos. Já que eu não terei contato direto com eles, eu irei conhecê-los por meio de vocês, educadores, né.

E - São umas figuras. No grupo de violões, são três alunos, quatro, porque uma falta muito, mas com um nível de conhecimento diferenciado, diferente, o grupo é desnivelado, mas que são pessoas que se superam, que gostam de desafios e que, né, já estão nesse processo de transformação. Esse é o grupo de violões que eu tenho. Um trava um pouco mais, porque a primeira opção de instrumento não é aquela, a opção principal dele é o canto, mas naquilo que tem sido colocado, ele vem se desenvolvendo, tem um pouco de medo, às vezes, inseguro, bastante, mas que demonstra assim.. ele é muito esforçado para poder colher o resultado final. A turma de contrabaixo, tem dois garotos que até há pouco tempo não tinham e que sonha ser músicos profissionais, tocam nas suas comunidades religiosas, onde frequentam, mas que sonham com a sua carreira musical. Um, há um mês, sola um pouco mais, mas são pessoas que você vê que respiram música, a música fala forte neles. Os cantores, é bem variado, que é um time bem grandinho, né? Falar geral.. é, são algumas turmas, na verdade. Mas que, eu tenho jogado alguns desafios pra eles, alguns se recolhem, mas têm alguns que se destacam; um ou outro se recolhem um pouco mais, mas quando você solta a bomba, eles, normalmente, nos presenteiam com resultados bem surpreendentes. Ah, os corais, são três. O coro das crianças, ah, teve uma reformulação. Algumas crianças que se destacam, que destoam do todo do grupo, porque parece, ter ainda querer uma atenção especial, chamando muito a atenção pra si com o trabalho do coro, com a visão de palco, com a visão de festival e encontros de coros que tem aquele ensaio pesado, muitos deles oferecem lá alguma resistência e tal, mas é uma construção em processo: o entender que o subir no palco, uma construção de ensaio é uma construção em processo com grandes conquistas já, mas com bastante coisa ainda a melhorar. O coro juvenil vai se superando. E um grupo que, na verdade, um grupo que contempla todos os jovens, dá liberdade para que, praticamente, todos da escola participem. Nem todos vêm, mas é o grupo bem heterogêneo que mais tem entendido o que é construir desafios. E tem nos surpreendido nos ensaios também, uma galera com uma cabeça bem variada, mas que assume a identidade da escola. A escola já é uma identidade pra eles: 'eu pertenço a isso'.

Pesquisadora - Uhum.

E - E as senhoras são uma figuras. (Risos). Mas bem bacana também.

Pesquisadora - Elas são da comunidade também?

E - São. É, dentro daquele formato, que eu comentei: 'Ah, vamos ouvir o coral da terceira idade? Ah! As velhinhas...'. Elas já são críticas! Já se tornaram críticas com isso.

Pesquisadora - Em relação a que?

E - Repertório, qualidade vocal, qualidade de afinação.. se alguém sai queimando largada, sabe? Qualidade musical. Estética musical. O produto foi bem apresentado. Então, elas são super críticas com isso. Já! Entendeu? Porque é uma cara que a gente quer passar, num é porque é um projeto social que vamos fazer de qualquer jeito, não! Vamos fazer bem feito! 'Ah, mas isso daqui é só pra dar prazer'. Ok, coisa bem feita dá prazer.

Pesquisadora - Uhum.

E - Não é porque 'oh, isso aqui tem que ser leve, que é só pra descontrair'. Não, a gente não vai fazer música de qualquer jeito. O que dá prazer é uma arte bonita, bem feita, bem elaborada, ainda que a temática seja triste, porém, bem feita, feita com capricho, né? Isso que chama bem a 
atenção. Eu acho que eu falei do geral. Teoria, eu pego a escola inteira. Ah, faltou a da musicalização. Da parte teórica, eu pego a escola inteira. Né? Então, vai englobar todos os alunos das disciplinas. A turma de musicalização, ela difere bem! É como se eu estivesse em construção ainda deste conceito. Mas se assemelha muito ao que se vê numa escola regular. A parte da caracterização, as características das crianças em termos de comportamento, mas que já mostra uma evolução muito grande. Já tem um diferencial bem bacana já. É isso.

Pesquisadora - É isso.

E - Falo pra caramba! Tenha dó. 


\section{ANEXO E - OBSERVAÇÕES DE CAMPO}

\section{Parte 1 - Cenário}

Da marginal, sentido Interlagos, Parelheiros, seguimos viagem, a cena urbana cotidiana e já acostumada da grande São Paulo: concreto, construções metálicas e vidros, asfalto, carros e mais carros, prédios, aquela algazarra tediosa e ruidosa que tantos já conhecem. Prédios que, aos poucos, vão dando lugar às casas e imóveis comerciais baixos, a paisagem vai ganhando mais árvores em seus contornos e canteiros, e uma atmosfera de cidade de interior. Numa esquina, houve uma batida policial, sirenes e alguns homens encostados a uma grade, expostos à curiosidade passageira daqueles que transitavam por ali em seus carros. Já no distrito de Pedreira, enquanto circundava a represa, a sensação é a de que estávamos em outro lugar que não São Paulo ou, na verdade, é o desconhecimento e distância dos meus olhos que pouco se voltaram, até então, para as extremidades da Zona Sul da cidade. Talvez pela presença junto d'água e das árvores em maior densidade em suas margens, com as casas arejadas e seus quintais, sem os tais arranha-céus, cartão postal da metrópole paulistana. Havia mais árvores, flores, cores, terreiros de candomblé e de umbanda, ruas alargadas, cavalos soltos pastando tranquilamente à beira d'água. $\mathrm{O}$ tumulto e a frenesi de ruídos e transeuntes eram menores naquele momento: meu primeiro estranhamento, ou confronto direto com pressupostos que me acompanhavam até lá.

No retorno das nossas viagens até a escola de música, essa paisagem se rompia bruscamente numa outra: entre uma rua e outra que serpenteiam em diferentes direções, nos deparamos, volta e meia, com ruas largas, casas amplas, árvores e flores; meia volta, de súbito, à frente, uma bricolagem de jornal: ruas estreitas e casinhas espremidas umas às outras, expostas em seus tijolos, num domínio laranja, terra viva. Na primeira vez que voltamos de lá, ao cair novamente às margens da represa, ao olhá-la uma segunda vez, avistei algo além, lá distante, muito longe: as casinhas e mais puxadinhos de alguma favela, mais cor de terra vermelha entre os verdes das copas das árvores à beira d'água. Uma quentura boa e tranqüila, ao menos parecia ter lá de longe, ao mesmo tempo, me apercebi com um canto de medo que não vinha de lá, mas que vinha de mim. Um segundo estranhamento, ao me dar conta disso: aquela imagem, a da favela, me despertava uma imagem sobreposta a ela, a da violência provável, narrada enfaticamente, repetidas vezes, nos telejornais e nas conversas comuns de muitas pessoas (amigos, familiares e conhecidos), muitas das quais, curiosamente, nunca estiveram nem próximas dali ou em qualquer outra comunidade das periferias. Uma reação direta, arco-reflexo. Passei a reproduzi-la, em silêncio, para mim e em mim, a temê-la à distância, pois de perto é que eu não a via, até então.

A instituição, cenário vivo da nossa pesquisa, por sua vez, próxima a um dos braços da represa e, devido a isso, mais próxima das faixas de terrenos arborizados, situa-se em uma rua residencial, com sede em uma casa. Por fora, não se distinguia das demais residências dali, com exceção da placa indicativa do projeto; por dentro, entramos em outro lugar: a escola de música. Como que um lugar secreto, colorido, cheio de música, crianças e jovens, que os que transitavam somente no lado de fora, em suas calçadas, pareciam não suspeitar de nada quanto ao que havia ali dentro. A escola de música, em seus interiores, em seus bastidores, apresentou uma estrutura surpreendente às minhas expectativas: as paredes com pintura nova e trabalhada em detalhes, cômodos bem alocados, com cores radiantes e vibrantes (vermelho, branco, amarelo, azul); telas grandes e coloridas de um expressionismo abstrato à la Pollock, pintadas por seus/uas alunos/as, dispostas como em uma exposição de arte permanente. Também, em alguns lugares, havia fotografias emolduradas de algumas das apresentações e shows da banda dos/as alunos/as da 
escola e pôsteres autografados por cantores/as (brasileiros/as e internacionais) que fizeram algum trabalho em parceria com eles/as. Havia livros de música popular, música instrumental, de folclore brasileiro distribuídos nas estantes e nas mesas - um livro aberto em uma página com uma fotografia de Stevie Wonder ao lado de um cd de Mozart -; havia também partituras, material pedagógico e outros cds ajeitados em pequenas pilhas sobre as mesas e nas salas de aula. Os móveis eram coloridos, de madeira rústica; os utensílios e decoração eram visivelmente novos e modernos. A copa era aconchegante, onde, em todas as vezes em que lá estivemos, sempre tinha um café passado, potes de bolacha de maisena ou de água e sal, pão de mel Panco e algumas frutas a disposição de quem quisesse.

A sensação era agradável, sensação de casa de vó: que acolhe com certa quentura e sem muitas formalidades, com aromas cotidianos, com sons instrumentais e burburinhos. Tudo, ali, parecia orgânico, organizado e limpo. Sensação de que as coisas funcionavam e fluíam por lá. Onde quer que estivéssemos, as portas e janelas encontravam-se abertas, só não quando estivesse acontecendo alguma aula ou ensaio. Dava para ver lá de fora, e de fora, lá dentro. As pessoas transitavam por lá e cá. Tinha ainda um segundo piso, onde ocorrem diversas aulas de música, principalmente, as de coral e de prática de conjunto. Mais aos fundos, um estúdio de música, onde a banda dos/as alunos/as realiza seus ensaios. Este último, por sua vez, surpreendeu nossas expectativas, pois apresentou a estrutura de um estúdio de música profissional muito bem acabado: com isolamento acústico, uma grande diversidade de instrumentos (cordas, sopros, metais, percussão) novos à disposição, painel de controle de som, microfones, fones de ouvido, cabos, pedestais para microfone, monitores de estúdio, etc.

Os sons dos instrumentos, as vozes, risos e conversas despreocupadas ocupavam a escola, a casa inteira. A música se fazia presente nas aulas, em seus espaços formais e, também, espontaneamente em seus interiores. A música revestia, sutil, presente, as entrevistas, entre uma pergunta e outra, enquanto na fala dos/as entrevistados/as participantes, melodias surgiam tímidas, arranhadas, nascentes, desajeitadas, em pequenas partes, pouco harmoniosas, em alguma aula de instrumento ou de prática de conjunto.

Dentre algumas das cenas que pude testemunhar tais sutilezas cotidianas, me prendeu a atenção algumas: um dia, no lado de fora, um aluno dedilhando tranquilamente o seu violão no sofá da sala da recepção. Parecia que estava na sala de sua própria casa, íntimo e à vontade naquele lugar, esperando sua aula começar, próximo a uma porta aberta, onde dava para fora e se via na presença colorida de arbustos e lindas flores vermelhas em contraste com a parede amarela do quintal. No salão central, crianças dispostas em semicírculo, em volta do professor de canto, atentas (quando não, curiosas com a nossa presença) aos seus movimentos de regência maestral, arranjando a tessitura de suas vozes durante uma aula de coral. Mais à frente, na secretaria, além das já conhecidas cores e conteúdos musicais ali dispostos, um enorme cronograma de papel colado à parede, com toda a sequência organizada de atividades da escola de música para o semestre por diferentes cores e legendas; pastas e mais pastas na estante ao lado da mesa da secretária, o cuidado desta com as fichas de presença dos/as alunos/as - que me remeteram, por outro lado, ao sistema de cartão de pontos.

Essa ambientação, tal como descrita, não pode passar despercebida, visto que, frente ao contexto social comunitário onde a escola de música se encontra, ter um projeto de educação musical respaldado por uma estrutura em boas condições materiais, com instrumentos e aparelhagens musicais novos, no mínimo, reverbera no processo de ensino-aprendizagem dessas crianças e jovens, como também, na construção de seu repertório subjetivo e de seu campo 
referencial que transponha a naturalização do sucateamento (e até a ausência) de equipamentos e programas culturais públicos e gratuitos - entre eles, os que envolvem a educação musical.

A partir da descrição deste cenário institucional, articulada com a discussão teórica conceitual proposta anteriormente, pudemos dar continuidade a ela, agora, por meio de uma análise inicial sobre a relação entre as condições que esta instituição educacional provê para se fazer realizar, em seus espaços concretos, sua proposta de educação musical e sobre o que esse cenário pode nos revelar, enquanto dados de observação, quanto às possíveis relações entre educadores/as e seus/uas alunos/as. E, mais especificamente, ao que se refere a como os professores/as, coordenadores/as pedagógicos e dirigentes da escola de música percebem seus/uas alunos/as. O que, por fim, nos levou a pensar em como isso pode afetar e se desdobrar no próprio campo da educação estética musical.

Parte 2 - Prática de Grupo

São Paulo, 28 de Junho de 2018.

Na tarde deste dia, pude acompanhar uma atividade de prática de conjunto, coordenada pelo professor W., que já havia se iniciado quando entrei na sala onde estava sendo realizada. A sala era pequena, havendo, apenas, um teclado, um pequeno tambor duplo, alguns xilofones e um violão, instrumento utilizado pelo professor para conduzir a prática. As crianças presentes deveriam ter entre 8 a 10 anos de idade, havia cinco crianças ao todo (três meninas e dois meninos): uma das meninas estava no teclado, as demais sentadas ao chão, tocando os xilofones, um dos meninos estava com o tambor, também sentado no chão, e o outro encostado à parede, próximo à janela, ele era o vocal naquela atividade. O grupo estava ensaiando uma música escolhida pelas próprias crianças, "Linda Juventude", da banda 14 Bis, para uma apresentação em Julho. As crianças pareciam à vontade com o professor, ficaram um pouco tímidas e curiosas com a minha presença. A prática seguia sem tantas formalidades, com uma relação harmoniosa entre eles, havia proximidade e tranquilidade. Ora ou outra, o professor se voltava especialmente a uma das crianças para corrigi-la e instruí-la e logo em seguida voltava para o arranjo coletivo. Vez em quando, pedia para ensaiar um trecho em especial da música. Simultaneamente, enquanto a prática acontecia, nos momentos quando o professor se voltava a um dos alunos, as outras crianças conversavam entre si sobre assuntos outros e logo depois, quando o professor voltava a tocar a música em seu violão, sem ele mesmo ter que chamar a atenção, elas voltavam para seus instrumentos.

Já mais para o final da atividade, a secretária da escola entrou na sala e chamou uma das alunas, pois ela era uma das aniversariantes do mês e iriam cantar "parabéns" para ela. A intromissão pouco perturbou o grupo, a dinâmica parecia muito orgânica entre as atividades formalizadas do programa da escola e esses burburinhos cotidianos, digamos assim. Depois de um breve tempo, a menina retornou à sala com um embrulho colorido nas mãos, havia ganhado um presente de aniversário, abriu ainda lá, era uma caixa de bombons, ela sorriu. O professor W. ainda fez algumas correções, voltou em algumas partes da música e indicou algumas mudanças e reforços a serem feitos pelo grupo até o dia da apresentação. Finalizou a aula, pedindo às crianças que apenas cantassem todas juntas o refrão da música, ficou bonito, o vocalista, fechava os olhos enquanto cantava, me chamou a atenção. 
Zabelê, Zumbi, Besouro

Vespa fabricando mel

Guardo teu tesouro

Jóia marrom

Raça como nossa côr...

Nossa linda juventude

Página de um livro bom

Canta que te quero

Cais e calor

Claro como o sol raiou

Claro como o sol raiou...

Parte 3 - Coral Infantil

São Paulo, 24 de Outubro de 2018.

Às quartas-feiras, pela manhã, a escola de música inicia suas atividades com a prática do coral infantil e, em seguida, aula de teoria musical com as crianças mais velhas. Neste dia, em especial as crianças estavam ensaiando algumas canções para uma apresentação em data próxima. Havia, naquele dia, um grupo de dezenove crianças, com idades variadas (entre 8 a 15 anos), com a presença predominante de meninas. Dentre as primeiras observações ali constatadas, percebi imediatamente um maior número de crianças negras e pardas, realidade esta contrastante com a da nossa universidade e dos espaços nos quais costumo circular cotidianamente. Querendo ou não, por mais que tenhamos uma compreensão sobre o aspecto étnico-racial dentro da dinâmica sócio-histórica da realidade brasileira, bem como de toda parte ocidental, ao menos, quando nos confrontamos diretamente com a estruturação etnocêntrica, nos é provocado um lugar além da razão lógica: uma aproximação subjetiva e, consequentemente, objetiva quanto à concretude de relações sociais apartadas e estratificadas conforme determinações de valores sociais a elas conferidas. As crianças e jovens negros brasileiros encontram-se, predominantemente, nas bordas periféricas das grandes capitais, nas margens sociais.

Voltando à prática do coral infantil, como constatado também na outra atividade de observação, esta modalidade não é passiva, visto que com a minha chegada, mesmo que silenciosa, marcou uma presença não habitual para aquelas crianças e adolescentes. $\mathrm{O}$ ensaio ficou então entrecortado por olhares curiosos dos alunos e alunas que lá estavam. Identificando, 
também, uma falha tanto minha quanto da equipe que havia autorizado a minha presença: nem eu, nem eles nos organizamos de antemão para consultar tanto o professor quanto os alunos e alunas do coral infantil. Minha presença se fez de forma desavisada e, por consequência, gerou um ligeiro ruído. Apenas o professor de música foi consultado um pouco antes de eu entrar na sala onde estava acontecendo a prática de coral.

Quanto à dinâmica do ensaio, as crianças estavam dispostas em duas filas: as crianças menores na frente, as maiores, ao fundo. Ao mesmo tempo em que os alunos e alunas estavam em uma sequência de tal modo que atendesse a estrutura musical do coral, marcada pela sobreposição de vozes. O professor estava à frente, ora assumindo papel de regente, ora fazendo a marcação das músicas com o uso de uma teclado e ora, com o uso de um violão clássico. O coral estava a ensaiar três músicas para a apresentação, duas delas, músicas em inglês.

Apesar do engajamento expresso do professor durante o ensaio do coral infantil, o grupo de crianças não estava muito coeso e totalmente voltado para a atividade. Algumas das crianças demonstravam pouco ânimo e pouco interesse, houve uma série de momentos de distrações e interrupções em decorrência das chamadas de atenção do professor para que elas voltassem a se envolver na atividade. Durante toda a atividade, houve bocejos, conversas paralelas, sussurros, espirros encenados. Em particular, havia uma menina, que deveria ter cerca de 11 anos de idade, que, naquele dia, demonstrou pouca empolgação com o ensaio, querendo se sentar repetidas vezes e insistia em descer para poder beber água, além de puxar conversa com outros alunos durante o ensaio. O professor, em alguns momentos, demonstrou irritabilidade, mas conseguiu contornar as distrações de seus alunos e alunas. Algumas vezes, ele repetiu que assim como no ensaio, no dia da apresentação, não poderia se sentar quando bem quisesse, que era momento de trabalhar a voz e as canções, pois, se não, se relaxassem, eles não saberiam como fazer no dia da apresentação, por mais que eles achassem que sim, que conseguiriam.

Por outro lado, enquanto cantavam as músicas, os alunos se mostravam muito bem afinados e um diálogo musical harmônico com seu professor. As meninas mais velhas pareciam mais determinadas e envolvidas com o ensaio, e também os meninos mais novos, que, na fileira da frente, também divertiam-se com alguns passinhos combinados entre si.

De maneira geral, pude perceber um processo de formação mais técnico, voltado à afinação das vozes, aos seus arranjos e sobreposições, bem como o cuidado com a harmonia e a parte melódica da música. Além disso, a sensação era a de que estava a se construir uma estrutura musical coletiva para uma música nascente, condições para que ela pudesse se apresentar em sua expressão estética. 